UNITED STATES DEPARTMENT OF THE INTERIOR

Ray Lyman Wilbur, Secretary

GEOLOGICAL SURVEY

W. C. Mendenhall, Director

Professional Paper 171

\title{
GEOLOGY AND ORE DEPOSITS OF THE PIOCHE DISTRICT, NEVADA
}

BY

LEWIS G. WESTGATE

AND

ADOLPH KNOPF

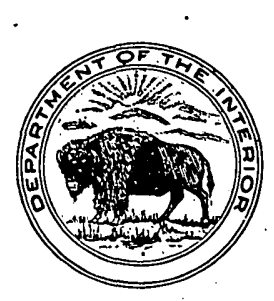

UNITED STATES

GOVERNMENT PRINTING OFFICE

WASHINGTON : 1932 



\section{CONTENTS}

Abstract . 2 .

Part 1. General geology, by Lewis G. Westgate Introduction.

Location

Acknowledgments. .

Bibliography

Physiography

Climate.

Water supply

Vegetation

History

Geology.

Sedimentary formations.

Cambrian system

Lower Cambrian series...

Prospect Mountain quartzite.

Pioche shale

Middle Cambrian series.

Lyndon limestone.

Chisholm shale......

Highland Peak limestone.

Upper Cambrian series.

Mendha limestone...

Ordovician system

Yellow Hill limestone.

Tank Hill limestone-.....

Eureka quartzite.

Ely Springs dolomite

Silurian system.

Devonian system

Silverhorn dolomite and West Range limestone

Carboniferous system.

Mississippian series

Bristol Pass limestone

Peers Spring formation

Scotty Wash quartzite

Mississippian and Pennsylvanian series...

Bailey Spring limestone...

Tertiary system

Pliocene (?) series .

Panaca formation

Quaternary system

Valley alluvium Igneous rocks

Tertiary (?) lavas.

General features....

Condor Canyon section

Black Canyon section

Ely Springs and Delmues Well sections...

Northwestern area

Related dikes.

Intrusive rocks

Quartz monzonite and associated porphyries at Blind Mountain

Quartz monzonite...

Associated dike rocks

Granite porphyry dikes.

Minor occurrences of granitic rock

Lamprophyre.

Diabase of the Ely Range

Page 
Part 1. General geology, by Lewis G. Westgate-Continued.

Geology-Continued.

Contact metamorphism, by Joseph L. Gillson

Blind Mountain area

Limestones

Pioche shale.

Lavas and tuffs

Mixed rocks

Manhattan Gap area

Conclusions

Structure

Thrust faulting

Earlier normal faulting

Later normal faulting.

Brecciation

Part 2. Economic geology, by Adolph Knopf .

General features of the ore deposits.

Oxidation and water level.

Mineralogy

Ore bodies in granite porphyry

Replacement deposits in carbonate rocks.

General features

Fissure veins

Tabular replacement deposits ("bedded ores")

Silver-bearing jasperoid at Silverhorn

Genesis of the ore deposits

Summary and conclusions.

The mines

Combined Metals mine.

History

General geology

Ore bodies.

Pioche Mines Co

Mines on Treasure Hill

Ely Valley mine

No. 10 mine

Poorman mine

Wide Awake mine

Alps mine

rince and Virginia Louise mines.

Location and ownership.

Output.

History

Development

Details of the ore beds and veins

Davidson bed

Big bed.

Twenty-foot bed

Five-foot bed.

Fourteen-foot bed

Silver, Sulphide, and Zinc beds

Fissure veins

Mineral composition of the oxidized bedded ores, by Joseph L. Gillson

Mineralogy of the fissure ore.

Half Moon and Abe Lincoln mines.

Fairview mine

Bristol Silver Mines Co

General features.

Areal geology

bodies of the Bristol mine

General character

May Day vein

Gypsy vein

National mine

Page 
Part 2. Economic geology, by Adolph Knopf-Continued.

The mines-Continued.

Bristol Silver Mines Co.-Continued.

Vesuvius mine.

Inman mine

Tempest mine

Hillside mine $\ldots$

Iron mine

Jackrabbit mine

Pioche-Bristol mine-1.......

Lucky Star mine. . .

Fortuna mine. . .

Manhattan mine

Mendha mine...

Hamburg mine.

Comet mine

Lyndon mine.

Index

\section{ILLUSTRATIONS}

Plate 1. Geologic map of the Pioche district

2. Structure sections of the Pioche district.

3. $A$, Treasure Hill from the northwest; $B$, West face of Highland Range

4. $A$, West face of The Bluffs; $B$, Pioche from Combined Metals mine ...

5. $A$, Erosion surface on lavas north of Condor Canyon; $B$, Upper entrance to Condor Canyon; $C$, Badlands in Panaca formation; $D$, View east across Meadow Valley . .

6. $A, B$, Photomicrographs of endomorphosed quartz monzonite

7. Geologic map of Pioche and vicinity

8. Composite map of mine workings of Bristol mine

Figurs 1. Map of parts of Nevada and Utah showing location of the Pioche district.

2. Production of the Pioche district. .

3. Columnar section of sedimentary rocks in the Pioche district

4. Section of Pioche shale in Lyndon Gulch

5. Section on Dutch John Mountain

6. Columnar section of lavas in Condor Canyon

7. Section of lavas south of Black Canyon

8. Section of lavas east of Ely Springs

9. Section of lavas east of Ely Springs Range

10. Areal geology at the Wide Awake and Alps mines.

11. Section through the Stindt \& Donohue ore shoot

12. Areal geology in the vicinity of the Prince mine

13. Ore shoots in the Mendha vein 



\section{ABSTRACT}

\section{LOOATION AND BURFAOE FEATURES}

The Bristol Range, Highland, and Ely Range quadrangles make up the larger part of a. rectangular area 35 miles north and south by 24 miles east and west, which lies 19 miles west of the Nevada-Utah line and about 250 miles southwest of Salt Lake City. The district lies within the Great Basin, a semiarid region of alternating mountain ranges and intermontane plains floored largely by outwash from the mountains.

The plain, which slopes away from the ranges, stands between 4,700 and 6,000 feet above the sea. The Bristol and Highland Ranges, which are separated only by a low gap, form an almost continuous north-south range that rises about 2,500 feet above the highest part of the surrounding plain, to general altitudes of 8,000 to 9,000 feet, though the highest point, Highland Peak, reaches 9,395 feet. A lower range, the Ely Range, with a northwesterly trend, lies farther east and nearly in touch with the Bristol-Highland Range. The town of Pioche lies midway on the eastern foot of the Ely Range.

\section{ROOKS OF THE PIOOHE REGION}

The rocks of the ranges are Paleozoic sediments, Tertiary (?) lavas and intrusive rocks, and Pliocene (?) tuffs.

The Paleozoic sediments have a total thickness of nearly 18,000 feet. Over 8,000 feet of the Cambrian has been measured without reaching its base. The lowest Cambrian formation is a quartzite, of which only the upper 1,500 feet is exposed, and this is followed by 1,200 feet of shale, 400 feet of limestone, and $\mathbf{1 5 0}$ feet of shale. Above this second shale the upper three-fourths of the Cambrian consists of limestone and dolomitic limestone. It is in the quartzite and in the limestone interbedded in and bounding the shales that the main ore bodies of the district have been found. Above the Cambrian comes 1,795 feet of Ordovician limestone, with some interbedded dolomite and with a 50-foot quartzite a. third of the way down from the top; 75 feet of Silurian dolomite; 3,000 feet of Middle Devonian dolomite with thin interbedded quartzite near the top, followed by 550 feet of Upper Devonian limestone; 3,775 feet of Mississippian limestone with a heavy quartzitic sandstone just below the middle; then, at the top of the series, 700 feet of Pennsylvanian limestone.

The Paleozoic formations are tilted, bent, and faulted, but sharp folding is extremely rare. Dips between $10^{\circ}$ and $30^{\circ}$ are common, but there are few greater than $40^{\circ}$. The rocks are cut by many large and innumerable small normal faults, which in many parts of the area are difficult to recognize because they cut thick formations of similar rocks. A large thrust fault occurs along the west side of the Bristol-Highland Range.

A thick serles of lavas with interbedded tuffs lies along the flanks of the ranges and makes up a large part of the hilly northwest corner of the Bristol quadrangle. The lavas lie unconformably on the Paleozoic sediments and consist mainly of dacite, latite, and andesite, with some basalt and a little rhyolite. About 6,000 feet of lavas and tuffs were measured in Condor Canyon, near the south end of the Ely Range. The age of the lavas is not sharply fixed; they may be early Tertiary or even late Mesozoic. It is not unlikely that they are the result of volcanic action extending over a long period. The lavas are tilted and faulted, though their average dip is less than that of the Paleozoic sediments.

At Blind Mountain, on the west side of the Bristol Range, stocks of quartz monzonite and dikes of similar composition cut an infaulted block consisting of sediments, chiefly Devonian, and lavas. Both the sediments and the lavas are metamorphosed, and a belt of marked metamorphism extends south along the west base of the Bristol-Highland Range for several miles. The quartz porphyry dikes of the region, including those near Pioche, are believed to have come in at the same time.

The plain west of the Bristol-Highland Range is a valley of interior drainage floored with outwash from the mountains, coarser near the range but finer and making a clay flat along the west side of the Bristol Range and Highland quadrangles. The valley east of the Bristol-Highland Range, however, has outside drainage by way of Meadow Valley to the Virgin and Colorado Rivers. The stream in upper Meadow Valley and its tributaries have cut through the surface wash from the mountains and laid bare several hundred feet of white, yellow, and red water-laid Pliocene tuffs that lie in nearly the position in which they were laid down. This erosion has developed a striking badland topography in the Pliocene beds.

\section{HISTORIOAL SUMMARY}

The general succession of events may be summarized as follows :

1. Sedimentation during most of Paleozoic time from Cambrian to Pennsylvanian.

2. Uplift, slight warping, and erosion.

3. Volcanism of perhaps late Mesozoic or early Tertiary time, producing lavas and tuffs. This period of volcanism may have lasted a long time and spanned one or more of the epochs of faulting.

4. Tilting and normal faulting.

5. Thrust faulting.

6. Quartz monzonite intrusions at Blind Mountain.

7. Normal block faulting of the Basin Range type.

8. Erosion of the faulted blocks to maturity and to essentially the topography of to-day.

9. Outbursts of volcanic ash, probably in late Pliocene time, and the deposition of several hundred feet of water-laid tuffs in the valleys.

10. In Meadow Valley, valley cutting, which has produced a badland topography in the soft Pliocene tuffs and canyons where the streams cross the harder Paleozoic limestones.

\section{BCONOMIC GEOLOAY}

The Pioche district during four years in the early seventies was second only to the Comstock district in output of silver. The bonanza ore of those stirring times came from fissure veins in the Prospect Mountain quartzite, of Lower Cambrian age. 
In recent years the main interest has shifted to the bedded replacement deposits of silver-bearing lead-zinc sulphide ore occurring in the limestone members of the Pioche shale-a type of ore body which was discovered accidentally during the prospecting of the fissure veins.

The ore deposits of the district comprise three groups(1) silver-bearing fissure veins in quartzite; (2) silver-bearing mineralized granite porphyry; (3) replacement deposits in limestone and dolomite. All of them appear to have been formed at about the same time, in the epoch of mineralization that occurred shortly after the intrusion of the granitic rocks and their allied dikes of granite porphyry and lamprophyre.

The entire present output of the district is coming from the replacement deposits in limestone and dolomite, but exploratory work is still in progress on the fissure veins and mineralized porphyry.

The replacement deposits include both replacement flssure veins and stratiform ("bedded") replacement deposits.

The replacement fissure veins dip steeply and cut across the bedding of the carbonate rocks in which they are inclosed. They are thoroughly oxidized, as deep at least as 1,100 feet, for on none of them have the mine workings penetrated to water level, and they are highly manganiferous and limonitic and low in silica. At certain horizons stratiform replacement deposits extend out as lateral branches from the fissure veins. Deposits of this kind occur mainly in the Mendha limestone, Highland Peak limestone, and Lyndon limestone. The stratigraphic range is therefore at least 5,500 feet, and as some of the fissure veins extend down through the underlying Pioche shale the indicated range may exceed 6,500 feet. The most notable representatives of the replacement fissure veins are at the Bristol mine, where they yield silver-bearing copper-leadzinc ores. So far unique among the ore bodies of the district is the pipe of wad and pyrolusite ore at the Jackrabbit mine, the periphery of the pipe consisting of a girdle of extraordi- narily coarse white calcite spar produced by the recrystallization of the surrounding limestones.

The stratiform replacement deposits that are attracting most attention occur at the intersections of steep fissures with the limestone members of the Pioche shale. In recent years the "bedded" ore of the Combined Metals mine has been of main interest. The ore is essentially an intimate intergrowth of pyrite, sphalerite, and galena. Although above water level, the ore is unoxidized. It extends on both sides of the mineralizing fissure as far as 100 feet. At the Prince mine ore beds were formed at seven successively higher horizons in the Pioche shale and the overlying Lyndon and Highland Peak limestones. The ore "beds" above water level in the Prince mine are thoroughly oxidized and consist of manganese-iron oxides low in silver, lead, and zinc. About 800,000 tons of ore carrying 2.5 to 3 ounces of silver to the ton, 3 per cent of lead, 35 per cent of iron, and 15 per cent of manganese has been shipped. The Prince mine was in 1915-1918 the premier producer of lead in Nevada. The ore "bed" that occurs here below water level consists of sphalerite, galena, and pyrite in a gangue of manganosiderite and minor quartz. This is the only locality in the district in which the primary source of the abundant oxidized manganese minerals (wad, pyrolusite, and braunite) has so far been found.

Some of the stratiform ore bodies-the ore beds, as they are locally called-were formed adjacent to exceedingly insignificant-looking fissures; and this dependence on inconspicuous mineralizing fissures is beyond doubt one of the most impressive features in the geology of the district. It opens the possibility that there may be many other bedded deposits which, like the Combined Metals ore bed, do not crop out. To find these ore bodies will be difficult, but their discovery will be aided primarily by applying skillfully a knowledge of the geologic column and by determining the faulting that has disturbed or changed the normal sequence of the strata. 


\title{
GEOLOGY AND ORE DEPOSITS OF THE PIOCHE DISTRICT, NEVADA
}

\author{
By Lewis G. Westgate and Adolph Knopf
}

Part 1. General GEOLOGY

By Lewis G. Westgate

\section{INTRODUCTION}

LOCATION

Pioche lies 240 miles southwest of Salt Lake City, in southeastern Nevada, 19 miles west of the Utah. Nevada line. It is the county seat of Lincoln County and is at the end of a branch line 33 miles long. which connects at Caliente with the Los Angeles \& Salt Lake division of the Union Pacific system. The area shown on Figure 1 is covered in part by the topographic maps of the Highland and Bristol Range quadrangles on the scale of 1 inch to the mile. The Ely Range quadrangle, east of the Highland, has been mapped in part only. The following report is an account of the general geology of these three quadrangles and of the economic geology of the mines of the district.

The field work was done in the summers of 1922, 1923, 1924, and 1926. In 1922 Lewis G. Westgate was assisted by Carle H. Dane; in 1923 and 1924 by Joseph L. Gillson. In $1926 \mathrm{~L}$. G. Westgate, assisted by H. Andrew Ireland, completed the field work on the gencral geology and Adolph Knopf worked on the geology of the ore deposits. A brief preliminary report ${ }^{1}$ has been issued.

\section{ACKNOWLEDGMENTS}

It is a pleasure to acknowledge the generous cooperation of mining men and others during the progress of the work, in particular the assistance received from J. H. Buehler, of the Bristol Silver Mines Co.; John Janney, of the Pioche Mines Co.; E. H. Snyder, of the Combined Metals Reduction Co.; H. W. Squires, of the Prince Consolidated Mining Co.; J. B. Wheeler, of Highland; S. F. Whitney, of the Amalgamated Pioche Mines \& Smelter Corporation; Arthur W. Williams, superintendent of the Combined Metals mine; the late H. E. Freudenthal, of Pioche; Victor C. Heikes, of the United States Bureau of Mines, Salt Lake City; and George M. Fowler.

1 Westgate, L. G., and Knopf, Adolph, Geology of Ploche, Nev., and viclnity : $\Delta \mathrm{m}$. Inst. Min. and Met. Eng. Trans., vol. 75, pp. 816-836, 1927.

\section{BIBLIOGRAPHY}

The following list includes the more important works bearing on the geology of the Pioche district:

Aввотr, J. S., The story of Pioche: The Arrowhead (published by the passenger department of the San Pedro, Los Angeles \& Salt Lake Railroad, Los Angeles, Calif.), vol. 4, No. 3, pp. 3-11, July, 1907.

Anderson, J. C., Ore deposits of the Pioche district, Nevada: Eng. and Min. Jour., vol. 113, pp. 279-285, 1922.

Gillson, J. L., Petrography of the Pioche district, Lincoln County, Nev.: U. S. Geol. Survey Prof. Paper 158, pp. 77-86, 1929.

HIr., J. M., Notes on some mining districts in eastern Nevada : U. S. Geol. Survey Bull. 648, pp. 124-137, 1916.

PaCk, F. J., Cambrian fossils from the Pioche Mountains, Nev.: Jour. Geology, vol. 14, pp. 290-302, 1906.

- Geology of Pioche, Nev., and vicinity: School of Mines Quart., vol. 27, Nos. 3 and 4, pp. 2\$1-333, 1906.

RAYmond, R. W., Statistics of mines and mining in the States and Territories west of the Rocky Mountains for 1871 to $\mathbf{1 8 7 5}$.

Spurr, J. E., Descriptive geology of Nevada south of the fortieth parallel and adjacent portions of California: U. S. Geol. Survey Bull. 208, 1903.

- Succession and relation of the lavas in the Great Basin region: Jour. Geology, vol. 8, pp. 621-646, 1900.

STock, CHester, Late Cenozoic mammalian remains from the Meadow Valley region, southeastern Nevada: Geol. Soc. America Bull., vol. 32, p. 146, 1921.

United States Geologroal SuRvey, annual reports in Mineral Resources of the United States.

WaLcoTt, C. D., Cambrian sections of the Cordilleran area: Smithsonian Misc. Coll., vol. 53, 1908.

- Second contribution to the studies on the Cambrian faunas of North America: U. S. Geol. Survey Bull. 30, 1886.

Westgate, L. G., and Knopf, AdolPh, Geology of Pioche, Nev., and vicinity : Am. Inst. Min. and Met. Eng. Trans., vol. 75, pp. 816-836. 1927.

\section{PHYSIOGRAPHY}

The Pioche district lies in the Great Basin, an arid region of islandlike mountain ranges and intermontane plains floored with outwash from the mountains. Most of the ranges have a north-south trend, and one of these extends the full length of the Bristol Range 
and Highland quadrangles. The higher part of this range extends from Bennett Pass on the south to Bristol Pass on the north and is separated by Stampede Gap into two parts-the southern part, known as the
Range. The Highland Range is continued in low hills of similar geologic character from Bennett Pass to Klondike Gap, at the south edge of the Highland quadrangle, and farther south in still higher hills.

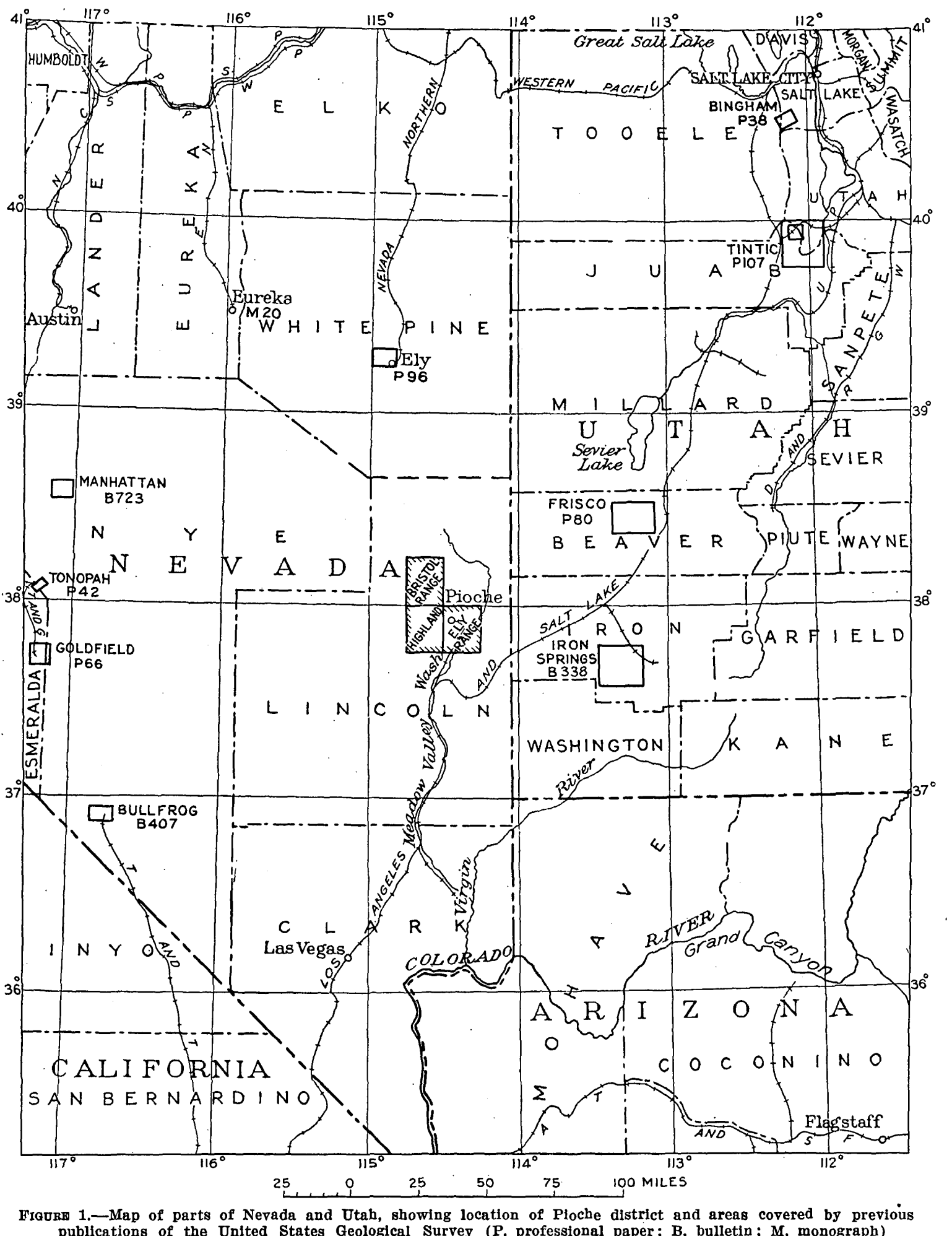

Highland Range (pl. 3, $B$ ), and the northern part, known as the Bristol Range. This double range is topographically and structurally a unit and when so considered will be referred to as the Bristol-Highland

North of Bristol Pass lower and more irregular hills, largely of lava, carry the mountain belt northward beyond the Bristol Range quadrangle. The BristolHighland Range reaches altitudes of 8,000 to 9,000 
feet or more (the highest point, Highland Peak, is 8,395 feet above sea level) and rises about 2,500 feet above the upper edge of the surrounding plain. Pioche lies at the east base of the Ely Range, a lower range which has a northwesterly trend and rises about 1,000 feet above the flat. From its north end, 2 miles east of the main Bristol-Highland Range, it extends 12 miles southeastward, dying out east of Panaca. Two smaller ranges, the Ely Springs and West Ranges, as well as groups of lower hills, lie west of the BristolHighland Range.

The Bristol-Highland Range separates Dry Lake Valley on the west from Meadow Valley and its tributary Lake Valley on the east. Dry Lake Valley is a typical intermontane plain, without drainage to the outside. In its lowest part, along the west side of the Highland quadrangle, it is a clay flat 4,600 feet above the sea and so level that in times of heavy rain it is covered by a thin sheet of slowly moving water. The plain rises toward the range to altitudes between 6,500 and 7,000 feet, and along the west base of the Bristol Range it merges into the alluvial fans that extend out from the larger ravines. The slope of the plain and the coarseness of its material are dependent on the gradient of the temporary streams after they leave the mountains: slopes of 450 feet to the mile $\left(51 / 2^{\circ}\right)$ are reached near the mountain base.

The broad valley east of the Bristol-Highland Range is exceptional in the Basin Range region in having outside drainage. The Meadow Valley Wash and its tributaries, which drain into the Colorado River, have cut in places several hundred feet into the earlier valley filling, which proves to be water-laid Pliocene (?) tuff of the Panaca formation; and the surface falls away in a series of terrace flats to the axes of the valleys. At the north end of the Bristol Range quadrangle Patterson Wash, in Lake Valley, is in a flat 400 feet wide and 30 feet below the adjacent terraces. This inner flat widens and deepens southward to the point where Patterson Wash enters Hamlight Canyon. Side gullies have been deepened to keep pace in downward cutting with the main valley, and the lower parts of the valley are in places rolling hills. The cutting is deepest south of Condor Canyon. Here the inner flat makes the cultivated lands at and below Panaca (pl. 5, D), and back toward the bordering ranges on both sides extensive areas of badland topography have been cut in the Panaca tuffs (pl. 5, $C$ ). These areas consist mainly of the terrace faces, but numerous buttes have been formed by the isolation of parts of the terraces. Along Patterson Wash badlands show in but few places and even where they show are much less prominent than farther south.

The ranges of the Pioche district originated in block faulting of the Basin Range type, with the faults striking in general north and most of the blocks tilted to the east. Subsequent erosion has reduced these blocks to maturity. (See pl. 2.) Along the west side of the Bristol-Highland Range some of the faults follow the west base of the range, but they are now without topographic expression, and the divide has been pushed to the east and follows the middle of the range. The steeper slopes are not at the edge of the range but near the crest, being controlled by the stream gradient. Graded slopes as steep as $25^{\circ}$, thinly veneered with rock débris, are common. Steeper slopes are due to the outcrop of ledge-making or cliff-making beds of harder rock.

The deeply indented border of the rock formations against the wash also proves that erosion has been long at work. There is further an extensive development of bordering rock benches along the base of the range at many places. They are in sharp contrast with the steeper slopes of the range but pass so gently beneath the wash that it is difficult in places to map the boundary of the wash. The benches are developed in part on the limestones but are much wider on the softer lavas.

The rock bench shows on the east side of the lava hills near the north end of the Bristol Range quadrangle, near Wildhorse Bill Spring, where lava flats slightly veneered with alluvium occur in places for more than a mile out from the apparent base of the range. The most extensive rock plains are shown on the lavas east of the Ely Range, from the upper entrance of Hamlight Canyon south to and beyond Panaca. The recent downcutting of the valley fill has left this plain at increasing height above drainage level toward the southeast. The lavas here strike north-northwest and dip $25^{\circ} \mathrm{E}$. Opposite the upper end of Hamlight Canyon the cut surface slopes northeastward at 125 feet to the mile for the $21 / 2$ miles from the base of the range to the railroad. The plain continues south to and beyond Condor Canyon. An observer looking northwest from the south rim of Condor Canyon (pl. 5, $A$ ) sees the near sky line on the lavas as an almost straight line, interrupted here and there by low ridges due to the outcrop of slightly harder flows of lava.

There are no summit flats in the higher parts of the ranges within the district which can be interpreted as parts of former general erosion surfaces or peneplains.

A striking feature of the district is Condor Canyon. followed by the railroad to Caliente. It has been cut through the south end of the Ely Range by Meadow Valley Wash, and its tributary Hamlight Canyon has been cut by Patterson Wash. Both drainage channels leave the broad valley of their upper course and pass through narrow canyons to emerge in the plain at Panaca. Condor Canyon is 5 miles long and about 600 feet deep. The upper entrance is shown in 
Plate 5, B. Patterson Wash enters the hills at a point 4 miles east of Pioche, follows Hamlight Canyon for 6 miles, and enters Condor Canyon midway in its course. Both canyons are the result of superimposed drainage. Formerly the Tertiary filling of the adjacent valleys rose above and covered this part of the range. The drainage took its course on the flat of this upper level regardless of the buried hard-rock topography; but as the streams cut down they reached the buried range, in which they cut the narrow Hamlight and Condor Canyons while working out the broad valleys in the softer Panaca deposits above and below.

\section{CLIMATE}

Pioche is in the semiarid Southwest. Meteorologic records for this district are incomplete and cover a period of only 11 years, ${ }^{2}$ but they are sufficient to give a fairly accurate idea of the climate. The yearly rainfall ranges from 4.7 to 27.4 inches and averages 11.2 inches. The monthly rainfall is almost uniformly distributed through the year, with December and August maxima. The mean annual temperature is $50^{\circ}$; the highest recorded summer temperature is $98^{\circ}$, and the lowest winter temperature $-16^{\circ}$.

\section{WATER SUPPLY}

Pioche, with an annual rainfall of 11.2 inches, is near the desert edge of the semiarid region. The only permanent stream is in Meadow Valley, flowing through Condor Canyon southward to Caliente. This stream supplies the water for the Delmues ranch, at the entrance to the canyon, and for the ranches at and below Panaca. There is no permanent stream in Patterson Wash, east of Pioche.

Springs are few and usually have little flow. The only one in the Ely Range is Warm Owl Spring, at the west base of the range, a mile northeast of Panaca, from which water is piped to the village. It was the complete absence of water at Pioche that forced the location of the early mills near Panaca.

Several springs with good flow issue on the east side of the Highland Range near Highland; from one of these, Floral Spring, water is piped to supply Pioche. The Wheeler ranch, at Highlapa, is the only one of any importance in the district outside of the Panaca region. The Bennett Springs, west of Panaca, furnish a small flow.

The Ely Springs, in the Ely Springs Range, have a good flow. Water is piped from them to a small ranch 2 miles from the base of the range. The springs elsewhere in the Highland and Bristol Range quadrangles have little summer flow and are of value only for

2 Henry, A. J., Climatology: of the United States: U. S. Weather Bureau Bull. Q, p. 924, 1906. sheepmen in the cooler parts of the year. The Bristol mine, before it began to pump water from a well in Lake Valley, was getting water from Pioche by its railway and aerial tram at a cost of 5 cents a gallon.

Water is found in wells in Lake Valley at depths of 20 to 40 feet. Most of the mines of the district do not reach water level. The Bristol mine is dry at the bottom of its 800-foot shaft, whose collar is on the 7,400-foot contour. The Combined Metals mine, at Pioche, does not reach standing water. Water stopped the mining in the old Meadow Valley and Raymond \& Ely mines at the 1,200-foot level. Water is found at an old shaft in the east edge of Pioche at a depth of about 75 feet. At the Virginia Louise water is reached at 496 feet.

\section{VEGETATION}

The valley flats are covered with more or less closely spaced sagebrush, with a scattering of juniper toward the base of the range. In the lowest and driest part of Dry Lake Valley, which is without an outlet, there are small areas of bare clay. Along Meadow Valley, above and especially below Condor Canyon, water is available for irrigation, and good farms are being operated.

Some of the lower hills have little vegetation other than sagebrush, but usually they are dotted with junipers. In the higher parts junipers are abundant and pines and other evergreens come in, and in the mountain valleys there are conifers reaching several feet in diameter. In early days lumber for local use was obtained in part from this source, but there is practically no timber supply in the district to-day.

\section{HISTORY}

The first year for which there is a record of production from the Pioche district is 1869 , when the value of the ore taken out was $\$ 20,000$. Six years before, in 1863, Indians had shown silver ore, which they called "panacare," to William Hamblin, a Mormon missionary. Hamblin visited the place the same year and located the "Panacker" claim. He revisited the region the next spring with others, and on March 18 they organized the Meadow Valley mining district. In May of this year the first settlement of Panaca was made. Indian hostilities in 1865 put a temporary stop to prospecting.

In 1868 F. L. A. Pioche sent in Charles E. Hoffman, a metallurgist, who bought the claims that later became the nucleus of the Meadow Valley Mining Co.'s property and who erected a smelter on the hillside back of the present courthouse site. It is said that bricks for this smelter, brought from Scotland around Cape Horn, cost a dollar apiece. In 1869 another smelter was erected, and ore was sent out on pack animals. Also in 1869 William H. Raymond and 
John Ely came to Pioche and acquired possession of the Burke claim, which was the nucleus of the second of the two great mining companies whose history constitutes the major part of the early history of Pioche. Raymond, with the help of some of the Panaca settlers, brought over from Pahranagat Valley a 5stamp mill and set it up at Bullionville, a mile west of Panaca, where there was abundant water. The stamps of this mill began to drop in February, 1870, on ores hauled down from the Burke mine. In the fall of 1869 the Meadow Valley Co. commenced active operations, and its mill in Dry Valley started in July, 1870. The life of the camp had begun. Pioche was made a post office in that year, and the production for 1870 amounted to more than $\$ 600,000$. In 1871 Pioche was voted the county seat of Lincoln County, and in 1872-73 it had a population of over 6,000 .

(See pl. $4, B$.)

The production chart of the Pioche district (fig. 2) shows two periods of large output. The first began in 1869, reached its peak in 1872, and showed first a rapid and then a slower decline nearly to zero in 1885. Then followed two decades (1885-1905) when the camp was practically dead except for a slight rise of production in 1890-1893. The second period of large output began about 1906 and has continued with marked ups and downs to the present time. The production of the two periods was dependent on different kinds of ores and differences in transportation facilities.

During the first period the main part of the output came from the high-grade silver chloride ores in the fissure veins at Pioche. There was at this time no railway connection with the outside. The Central Pacific, the western part of the first transcontinental line, had been completed on May 10, 1869. The nearest railway point to Pioche was Palisade, 273 miles north on the new line. All mining machinery and supplies had to be brought in and all ore and bullion shipped out by wagon. Under such circumstances only high-grade ores could be worked, and it was important that they should be reduced in the district, by smelting or some other process, to the smallest possible bulk for shipment. The ores were chiefly silver chloride ores, accompanied by lead as carbonate (cerusite) and in much smaller amount as sulphide (galena). They carried in addition considerable gold. Much of the ore ran well over $\$ 100$ a ton, and smaller lots very much higher. One 20-ton shipment of "free" ore sent out by the Meadow Valley Co. in 1870 gave $\$ 500$ a ton and had over 75 per cent of the silver as chloride. The ores were too poor in lead sulphide for smelter treatment, which was tried in the earliest days and proved a failure. They were then handled by the Washoe process, both. wet and dry. Water was lacking near Pioche, and the mills, to get water, were built in Meadow Valley. The first mill was the original Pioneer 5-stamp mill, set up by Raymond \& Ely at Bullionville, near Panaca, 10 miles south of Pioche. This mill was successful from the start. It was enlarged and other mills added until 85 stamps were in operation here. The mill of the Meadow Valley Co. in Dry Valley, about 2 miles north of the entrance to Condor Canyon, was a 30-stamp mill. The ore was at first hauled by wagon from Pioche to Bullionville at a cost of $\$ 5$ a ton. To cut this cost a narrow-gage railway, 18 miles long, was built from Pioche to Bullionville by way of Condor Canyon and completed by 1873 . This line went within a mile of the Meadow Valley

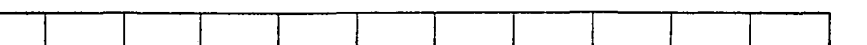


At the same time that the fissure veins at Pioche were being worked the outlying districts were being explored. Mining was going on in the Highland district, at Stampede Gap, and on the west side of Arizona Peak (Mendha mine). More extensive development was undertaken in the Bristol and Jackrabbit districts, near the north end of the Bristol Range, 14 miles northwest of Pioche. Sixty locations were made at Bristol in 1871, and the Bristol district was organized. The ores were oxidized ores in fissure veins carrying lead and silver and some copper and gold. As early as 1872 a reverberatory furnace was erected at Bristol Well, 4 miles from the Bristol mines, to treat the Bristol ores. This was changed to a waterjacket furnace in 1878 and ran for a long time very successfully on the ores of the district and the Mendha mine. In the early eighties a Washoe process mill was erected here to treat the Mayflower ore from Bristol. This also ran successfully for a considerable period. About 1890 another smelter was built to treat copper ores, which are abundant and of high grade in some of the properties. $^{8}$

The ores were concentrated at a mill at the mines and then taken to the smelter. No copper was recovered. The iron ores from Stampede Gap and the Mendha mine were used as fluxing ores. At this time Bristol Well had a population of 400 and a post office. The Jackrabbit district was organized in 1876, and the Day or Jackrabbit mine became a large producer for a few years. The Pioche-Pacific narrow-gage railroad from Pioche to the Jackrabbit mine was completed in 1890.

The Bristol and Jackrabbit districts continued production for a number of years after the practical cessation of work at Pioche.

The Comet mine, 2 miles west of Highland Peak, was located in 1882 and produced small shipments of ores at a later period (1913-1920).

The second period of large activity began in 1905 and has continued with marked ups and downs to the present time. The production during this period has been derived mainly from low-grade silver-lead ores, carrying smaller amounts of gold, copper, and sometimes manganese, which occur as replacement deposits of limestone beds at several horizons in the Cambrian Highland Peak formation. Since 1912 much the larger part of the output has come from the Prince and Virginia Louise mines, but the Combined Metals mine and the Bristol district have helped.

Railway connection with the outside made possible this later period of production of low-grade ores. The San Pedro, Los Angeles \& Salt Lake Railway was being built from Salt Lake City southwest, and ore was hauled as far as Juab, Utah, on this line.

${ }^{3}$ Ahbott, J. W., The Arrowhead, vol. 4, July, 1907, p. 10.
An early attempt to connect Pioche with the main line at Caliente was interrupted by the panic of 1893 , and it was only in 1907 that the present branch line, 33 miles in length, was built. The standard-gage track, 9 miles long, connecting the Prince mine with Pioche, was built in 1912 .

\section{GEOLOGY}

\section{SEDIMENTARY FORMATIONS}

A series of Paleozoic sediments reaching a total thickness between 17,000 and 18,000 feet is exposed in the Pioche district. (See fig. 3.) About 200 miles to the southeast, in the Grand Canyon, the total Paleozoic section is only 4,000 feet thick. Longwell ${ }^{4}$ has drawn attention to the thickening of these Paleozoic sediments westward from the Grand Canyon to southern Nevada, which in Paleozoic time was a geosyncline. In a more northerly part of this geosyncline the sediments of the Pioche district were laid down.

No Mesozoic sediments are found near Pioche, and the only Tertiary sediments are the tuffs associated with the Tertiary (?) lavas and the water-laid tuffs of the Panaca formation (Pliocene?).

\section{CAMBRIAN SYSTEM}

Cambrian rocks cover a greater area than all the other Paleozoic rocks taken together. They make up almost the whole of the Bristol Range south of the Bristol mine, the whole of the Highland Range, and the whole of the Ely Range. Cambrian rocks occur also in the smaller outlying ranges in the southwestern part of the Highland quadrangle. The larger mines of the district are all in the Cambrian. The total thickness of the Cambrian formations is about 8,650 feet. (See fig. 3.)

\section{LOWER CAMBRIAN SERIES}

PROSPECT MOUNTAIN QUARTZITE

Name and distribution.-The lowest formation of the Cambrian is a light to dark red vitreous sandstone or quartzite which is correlated with the Prospect Mountain quartzite of the Eureka district. ${ }^{5}$ It was from veins in this quartzite at Pioche, especially on the Raymond \& Ely and Meadow Valley properties, that the larger part of the earlier production of the camp came.

The largest single area of the quartzite, that in the Ely Range, is a belt that crosses the range obliquely. It makes the low hills along the northeast base of the range for $3 \frac{1}{2}$ miles northwest of Pioche. The promi-

4 Longwell, C. R., Structural studies in southern Nevada and western Arizona : Geol. Soc. America Bull., vol. 37, pp. 555 557, 1926.

${ }^{5}$ Hague, Arnold, Geology of the Eureka district, Nevada: U. S. Geol. Survey Mon. 22, p. 35, 1892. 
nent hills immediately northwest of Pioche and Treasure Hill, just south of it, are in the quartzite. The belt widens southeast of Pioche to a maximum of $11 / 2$ miles and makes the main part of the range for 5 miles, disappearing about a mile south of the Pioche-Panaca road. South of this locality the range is limestone. In the Ely Range the quartzite is generally separated from the other Cambrian formations by fault contacts.

The next largest area of the quartzite is along the west base of the Bristol-Highland Range, where it lies in normal position beneath the Pioche shale. The northernmost area, north of Blind Mountain Spring, is cut out by faults on the northwest and south. In the Highland Range the quartzite is exposed for 2 miles in the vicinity of the Comet mine and again near the south edge of the Highland quadrangle near Klondike Gap. A small exposure of the quartzite lies at the west base of the small range known as The Bluffs, just west of the Black Canyon Range.

Petrography.-The fresh quartzite ranges from white through buff to red; the weathered rock from light to dark red. With the hand lens sand grains are usually visible, but the rock breaks through the grains. Under the microscope rounded detrital quartz grains from 0.05 to 0.5 millimeter in size are seen to be cemented by quartz, which commonly occurs as a secondary enlargement of the detrital grains. Difference in size of quartz grain produces a lamination on joint faces, and crossbedding is not uncommon. At many places lines of coarse sand or small pebbles are seen. The largest pebbles noted were an inch in diameter. No other minerals than quartz are present in the thicker beds, but some of the quartzite is micaceous, and in places there are within the main mass of the formation layers that resemble the overlying micaceous Pioche shale.
The bedding of the quartzite is everywhere distinct and in places prominent. In the outcrop the beds

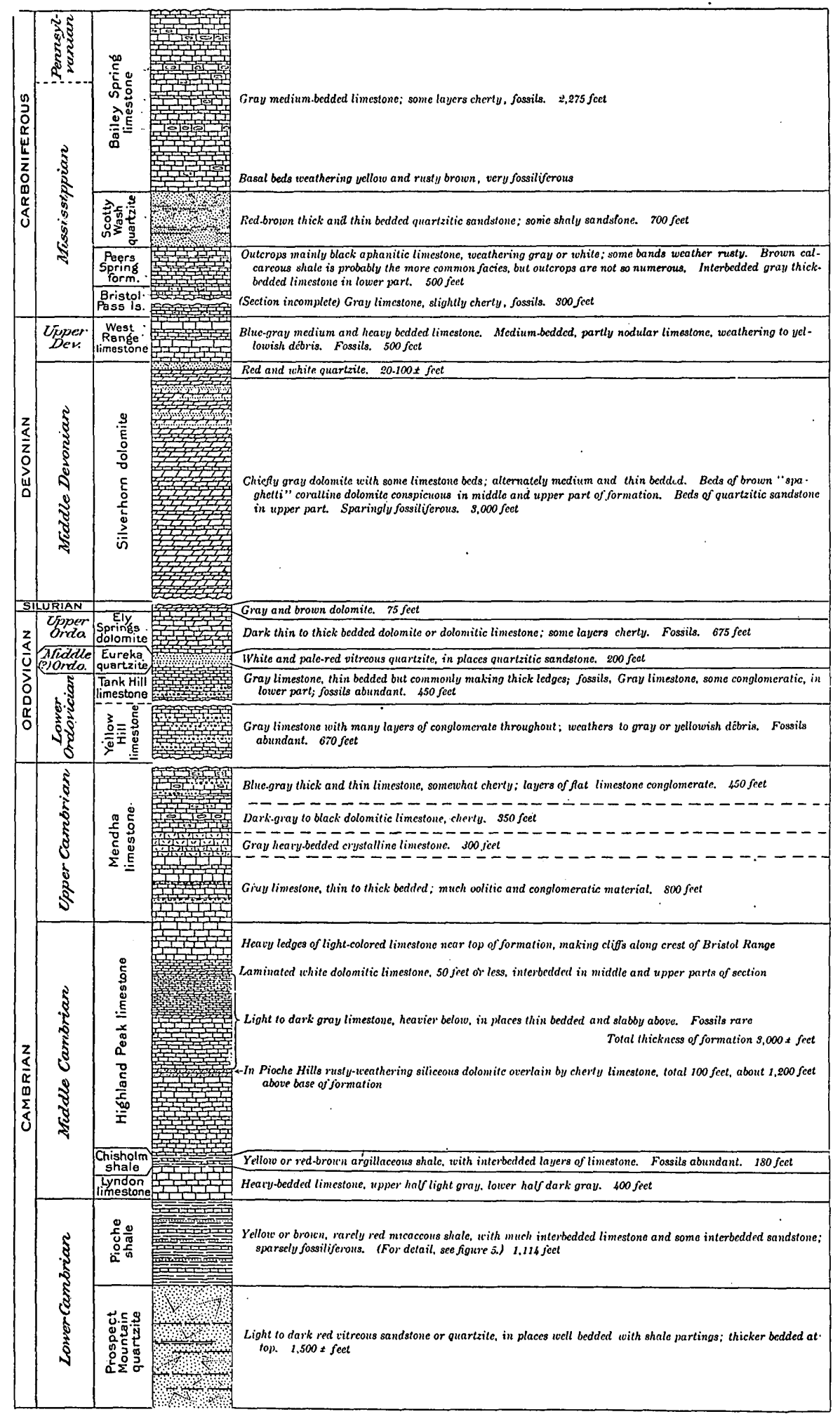

Figdrb 3.-Columnar section of sedimentary rocks in the Pioche district. Breaks in section indicate that the sequence is interrupted by faulting range from less than 1 foot to 4 or 5 feet in thickness. Partings of thin-bedded and more micaceous quartzite are present locally and bring out the bedding more 
GEOLOGY AND ORE DEPOSITS OF THE PIOCHE DISTRICT, NEVADA

distinctly. The beds about Pioche are near the upper part of the formation and are unusually thick bedded. Farther south, along the Pioche Hills, the quartzite is thinner bedded and breaks into flatter débris. It probably represents a lower horizon in the formation.

The micaceous quartzite that occurs in the Prospect Mountain quartzite as partings and in places as layers a foot or two in thickness resembles the Pioche shale. It can be explained as a forerunner of the Pioche type of sedimentation. At the Comet mine the main mass of the quartzite is overlain by 25 feet of shale of Pioche type, and this in turn by about 10 feet of quartzite; then comes the main mass of Pioche shale: The passage from the Prospect Mountain quartzite to the Pioche shale is thus seen to be effected by interbedding. Usually there is little difficulty in drawing the boundary between the two formations in mapping; but in places it is difficult to decide whether the rock is quartzitic Pioche shale or shaly Prospect Mountain quartzite.

Age.-No fossils have been found in the quartzite. As the conformably overlying shale is fossiliferous and has been assigned to the Lower Cambrian, the Prospect Mountain quartzite is regarded as Lower Cambrian also.

Thickness.-The bottom of the Prospect Mountain quartzite is nowhere seen at the surface, nor has it been reached in mining. The absence of sections known to be unfaulted makes direct measurement of the thickness of the formation exposed at the surface impossible. Mining on the Raymond \& Ely vein at Pioche starts in the quartzite at an unknown distance, probably several hundred feet, below the top of the formation. At the 1,400-foot level it is still in the quartzite. Calculation based on dip and width of outcrop southeast of Pioche gives an apparent thickness of about 2,000 feet, but this is an approximation and ignores known but unmeasurable faulting. In the House Range, Utah, ${ }^{\circ}$ the Prospect Mountain quartzite, with which the quartzite at Pioche has been correlated by Walcott, has a thickness of over 1,375 feet, but as its base is concealed, its actual thickness is unknown. In the Tintic district, Utah, ${ }^{7}$ the Tintic quartzite is the lowest known member of the Cambrian and is probably the equivalent of the Prospect Mountain quartzite of Pioche. Its exposed thickness is 6,000 feet, but its base does not show, and it may include some preCambrian beds.

The thickness of the exposed Prospect Mountain quartzite in the Pioche district is somewhat arbitrarily put at 1,500 feet, with the belief that the total thickness of the formation is probably much greater.

- Walcott, C. D., Cambrian sectlons of the Cordilleran area : Smithsonian Misc. Coll., vol. 53, p. 184, 1908.

${ }^{7}$ Lindgren, Waldemar, and Loughlin, G. F., Geology and ore deposits of the Tintic mining district, Utah: U. S. Geol. Survey Prof. Paper 107, p. 24, 1919.

\section{PIOCHE SHALE}

Name and distribution.-The Pioche shale overlies the Prospect Mountain quartzite and comprises about 1,120 feet of shales and thin interbedded limestones. Walcott ${ }^{8}$ described as the Pioche formation certain "arenaceous and argillaceous shaly layers with some thin layers and bands of limestone more or less irregularly interbedded and limited in horizontal distribution, * * * southeast [west?] of Pioche, Nev., on the road to Panaca, Utah [Nevada?]." These are doubtless the shales which are well shown at and west of the pass south of Pioche, along the old road (not the present road) to Panaca. Earlier ${ }^{9}$ he had described a section on the west side of the Highland Range that includes 23 members, of which Nos. 2 to 19 belong in the Pioche shale.

The largest and best exposure of the Pioche shale is along the west base of the Bristol-Highland Range, beginning 2 miles south of the Bristol mine and extending, with one break of 3 miles south of Blind Mountain, to a point $31 / 2$ miles south of the Comet mine, a total distance of nearly 15 miles. Through most of this distance the shale has its normal position between the Prospect Mountain quartzite and the overlying Lyndon limestone. The beds dip at low angles east into the range; and the continued regularity of shale slopes and limestone cliffs is exceptional in a district where the relations of the formations are commonly obscured by faulting. Farther south the shale reappears near Bennett Pass, in the same general position in the west base of the range, and extends to the south edge of the Highland quadrangle. A small belt is found on the west side of The Bluffs, west of Black Canyon.

In the Ely Range the shale occurs in two belts. One can be traced from the northwest end of the range along its northeast side to Pioche. This belt crosses the range at the gap just above Pioche and is cut out by faulting within half a mile southeast of the gap. The Combined Metals mine, at Pioche, is working replacement deposits in the interbedded limestones in this shale. The more micaceous and quartzose variety of the rock has been quarried to a slight extent at Pioche, and in buildings dating back to the early days of the camp it has withstood weathering well. A second belt can be followed along the east side of the middle section of the Ely Range for 4 miles south from the Alps mine. This belt also crosses the range, and the valley made along it is followed by the road to Panaca. Isolated areas of Pioche shale occur at the Prince mine and at a point $11 / 2$ miles north. With the exception of the northern 2 miles of the range, all the areas of Pioche shale in

${ }^{8}$ Walcott, C. D., Nomenclature of some Cambrian cordilleran sections: Smithsonian Misc. Coll., vol. 53, p. 11, 1908.

${ }^{9}$ Walcott, C.. D., Second contribution to the studies on the Cambrian faunas of North America: U. S. Geol. Survey Bull. 30, pp. 33-34, 1886. 


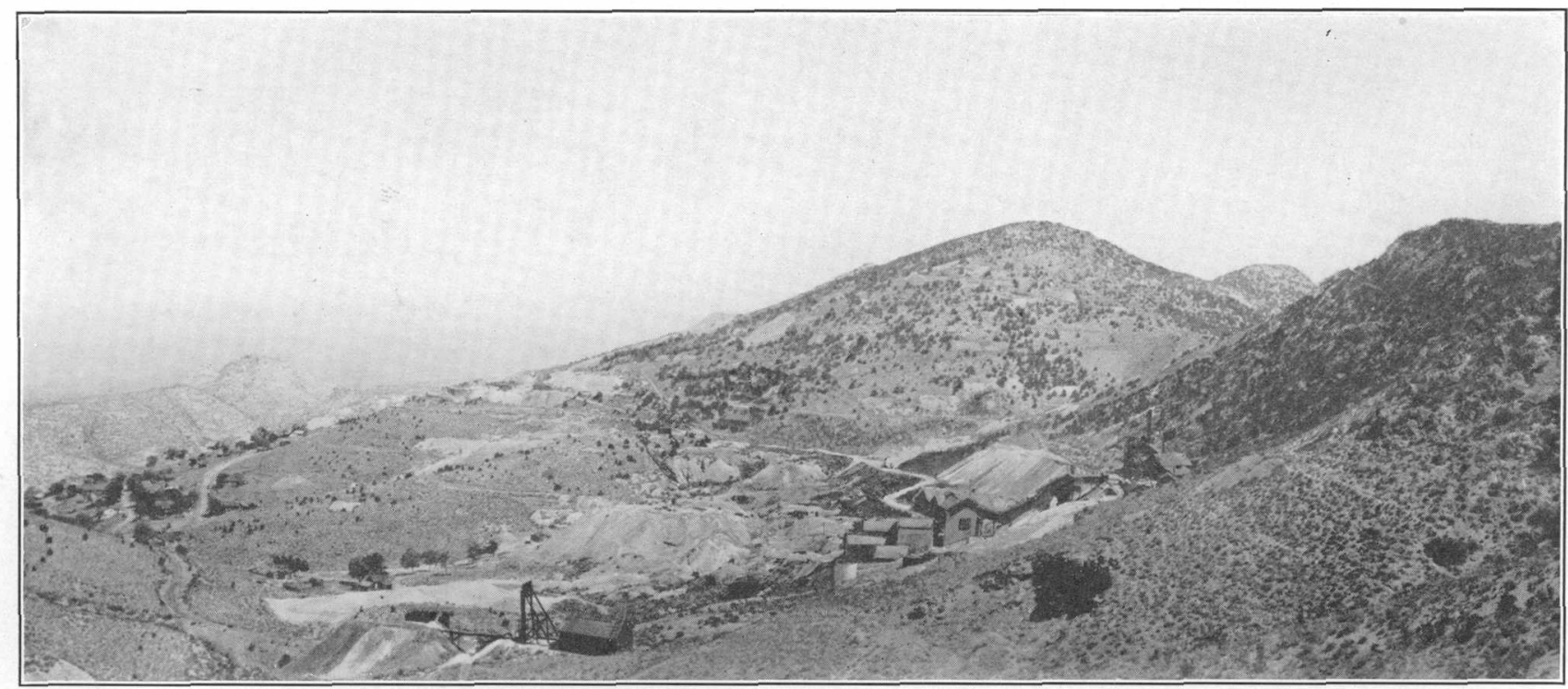

A. TREASURE HILL FROM THE NORTHWEST

Combined Metals mine in the right foreground. Dumps along old fissure vein on lower slope of Treasure Hill in background. Pioche on extreme left, with Panaca road going through the saddle.

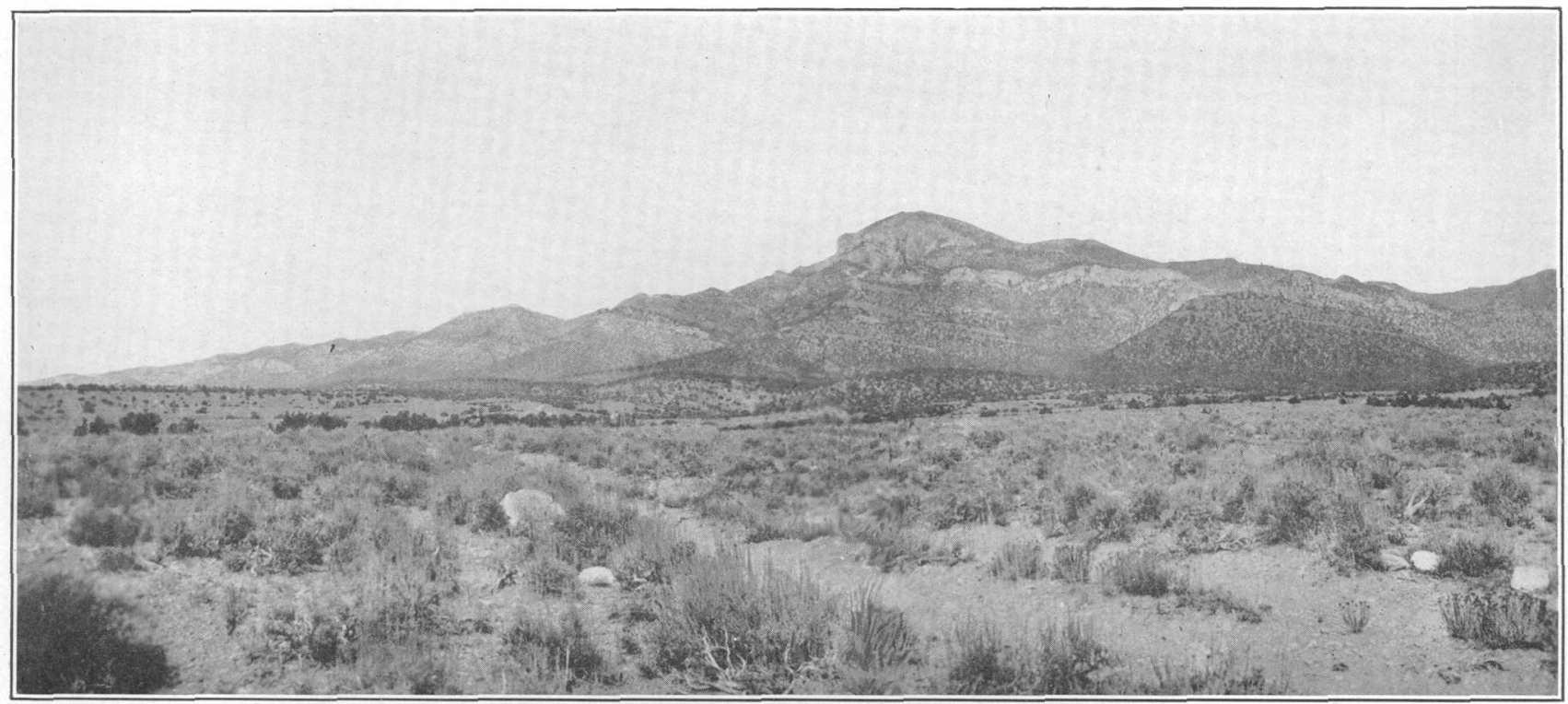

B. WEST FACE OF HIGHLAND RANGE FROM THE SOUTHWEST Highest point is Highland Peak. Lowest slopes are Pioche shale; above that Lyndon and Highland Peak limestones to summit. The Chisholm shale bench
does not show. 


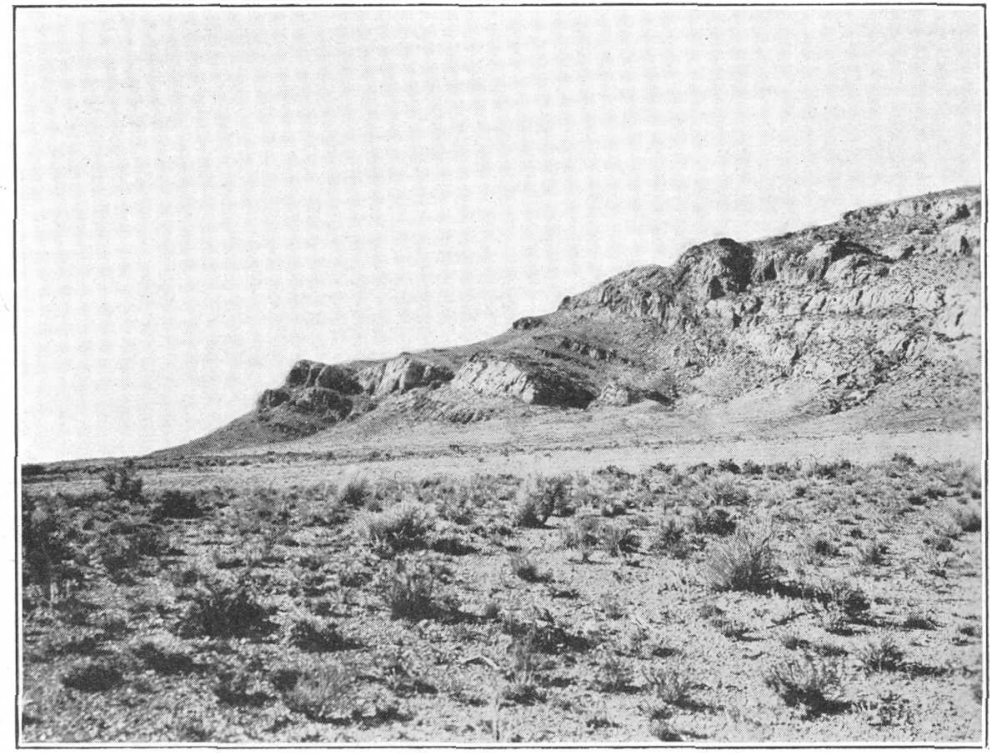

A. WEST FACE OF THE BLUFFS, HIGHLAND QUADRANGLE, FROM THE SOUTH

Lower massive ledges are Lyndon limestone; the gentle slope below, Pioche shale; the terrace above, in the center of the view, the Chisholm shale. Heavier upper beds to Highland Peak limestone. Interbedded limestones show in Chisholm shale and (faintly) in Pioche shale.

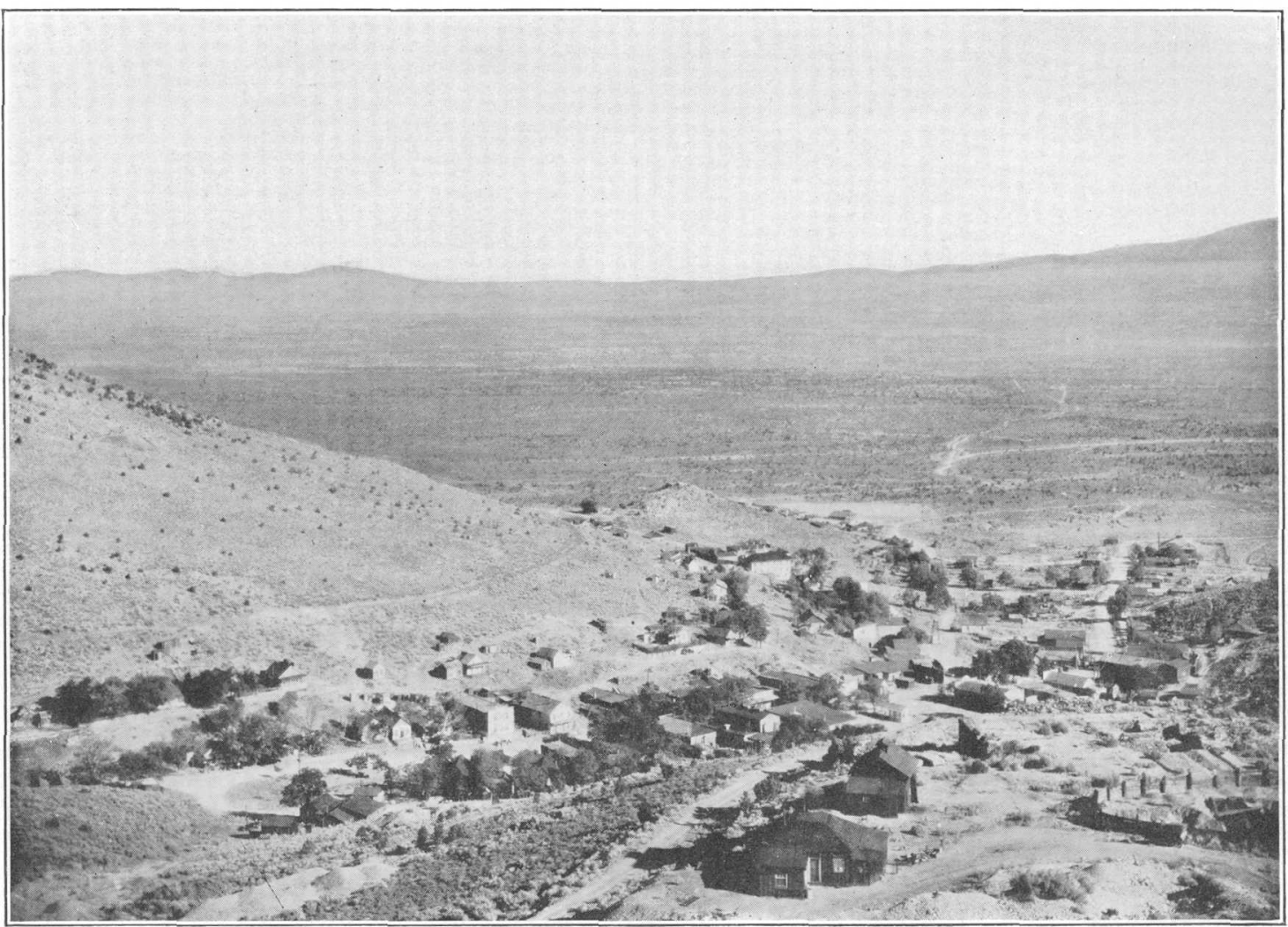

B. PIOCHE FROM COMBINED METALS MINE 


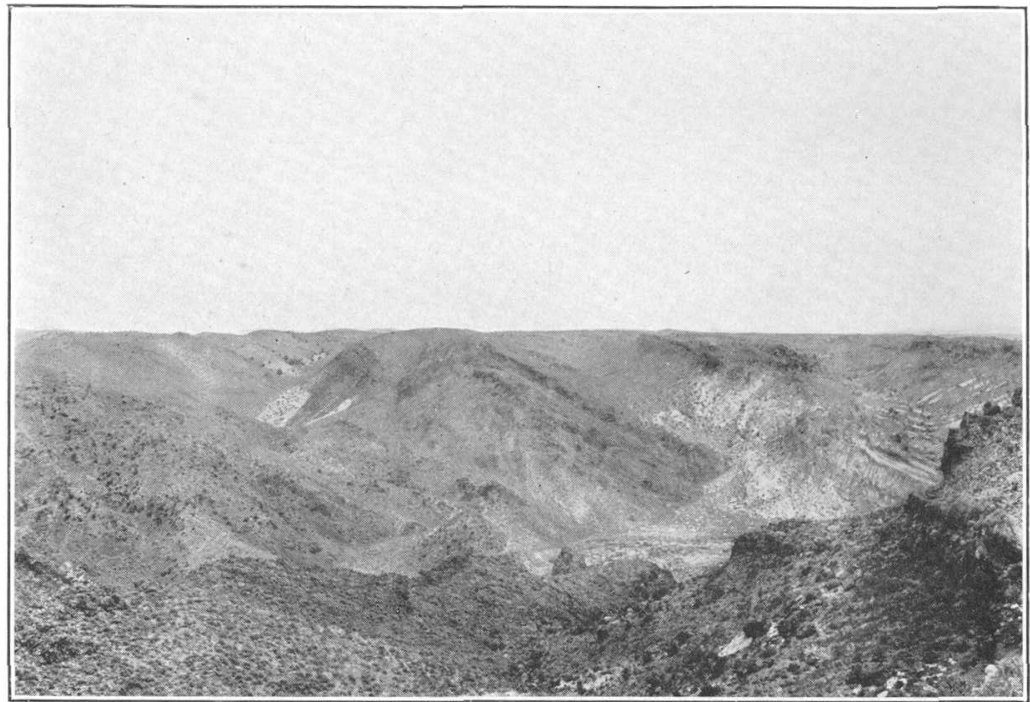

A. EROSION SURFACE ON LAVAS NORTH OF CONDOR CANYON View taken from south crest of the canyon, looking north. Even sky line is the dissected bench

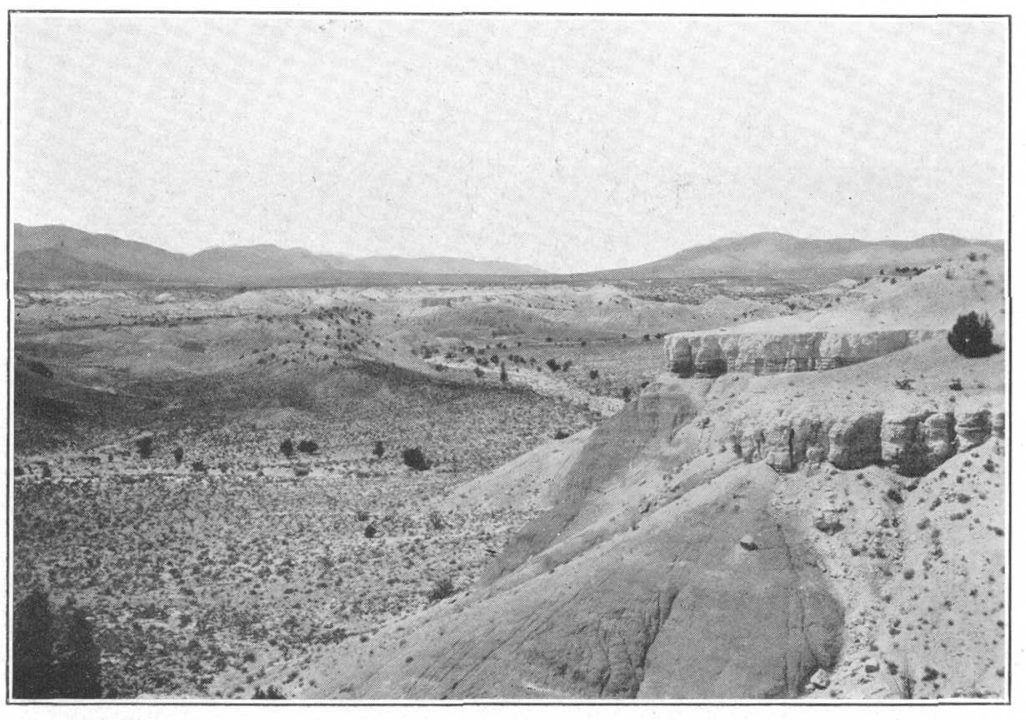

C. BADLANDS IN PANACA FORMATION

In valley west of Pioche-Panaca road, west from Condor Canyon, looking north. Ely Range

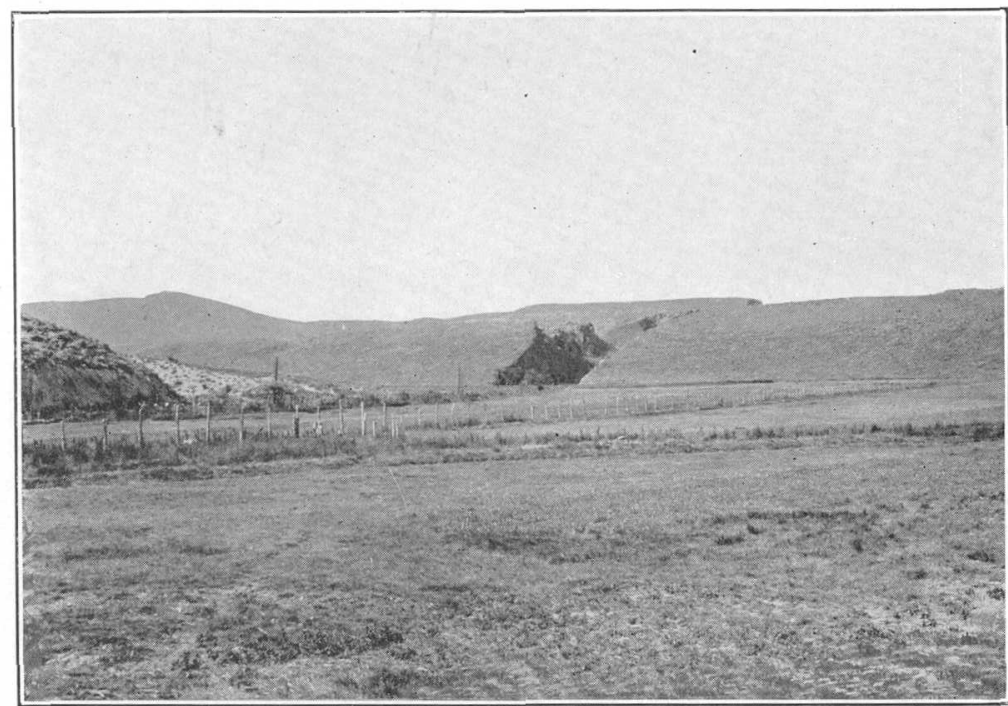

B. UPPER ENTRANCE TO CONDOR CANYON FROM THE NORTHEAST Ridge is composed of lavas dipping $25^{\circ}$ toward the observer. The Pliocene (?) beds (Panaca
formation) originally filled the valley in the foreground and rose above the ridge through
which the canyon is cut, but perhaps not above the highest hill on the left. A superimposed course.

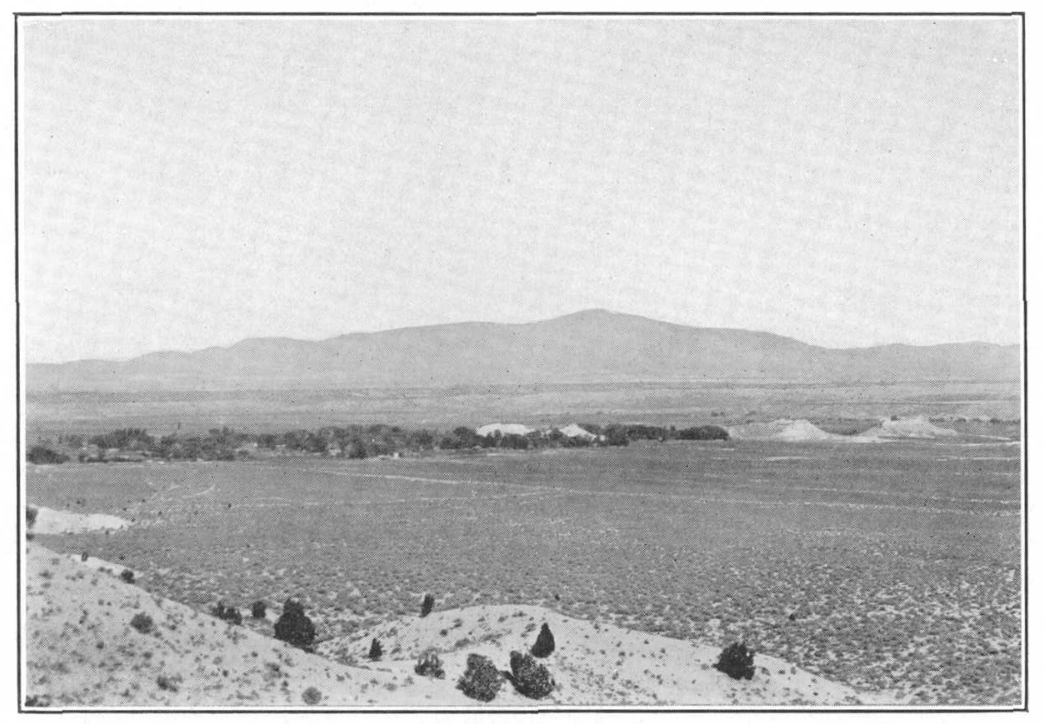

D. VIEW EAST ACROSS MEADOW VALLEY

Village of Panaca, with white buttes of Panaca formation, in middle ground; Highland Range 


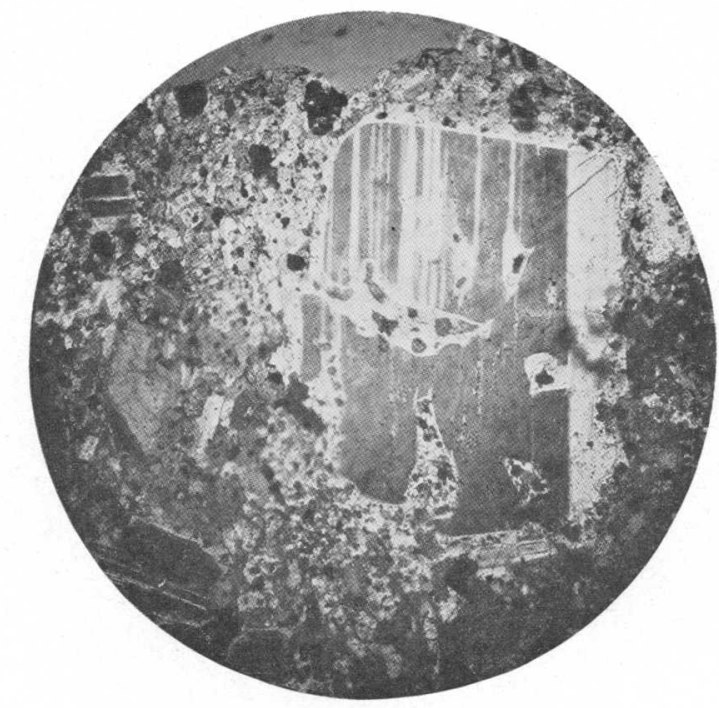

A. PHOTOMICROGRAPH OF ENDOMORPHOSED OUARTZ MONZONITE

Crossed nicols. Shows wedges of andesine and orthoclase in plagioclase and the small pyroxene crystals which followed the secondary feldspar. Enlarged 40 diameters.

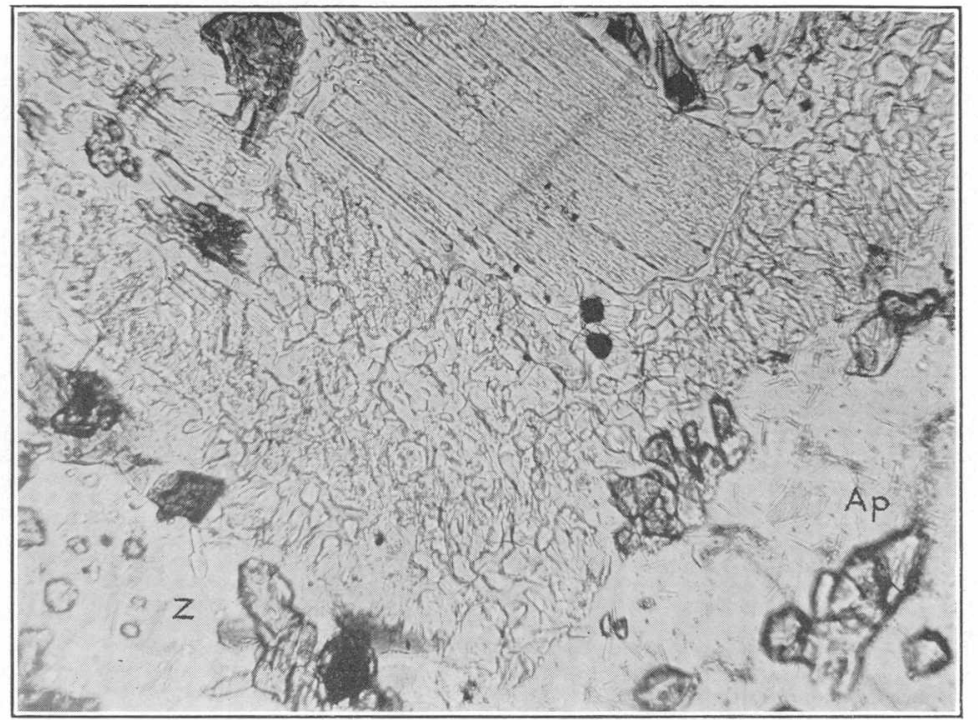

B. PHOTOMICROGRAPH OF ENDOMORPHOSED OUARTZ MONZONITE

Plane polarized light. Shows graphic texture at edge of a plagioclase grain due to its partial replacement by potash feldspar. Several of the small anhedral grains of augite, minute needles of apatite (Ap), and zircon grains $(\mathrm{Z})$, characteristic of this metamor
phism, are seen. Enlarged 200 diameters. 


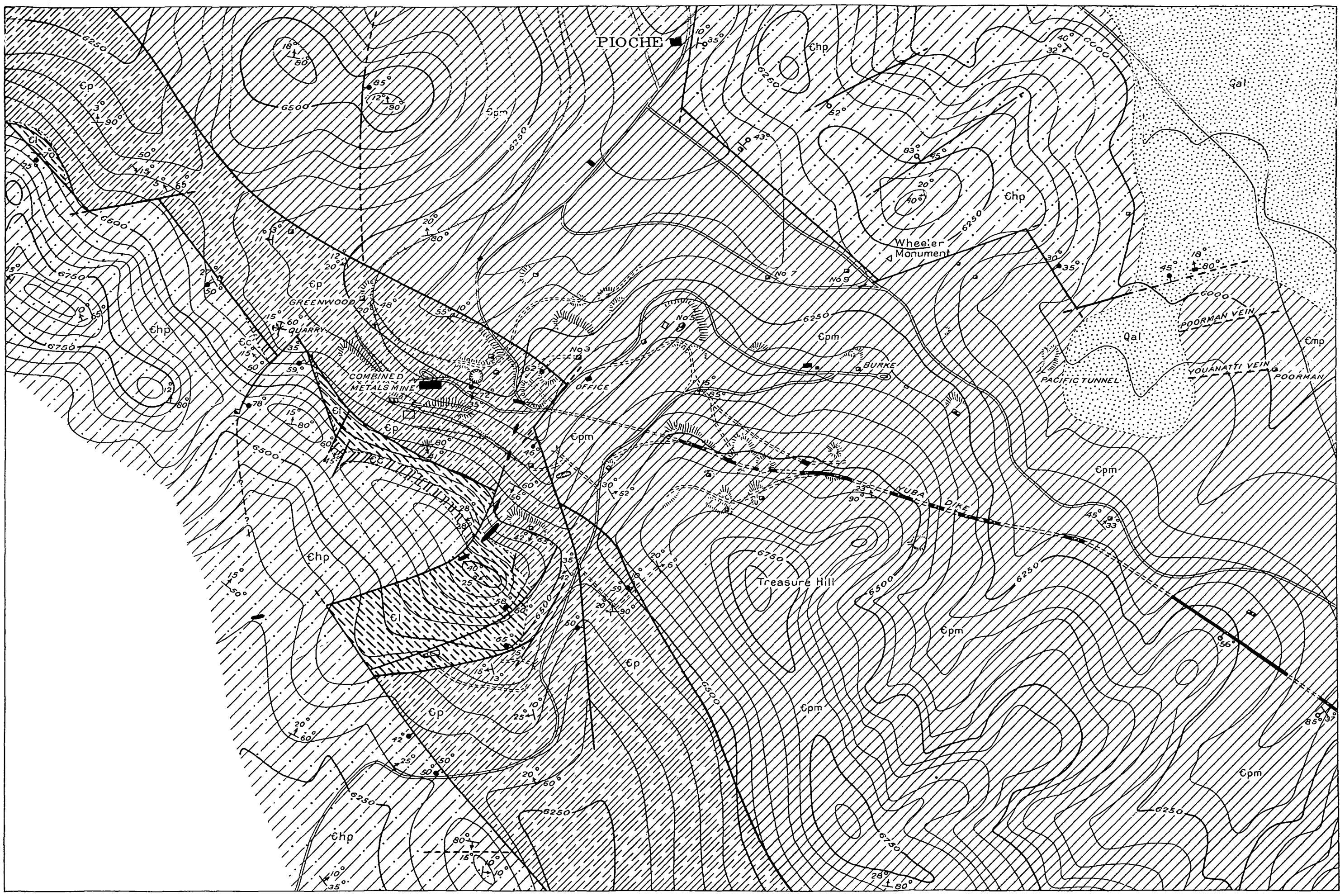

$$
\begin{aligned}
& \text { QUATERNARY } \\
& \text { CAMBRIAN } \\
& \text { EXPLANATION }
\end{aligned}
$$

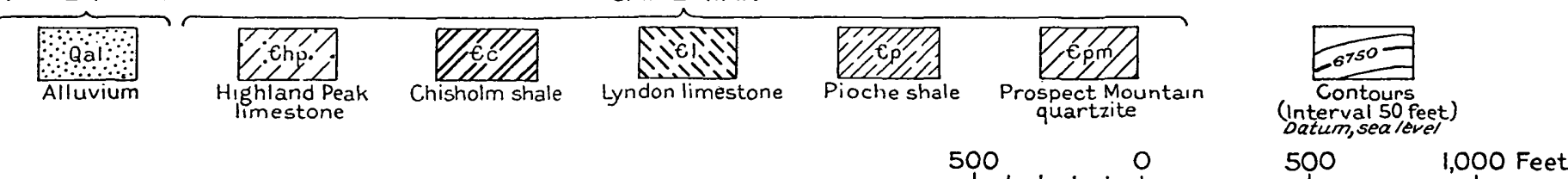


the Ely Range are separated from the adjacent quartzites and limestones by fault boundaries.

Petrography.-The Pioche shale is a yellow or brown, rarely red argillaceous shale. In places it is so fine grained that individual mineral grains do not show. Commonly, however, it is distinctly micaceous, and the small scales of mica are usually sufficient to distinguish the rock, even in small pieces, from the similar Chisholm shale. In the Ely Range the rock is coarser, more micaceous, and more quartzose, in some places approaching a schist in appearance. Where quarried at Pioche it is a finely laminated greenish-gray micaceous rock that turns brown on weathering. The microscope shows quartz, in small angular grains as much as 0.04 millimeter in diameter; chlorite, muscovite, and biotite, named in the order of abundance, in parallel flakes as much as 0.2 millimeter in width; and calcite, with small amounts of pyrite and kaolin and minute undetermined accessories. The shale is banded and foliated as the result of the parallel arrangement of the detrital mica, and it shows considerable change from its original character.

The Pioche shale contains interbedded limestones and sandstones, especially in its middle and upper parts. In the Lyndon Gulch section (fig. 4) there are three sandstone layers aggregating $111 / 2$ feet in thickness (1 per cent of the section) and 13 limestone layers aggregating 76 feet (nearly 7 per cent of the section). The limestone is gray to olive-brown, laminated, and nodular; some of the layers are fossiliferous. These limestones are locally replaced by sulphide ores, as in Lyndon Gulch and at the Combined Metals mine. They are the most productive ore zones in the vicinity of Pioche.

Thickness and sections.-The only place where the formation is unfaulted and where its thickness can be accurately measured is along the west base of the Highland Range. A traverse of the formation 2 miles south of Bennett Pass gave a thickness of 1,655 feet. A better exposed and probably more accurate section (fig. 4), taken on the ridge north of Lyndon Gulch, gave a thickness of 1,120 feet. As the soft shales are in part covered with débris, especially in the lower part of the section, there is some chance for error, but the dips are nearly uniform, and the error is believed to be not large.

At Pioche, the type locality, the upper 170 feet of the Pioche shale is shown above the old Susan Duster

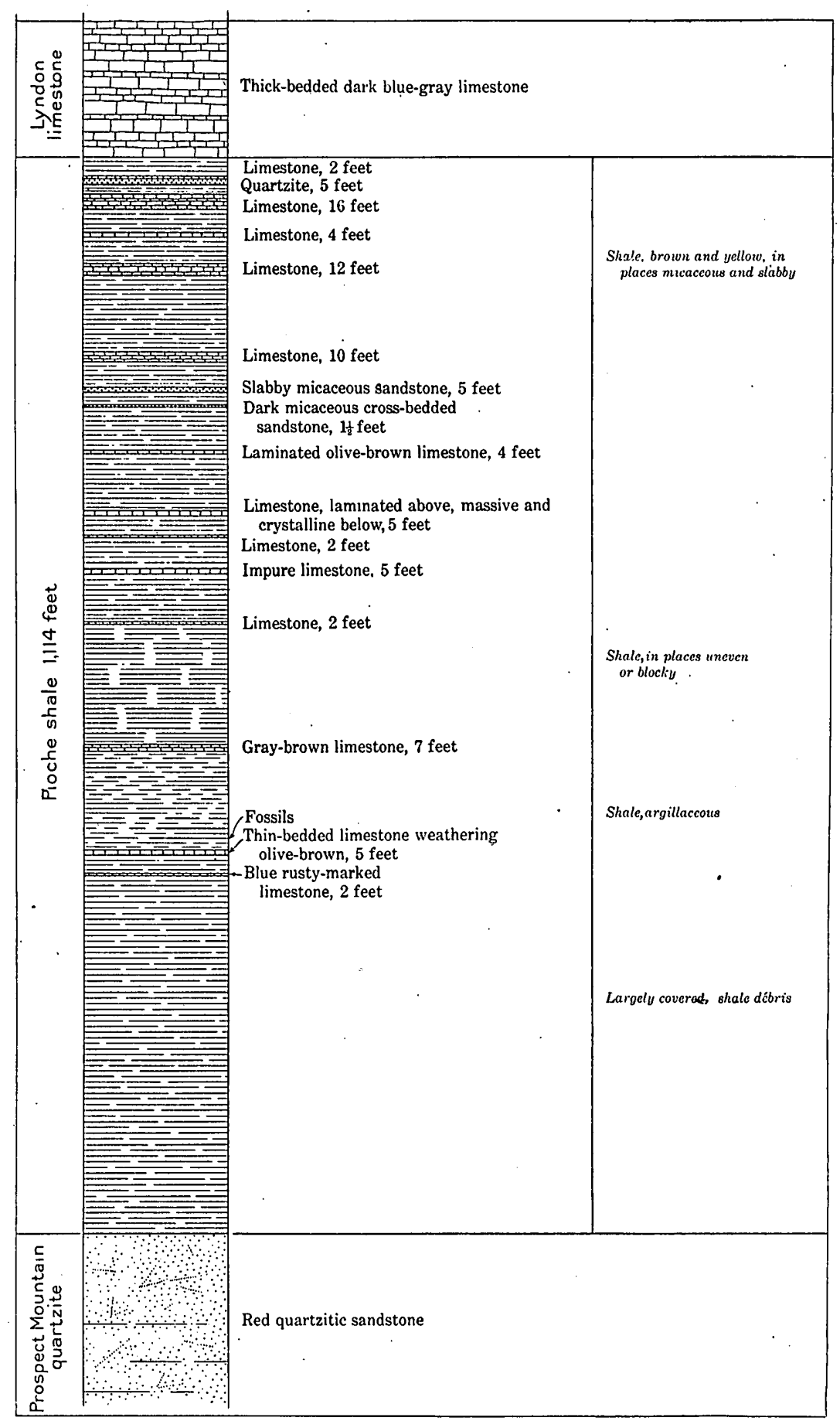

Frgure 4.- Section of Pioche shale in Lyndon Gulch

shaft, and lower beds are found west of the divide, but the rocks are much faulted, and it is impossible to make out a continuous section. Individual limestone beds in the shale can be used for mapping the details of faulting in the vicinity of the Combined Metals mine. 
Age.-Walcott ${ }^{10}$ gives the following list of the fossils found 8 miles north of Bennett Spring, on the west side of the Highland Range:

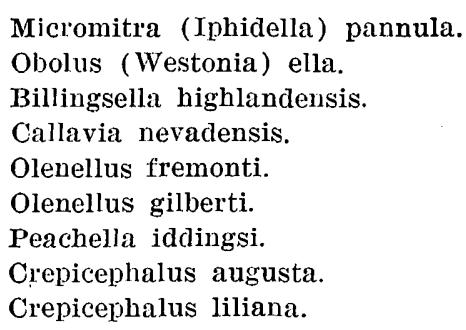

He also gives ${ }^{11}$ the following as found in the "limestone and interbedded siliceous shales of the Pioche formation just above the quartzite on the east side of the anticline, near Pioche." This is the locality on the old Pioche-Panaca road already noted (p. 8) as the type locality of the Pioche formation.

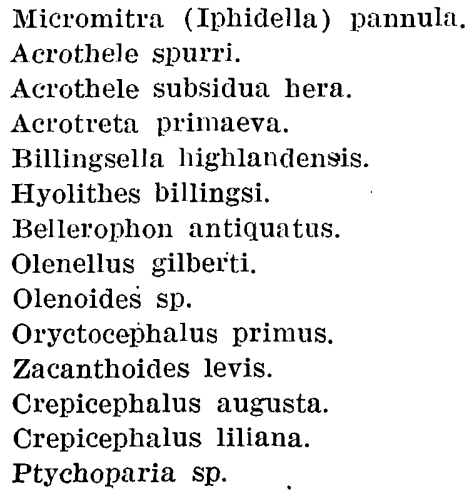

This fauna Walcott assigns to the Lower Cambrian.

\section{MIDDLE CAMBRIAN SERIES}

LYNDON LIMESTONE

Name and distribution.-The Lyndon limestone, typically exposed in Lyndon Gulch, is present in the Highland and Ely Ranges and lies between the Pioche and Chisholm shales. It is best shown along the western slope of the Highland Range, where it parallels the Pioche shale for 8 miles and makes, by reason of its greater hardness in contrast with the shales above and below it, a conspicuous line of cliffs. It is seen, in normal position, on the west side of the range south of Bennett Pass and on the west side of The Bluffs.

Petrography and sections.-The Lyndon limestone varies in character at different levels and almost in successive beds. The lower half is a fine-grained dark-gray thick-bedded limestone, much of which on weathering breaks into thin layers and small chunky débris. The upper half is a lighter-gray and more coarsely crystalline rock, usually thick bedded but showing distinct partings. Toward the north end of

${ }^{10}$ Walcott, C. D., Cambrian Brachiopoda : U. S. Geol. Survey Mon. 51, p. $189,1912$.

11 Idem, p. 192. the Highland Range this upper part of the Lyndon shows as a white band along the west side of the range.

The rock types included in the Lyndon limestone are so much like those in the Highland Peak limestone that it was not found possible in the field to separate them on lithologic grounds alone. Fossils are practically absent from both. The Chisholm shale lies between them in the normal succession. Where that is present the Highland Peak and Lyndon limestones can be mapped separately, but the Chisholm does not occur in the Highland Range north of Stampede Gap. It is likely that north of Stampede Gap and at places in the Ely Range faulting has brought the Lyndon limestone against the Highland Peak limestone. If so, the presence of the Lyndon has not been recognized and all the limestone has been mapped as Highland Peak. In all places where the Lyndon is shown on the geologic map it has been recognized by its structural relations to one or the other of the two shales.

The following section was taken on the ridge south of Peaseley Canyon, on the west side of the Highland Range:

Section of Lyndon limestone on ridge south of Peaseley Canyon

Thick-bedded gray limestone, finely crystalline, weather-

ing light gray

Light-gray to white limestone, finely to somewhat coarsely crsytalline, in part a marble. Usually massive, but showing distinct, locally widely spaced partings.

Blue limestone, thick bedded, with closely spaced

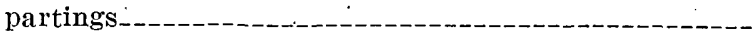

Blue-black limestone, massive but with closely spaced partings and weathering into small débris_-_-_-_----- 120

Blue-black thick-bedded limestone, banded; a cliff mạker

Feet

Age.-Fossils were not found in the Lyndon limestone, but the formation is here assigned somewhat arbitrarily to the Middle Cambrian, along with the conformably overlying Chisholm shale, which contains abundant Middle Cambrian fossils.

\section{CHISHOLM SHALE}

Name and distribution.-The Chisholm shale, named from its occurrence at the old Chisholm mine, on the west side of the Ely Range 2 miles west of Pioche, is a yellow or red-brown argillaceous shale, lying between the Lyndon and Highland Peak limestones. It occurs in regular sequence with the associated formations along the west base of the Highland Range. It is not found north of Stampede Gap, but whether this is due to actual failure of the shale to 
continue north or to disappearance through faulting is uncertain; probably the latter explanation is the true one. In the Ely Range the distribution is very irregular, owing to the faulting. The shale can be traced interruptedly from a point south of the water tank above Pioche nearly to the north end of the range. It occurs, again with interruptions, along the west side of the limestone hills that are east of the PiochePanaca road southeast of Pioche. The Chisholm shale is easily recognized by its physical character and so makes an excellent guide in working out the structure of the region.

Petrography.-The rock is a fine-grained yellowbrown or red-brown laminated argillaceous shale, which weather's to small flat débris. It appears minutely micaceous under the lens, though not to the unaided eye, and by this finer grain it can usually be told from the Pioche shale. In the Chisholm shale, as in the older Pioche shale, layers of limestone are interbedded.

Thickness.-The Chisholm shale seems to vary considerably in thickness. A measured section near the south edge of the Highland quadrangle (given in detail below) showed 180 feet. Along the west side of the Highland Range it is 100 to 150 feet thick. In the Ely Range it appears to be thinner.

Sections.-One of the best sections seen was just north of Klondike Gap, near the south edge of the Highland quadrangle. This section is as follows:

Section of Chisholm shale norih of Klondike Gap

Highland Peak limestone.

Chisholm shale:

Shale

Olive-gray limestone

Shale_.

Olive-gray limestone

Shate-

Dark-blue, red-stained even-bedded limestone

Shale, largely covered.

Lyndon limestone.

Age.-The Chisholn shale is the most abundantly fossiliferous of the Cambrian formations. The following species are listed by Walcott, ${ }^{12}$ as found at the Chisholm mine:

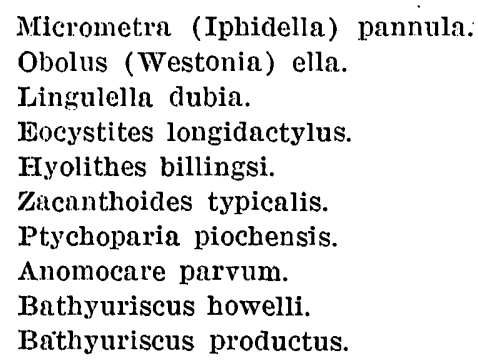

This fauna Walcott assigns to the Middle Cambrian. As the Chisholm shale is only 400 feet above the

wa Walcott, C. D., Cambrian Brachiopoda : U. S. Geol. Survey Mon. 51, p. 192,1012 .
Lower Cambrian Pioche shale it evidently belongs near the base of the Middle Cambrian.

HIGHLAND PEAK LIMESTONE

Name and distribution.-The Highland Peak limestone, named from Highland Peak, in the Highland Range, in whose western slope the rocks are best shown, is one of the thickest formations of the district and occupies a larger area than any other formation.

It makes the main Bristol-Highland Range from the south edge of the Highland quadrangle north to a point about $2 \frac{1}{2}$ miles south of Bristol Pass, where the Cambrian formations are faulted out by the northeast transverse Ida May fault. The chief exception to the foregoing statement is the down-faulted belt of Mendha limestone that lies east of the crest of the range from a point north of Arizona Peak to a point south of Dead Deer Canyon and reaches a maximum width of $2 \frac{1}{2}$ miles. The Highland Peak limestone also makes parts of the lower ranges southwest of the Highland Range. In the Ely Range it makes most of the limestone area west and north of Pioche and of the low limestone hills east of the new Panaca road to the southeast, extending nearly to the PanacaModena road.

Petrography and sections.-The rock is commonly a light-gray to dark-gray or black rock on fresh fracture and weathers gray or dark gray. It ranges from a fine-grained rock that does not show individual grains to a medium-coarse recrystallized rock. Many of the beds on cross fracture are variously mottled in shades of gray, owing to differences in coarseness of grain or in degree of dolomitization. Most of the beds, including all the black fine-grained beds, are limestone and effervesce freely with acid; but some of the more crystalline beds are dolomitic. Flint or chert is found in a very few places. The beds reach 4 to 5 feet in thickness, although parts are thin bedded. Even these thin-bedded parts in places make ledges of considerable height, which weather to slabby débris. The whole formation is a repetition of these variants, so that it is difficult or impossible to determine vertical position in the formation by the character of its most common rock types.

The formation includes three exceptional rock types which have at least a general significance as horizon markers.

1. Light-gray siliceous laminated and thin-bedded dolomites and dolomitic limestones, which weather light gray or white, occur as interbedded members from 2 or 3 feet to more than 60 feet in thickness. In many of the beds the laminae are broken, making a sort of flat-pebble conglomerate, though the fragments are angular and not rounded. These beds are found in the middle and upper part of the Highland Peak 
limestone and are not found in any other Paleozoic formation.

2. Thick ledges of well-bedded and thick-bedded limestone, much of it white, with parting beds of laminated limestone as much as a foot in thickness, occur near the top of the formation. These beds are too high in the formation to show in the Ely Range but are conspicuous features along the crest of the Bristol Range as viewed from the flat to the east.

3. A striking succession of beds was seen in the Pioche Hills east of Panaca. From above down they are as follows:

Section of Highland Peak limestone east of Panaca

Thin-bedded black limestone passing up into thickerbedded, finely mottled, rough-weathering beds; the normal Highland Peak limestone.

Gray thin-bedded laminated limestones with large masses of black chert and some white chert in the lowest layers

Gray siliceous dolomite, weathering rusty brown; thinbedded above, giving thin platy débris; thicker below, weathering to chunky pieces

Dark to black thin-bedded and laminated limestone.-.-Gray limestone specked with calcite in beds as much as 6 feet thick, weathering light gray. Some layers at the top are laminated. These beds are.in places dark. and may have been so generally at the first............

The combination of the four lower members of this section makes a zone that can be recognized with certainty. Four miles southeast of Pioche it lies 1,200 feet above the Chisholm shale, but at this locality, owing to faulting, exact measurement is probably impossible. The zone can be traced north from Panaca for several miles and is again found in the hills west of Pioche, north of the Prince mine, where it can be used to work out the faulting. It was not seen in any of the traverses of the west side of the Bristol-Highland Range and probably does not occur there, though it was found at one point at the east base of the range near the Jackrabbit mine.

The following section of the lower and middle parts of the Highland Peak limestone was taken on the divide south of Peaseley Canyon, in the Highland Range:

Section of part of Highland Peak limestone south of Peaseley Canyon

Dark-gray to black well-bedded limestones, making the steep cliffs of the west face of Highland Peak

Black limestones, well bedded and thinly parted, usually breaking to flat slabs.

Gray limestones, alternatingly lighter and darker, varying from fine grained to coarser grained and distinctly crystalline, medium to thick bedded.

Massive dark-blue limestone, thinly parted; a cliff maker.

Chisholm shale.
The following section taken along the crest of the Bristol Range due east from the Bristol mine shows the character of the highest beds of the formation:

Section east of Bristol mine

Feet

Mendha limestone: Fossiliferous crystalline thin-bedded limestone

Highland Peak limestone:

Massive gray-white, indistinctly banded limestone. Partings more or less laminated.

Gray crystalline limestone with thinly laminated layer's at several levels, especially toward the top. Dark-gray, more or less laminated limestone........ Cliff of massive, finely crystalline white or lightgray limestone. Partings of laminated limestone as much as 10 inches thick, giving prominent bedding

Light-gray, somewhat mottled limestone-.-...-.----Dark-gray to black mottled limestone

Dark-gray to black mottled limestone with interbedded light laminated limestone

Rather coarsely crystalline light-gray, faintly mottled limestone; dark at top

Gray-black limestone.

Gray massive mottled limes

Black limestone_..- 40

White, gray, and black limestones, in part mottled.- $\quad 180$

White limestone

Blue-black, yellow-mottled limestone-_-_-_-_._-_.-- 40

Thickness.-Even the approximate thickness of the Highland Peak limestone is unknown. Its lower limit is the top of the Chisholm shale, and its upper limit is a series of thin-bedded crystalline, in places oolitic limestones with abundant trilobite débris which makes the base of the overlying Mendha.

The west face of the Highland Range seems the most promising place to measure the section. There the base of the formation shows, and 2,500 to 3,000 feet or more of beds are exposed, but known faulting of indeterminable amount makes any accurate measurement of the total thickness impossible. Southeast of Panaca the Ely Range consists wholly of Highland Peak limestone, the overlying Mendha not showing. If the thickness of the formation is calculated from the angle of dip and width of outcrop, it is considerably in excess of 3,000 feet; but here again faulting may affect the apparent thickness. Not only does faulting make the measurement of any continuous section impossible, but the absence of good guide horizons within the Highland Peak precludes piecing up the total thickness from partial sections. In the columnar section (fig. 3) a rather arbitrary thickness of 3,000 feet is given.

Age.-The Highland Peak limestone is practically without recognizable fossils. The Chisholm shale just beneath has been placed in the Middle Cambrian. The overlying Mendha limestone, however, has been 
identified as Upper Cambrian, and its lowest beds are considered basal Upper Cambrian. (See p. 14.) As the underlying Chisholm shale (p. 11) evidently represents only the lower part of the Middle Cambrian, the Highland Peak limestone must represent the bulk of the Middle Cambrian.

\section{UPPER CAMBRIAN SERIES}

\section{MENDHA LIMESTOND}

Name and distribution.-The Mendha limestone, named from the Mendha mine, on the west side of Arizona Peak, which is entirely composed of these rocks, includes nearly 2,000 feet of limestones and dolomites which lie with apparent conformity above the Highland Peak limestone. The formation is not seen in normal position under the Ordovician; as the contact with the Ordovician is everywhere a fault contact.

The Mendha is not found in the Ely Range. It is present in the Bristol Range quadrangle just north of the Ida May fault west of the Jackrabbit mine and in small infaulted masses along the crest of the range to the south. The larger areas are all in the Highland quadrangle, where they make three down-faulted north-south belts. The eastern belt includes a small area at the south end of the Bristol Range, Arizona Peak, and a large mass in the eastern slope of the main Highland Range. This whole belt is structurally a graben, separated by normal faults from the Highland Peak limestone on the east and west. A second interrupted north-south belt lies along the west side of the Highland Range and includes several areas between the Ely Springs Range and the main range near Manhattan Gap and, farther south, a large area in the Black Canyon Range. The part of this belt north of the Comet mine is a thrust-fault block. The third belt comprises two areas, one on the west side of the Ely Springs Range, the other about Monument Canyon. The best sections of Mendha rocks are found on Arizona Peak and in Dead Deer and Black Canyons.

Petrographic character and sections.-The basal beds of the Mendha formation are thin-bedded gray limestones, in places stained yellow or rusty-red on weathering, which in the hand specimen are rather coarsely crystalline, locally oolitic and rusty-specked. They contain abundant fossil débris, almost wholly fragments of trilobites, most of which are specifically unidentifiable. By reason of their contrast with the underlying Highland Peak limestone these beds mark an easily recognizable horizon, which has helped greatly in working out the structure of the main Bristol-Highland Range.
Above the basal beds just described lies the main mass of the Mendha, which consists of thick and thin bedded limestones and dolomites. The rocks are so much faulted that it has not been possible to get a continuous and complete section. Fossils are abundant at many levels but chiefly as unrecognizable débris. Beds that resemble the basal beds and carry little but trilobite fragments are thought to be low in the series. Beds in the middle and upper part of the formation carry besides trilobite débris small chitinous brachiopods, Hyolithes, and small gastropods. In many places these beds are conglomeratic. Chert is common in the middle and upper parts of the formation but is absent in the lower part.

The following sections show the physical character of the Mendha. The first, taken south of Dead Deer Canyon on the southwest side of the 7,318-foot hill, is typical of the lower part of the formation.

Section of lower part of Mendha formation south of Dead Deer camyon

White massive dolomite in beds as much as 8 feet thick. The beds show close-spaced parting planes but break into large blocks

Gray limestone, thinly parted, making the lower part of the cliff at the top of the hill. Layers throughout more or less oolitic and mottled. White chert in sheetlike lenses is found from the base up.

Thin sandstones and layers of alternating sandstone and limestone, weathering to flat rusty débris______- 10

Gray thick-bedded crystalline limestone__....._._._. 230

Gray limestone, some beds 5 feet thick, much of it crystalline, oolitic and mottled.

Gray, rather thick-bedded limestone, 60 feet thick, passing up into well-bedded limestone in beds 1 or 2 feet thick. Layers commonly oolitic, rarely conglomeratic and yellow streaked. Breaks down easily into slaty débris_-Top of Highland Peak limestone. Feet 85

The next section, taken on the east side of the ridge northeast of Monument Canyon, is also measured up from the top of the Highland Peak limestone:

Section of Mendha limestone 1 mile northeast of Monument canyon

Dark thinteded limestone sparingly fossiliferous

Thicker-bedded black, somewhat cherty dolomite, weathering to pitted surface_____ 150

Gray crystalline dolomite._. 150

In part covered; soft crystalline fossiliferous limestone, weathering olive-brown. Mainly thin bedded but with numerous thicker beds._. 925 Highland Peak limestone. $\quad \overline{1,625}$

The next section (p. 14) does not reach to the base of the formation; 
Section of part of Mendha formation on north side of Black Cangon

Gray limestone, in thin to medium beds, single beds reaching a maximum of 3 feet. Some layers aphanitic, some crystalline and containing trilobitic material, and some conglomeratic and rusty specked._......Black dolomite in distinct beds 3 to 5 feet thick. Some beds contain chert in lenses and layers. Weathers black. Many beds are irregularly streaked with white dolonite, which may form 50 per cent of the bel

Massive light-gray crystalline dolomite in beds 3 to 4 feet thick. Weathers light gray and pitted.

(1)

The following section, made on the south face of the steep cliff at the head of Dead Deer Canyon, 3,000 feet east-southeast of Highland Peak, likewise does not reach the bottom of the formation:

Section of part of Mendha formation at the head of Dead Deer Canyon

Soft crystalline limestone, some layers conglomeratic, weathering rusty yellow. Not cherty or with very little chert.

Dark massive cherty dolomite, some beds crystalline and indistinctly fossiliferous. At base some coarsely oolitic beds

White massive, thick-bedded dolomites

Blue-gray medium-bedded, well-parted rusty mottled limestone, some layers conglomeratic. Some lenses and bands of chert at top

Sandy laminated limestone-

Massive soft, thinly parted limestone, in part oolitic and yellow stained

Age.--Many beds of the Mendha limestone contain abundant fossil débris, but it is difficult to collect good identifiable material. C. E. Resser ${ }^{13}$ states that the oolitic and crystalline thin-bedded rusty-weathering limestones that mark the base of the Mendha commonly contain Crepicephatus and are to be referred to the base of the Upper Cambrian. Collections obtained higher in the formation indicate Upper Cambrian age. Material collected on the east slope of Arizona Peak, well up in the formation, shows what appears to correspond to the Seçret Canyon fauna of the Eureka district, and a lot collected on the crest of the Black Canyon Range immediately north of the canyon contains Eurekia, which marks a still higher horizon.

\section{ORDOVICIAN SYSTEM}

Ordovician rocks are found in three areas-one just south of Bristol Pass, another 11/2 miles northwest of Monument Canyon, in the southwest corner of the Highland quadrangle, and a third, the largest, making

\footnotetext{
1.3 Personal communication.
}

a north-south belt that extends the length of the Ely Springs Range. The largest area has by far the best exposures, which have served as a basis for the following description of the Ordovician rocks.

\section{YELLOW HIL LIMESTONE}

The lowest beds of the Ordovician are here named Yellow Hill limestone, from exposures in Yellow Hill, near the center of the Ely Springs Range. The beds dip northwest, so that the lowest beds are on the east slope of the hill. They consist of medium-bedded gray limestones, weathering light gray and in part conglomeratic. Fossils are uncommon. These beds pass up into fine-grained gray limestones in beds from 2 or 3 inches to a foot in thickness, which cap the hill and are well exposed in its west face. Conglomerate layers are common, and the formation weathers to gray or yellowish slabs and débris. Thin-bedded layers alternate with thicker beds and give a fluted cliff face on weathering. Fossils are common at a few horizons. The total thickness of the Yellow Hill as calculated from the dip of the rocks and the slope of the hill is 670 feet.

Faults bound the Yellow Hill limestone so that neither the base nor the summit of the formation is shown; it is therefore impossible to tell whether the Ordovician lies conformably on the Upper Cambrian or not.

A fairly large fauna was collected in the saddle southeast of Yellow Hill and at a somewhat higher horizon about $1 \frac{1}{2}$ miles farther north. As essentially the same fauna is represented in the two collections, they have been combined in the following list. This fauna is representative of the uppermost beds of the Yellow Hill limestone. The fossils were identified by Edwin Kirk.

Calathium sp.

Syntrophia calcifera.

Taffia sp.

Orthis sp.

Tetranota sp.

This fauna, according to Kirk, is of late Beekmantown age and is correlative with the upper part of the lower or Beekmantown portion of the Pogonip limestone of the Eureka district.

TANK HILL LIMESTONE

The Tank Hill limestone, here named from its exposures on the west face of Tank Hill, in the Ely Springs Range, makes a north-south belt the entire length of the range. The lower part consists of gray fine-grained thin-bedded limestones containing some conglomeratic beds; the upper part is thicker bedded and makes a line of high cliffs a little below the Eureka quartzite. The upper 50 feet of the formation 
consists of shaly limestone and sandy shale. Fossils are abundant, and some layers contain many Leperditia and Orthis.

An especially favorable place for the collection of fossils from the Tank Hill limestone is near the north end of the Ely Springs Range on the west side. Here the lower portion of the formation as exposed is characterized by an abundance of Receptaculites ellipticus, R. mammillaris, and Endoceras sp. Above this horizon an abundant fauna is present, as shown in the following list prepared by Edwin Kirk:

Rauftella.? s!!

Tetmdium sp.

Batostoma. sp.

Orthis sp.

Pleurotomaria lonensis.

Maclurites sp.

Lophospira sp.

Tetranota sp.
Modiolopsis sp.
Endoceras sp.
Leperditia bivia.
Illaenus sp.
Amphion near A. salteri.

In the uppermost portion of the formation, just under the Eureka quartzite, certain layers carry large numbers of Leperditia bivia, and others are crowded with an Orthis very like $O$. tricenaria.

The fauna of the Tank Hill limestone is stated by Kirk to be of Chazy age and is essentially the same as that of the upper part of the Pogonip limestone of the Eureka district.

EURETKA QUARTZITE

Above the Tank Hill limestone comes a very pure quartzite which is here correlated with the Eureka quartzite of Eureka, Nev. ${ }^{14}$ It is a white and palered vitreous quartzite, in places a quartzitic sandstone, showing sand grains under the hand lens. Where unbrecciated, it occurs in distinct beds from 6 inches to 6 feet thick. Measurements of the thickness of the formation vary between 150 and 250 feet; 200 feet may be taken as an average.

The quartzile, repeatedly faulted, can be traced from north to south through the Ely Springs Range, its broad outcrop at the south end of the range being a dip slope. It caps the low hill northwest of Monument Canyon. It is not found elsewhere in the region unless it is represented by some of the quartzitic sandstones in the faulted area immediately south of Bristol Pass.

The formation is unfossiliferous, but its relation to the rocks above and below fix its Ordovician age. Fossiliferous Ordovician rocks of the same type are found below it throughout the Ely Springs Range, indicating conformity. It is tentatively classified as Middle (?) Ordovician.

\section{BLY SPRINGS DOLOMITE}

Name and distribution.-The Ely Springs dolomite is here named from its exposures in the Ely Springs

16 Hague, Arnold, Geology of the Eureka district, Nev.: U. S. Geol. Survey Mon. 20, p. 54, 1892.
Range. It lies apparently conformably above the Eureka quartzite, makes a belt half a mile wide along the crest of the range as far south as Ely Springs, and occurs in smaller areas still farther south.

Petrography and sections.-Lithologically the formation is a dolomite or dolomitic limestone. Usually it is a dark-gray dolomite, weathering smoky brown, in beds of variable thickness to a maximum of 5 feet. Some beds are laminated. It is cherty at a number: of levels, at some abundantly so. In the upper part are some thick beds of gray dolomite.

The following section was measured at the north end of the range, from the quartzite up through the Ely Springs dolomite and into the overlying Silurian, which is a very similar dolomitic limestone:

$$
\text { Section at north end of Ely Springs Range }
$$

Silurian :

Gray dolomite in thick beds (at the top of the hill)

Massive dark-brown dolomite, cherty in its upper part

Feet 25 75

Ordovician:

Ely Springs dolomite-

Even-bedded light-gray dolomite, much of it laminated. Some included layers of dark dolomite

Dark-gray dolomite, medium to thick bedded, cherty in its middle and lower parts_-_-_--Blue-black finely crystalline dolomite, weathering smoky brown; beds average 2 feet thick; somewhat thicker bedded above; sparingly cherty, fossiliferous.

Eureka quartzite (white to pink quartzite in beds as much as 5 feet in thickness).

'The following section was taken up the east side of the range half a mile south of its north end:

Section on east side of Ely Springs Range

Silurian: Gray to brown thick-bedded dolomite, cherty in the lower part. Fossil pentameroid Silurian brachiopods (Virgiana sp.) 150 feet below the top. Ordovician :

Ely Springs dolomite- $\quad$ Feet

Thick ledges of gray dolomite_- 40

Cherty thick-bedded dolomite_________ 290

Gray and brown dolomites____._-_._- 240

Brown massive, more or less cherty dolomite; poorly preserved brachiopods and corals in the upper part_-_-_- 200

The section starts from some undetermined level above the quartzite and is probably complicated by faulting, but it shows the general character of the formation. The rocks in this section are unlike the Ordovician limestones beneath the Eureka quartzite and resemble in bedding, color, and general dolomitic character the lower part of the Silverhorn dolomite of the Devonian as shown in the Bristol Range quad- 
rangle. They differ from the Devonian chiefly in the abundance of chert. The "spaghetti" dolomites that are characteristic of the Devonian are absent, except in a few layers at the top of the section. Neither the summit of the Silurian nor the bottom of the Devonian is seen in the Pioche area.

A similar relation exists between the rocks of the two periods in the Eureka district, where the Lone Mountain limestone (Silurian and Upper Ordovician) underlies the Nevada limestone (Devonian)..$^{15}$

Age and fossils.-At the north end of the Ely Springs Range the following fauna was collected, as determined by Edwin Kirk:

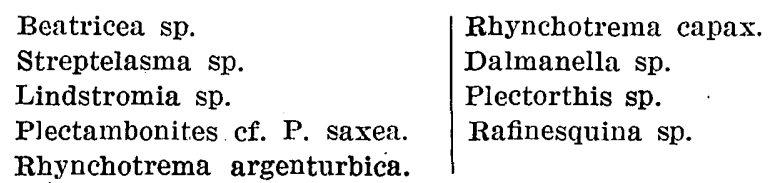

According to Kirk this fauna is widely spread throughout the Rocky Mountain and Great Basin regions. It is correlative with the Montoya limestone of Texas, with part of the Fremont limestone of Colorado, with part of the Bighorn dolomite of Wyoming, and with an unnamed formation between the Eureka quartzite and the Silurian of the Eureka district, Nevada. It is of Upper Ordovician (Cincinnatian) age. In the past it has been correlated with the Richmond and is probably approximately of that age.

\section{SILURIAN SYSTEM}

The Ely Springs dolomite, as shown in the section given on page 7 , is followed by similar brown and gray dolomites that carry Silurian (Niagaran) fossils. These beds are found in a narrow strip along the crest of the north end of the Ely Springs Range but have not been recognized in any other part of the district. They are indicated approximately on the geologic map, but no formation name has been given to them.

Poorly preserved pentameroid brachiopods, identified by Edwin Kirk as Virgiana sp., were the only fossils collected in the Silurian dolomites. They were found $\mathbf{1 5 0}$ feet below the top of the section described on page 15. Mr. Kirk comments on these fossils as follows :

This pentameroid is found in the Fusselman limestone of the El Paso region, ${ }^{18}$ with which the present formation correlates. It has also been collected in Nevada from scattered localities, no sections having been made and no formation names having been given.

The formation is correlative with the upper or Niagaran part of the Lone Mountain limestone of the

\footnotetext{
${ }^{15}$ Hague, Arnold, Geology of the Eureka district, Nev.: U. S. Geol. Survey Mon. 20, p. 63, 1892.

${ }^{16}$ Richardson, G. B., U. S. Geol. Survey Geol. Atlas, El Paso folio (No, 166), p. 4, 1909 .
}

Eureka district and with the Fusselman limestone of Texas and New Mexico.

\section{DEVONIAN SYSTEM}

Two. Devonian formations are distinguished in the district-the Silverhorn dolomite, of Middle Devonian age, and the West Range limestone, of Upper Devonian age. These two formations are so closely associated that they are described under one heading.

SILVERHORN DOLOMITE AND WEST RANGE LIMESTONE

Character.-The Silverhorn dolomite was named ${ }^{12}$ from its exposures south of the old Silverhorn mining camp, 4 miles northwest of Bristol Pass. It is a succession of varied dolomites with some beds of limestone and in the upper part beds of quartzitic sandstone and a capping quartzite 20 to 100 feet thick, the whole reaching a thickness of not less than 3,000 feet.

The West Range limestone was named from exposures in the West Range, in the southwestern part of the Bristol Range quadrangle, where it is well shown in the south slope of a high conical hill $11 / 2$ miles south of the north base of the range. The formation here lies between the basal Mississippian capping the hill and the quartzite forming the top member of the Silverhorn dolomite. Another good section. is found 6 miles to the north, on the west side of Scotty Wash at Silverhorn, where 400 feet of limestone succeeds the quartzite member of the Silverhorn.

The rocks of the West Range formation are bluegray fine-grained limestones, in some places nodular, commonly weathering to a characteristic yellow color. Certain layers are abundantly fossiliferous.

The following are the main rock types of the Silverhorn dolomite:

1. Dark-gray or brown crystalline dolomite of medium grain, weathering to a brownish gray that gives the outcrop a sooty look. It is usually rather thick bedded, making many conspicuous ledges. This rock, like the rest of the series, has been in places broken and then healed by seams of white dolomite. On the edges of some of the beds such dolomite seams lie parallel to the bedding and produce a peculiar banded rock. The microscope shows an aggregate of grains of dolomite, many of them showing crystalline boundaries, averaging 0.10 millimeter in diameter, also a few small grains of quartz that average 0.02 millimeter but reach a maximum of 0.05 millimeter.

2. White-spotted or "spaghetti" dolomite, a striking variety of the brown dolomite which originally contained small branching corals (Cladopora?). These have been replaced by white crystalline dolo-

${ }_{17}$ Westgate, L. G., and Knopf, Adolph, Geology of Pioche, Nevada, and vicinity: Am. Inst. Min. and Meț. Eng. Trans. [preprint] No, 1647 , pp. 3-8, 1927. 
mite, so that the rock is crowded with small curving stems, 2 to 3 centimeters long by 1 to 3 millimeters in cross section. This distinctive texture seems to be confined to the Devonian.

3. A finely crystalline dark-gray, well-bedded, in places laminated dolomite, weathering gray. The beds reach a maximum thickness of 5 to 6 feet.

4. Dark-gray fine-grained noncrystalline limestone in beds as much as 4 feet in thickness.

5. Sandy dolomite, light gray both on freshly broken and on weathered surfaces. It contains abundant quartz sand in well-rounded grains 0.5 millimeter or less in diameter, which show well on the weathered surface. The rock is commonly laminated, the laminae differing in the amount of sand, and in places it is cross-bedded. In the middle part of the formation these beds, with increase of sand, may locally pass into calcareous sandstones 2 to 3 feet thick.

6. Quartzitic sandstone occurs in the upper part of the formation. Its purest variety is a white or palered rock, which shows sand grains under the lens. The rock lacks the deep-red color characteristic of the Cambrian and Mississippian quartzites of the region. In some places it is open textured, and at one point it ranges within 40 feet along the strike from a porous open-textured sandstone to a vitreous quartzite. It occurs in beds from a few inches to several feet thick and in places makes massive ledges.

Distribution.-The two Devonian formations are found only in the Bristol Range quadrangle. They occur in the Bristol Range from the vicinity of the Bristol mine to Bristol Pass and in several areas in the hills northwest of Bristol Pass as far as Fox Spring and Silverhorn. The entire West Range, excopt for small areas of lava, is Devonian, as well as its continuation in the low hills north of the Cherry Creek road.

All the Devonian of the main Bristol Range north to Bristol Pass, of the west third of the area north of the pass and east of Fairview Wash, and of the east half of the West Range is in an overthrust fault block. (See p. 42.) The rocks in this block are brown and gray dolomites, with gray limestones and quartzites in lesser amount. They can be recognized as Devonian on lithologic grounds, but they are so intricately faulted and brecciated that it is impossible to determine structure or measure sections; nor have recognizable fossils been found in them. The Devonian area southeast of Blind Mountain and crossing the edge of the Bristol Range quadrangle is believed to be a downfaulted piece of the overthrust block.

On the west side of the West Range the Devonian rocks, especially the Silverhorn dolomite, are better exposed than anywhere else in the district. The southarn 4 miles of the range, north to the north boundary of T. 2 N., shows the same thick brown dolomite and "spaghetti" dolomite, gray dolomite, in places sandy, and limestone like that found below the quartzite member in the section at Silverhorn. At the south end of the range the westward-dipping beds have a thickness of 2,250 feet, unless there is repetition due to obscure faulting. Farther north the beds dip to the north and appear to be repeated by a succession of east-west faults. North of $\mathrm{T}$. $2 \mathrm{~N}$. the top quartzite member forms northward-sloping ${ }^{\circ}$ cappings of the hills south of the Cherry Creek road. No good section of the quartzite shows, but its thickness here is estimated at 100 feet. Faults bring the quartzite, with associated limestone, again to the surface in the hills just north of the road.

Sections.-The most complete Devonian section is that in the hills south of Silverhorn. The traverse was made from the south edge of the Devonian area due north to hill 6440, thence west for 2,000 feet along the crest of the hill, and thence northwest across the valley 2,000 feet to hill 6247 . The section is as follows :

Section of Devonian rocks south of Silverhorn

West Range limestone (Upper Devonian): Mediumbedded limestone; many beds subdivided by wavy parting planes into thin slabs and forming yellowish débris and soil. Fossil lots 1080 and 1535 collected near bottom. These beds pass up into gray thick-bedded limestones which belong at the base of the Mississippian.

Silverhorn dolomite (Middle Devonian) :

Red thick-bedded quartzitic sandstone

Gray, smoky dolomite, with some interbedded white dolomite

Two well-bedded quartzitic sandstones, the upper 15 feet, the lower 10 feet thick, separated by 8 feet of gray limestone.

Massive smoky-brown dolomite, with many "spaghetti " beds and minor amounts of gray dolomite_ Thin-bedded, slabby limestone; fossil lot 1534_-.--_Brown dolomitic limestone

Mainly dark dolomite, weathering dark brown. Abundant "spaghetti" beds in the upper part. Some interbedded gray laminated limestone. Some of the thicker beds make ledges 15 to 20 feet high along the hill. Capped by 5-foot sandstone at summit 6440. Fossil lots 1550 and 1551 collected 500 feet below the top_._-_._._. 390

Thin-bedded limestone

Massive and thick-bedded gray and smoky-brown dolomite and limestone-

As the base of the Devonian is not seen in this section, the total thickness given is a minimum.

A good section of the West Range limestone is given in the south face of the high conical hill 0.1 mile north of the north line of T. $2 \mathrm{~N}$. in the West Range. This is the locality from which the formation

\section{(n)}


was named. The quartzite member of the Silverhorn lies near the foot of the south slope. The section is as follows:

\section{Section in West Range}

B1.istol Pass limestone (Mississippian): Well-bedded dark limestone in beds 4 inches to 2 feet thick capping the liill. No brown dolomite

West Range limestone (Upper Devonian): Thin to medium bedded limestones; fossil lots $99,1554,1555$, 1557

Silverhorn dolomite (Middle Devonian) : Quartzite (not measure(1).

'Two good sections were measured outside the area mapped. One, which shows only the Silverhorn dolomite, was taken on the east side of the Pahroc Range, 14 miles west of Highland Peak and 5 miles west of the west edge of the Highland quadrangle. This section is as follows:

Section of Silverhorn dolomite on east side of Pahroo Range

Sandy quartzite, capping the hill

Feet

Thick and well bedded black fine-grained dolomite, weathering chocolate-brown

Thick beds of gray crystalline dolomite, making cliff below the summit.-

Like No. 7, but generally more or less laminated, with some massive bands of Stromatopora-bearing dolomite, 8 to 10 feet thick, making ledges, and some interbedded gray laminated limestone. Fossil lots 148, 149, 150 , and 152 came from base of this division

Thinner-bedded gray laminated dolomite, with some interbedded brown dolomite

Brown dolomitic limestone

Thin-bedded gray laminated dolomite, with some interbedded brown dolomite.

Brown dolomitic limestone.

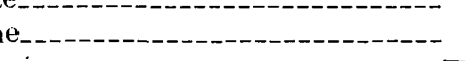

\section{Bis.}

Section on Dutch John Mountain

Feet
260
615

Bristol Pass limestone (Mississippian) :

Gray crystalline limestone, with some black chert; fossiliferous

Gray crystalline limestone in thick indistinct beds; fossiliferous

West Range limestone (Upper Devonian) : Gray medium and well bedded limestone; abundant fossils_--.---.Silverhorn dolomite (Middle Devonian):

Gray-brown "spaghetti" dolomite, with some beds of dark-gray limestone; fossiliferous_._._._._._-

Gray, rather thick bedded dolomite passing up into "spaghetti" beds. Top beds gray, massive wellbedded dolomite. Some beds of laminated dolomite occur.

Light-gray dolomitic limestone in beds as much as $\mathbf{5}$ feet thick

Mainly gray thin-bedded and platy limestone, with a few bands of laminated dolomite, beds of brown dolomite, and beds of "spaghetti".

Blue-black limestone in beds as much as 4 to 5 feet thick and in extreme cases 20 feet, weathering blue-gray; some beds of gray laminated dolomite weathering light gray; and some brown "spaghetti" beds. Few and indistinct fossils.--.--

Gray and blue limestones, weathering brown, with some beds of dolomitic limestone

Massive ledges of thin-parted limestones. Near top some layers are crowded with branching corals. Stromatoporoids occur. Lowest "spaghetti" beds found in the section

Gray limestones, thinly parted but making massive ledges. Bedding in places obscure. Breaks into fine débris. Indistinct fossils

Thinly parted limestone, becoming massive. Makes cliff. Brecciated and seamed with calcite at top_

Fine-grained blue-black limestone in beds as much as 2 feet thick, much of it in thin platy layers_-

Feet 145

305 330

The rocks of the three formations in the section at Dutch John Mountain resemble those of the corresponding formations in the Bristol Range quadrangle

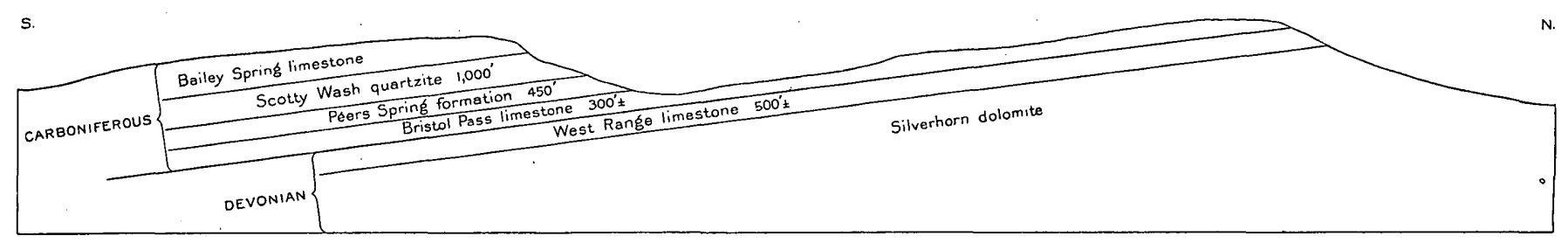

Figure 5.-Section on Dutch John Mountain

The second section was taken on Dutch John Mountain (see fig. 5), just west of the Pioche-Ely Road, 40 miles north of Pioche and 15 miles north of the north edge of the Bristol Range quadrangle. The beds dip gently southwest and are apparently unfaulted. The section is as follows: except for the absence of quartzitic sandstone at the top of the Silverhorn. The absence of the quartzite may be due to failure of sand deposition to extend so far north or to an unconformity between the Silverhorn and West Range formations. No other evidence of unconformity was recognized. 
Fossits and age of Sitverhorn dolomite.-Fossils were found at many points in the Devonian rocks, especially in the Upper Devonian West Range limestone. The locations where collections were made are roted in the sections described on the preceding pages. Those of the Silverhorn dolomite are as follows:

At 1,600 feet above the base of the formation at Silverhorn (lots 1550, 1551), silicified Stromatopora and Cyathophajllum.

At 2,300 feet up in the same section (lot 1534), Atrypar reticularis and Cyrtial? cf. C. norwoodi.

Just below the quartzite at the top of the Silverhorn in the West Range, at the south base of the high hill 4,300 feet northwest of the 6,137-foot summit, the following species (lot 1556) were collected:

Ambocoelia sp.

Atrypa reticularis.

Productella sp.

Several lots of the Pahroc Range section are also considered by Kirk to be Middle Devonian and to belong to the Silverhorn formation. They are as follows: Lats 148 and 149, stromatoporoids; lot 150, Atry'pa retricularis and Spirifer aff. S. argentarius; lot 152, Cladopora? and Striatopora?

The few fossils collected in the Devonian portion of the Dutch John Mountain section were determined by Edwin Kirk in the field. A block of float limestone, apparently derived from beds near the base of the Silverhorn dolomite as exposed, contained a specimen of Stringocephalus. ${ }^{18}$ The "spaghetti " noted in the section is a slender branching coral probably referable to Cladopora and is very characteristic of portions of the upper part of the Nevada limestone of the Eureka district and of the Jefferson limestone cf Montana. In the lower 1,000 feet of the Silverhorn as given digitate Favosites, cyathophylloid corals, and Stromatoporo are occasionally found. At one or two horizons Atrypa reticularis is abundant.

Mr. Kirk comments as follows on the age of the Silverhorn dolomite:

The Silverhorn is of: high (post-Stringocephahus) Middle Devonian age. It may accurately be correlated with the upper balf of the Nevada limestone of the Eureka district (excluding the uppermost, Upper Devonian portion). It is probable that the Jefferson limestone of Montana falls somewhere within this interval.

Fossils and age of the West Range limestone.-The following lots of fossils were collected from the lower part of the West Range limestone of the Silverhorn section, as determined by Edwin Kirk:

18 KIrk, Ddwin, New American occurrences of Stringocephalus: Am Jour. Scl., 5th ser., vol. 13, p. $220,1927$.
Lot $1080 . \quad 4,500$ feet $\mathbf{S} .77^{\circ}$ W. from Scotty Spring:

Athyris angelica.

Productella sp.

Spirifer whitneyi var.

Camarotoechia contracta.

Lot 1535. 1,500 feet $\mathrm{S}$. $25^{\circ} \mathrm{W}$. from mineral monument No. 225, at the base of the hill on. the west side of Scotty Wash :

Spirifer whitneyi var.

Athyris sp.

Atrypa reticularis.

Bellerophon sp.

The lots listed below were collected in the West hange limestone in the south face of the high hill that lies 4,300 feet northwest of the 6,137 -foot summit in the West Range:

Lot 104:

Acervularia cf. A. palmeri.

Spirifer whitneyi var.

Athyris angelica.

Atrypa reticularis.

Lot 1554:

Pugnax pugnus.

Spirifer whitneyi var.

Camarotoechia sp.

Atrypa reticularis.

Athyris angelica.

Straparollus sp.

Lot 1557 :

Productella sp.

Spirifer whitneyi var.

In the West Range limestone of Dutch John Mountain, north of this district, a small collection of fossils was made. The species were identical with those found at the type locality, as follows:

Athyris angelica.

Pugnax pugnus.

Camarotoechia contracta.

Spirifer whitneyi var.

In regard to the age of the West Range limestone Mr. Kirk states:

The West Range limestone is of Upper Devonian age and correlates exactly with the uppermost portion of the Nevada limestone of the Eureka district. It is of approximately the same age as the lower or Devonian portion of the Ouray limestone of Colorado, the Threeforks shale of Montana, and the Upper Devonian part of the Martin limestone of Arizona.

\section{CARBONIFEROUS SYSTEM}

The following formations, named in descending order, are referred to the Carboniferous:

Bailey Spring limestone.

Scotty Wash quartzite.

Peers Spring formation.

Bristol Pass limestone. 
The three lower formations are Mississippian. The Bailey Spring limestone is upper Mississippian and lower Pennsylvanian.

In the area mapped Carboniferous rocks occur only in the West Range and the hills north and west of Bristol Pass; they are not found in the Bristol Range itself. The formations in this area are generally separated by faults, so that there is some doubt of the stratigraphic succession, but 40 miles north of Pioche, in Dutch John Mountain (see fig. 5), they lie in apparent normal succession.

\section{MISSISSIPPIAN SERIES}

BRISTOL PASS IIMESTONE

The Bristol Pass limestone is here named from its occurrence at Bristol Pass, in the summit of the hill immediately north of bench mark 6149. It seems to lie conformably above the West Range limestone (Upper Devonian) and holds the same position in its outcrop at Silverhorn and at two localities east of Fairview Wash. It is a gray, finely crystalline limestone, with few cherty beds, and is sparingly fossiliferous. The greatest thickness measured (305 feet) was at Dutch John Mountain, but southward along the crest of this mountain higher beds occur that were not measured, so that its full thickness is unknown. Nowhere in the Bristol Range quadrangle is there a section which includes both top and bottom of the formation. (See fig. 5 and section on p. 22.)

The following fossil collections were made in the Bristol Pass limestone of the Bristol Range quadrangle :

From the base of the formation in the West Range:

Lot 5747:

Triplophyllum sp.

Syringopora? sp.

Platycrinus? sp.

Schizophoria sp.

Schuchertella? aff. S. chemungensis.

Chonetes loganensis.

Pustula sp.

Dielasma sp.

Spirifer centronatus.

Spịiferina sp.

Lot 5748:

Cyathophyllum? sp.

Schuchertella? sp.

Chonetes sp.

Lot 5748a:

Chonetes sp.

From the hill on the enst side of Fairview Wash opposite Fox Spring:

Lot 5477 :

Syringopora sp.

Amplexus? sp.

Triplophyllum sp.
Spirifer centronatus. Martinia? sp. Orthonychia sp.

From a point $1 \frac{1}{2}$ miles north of Bristol Pass and half a mile east of Fairview Wash, on the east side of the valley through the hills of Devonian rock:

Lot 6007 :

Syringopora sp. Chonetes loganensis.

Productus ovatus. Spirifer centronatus.

These faunas are assigned by G. H. Girty to the Madison (lower Mississippian) horizon.

The following lots were collected at Dutch John Mountain (see p. 22):

Lot $6006 \mathrm{a}$ :

Syringopora surcularia.

Amplexus? sp.

Triplophyllum sp.

Cyathophyllum sp.

Rhipidomella sp.

Schellwienella? sp.

Schuchertella chemungensis.

Chonetes loganensis.

Camarotoechia aff. C. metallica.

Spirifer centronatus.

Reticularia cooperensis. Spiriferina solidirostris. Ambocoelia? sp. Composita humilis.

Cleiothyridina crassicardinalis. Eumetria verneuiliana.

Euomphalus sp.

Euomphalus aff. E. spergenensis.

Loxonema sp.

Phillipsia sp.

Lot $6006 \mathrm{~b}$ :

Coral n. gen. aff. Syringopora. Cyathophyllum sp.

Favosites n. sp.

Spirifer centronatus.

Lot 6008:

Schuchertella chemungensis. Camarotoechia metallica: Chonetes loganensis.

Lots $6006 \mathrm{a}$ and $6006 \mathrm{~b}$ were obtained near the base of the formation, but 6008 near the top. All are considered of Madison age.

\section{PEERS SPRING FORMA'TION}

Name and character.-The Peers Spring formation is here named from its occurrence in the hills east and north of Peers Spring, 3 miles northwest of Bristol Pass. It is found in a small area southwest of Silverhorn and is well shown in its proper place in the Dutch John Mountain section (p. 18).

The Peers Spring formation shows considerable lithic variation. The most noticeable type is a black dense, fine-grained limestone, much of it gray-white on the weathered surface, very thin bedded, locally almost shalelike in its lamination. Probably. a more common facies, though not so often seen in actual outcrop because it is a softer rock, is a brown calcareous shale that effervesces slightly in warm hydrochloric acid. The formation as a whole weathers easily, so that outcrops are scarce, the surface being covered with fine gray, lavender, or rusty débris. Interbedded in the shale and thin limestones of the lower part of the formation are blue-black limestones, some layers of which are 4 feet thick. These seem to form a transition by intercalation to the underlying Bristol Pass limestone.

The Peers Spring formation in the Bristol Range. quadrangle is separated from the other Carboniferous formations by fault boundaries; in the Dutch John 
Mountain section its stratigraphic position between the Bristol Pass limestone and Scotty Wash quartzite is clearly shown.

Thickness.-The Peers Spring formation east of Peers Spring has a uniform northwest dip and if possible faulting is disregarded has a calculated thickness of over 2,500 feet; but this calculation can claim little accuracy. At Dutch John Mountain the formation is close to 450 feet thick. The thickness may not have been originally the same at the two localities, or there may be an unconformity not otherwise indicated at the base of the overlying quartzite. In the columnar section (fig. 3) the thickness is given as 500 feet, almost certainly an underestimate for the Bristol Range quadrangle.

Fossils and age.-Fossils are uncommon and are mainly found in the thicker layers of interbedded blue limestone. Lot 5479 came from thick blue limestones east of Peers Spring, probably toward the bottom of the formation. It contained the following species:

Triplophyllum sp.

Schuchertella aff. S. chemungensis.

Spirifer aff. S. mysticensis. Spirifer aff. S. grimesi. Euomphalus? sp.

Camarotoechia metallica. $\quad$ Paraparchites? sp.

This lot is assigned by Mr. Girty to the lower Mississippian Madison horizon.

The top of the small hill just east of the road at the northwest corner of the Bristol Range quadrangle yielded the following species, assigned by Mr. Girty to the upper Mississippian:

Lot 5488:

Lithostrotion? sp.

Schizophoria sp.

Productus semireticulatus?

Pustuln? sp.

Lot 5492 :

Ijenestella sp.

Productus ovatus.

Productus semireticulatus.

Composita? sp.

Nucula aff. $\mathbf{N}$. illinoisensis.

Leda sp.

Aviculipecten sp.
Spirifer aff. S. cameratus. Nucula sp.

Leda sp.

Worthenia? sp.

Bellerophon sp.

Phanerotrema? sp.

Orthonema? sp.

Euomphalus sp.

Loxonema? sp.

Orthoceras? sp.
SCOTTY WASF QUARTZITE

The formation here named Scotty Wash quartzite, from the fact that Scotty Wash passes through it east of Silverhorn, is a quartzitic sandstone which apparently conformably overlies the Peers Spring formation and is provisionally correlated with the Diamond Peak quartzite of the Eureka district. ${ }^{10}$ It is found in two areas-the larger one south and east of Scotty Spring and the other west of Silverhorn. The following section was taken $h_{1}$ alf a mile west-northwest of mineral monument No. 225, on the west side of the valley:

10 Hague, Arnold, Geology of the Eureka district, Nev.: U. S. Geol Survey Mon. 20, p. 85, 1892.
Section west of Silverhorn

Bailey Spring limestone.

Scotty Wash quartzite:

Largely covered and represented by surface débris; probably thin-bedded or shaly sandstone, with some quartzitic sandstone at the top...-.-......-

Red-brown quartzitic sandstone, well bedded and at certain levels in beds 4 or 5 feet thick. Banded and cross-bedded. Bottom of formation not shown

Feet

510

695

Probably a somewhat greater thickness occurs east of Scotty Spring, though it would be difficult to get an accurate measurement there. The section at Dutch John Mountain, north of this district, gives a thickness of about 1,000 feet.

The rock is red and breaks down to dark-red débris. Sand grains can be seen with a lens, but the more massive facies are almost a vitreous quartzite in appearance. It is well bedded, and in places the beds are 5 or 6 feet in thickness. Individual beds are closely banded and locally cross-bedded. Ripple marks are seen in some places. The presence of some limestone débris on the terraces that follow softer parts of the formation points to interbedded limestones.

The base of the quartzite is not shown, as it is separated from the lower Mississippian formations by fault contacts. The upper beds lie with apparent conformity beneath the Bailey Spring limestone. The quartzite is without fossils, but its age is known as Mississippian from that of the immediately overlying and underlying fossiliferous limestones.

\section{MISSISSIPPIAN AND PENNSYLVANIAN SERIES}

BAILEY SPRING LIMESTONE

Name and general character.-The formation here named Bailey Spring limestone occurs in several large areas southeast of Bailey Spring, on the west side of the Bristol Range quadrangle, and in smaller masses associated with the Scotty Wash quartzite east of Silverhorn. The best section is that in the hill directly. east of Bailey Spring, where about 2,250 feet (possible faulting being neglected) of dark blue-gray limestone is shown. The lower beds are the thicker, attaining 3 or 4 feet in thickness. Black chert is common, in lenses as much as 6 or 8 inches thick, in smaller, irregular knots, and in thin bands. The basal beds of the formation are not seen in this section. They consist of olive-brown fossiliferous limestone, weathering to reddish débris, which lies immediately above the Scotty Wash quartzite and passes up into gray-black fossiliferous limestone that weathers to mottled red and yellow. These basal beds are found at many places in the Silverhorn area. How much they add to the approximate thickness of 2,250 feet determined east of Bailey Spring is unknown-probably not much. 
Sections.-At Dutch John Mountain, 40 miles north of Pioche, the rocks are unfaulted, and the formations are seen in their normal succession. The section is sketched very roughly in Figure 5. The Devonian section (p. 18) was measured at the north end of the mountain. The beds dip to the south, so that the Bristol Pass limestone, which caps the hill at its north end, comes down to the mountain base at its south end. Just south of Dutch John Mountain, across a transverse valley, is another range that shows the Carboniferous formations in normal succession in its north slope. The columnar section here is as follows:

$$
\text { Section near Dutch John Mountain }
$$

Bailey Spring limestone: Thick ledges of gray fossiliferous limestone, in places cherty. Fossil lot 6009 was taken on the middle of the slope; lot $6009 \mathrm{a}$ at the summit. At the base, just above the quartzite, is a reddish crystalline fossiliferous limestone, with abundant Spirifers (lot 6008). The southward dip of the rocks in the nearly level-topped ridge gives a much greater thickness than can be obtained at the north end of the hill, where only the lower beds show and where the measurement was made

Scotty Wash quartzite: Red quartzitic and shaly sandstone, the thicker ledges making benches along the slope. In thick ledges near the top the rock is crossbedded and ripple marked and has shaly partings__-_ 1,000

Peers Spring formation: Dense fine-grained coal-black limestone weathering rusty or gray-white, breaking down to flat slabby débris. A few beds of soft sandstone and layers of banded chert

Bristol Pass limestone:

At south base of Dutch. John Mountain (upper beds) : Gray crystalline limestone like that at the top of the Dutch John Mountain section (p. 18). Fossiliferous (lot 6008). The gray limestones become finer grained and darker toward the contact with the overlying Peers Spring formation.(Break in section.)

In north slope of Dutch John Mountain (lower beds) :

Gray crystalline limestone, with some black chert. Fossil lot $6006 \mathrm{a}$

Same. Fossil lot 6006

Gray crystalline limestone in heavy indistinct beds. Fossil lots $6006 \mathrm{~b}, 6006 \mathrm{c}$

West Range limestone (Upper Devonian).

Fossils and age.-There is some question as to the age of the different parts of the Bailey Spring limestone: The following fossil lots were collected at Dutch John Mountain:

Lot $6009 b$. Just above the Scotty Wash quartzite: \begin{tabular}{l|l} 
Spirifer rockymontanus. & Composita subtilita.
\end{tabular} Spiriferina aff. S. transversa.

Lot 6009 . Several hundred feet above the quartzite: Chaetetes milleporaceus. Triplophyllum sp. Fenestella sp. Rhombopora lepidodendroides. Chonetes n. sp.

Productus cora.

Productus semireticulatus.
Lot 6009a. $\quad 700$ feet above the quartzite:

Syringopora multiattenuata. $\mid$ Productus pertenuis.

Triplophyllum sp.

Stenopora n. sp.

Fenestella sp.

Pinnatopora sp.

Ihombopora lepidodendroides.

Productus cora.

Productus semireticulatus.

Productus sp.

Productus n. sp. aff. P. semistriatus.

Spirifer rockymontanus.

Spiriferina n. sp.

Hustedia mormoni.

The two upper lots are considered by G. H. Girty undoubtedly Pennsylvanian. The lower is doubtful but seems rather Pennsylvanian than Mississippian.

In the Bristol Range quadrangle the reddish limestones just above the quartzite yielded lots 5486,5490 , and 5491. Lots 5478,5480 , and 5481 seem to be low in the series; lots 5479,5483 , and 5484 are apparently higher. The species in these lots are as follows:

Lot 5486. Above the quartzite 1 mile east of Scotty Spring: Productus ovatus. Productus parvus. Productus semireticulatus var. Avonia aff. A. arkansana.

Diaphragmus elegans. Diaphragmus elegans var. Spirifer increbescens var.

Lot 5490. Same locality as 5486:

\begin{tabular}{l|l} 
Rhipidomella n. sp. & Diaphragmus elegans.
\end{tabular}

Avonia aff. A. arkansana. Marginifera sp.

Productus semireticulatus var Composita sp.

Productus ovatus.

Lot 5491. Immediately above the quartzite 1 mile west of Silverhorn :

Chaetetes radians?

Triplophyllum sp.

Crania sp.

Productus ovatus.

Productus aff. $P$. inflatus.

Avonia aff. A. arkansana.

Diaphragmus elegans.

Diaphragmus elegans var.

Camarotoechia purduei var. agrestis.

Spirifer increbescens.

Spiriferina spinosa?

Ambocoelia? sp.

Composita subquadrata.

Cliothyridina sublamellosa.

Platyceras sp.

Lot 5478. Just east of Bailey Spring:

Cyathophyllum subcaespito- $\mid$ Productus aff. P. semireticusum?

Stenopora sp.

Fenestella sp.

Streblotrypa? sp.

Rhipidomella nevadensis?

Schizophoria n. sp.

Pustula? sp.

Avonia aff. A. arkansana. latus? Spirifer increbescens var. Dielasma sp.

Spiriferina n. sp. Composita subquadrata. Cliothyridina sublameliosa. Pteria sp.

Lot 5480. Above the quartzite, 11/3 miles southeast of Bailey Spring, at east base of hill marked by bench mark 6658 :

Productus ovatus.

Diaphragmus elegans?

Avonia aff. A. arkansana? Spiriferina sp. Composita sp. Nucula sp.

Spirifer increbescens var. Ostracoda.

Lot 5481. South slope of same hill as lot 5480: Cyathophyllum subcaespitosum?

Lot 5479. Summit of hill 0.7 mile east of Bailey Spring: Cyathophyllum subcaespito- $\mid$ Rhombopora sp. sum?

Stenopora sp.

Fenestella sp.
Productus semireticulatus. Spirifer aff. S. increbescens. 
Lot 5483. Top of hill 1.4 miles west of mineral monument No. 225 at Silverhorn:

\begin{tabular}{l|l} 
Avonia aff. A. arkansana. & Cliothyridina sublamellosa.
\end{tabular}

Diaphragmus elegans?

Lot 54S4. Half a mile west-sonthwest of locality 54S3: Fenestella sp. Rhombopora sp. Streblotiypa? sp.

Productus parvus? Diaphragmus elegans? Cliothyridina sublamellosa.

These faunas are considered upper Mississippian by Mr. Girty.

Two lots of fossils taken from a hill just east of the road 0.7 mile south of Bailey Spring are undoubtedly Pennsylvanian. The rock is a dark blue-gray, rather thick-bedded limestone, not unlike the Mississippian east of Bailey Spring. As the area is completely surrounded by lava, the structural relations of the limestone to the other Paleozoic rocks can not be made out. The calculated thickness is 700 feet. At the north end of the hill some quartzite shows. The following fossils were obtained:

Lot 5483, at the bottom of the section:

Textularia sp.

Fusulina sp.

Syringopora sp.

Chaetetes milliporaceus.

Campophyllum aff. C. kan-

Lot 5482, at the top of the section:

Trusulina sp.

Triplophyllum? sp.

Campophyllum aff. C. kan- Marginifera splendens. sasense.

Syringopora sp.

This identification of the fossils collected above the Scotty Wash quartzite raises a problem as to the age of the Bailey Spring limestone. At Dutch John Mountain fossils collected a few hundred feet above the quartzite are undoubtedly Pennsylvanian, and those just above the quartzite seem to be Pennsylvanian rather than Mississippian. In the Bristol Range quadrangle, however, the lots taken above the quartzite are upper Mississippian, and unless the section is complicated by faulting, which may very well be the truth of the matter, the upper Mississippian extends for 2,000 feet above the quartzite. So far as lithologic characters go, it was found impossible to subdivide the limestones above the Scotty Wash quartzite, which were therefore put into a single formation and named Bailey Spring limestone.

The explanation of the paleontologic contrast may be as follows. The Bailey Spring limestone is in its lower part upper Mississippian, in its upper part Pennsylvanian. Even at that there seems to be a much greater thickness of Mississippian above the quartzite in the Bristol Range quadrangle than at Dutch John Mountain. This may be due to an original difference in thickness of the lower part of the limestone in the two localities, which is not very likely, or to an increase of the measured thickness at Bailey Spring by faulting; or there may be an unconformity within the Bailey Spring limestone, not recognized in the field on structural or lithologic grounds, which at Dutch John Mountain cuts out most of the Mississippian and allows the undoubted Pennsylvanian to come down close to the quartzite. No more definite statement can be made without further and very detailed field study.

\section{Mr. Girty writes:}

The problem presented by the age of the Bailey Spring limestone is impressive and at the same time unsolved. The fossil evidence seems to be quite conclusive that the lower beds in one area have a Chester (upper Mississippian) fauna and in another area a quite different fauna that is Pennsylvanian in age. I wonder if there may not be two quartzites referred to as Scotty Wash quartzite, the one that occurs in Dutch John Mountain, which is 1,000 feet thick, not appearing in the Pioche district, where the only known Pennsylvanian is faulted in; and the Mississippian quartzite of the Pioche district, which is only about half as thick as the other, being represented in Dutch John Mountain by less clastic beds of upper Mississippian age. This explanation has difficulties, I know-difficulties that are less apparent to me than to $\mathrm{Mr}$. Westgate-but I certainly dislike to see an apparently flat contradiction go on record without at leist a plausible explanation.

\section{TERTIARY SYSTEM}

PLIOCENE (?) SERIES

PANACA FORMATION

General field relations.-The Panaca formation, named by Stock ${ }^{20}$ from exposures about Panaca, includes a series of water-laid tuffs of probable Pliocene age, well shown in the badlands east and west of Panaca and lying to-day in essentially the same position as when they were deposited. They are exposed only in Meadow Valley and its tributary Patterson Wash, for these valleys have an outside drainage to the Colorado River, and in them only have the present streams cut through the modern wash and revealed the underlying Tertiary valley filling. The best exposures of the beds (see pl. $5, C, D$ ) are in the south half of the Ely Range quadrangle, where they are well shown in the broad valleys cut by the tributaries of Meadow Valley and where a typical badland topography is developed. Farther north, northeast of Pioche, the formation appears in places along the faces of the valley terraces. Here the valleys are shallower, the slopes are generally mantled with wash from higher levels, and exposures are much less satisfactory. It was impracticable to map in detail the Panaca deposits of this part of the valley; only the more conspicuous exposures along the face of the terraces are shown. It is believed that all of the valley east of the Bristol-Highland Range is underlain by the Panaca tuffs, from the south border of the Highland and Ely Range quadrangles north to the head

${ }^{20}$ Stock, Chester, Late Cenozoic mammalian remains from the Meadow Valley region, southeastern Nevada: Geol. Soc. America Bull., vol. 32, p. 147,1921 . 
of Patterson Wash, beyond the northern limit of the Bristol Range quadrangle. Dry Lake Valley, west of the Bristol-Highland Range, has an interior drainage, and modern wash covers its surface, concealing any underlying deposits.

The present altitude of the Panaca formation ranges from 4,600 to 5,800 feet. It is lowest at the south edge of the Ely Range quadrangle, at the level of the Meadow Valley wash. About 7 miles to the east it is 500 feet higher ( 5,100 feet); to the west, in the Highland quadrangle, the highest exposures on the Bennett Springs road are 600 feet higher (5,200 feet). At the north edge of the Ely Range quadrangle north of the Spring Valley road, the Panaca formation is found at an altitude of 5,800 feet, 300 feet above the level of the adjacent flat of Lake Valley. Meadow Valley drops to the south beyond the limits of the mapped area, and the Panaca is exposed along its course to the point where it enters the gorge section above Caliente.

Petrographic character.-The beds of the Panaca formation range from snow-white through cream-color and brown to terra cotta, but the most common color is a light brown. Where changes in color take place vertically they are widely spaced, and color bands along the sides of the valley are broad. In grain the tuffs range from an almost impalpable powder to sand. Small, scattered fragments of volcanic rock and narrow bands of such fragments in which the fragments average an inch or more in diameter occur in the tuffs. The beds range in coherence from loose powder through rock that can be completely powdered by the fingers (the usual type) to coherent rock of sandy or porcelainlike texture.

The tuffs, which at first sight seem massive and thick bedded, on closer inspection are seen to be stratified and water-laid. In a few places they are distinctly bedded and even cross-bedded. Coarser layers of sandy material lie interbedded in the finer-grained material; locally these sandy layers are 2 to 5 inches thick. There are lines of interbedded angular pebbles of volcanic rock that reach rarely 1 inch in diameter, or in extreme cases 6 inches. No fragments were seen at all comparable in size with the rocks in the surface wash. About 2 miles north of Panaca the tuffs lie against a $30^{\circ}$ slope of Cambrian limestone. For some 5 feet above the contact the tuffs contain angular limestone débris derived from the Cambrian beds, and thin horizontal layers of the same material trail out into the tuffs for 100 to 150 feet. Yet at this place the tuffs are in the main massive cliffs of fine-textured lightbrown rock, separated by few lines of stratification and overlain by better-bedded white tuffs.

A bed of white fine-grained, almost massive diatomaceous tuff has been mined by short tunnels at several points a mile east of Panaca. Along one parting plane in this bed are sandy lenses, reaching a maxirium length of 4 feet and a maximum thickness of 8 inches. Along the hill to the west, at a slightly higher horizon, the tuffs are buff and cross-bedded and range from fine silt to gravel one-fourth to one-half inch in diameter. What appear to be rolled silt balls as much as 8 inches in diameter are found here.

Specimens were sifted through a 100 -mesh sieve and examined under the microscope. The following classes of constituents were found:

1. Minèral fragments, commonly angular and fresh, mainly plagioclase but also quartz, hornblende, and biotite. These fragments are angular and show little if any mechanical wear.

2. Fragments of glass, some vesicular and pumiceous, some nearly opaque with inclusions.

3. Aggregates of chalcedony.

4. Grains and granular aggregates of carbonates, chiefly calcite (about one-half of the specimens show effervescence in acid).

5. Diatoms. One-half of the specimens studied showed diatoms, and a quarter had them in large numbers.

The mineral fragments are evidently primary and not derived from the weathering of earlier igneous rocks. The structural features noted above show them to be water-laid. The diatoms indicate shallow ponds, local and temporary, over the surface of the rising flats and are found most abundantly in the more silty parts. The carbonates may be chemical precipitates contemporary with the formation of the tuffs, or, more likely, later calichelike deposits by ground water.

Concretions.-Concretions are found in the middle and upper parts of the Panaca tuffs in the buttes in the northern part of the village of Panaca. They cccur as dark flinty bodies, rounded or oval in vertical section, over a foot in maximum thickness, and passing into irregular bands. Near the summit of the hill is a zone 8 feet in thickness in which the concretions are especially abundant. The inclosing green-gray to white tuffs are fine grained to sandy and contain an abundance of diatoms.

The concretions are gray or brownish gray and porcelainlike and break with a conchoidal fracture. Some are marked with small irregular areas or stringers of black flinty material.

The microscope shows the same angular mineral fragments, granular carbonate aggregates, etc., that are found in the tuffs. These materials lie in a brownish matrix which is largely secondary hydrous silica (opal). The small black stringers are the siliceous fillings of the small openings found in the consolidated but otherwise unaltered tuffs.

Thickness.-It is impossible to give a close estimate of the thickness of the Panaca formation. Valleys cut 100 to 200 feet into it do not reach the underlying rock. North of Panaca the beds rise from the valley level nearly to the top of the Pioche Hills south of the canyon and are thus at least several hundred feet thick. 
Position of beds.-The tuffs dip gently from both sides toward the axis of the present valley. Dips of $4^{\circ} \mathrm{E}$. were noted on the west side of the valley below Bennett Springs. East of Panaca, along the southern border of the quadrangle and on the east side of the valley, the beds are broadly and very gently undulating, locally with a slight dip to the east. This points to a slight warping since their formation but not enough in most places to reverse the gentle original slope toward the middle of the valley. The general horizontality of the Panaca beds shows that they were laid down in a broad valley under topographic conditions essentially like those of to-day. The bedrock topography of the Pioche region has not changed appreciably since pre-Panaca time.

Age.-Stock ${ }^{21}$ records mammalian fossils from the Panaca formation near Panaca. He writes:

The mammalian fauna consists of a camel, possibly Pliauchenia, an advanced type of horse related either to Pliohippus or to Equus, and a rhinoceros. The fauna suggests that the deposits are of Pliocene age. The mammal-bearing sediments of Meadow Valley may be known as the Panaca beds.

No fossils were found during the present study except the diatoms. Samples of tuffs containing diatoms were submitted to Dr. Albert Mann, of the Carnegie Institution, whose report is as follows:

I have made a careful examination of the material from the Pioche district of Nevada.

Sample 173. Light cream-brown consolidated tuff half a mile south of Bennett Springs, Highland quadrangle. Very scanty in diatoms; one species, Denticula elegans, the variety called by Kutzing $D$. thermalis. The mineral matter is tabular flakes (quartz ?) not waterworn.

Sumple 182. Gray-white powdery tuff from butte on the north edge of Panaca village. Rich in diatoms, which are slightly corroded by the action of alkaline water. Mineral matter similar to former but with some waterworn grains, indicating more or more violent transportation than sample 173.

Amphora libyca. Amphora proteus. Cymbella cesatii. Cymbella cymbiformis.

Cymbella turgida.

Denticula elegans.

Epithemia argus.

Eplthemia gibberula.

Epithemia sorex.
Fragilaria brevistriata. Fragilaria construens. Navicula major. Navicula radiosa. Navicula sculpta. Nitzschia palea. Rhopalodia gibba. Synedra capitata.
Sample 183. Gray-white powdery tuff, same locality as 182. Composed of fine, waterworn sand. Diatoms very rare.

Navicula radiosa.

Rhopalodia gibba.

Sample 1563. White friable powdery tuff, from mine in white Pliocene [?] 1 mile east of Panaca. Diatoms largely broken by pressure; somewhat corroded, indicating action of alkaline

a Stock, Chester, Late Cenozolc mammalian remains from the Meadow Valley reglon, southeastern Nevada: Geol. Soc. America Bull., vol. 32, p. $146,1921$.

$$
88276-31-3
$$

water; also with misshapen individuals, indicating alkaline state of water during growth.

Cocconeis placentula.

Cymbella casatii.

Cymbella cymbiformis.

Cymbella ehrenbergii.

Cymbella lanceolata.

Cymbella lunula.

Denticula elegans.

Fragilaria construens, var (=F. harrisonii).

\author{
Gomphonema lanceolatum. \\ Mastogloia grevillei. \\ Navicula bohemica. \\ Navicula elliptica. \\ Navicula major. \\ Navicula viridis. \\ Rhopalodia gibba.
}

Sample 1566. White friable powdery tuff, from mine in white Pliocene [?] just west of 1563. A high per cent diatom earth; mixed with a small amount of fine sand, slightly waterworn.

Cocconeis placentula.

Cymbella americana.

Cymbella cymbiformis.

Cymbella ehrenbergii.

Cymbella mexicana.

Denticula elegans.

Epithemia sorex.

Fragilaria brevistriata.

Fragilaria construens, typica]

and var. (=F. harrisonii).

\author{
Melosira distans. \\ Navicula anglica. \\ Navicula elliptica. \\ Navicula menisculus. \\ Navicula nobilis. \\ Navicula rupestris. \\ Navicula semen. \\ Navicula viridis. \\ Rhopalodia gibba. \\ Surirella ovalis.
}

Sample 1583. Light-brown consolidated sandy tuff, north edge of Ely Range quadrangle, sec. 29 , T. 2 N., R. 68 E. Diatoms very scarce, one species, Denticula elegans. Fine silt and sand, angular, not waterworn.

All the diatoms recorded are strictly fresh-water species.

As to drawing any trustworthy conclusion from the foregoing as to the geologic period of these strata, I have little to say; nor is there any article known to me of service in making a safe interpretation. I can merely state that a little over half the species here recorded are abundant in the fossil deposit at Montgomery, Ala., which has been assigned to the Pleistocene. I do not know that they may not equally well be referred to the Pliocene. The fact is there has been for years an urgent need of fixing the geologic horizons of our vast American fossil diatom beds. But until that is done there will be little chance of making effective use of these persisting and significant fossil remains, the diatoms.

The general history indicated by the facts above set forth is as follows: Immense quantities of volcanic dust and sand were washed into the upper Meadow Valley until the accumulating deposits covered the south end of the Ely Range. After the cessation of tuff accumulation, the streams began washing coarse gravel from the adjacent mountains, covering the tuffs with a veneer of alluvial-fan material, thicker nearer the mountains, thinner near the axis of the valley. Soon the main streams began to cut down into the valley filling.

Two features then came into existence. First, in certain places the new streams found themselves sliperimposed on rock ridges and began to excavate canyons in the older and harder rocks. The best example is Condor Canyon, which is followed by the railroad between Panaca and Pioche, and its tributary Hamlight Canyon. The gorge above Caliente, fol- 
lowed by the same railroad, is of similar origin. The earlier stream circled the south end of the Ely Range. The course of the earlier valley farther south, beyond the mapped area, has not been traced.

A second feature of the later erosion period is the succession of terraces cut into the body of the tuffs, each terrace becoming veneered with a layer of coarse gravel, in part brought from the mountains but in larger part a redeposit of the material on the higher terraces cut away in the formation of the newer and lower flats. In many places slide gravel from the higher levels conceals the Panaca slopes connecting successive levels.

\section{QUATERNARY SYSTEM}

VALLEY ALLUVIUM

The lower parts of the area are filled with outwash from the mountains. Near their bases the slopes are steeper, reaching a maximum gradient of 450 feet to the mile $\left(51 / 2^{\circ}\right)$; away from the ranges the slopes flatten until in Dry Lake Valley, 6 or 7 miles from the mountains, they merge in the almost perfectly level mud flat. The size of material varies with the steepness of slope and distance from the mountains. In Meadow Valley below Panaca rolled blocks of quartzite, limestone, or lava over 2 feet in diameter are found near the base of the range. On the playa flat of Dry Lake Valley the material is fine silt.

In Lake Valley and Meadow Valley there is outside drainage to the Colorado River, and the streams have cut deeply into the wash, which is seen to be a relatively thin veneer covering the underlying valley fill, and redistributed it on successively lower and younger terraces. On the lower terrace east of Panaca the gravel is but 5 feet thick; near the Newman ranch, southwest of Panaca, it is 8 to 20 feet thick; and back toward the mountains there are valleys which cut 125 feet below the general wash level but have not reached the Tertiary.

The gravel is not usually cemented below the surface, but in places the upper few feet is cemented to a conglomerate or breccia that locally makes a hard pavement level with the general surface of the wash. In one or two places south of the Pioche Hills and west of the Panaca-Pioche road loose débris of moderate size makes a stony pavement a single layer of pebbles thick, resting on fine tuffs. There has here been concentration of pebbles during the production of the flat surface on the Panaca deposits.

\section{IGNEOUS ROCKS}

The igneous rocks of this district include great thicknesses of surface lavas and tuffs, covering large areas, and intrusive stacks and dikes. The more recent Tertiary tuffs (Panaca formation) are described separately as sedimentary rocks (p. 23).

\section{TERTIARY (?) LAVAS}

GENERAL FEATURES

Surface lavas cover many square miles in the Pioche district. Their age can not be closely determined within the district itself, because of the absence of sedimentary rocks of approximately the same date. The only earlier sedimentary rocks are those of Paleozoic age, the youngest of which belong to the Pennsylvanian. As the lavas rest unconformably on the Paleozoic limestones they must have been enough later than the Pennsylvanian to permit the tilting and deep erosion of the Paleozoic rocks. They are older than the undisturbed Tertiary tuffs about Panaca (Panaca formation), having been extensively tilted, faulted, and eroded to nearly their present topographic form before the Panaca tuffs were laid down. In previous publications on the geology of the Pioche district ${ }^{22}$ the lavas were referred to as Miocene (?), on the assumption that this was the major period of volcanism in the Great Basin region. However, as lavas in the West Range were involved in the thrust faulting and as in other areas of the Great Basin similar thrust faulting appears to have occurred before Miocene time, ${ }^{23}$ it is considered likely that at least a part of the lavas are of pre-Miocene age.

The lavas of the Blind Mountain area are older than the granitic intrusions but are so highly altered that they can not be identified with those of the rest of the district. On the other hand, at the Hamburg mine there is a dike of dacite of postmineral age (p. 75) which has the same mineral composition as certain of the normal surface lavas.

It is concluded, therefore, that a part of the lavas are of early Tertiary or possibly even of Mesozoic age but that the most recent, being later than the ores and hence also later than the granitic intrusive rocks, may be as young as Miocene.

The extensive erosion on the faulted lavas by which the present surface features of the district were produced must have removed the lava cover from the sedimentary rocks in many places, so that the present area of the lavas is less than it formerly was.

There are several thousand feet of successive lava flows and associated tuffs ranging in thickness from a

22 Westgate, L. G., and Knopf, Adolph, Geology of Pioche, Nev., and vicinity: Am. Inst. Min. and Met. Eng. Trans., vol. 75, pp. 816-836, 1927. Gillson, J. L., Petrography of the Pioche district, Lincoln County, Nev.: U. S. Geol. Survey Prof. Paper 158, pp. 77-S6, 1929.

23 Nolan, T. B., Geology and ore deposits of the Gold Hill district, Utah: U. S. Geol. Survey Prof. Paper - (in preparation). Hewett, D. F., Geology and ore deposits of the Goodsprings district, Nev.: U.S. Geol. Survey Prof. Paper 162, pp. 42-55, 1931. Longwell, C. R., Structural studies in southern Nevada and western Arizona: Geol. Soc. America Bull., vol. 37, pp. 551-584, 1926. 
few feet to 1,000 feet or more and in character from rhyolite to basalt. These lithic extremes are, however, uncommon; by far the greater part of the material is of intermediate composition, an andesite or dacite.

The largest lava area of the district, covering about 45 square miles, is in the northwest quarter of the Bristol Range quadrangle, north and west of Bristol Pass, and extends northward for 10 or 15 miles beyond the edge of the quadrangle. A second large area starts 4 miles east of Pioche and extends southeastward beyond the limits of the Ely Range quadrangle. The upper four-fifths of Condor Canyon is cut through these lavas. A third lava area, consisting of several large discontinuous patches, lies west of the Highland Range, from Blind Mountain to the south edge of the Highland quadrangle. In addition to these three areas numerous smaller occurrences of lava are scattered over the district.

Exposures within the lava areas are poor. The lavas weather readily, as is shown by the fact that all the highest parts of the district are on the Paleozoic sedimentary rocks. Commonly the lavas make rounded hills covered with débris, with scattered outcrops or exposed ledges of the harder flows. The poor exposures over large sections, the locally unrecognizable effects of faulting, and the similarity of successive flows make it very difficult, if not practically impossible, to work out the structure of the lavas in detail. Certainly there is not enough involved to justify the attempt, for nowhere do they carry ores. The lavas are therefore mapped as a unit, and their general structural relations are shown by the structure sections. Although a detailed structural account of the lavas is impossible, a description of the outstanding features of the several areas will give a good idea of the different kinds of flows and of their succession.

\section{CONDOR CANYON SECTION}

By far the best exposed section in the district is that in Condor Canyon. The lower mile of the canyon is in the Highland Peak limestone, which has an average dip of $40^{\circ} \mathrm{E}$. Upstream from the limestone more than 6,000 feet of lavas and tuffs, with an average dip of $25^{\circ} \mathrm{E}$., are exposed in the canyon walls. The measured section shown in Figure 6 ends at the east entrance of the canJon half a mile south of the Delmues ranch. The lavas extend east to the edge of the wash beyond the ranch, but this part is discontinuous with the measured sec- tion, is probably repeated by faulting, and is here disregarded. The following notes on the successive lavas are given in order from below up.

1. Biotite dacite, $S 00$ feet. A lilac-gray rock showing small crystals of quartz, plagioclase, and biotite crowded in a lightred groundmass. The microscope $\mathrm{shows}$ phenocrysts of

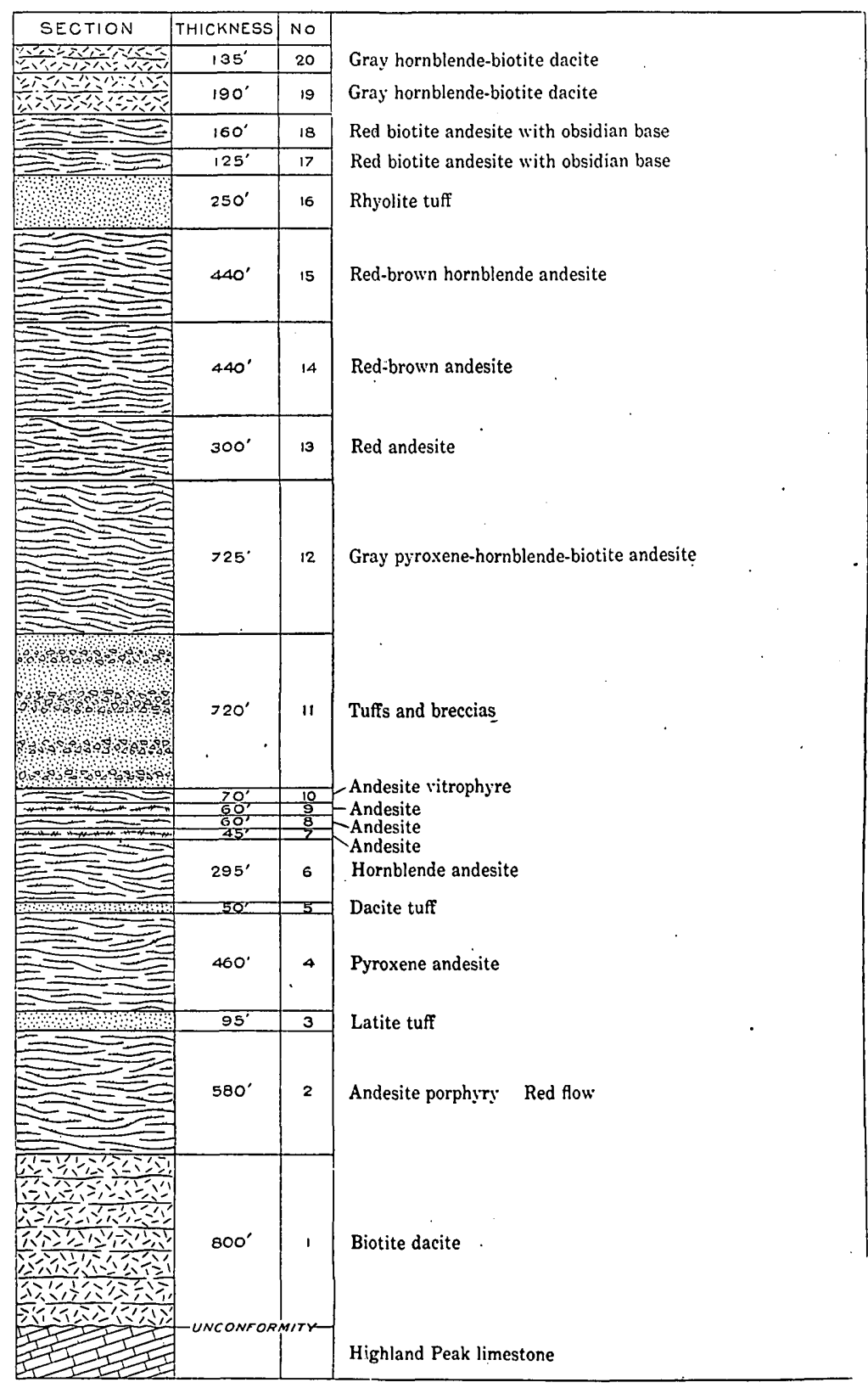

Figure 6.-Columnar section of lavas in Condor Canyun

quartz, plagioclase (andesine), biotite, less ccmmonly lorm blende, and rarely augite. Magnetite, less abundintly api: tite, and in some sections titanite and zircon occur as acces: sory minerals, though the magnetite is so abuudant that it might be considered an essential phenocryst. Quartz occurs in irregular grains or crystals as much as 2 millimetcrs in diameter, many of them corroded and embayed. The bintite is commonly fresh, though in places altered to an aggregate bordered by and containing magnetite. The hornblende generally shows a similar change. The changes in the quirtz, 
biotite, and hornblende are magmatic changes that accompanied the final stages of consolidation of the rock. Weathering changes are insignificant, and the feldspars are commonly fresh. The groundmass is microcrystalline to cryptocrystalline, rendered brown by finely granular iron oxide and other opaque products. Flow structure is present but not conspicuous. Phenocrysts make 50 to 60 per cent of the rock. The ratio of salic to femic minerals is 4 or 5 to 1 . In some slides the hornblende nearly equals the biotite, but usually it is present in much less abundance. The augite is absent in most sections and where present occurs in small amount. No sanidine was seen among the phenocrysts and if present in the groundmass was not recognized. The rock is then a quartz andesite, or dacite. Flow 1 varies somewhat in color but appears to be a single flow. A platy structure parallel to the dip is an effect of flow. This rock is one of the most common types in the district, especially in the Bristol Range and Highland quadrangles.

2. Andesite porphyry, 580 feet. A red-brown rock, showing small indistinct white feldspars in a red-brown aphanitic groundmass. The miscroscope shows feldspar (andesine) crystals as much as $\mathbf{1 . 5}$ millimeters in diameter and irregular grains of magnetite in a cryptocrystalline groundmass of undeterminable material colored with minute granules of iron oxide and streaked with somewhat coarser microcrystalline areas of the same general character. Apatite is present and hematite is common, especially about the magnetite grains. The phenocrysts make less than one-tenth of the rock. The exact rock species can not be determined from microscopic study where so large a part of the rock is undeterminable groundmass. It can be called andesite. Flow 2 rests on the eroded surface of flow 1. It shows three bands, but these are considered parts of one flow.

3. Latite tuff, 95 feet. A pale lilac-gray, finely granular rock containing scattered flakes of biotite, small crystals of feldspar, and subparallel chips of pumice.

The microscope shows sanidine, less abundant plagioclase (andesine), and a little biotite and magnetite lying in a matrix that shows a tuffaceous texture but is now microcrystalline and cryptocrystalline as a result of devitrification.

4. Pyroxene anclesite, 460 feet. Gray to greenish-gray and gray-black rocks, weathering deep brown. Vesicular bands at several levels, the terraced character of the outcrop, and some differences in mineral character indicate that No. 4 is composed of several flows; but as the same general kind of rock occurs throughout, it is treated as a unit. Specimens from the lower part of the flow are fine-grained gray-black rocks with small and indistinct phenocrysts. The microscope shows crystals of plagioclase (andesine-labradorite) as much as 2 millimeters in diameter, pyroxene ( 1 millimeter or less), and magnetite in a groundmass composed of minute prisms of plagioclase and grains of pyroxene and magnetite. Both orthorhombic pyroxene (hypersthene) and monoclinic pyroxene (augite) are present, the first in greater abundance. The groundmass is estimated to form 52 per cent of the rock and the phenocrysts of plagioclase 30 per cent, pyroxenes 15 per cent, and magnetite 3 per cent. Specimens taken nearer the top of No. 4 showed the same general textural and mineralogic characters, except that hypersthene was not seen and some hornblende was present, in part secondary after pyroxene. One slide shows olivine almost wholly changed to serpentine. It is a question whether this rock should be called an andesite or a basalt. It stands in sharp contrast with the other andesites of the district in darker color, more basic plagioclase, abundance of pyroxene (much of it hypersthene), absence of biotite and of primary hornblende, and finer texture of its groundmass. It is, somewhat arbitrarily, put with the andesites.

5. Dacite tuff, 50 feet. A creamy-white rock showing minute flakes of biotite, crystals of feldspar, and a few small lava inclusions in a stony groundmass. The microscope shows quartz as much as 2 millimeters in diameter, plagioclase (andesine), and some biotite in a glassy groundmass that has a tuffaceous structure.

6. Hornblende andesite, 295 feet. Flows 6 to 10 form a series of massive red-brown lavas which extend northeastward as far as the entrance to Hamlight Canyon. Flow 6, the lowest, makes high cliffs of much jointed red-brown finegrained lava which requires a lens to bring out the small hornblende crystals. The microscope shows abundant crystals of deep red-brown hornblende, as much as 2 millimeters in diameter, and magnetite in a vesicular groundmass in which small plagioclase (andesine) laths 0.2 millimeter or less across with subparallel orientation lie in a microcrystalline to cryptocrystalline base containing much granular ferruginous material.

7. Andesite, 45 feet. Terra cotta lava showing in the hand specimen minute feldspar crystals and small patches of pumice. The microscope shows rectangular plagioclase crystals 1 millimeter or less in diameter and grains of magnetite in a vesicular cryptocrystalline groundmass colored deep red by crowded granules of iron oxide.

8. Andesite, 60 feet. Lilac-red lava with small scattered crystals of feldspar. The microscope shows a few large and more smaller crystals of plagioclase and grains of magnetite in a microciystalline or glassy vesicular groundmass with abundant iron oxide granules.

9. Andesite, 60 feet. Like No. 7 but is lighter in color and contains more pumice inclusions. It was not examined in thin section.

10. Andesite vitrophyre, 70 feet. Lilac-gray lava streaked with narrow white plane-parallel bands. The microscope shows scattered crystals of plagioclase, a few grains of magnetite, and a very little biotite in a microcrystalline to cryptocrystalline groundmass containing abundant iron oxide granules. Calcite and aggregates of tridymite occur in irregular patches.

11. Tuffs and breccias, 720 feet. Light-gray to white rocks containing lava fragments 1 foot in maximum diameter.

12. Gray pyroxene-horublende-biotite andesite, 725 feet. Near the bottom it. is a gray lava specked with crystals of black biotite and pyroxene and white plagioclase. The microscope shows plagioclase (andesine) reaching 3 millimeters in diameter, biotite 2 millimeters, olive-green hornblende 1 or 2 millimeters, green pyroxene 3 millimeters, and grains of magnetite in a glassy, slightly clouded groundmass. One small grain of quartz was seen. The ratio of constituents is estimated in percentages as plagioclase, 50 ; biotite, 6 ; hornblende, 5 ; pyroxene, 4 ; glass, 25.

13. Red andesite, 300 feet. Lilac-red lava, slightly vesicular, spotted with small feldspar crystals. No thin section. The rock is very similar to flow 2 .

14. Red andesite, 440 feet. Weathering red-brown.

15. Red-brown hornblende andesite, 440 feet. Fine-grained red lavas north and south of the water tank. The same as flow 6.

16. Rhyolite tuff, 250 feet thick on the railroad, thickening northward and thinning to a few feet or nothing on the south side of the valley. It is not clear whether this thinning is due to faulting, to deposition of the tuffs on an uneven surface, or to erosion after deposition and before the outflow of the succeeding lava. The second explanation is the more 
likely. A hand specimen is a light ll1ac-brown rock with abundant phenocrysts of quartz and feldspar, a few crystals of biotite, and many shreds of pumice. The microscope shows abundant quartz in irregular grains 1.5 to 2 millimeters in diameter, sanidine and plagioclase, the first much more abundant, and a little biotite and magnetite in a glassy groundmass showing tuffaceous structure.

17. Red blotite andesite with obsidian base, 125 feet. The basal 10 or 12 feet of this flow is a black obsidian porphyry, a black glass specked with phenocrysts of feldspar. The microscope shows rectangular crystals of plagioclase (andesine) as much as 1 millimeter in diameter but commonly smaller, with some biotite and magnetite, in a glass dark with crowded granules. The phenocrysts make about onetenth of the rock. The obsidian passes abruptly into the main red-brown rock, which shows in the hand specimen small crystals of feldspar and biotite in a brown porcelainlike base. The microscope shows small crystals of plagioclase measuring 1 millimeter or less, biotite as much as 5 millimeters, and magnetite in a cryptocrystalline groundmass crowded with crysts, in greatest part feldspar, make up about 20 per cent of the rock. Flow and vitroclastic structures are visible.

19. Gray hornblende-biotite dacite, 190 feet. Gray lava, on hasty inspection resembling a granite, making massive ledges in the canyon. The hand specimen shows abundant crystals of quartz, plagioclase, biotite, and hornblende in a white groundmass. No thin section was examined.

20. Gray hornblende-biotite dacite, 135 feet. This flow, which is double, consisting of a lower layer 45 feet thick and upper one 90 feet thick, makes the dip slope at the entrance to the canyon. The rock is much streaked with small pumice inclusions, which weather out, making pits. The hand specimen is a medium-grained gray rock with abundant crystals of quartz, feldspar, biotite, and hornblende in a gray groundmass. The microscope shows numerous quartz grains, plagioclase, sanidine, biotite, hornblende, and magnetite in a glassy or cryptocrystalline groundmass crowded with small granules. The phenocrysts make one-third to one-half of the rock. The plagioclase is much in excess of the sanidine, and the biotite of the hornblende.

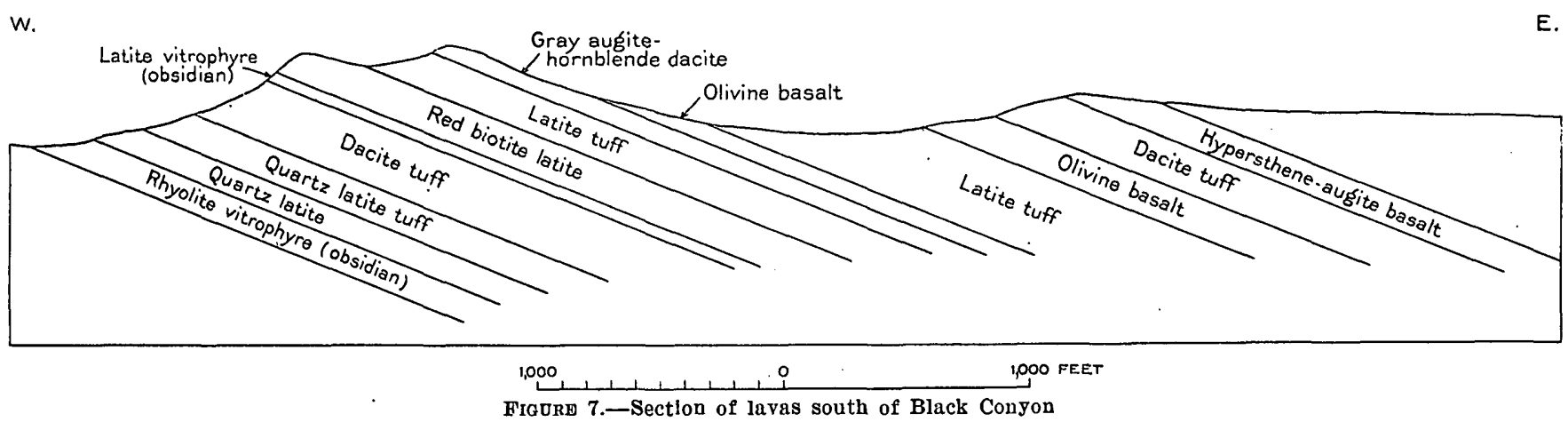

minute granules. This rock does not differ mineralogically from the obsidian at its base. It has a distinct flow structure. Lighter-colored microcrystalline bands contain tridymite.

Alternations of vesicular with compact lava through the flow indicate that it may be a composite.

Spherical bodies as much as 15 inches in diameter are found mainly at the transition of the obsidian to the overlying red andesite and in lesser numbers down to a horizon 2 feet below the transition zone. They are dark on the outside and prevallingly red within, or show rudely concentric alternations of the two colors. There is commonly an irregular central opening llned with chalcedony and in some more centrally with calcite.

18. Red biotite andesite with obsidian base, 160 feet. This flow is much like No. 7 , but it is not considered the same repented by faulting. The basal part is a black obsidian porphyry about 12 feet thick, which passes up into a redbrown lava but a little more gradually than in flow 13. At the contact are numerous lenticular nodules reaching a maximum size of 9 inches but averaging 4 or 5 inches. They are distributed vertically through 3 feet of rock and are found in both the obsidian and the red rock. In the main red flow there is an altepnation of several beds of vesicular and compact rock.

A specimen taken just below the top of the brown lavas shows abundant crystals of feldspar and fewer of biotite in a red-brown stony base. The microscope shows plagioclase (andesine) in good crystais as much as 2 millimeters in diameter, biotite, magnetite, and a very few grains of green pyroxene in a cryptocrystalline groundmass. The pheno-
In summary, the following varieties of lava are found in the canyon section:

Lilac-colored hornblende-biotite dacite_- Number of fow Gray hornblende-biotite dacite_........ 19, 20 Red-specked andesite porphyry (few dark minerals) .... 2, 7 , $8,9,13,14,17,18$ Hornblende andesite Gray pyroxene-hornb'ende-biotite andesite____._._._._. 12 Hypersthene andesite..._-_._-_._- 4 TuffS_-_-_._. $3,5,16,11$

Andesite obsidian

10

The same varieties occur in other areas and, in addition, olivine basalt. In the following descriptions only the more general features will be given.

\section{BLACK CANYON SECTION}

A large field of lavas lies at the south edge of the Highland quadrangle between Black Canyon and Klondike Gap. The dip is $15^{\circ}$ or $20^{\circ} \mathrm{E}$. and the strike north-northwest, swinging around to north at Black Canyon. In the hills $1 \frac{1}{2}$ miles west of Klondike Gap the section shown in Figure 7 was taken. The total thickness of the section, judged from width of outcrop and dip, is 2,000 feet, but this represents the thickness of the lavas in this section only, not the total for the area. The approximate thickness of individual 
beds is given for only a few of the members of the series. The sequence from above down is as follows:

13. Hypersthene-augite basalt.

12. Dacite tuff.

11. Olivine basalt, vesicular at top.

10. Latite tuff.

9. Olivine basalt.

8. Gray augite-hornblende dacite.

7. Latite tuff.

6. Red biotite latite.

5. Latite vitrophyre (obsidian).

4. Dacite tuff.

3. Quartz latite tuff.

2. Quartz latite.

1. Rhyolite vitrophyre (obsidian).

Flow 1 is a gray glassy rock, with phenocrysts of feldspar and biotite. It is vesicular and carries inclusions of other lavas. The microscope shows abundant quartz, plagioclase, sanidine, and biotite, with magnetite and titanite, in a glassy groundmass which is in part clear, in part brownish with minute inclusions. The phenocrysts make up about 50 per ward to the north edge of the Highland quadrangle. The flows dip $10^{\circ}-20^{\circ} \mathrm{E}$. and strike approximately north.

The section of lavas east from the east base of the Ely Springs Range at Ely Springs is given in Figure 8. The lower beds, up to a prominent red andesite, are the common lilac-colored biotite dacites, with associated tuffs of similar mineral composition. Part way up in the series is a 15-foot obsidian (biotitehornblende dacite vitrophyre), probably a glassy facies of the overlying biotite-hornblende dacite, and a little below the andesite two flows, augite andesite below and hypersthene-augite andesite above.

The red andesite (augite andesite, 150 feet thick) makes the largest of several parallel ridges. It is a red or red-brown rock with small lenticular inclusions of stony or glassy lava as much as 2 inches across. The hand specimen has a flinty brown-red ground-

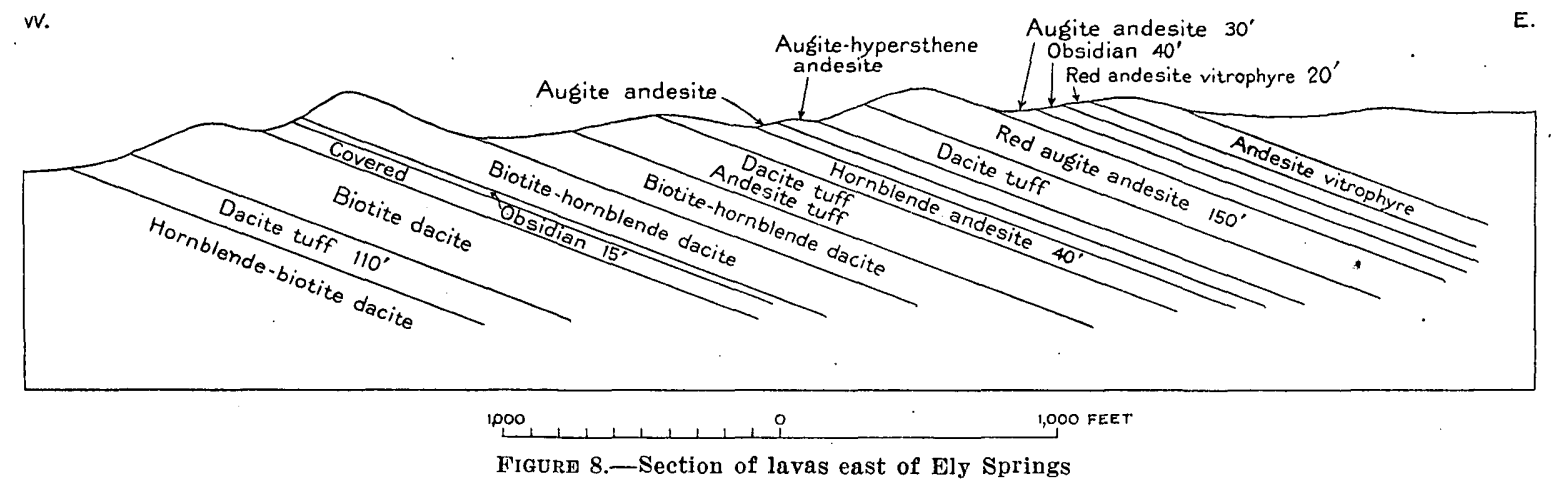

cent of the rock. The salic constituents are much more abundant than the femic, and the sanidine than the plagioclase.

The second obsidian, flow 5 , shows phenocrysts of plagioclase (andesine), sanidine, biotite, green hornblende, a very little augite, magnetite, apatite, and zircon in a brown glassy base. The plagioclase is much in excess of the sanidine. The phenocrysts make up about 25 per cent of the rock. The relation of this obsidian to the overlying red biotite latite resembles that of the two obsidians in the Condor Canyon series to their overlying red lavas.

The two olivine basalts are unlike anything in the Condor Canyon section. The upper basalt (flow 11) is a black aphanitic vesicular rock. The microscope shows as phenocrysts plagioclase (labradorite, a single 1-millimeter crystal), olivine (common, largely in good crystals), and a little augite. The olivine crystals are wholly or partly altered to red-brown iddingsite. The groundmass consists of plagioclase microlites as much as 0.2 millimeter in diameter, in places subparallel, augite, and magnetite. The lower basalt (flow 9) is a grayblack aphanitic rock with no distinct phenocrysts. In the thin section open spaces may represent plagioclases ripped out. Olivine is common. The groundmass contains abundant small prisms of plagioclase, grains of olivine, augite, and magnetite, in a black opaque base.

\section{ELY SPRINGS AND DELMUES WELI SECTIONS}

A lava area, continuous except at the north where its lower parts are covered by wash, lies along the east side of the Ely Springs Range and extends north- mass in which lie small feldspar crystals. The microscope shows plagioclase (andesine), pale-green augite, magnetite, and a little apatite in a deep-brown cryptocrystalline groundmass: Phenocrysts, chiefly plagioclase, make up about 50 per cent of the rock, and there are numerous small inclusions of other lavas.

The red augite andesite is near the top of this section. It makes a ridge along the east side of sec. 26 . T. 1 N., R. 65 E., and can be traced northward to the high hill near the center of sec. 23. From this hill a section was made east along the divide. (See fig. 9.) As the red augite andesite lies at the bottom of this section the flows here lie above those to the south. There is in general a repetition of the rock varieties found to the south, but the augite and hyperstheneaugite andesites are more abundant than in the lower part of the section to the south.

In both of these sections the succession of flows and tuffs is given, but, except for a few of the flows, no attempt is made to give the thickness. The total thickness of the two sections, if there is no repetition by faulting, is about 3,000 feet.

The lavas about Delmues Well dip $10^{\circ}-20^{\circ} \mathrm{E}$. and strike N. $10^{\circ} \mathrm{W}$. They are in line with or a little east 
of the continuation along the strike of the more southern beds.

A conspicuous red andesitic lava makes a line of hills a quarter of a mile east of the $\mathrm{N} .10^{\circ} \mathrm{W}$. road at Delmues Well, including the two hills just north and south of the well. It is a red aphanitic rock which under the microscope shows plagioclase (andesine), a few grains of an unknown femic mineral, and magnetite in a dark-brown vesicular microcrystalline groundmass crowded with minute granules. The phenocrysts make less than one-tenth of the rock and in specimens collected to the north along the ridge are quite lacking. The flow resembles in some ways the main red augite andesite to the south but probably not closely enough to be considered the same rock.

Below (west of) this red andesite and also above it (for a mile east) the most common types of lava are the dark augite and hypersthene-augite andesites biotite (not over 5 per cent of the rock) and magnetite in a red-brown vitroclastic groundmass. Larger .sections of the groundmass are replaced by finely granular chalcedonic quartz; which becomes coarser grained toward the center of the patches. This secondary quartz makes from one-third to one-half of the whole rock.

\section{NORTHWESTERN AREA}

The largest single area of lavas, covering nearly 45 square miles, extends north and west from Bristol Pass. Over much of this area outcrops are poor or lacking. It lies outside that part of the district where a dominant north-south faulting has given a prevailing eastward dip to the rocks; the dip and strike vary widely, and faulting has taken place, but the rock structure was not deciphered. The following general statements are all that can be made.

w.

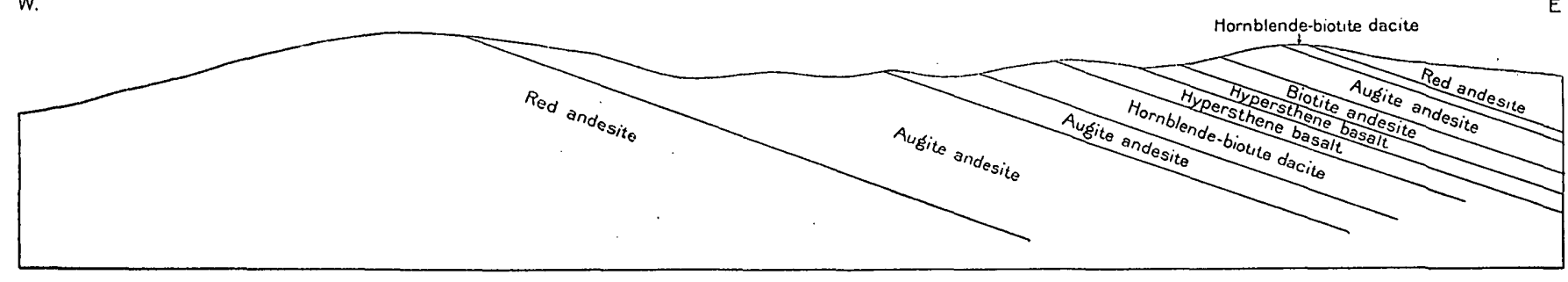
1,000 1,000 FEET

FIGURE 9.-Scction of lavas east of Ely Springs Range

found in the upper part of the series to the south. Interbedded with them are some red andesites. The lavas near Delmues Well probably represent the upper part of the series to the south or are still higher flows.

The high hill 2 miles west of Delmues Well consists of dark-gray augite andesite dipping gently east, whose relation to the rocks of the Delmues Well section is unknown.

The lavas in the southwest quarter of the Highland quadrangle would probably, if the intervening wash cover were removed, prove to be continuous with those south of Black Canyon. South of the Hiko road they are chiefly the common red dacites and andesites. The isolated hills north of the Hiko road for 5 miles north of Monument Canyon contain abundant dacitic and rhyolitic tuffs with some interbedded obsidian or vitrophyre. The general strike is north, and the dip $15^{\circ}-$ $20^{\circ} \mathrm{W}$. These more porous rocks have undergone silicification to an extent unknown elsewhere in the lavas. The three hills at the north reaching altitudes of 4,945 4,877 , and 5,009 feet are on a layer of more or less distinctly tuffaceous andesite. A specimen from the 4,945-foot hill is a red-brown rock with crystals of biotite and plagioclase in a red aphanitic base, irregularly strealked with gray chalcedony. Irregular cavities an inch or less in diameter are lined with crystalline quartz. The microscope shows plagioclase and
That part lying east of the Fairview Range and extending south to the fault north of Upper Fairview Spring is occupied mostly by a thick series of the common lilac-red biotite dacites, with some red andesites. The general strike here is northeast and the dip $15^{\circ}-$ $40^{\circ} \mathrm{SE}$. The summit of the Fairview Range, altitude 7,509 feet, is capped by a flow of black vesicular hypersthene-augite andesite, weathering brown, about 200 feet thick. If there is no faulting this andesite lies beneath dacites to the east. The succession on this peak from the summit down comprises black hyperstheneaugite andesite, red vesicular andesite, gray biotite dacite, and lilac-colored biotite dacite.

The marked and locally abrupt differences in dip and strike of the lavas west of meridian $114^{\circ} 40^{\prime}$ mean that this area as a whole is separated by faults from the area on the east and that it is itself broken by faults into blocks. Some of these faults can be located in part, but it was impossible to make out the structure in any completeness.

A black hypersthene-augite andesite is common and. as it is harder than the associated lavas, caps many of the hills. Whether or not the different exposures represent the same bed separated by faulting is uncertain. The general association of the andesite with the similar red lavas suggests that if not one bed it represents one general horizon. Immediately below the black 
andesite comes a red andesite, 50 feet thick, and then a flow or flows of lilac-red biotite dacite which in the north slope of Fairview Peak is at least 1,200 feet thick. The basalt caps Fairview Peak and many hills about Littlefield Spring and is very common in the hills west of the Ely road between Littlefield and Bailey Springs.

A third part of this northern area, from the eastwest fault north of the Fairview Springs south to the sedimentary rocks about Silverhorn, is occupied by what is in some ways a different and possibly a lower series. The black andesite is absent. The commonest rocks are still the lilac-colored and gray biotite dacites, kut tuffs and pitchstones are conspicuous. A mile southeast of Fairview Peak pitchstone occurs between lilac-colored dacite above and gray dacite below. Two miles due south of Fairview Peak pitchstone is associated with dacite. The rock under the microscope shows phenocrysts of quartz, plagioclase, sanidine, biotite, and magnetite in a glass with well-developed perlitic structure. Along the south side of the ridge north of Lower Fairview Spring is a 100 -foot bed of perlitic pitchstone with some stony bands and inclusions, the bottom of the bed whiter and more chalky because of alteration. The hand specimen is a bluegray glassy rock with indistinct phenocrysts, breaking with a conchoidal fracture but without perlitic structure. The microscope shows, a flow-banded glass crowded with small spherulites from 0.01 to 0.03 millimeter in diameter and with abundant small grains and hairlike inclusions. A very few phenocrysts of plagioclase and biotite are present.

South and west from the area of sedimentary rocks about Silverhorn lava exposures are poor and are commonly dacites.

\section{RELATED DIKES}

At the Hamburg mine (see p. 75) a 5-foot dike of dacite vitrophyre cuts the Mendha limestone. The rock contains abundant phenocrysts of biotite, hornblende, and andesine and a few of quartz in a glassy base; it is so like certain of the lavas that it probably kelongs to the same series. Another dike of dacite vitrophyre, about 30 feet thick, occurs on the Buckhorn claim, half a mile northwest of Pioche; and a dike of related rock occurs 800 feet north of the Alps mine, south of Pioche.

\section{INTRUSIVE ROCKS}

QUARTZ MONZONITE AND ASSOCIATED PORPHYRIES AT BLIND MOUNTAIN 24

The Blind Mountain area of intrusive rocks, shown on Plate 1, lies along the west base of the Bristol Range from a point one-third of a mile north of the

\footnotetext{
"This section, as far as the heading "Associated dike rocks" (p. 35),
} Is contributed by Joseph $\mathrm{L}$. Olllson.
Stampede Gap road as far as Blind Mountain Spring, a distance of 3 miles. The maximum width is nearly a mile, and its eastern boundary is near the base of the steep slope of the main range. This area differs greatly from the immediately surrounding part of the range in the abundance of igneous intrusions, in the high degree of metamorphism of its rocks, and in the fact that the sedimentary rocks within the area, as shown by fossils and lithic character, are of Devonian age, not Cambrian. The structure of both sedimentary and intrusive rocks is so complex that it was not decipherable in detail. The Devonian of the overthrust block is found both to the north and south, and consequently it is believed that this area is a part of this overthrust block let down into the older rocks by normal faulting, the intrusion accompanying the downfaulting.

The igneous rocks within the area comprise quartz monzonite, monzonitic and dioritic porphyries, and lavas, now highly metamorphosed.

\section{QUARTZ MONZONITE}

Distribution.-A granitoid rock approximating quartz monzonite in composition occurs in two areas. The southern area, 11/2 miles long, extends from a point one-third of a mile north of the Stampede Gap road north to a wash-filled valley just beyond the edge of the Highland quadrangle. The other area. less than a mile in length, lies along the west base of Blind Mountain. These two areas are probably connected beneath the wash and extend westward for some distance beyond the base of the range.

Megascopic features.-The granitoid rock is a light gray to pink medium-grained, slightly porphyritic rock, containing quartz, feldspar, and some ferromagnesian minerals, the most conspicuous of which is biotite. The largest mineral grains are about 3 millimeters in diameter. The coarser facies of the porphyritic rock contain white plagioclase phenocrysts as much as 2 millimeters in diameter and less abundant dark-colored phenocrysts of the same size, set in a dark groundmass. Quartz is not recognizable by the naked eye except in the coarsest parts, as it occurs only in the groundmass. The finer-grained facies are found in the several apophyses of the mass, and they contain numerous glassy plagioclase phenocrysts reaching a: diameter of 1.5 millimeters set in a dark-colored aphanitic groundmass.

Associated aplite dikes are light-colored fine-grained rocks in which dark silicates occur only as scattered crystals.

Large masses of true pegmatite do not occur, but several small miarolitic cavities were found in which are well-formed crystals of tourmaline, feldspar, and magnetite. In the endomorphosed quartz monzonite narrow pegmatite stringers are abundant. Locally 
these open up into larger druses in which euhedral crystals of quartz and microcline as large as 9 centimeters are found.

In many places small druses containing crystals of epidote and garnet and veinlike stringers of these minerals occur. These belong to a late stage of mineral formation.

Petrography.-The rock away from its margins is subporphyritic and hypidiomorphic in texture and contains the following minerals, in about the proportions shown in the table.

Mineral composition of quartz monzonite

\begin{tabular}{|c|c|c|c|}
\hline & 1 & 2 & 3 \\
\hline $\begin{array}{l}\text { Quartz } \\
\text { Microcline. } \\
\text { Plagioclase. } \\
\text { Biotite. } \\
\text { Hornblende. } \\
\text { Augite. } \\
\text { Accessories... }\end{array}$ & $\begin{array}{l}15 \\
25 \\
46.5 \\
9 \\
2 \\
\text { Rare. } \\
2.5\end{array}$ & $\begin{array}{r}16 \\
22 \\
49 \\
6 \\
3 \\
2 \\
2\end{array}$ & $\begin{array}{r}25 \\
32 \\
35 \\
4 \\
2 \\
-2\end{array}$ \\
\hline
\end{tabular}

1. South slope of McCullough Hill. (Seo pl. 1, 1.)

2. North slope of 7,106-foot hill. (See pl. 1,2.)

The augite occurs as cores of the hornblende grains. The accessories are apatite, magnetite, zircon, allanite, and titanitc. Many of the grains of these minerals are probably cleuteric (formed during the later stages after the rock as a whole had crystallized)-an inference suggested by their shapes.

The rock making up the border portion of the intrusive mass, if. taken where it is almost free from endomorphic effects, is in general similar to the normal type, but it is richer in dark minerals, especially in pyroxene. The mineral composition of the border rock is as follows :

\begin{tabular}{l|r|r|r}
\multicolumn{1}{|c|}{ Mineral composition of border facies of quartz monzonite } \\
\hline
\end{tabular}

1. South slope of McCullough Hill. (See pl. 1, 4.)

2. North slope of hill. (See pl. 1, 5.)
3. East slde of northern area. (See pl, 1, 6.)

This border facies is interpreted as being a chilled margin, representing the composition of the rock magma earlier in the process of differentiation than that shown by the normal type. Hypersthene is almost as abundant as augite in some specimens of the border rock. In places the border facies occurs as a belt of pyroxene diorite porphyry 75 feet wide, which merges by imperceptible gradations into the normal granitic rock of the interior part of the mass. In this jorphyry the phenocrysts are so closely crowded that the sparse groundmass can be seen only under the microscope.

There is considerable variation in mineral composition in specimens taken from points within the area, and there is a question whether the rock as a whole should be called quartz monzonite or granodiorite. In the first table above Nos. 1 and 2 are granodiorites and No. 3 is a quartz monzonite. In the second table all three representatives of the border facies are best called granodiorites. Some thin sections of the normal rock from the interior of the area show orthoclase or microcline in excess of the plagioclase, and one from the east side of McCullough Hill has very little plagioclase and is a typical biotite granite. The average composition of the rock body as a whole is represented fairly well by calling it quartz monzonite.

Only the granitoid facies of the quartz monzonite has been analyzed. The results are as follows:

\section{Analysis of the granitoid facies of the quartz monzonite of Blind Mountain}

[J. G. Fairchild, analyst]

\begin{tabular}{|c|c|c|c|}
\hline Analysis & & Norm & \\
\hline $\mathrm{SiO}_{2}$ & 65.84 & Quartz & 20.64 \\
\hline $\mathrm{Al}_{2} \mathrm{O}_{3}$ & 15. 29 & Orthoclase & 26.6 \\
\hline $\mathrm{Fe}_{2} \mathrm{O}_{3}$ & 2.48 & Albite_._. & 29.34 \\
\hline $\mathrm{FeO}$ & 2.26 & Anorthite_. & 12. 79 \\
\hline 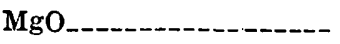 & 1. 06 & Diopside__._._. & 1. 33 \\
\hline - & 3.05 & Hypersthene & 2.60 \\
\hline $\mathrm{Na}_{2} \mathrm{O}_{-}$ & 3.47 & Maguetite & 3. 71 \\
\hline $\mathrm{K}_{2} \mathrm{O}_{2}$ & 4. 53 & Ilmenite & 1.98 \\
\hline $\mathrm{H}_{2} \mathrm{O}-$ & .01 & Apatite & .34 \\
\hline $\mathrm{H}_{3} \mathrm{O}+\ldots$ & .67 & & \\
\hline $\mathrm{TiO}_{2}$ & 1. 00 & & \\
\hline$P_{2} \mathrm{O}_{\mathrm{r}}$ & .19 & & \\
\hline $\mathrm{MnO}_{-}$ & .09 & & \\
\hline & 99.94 & & \\
\hline
\end{tabular}

Class II, order 4, rang 2, subrang 3.

Most of the plagioclase has the average composition of andesine, and the crystals are usually zoned. the outer rim being rarely more sodic than oligoclase. Many of the crystals, however, contain a core of labradorite, sharply set off from the andesine margin, and the shape of the core is such as to indicate intense corrosion of the labradorite grain by the magma in which the crystal was floating. These labradorite cores are made conspicuous by the presence in them of tiny black microlites. In some grains these are rod-shaped and definitely arranged; in others they are spherical and are not opaque, although their minute size and high refractive index make them appear opaque except when seen with high magnification. The identification of the rock that proved to be intensely endomorphosed quartz monzonite was made certain partly by the presence in it of plagioclase 
crystals containing corroded cores of labradorite in which these microlites occur.

The labradorite cores of the plagioclase crystals, the augite cores of the hornblende grains, and the abundant augite and rare olivine in the border facies of the quartz monzonite indicate that the rock began to crystallize as a gabbro, forming augite, labradorite, and olivine. A rapid progressive acidification of the melt occurred, and the early formed minerals, no longer in equilibrium with the melt, were either totally dissolved or partly corroded and made over into new minerals that were in equilibrium under the new conditions. This change is believed to have taken place partly because cooling of the melt made the more basic minerals, which are normally the first to crystallize in a hot melt, unstable, and partly because an acidification actually took place by the addition of volatile emanations from below.

Another striking feature of the quartz monzonite is the presence in it of minerals which, though mainly of pyrogenetic origin, had continued to grow by additions from these emanations after the rock became solid. Hornblende and especially biotite and hypersthene show convincing evidence of having thus grown by replacement of other minerals, but more conspicuous than these is the potash feldspar, which replaced plagioclase in an irregular manner and formed graphic intergrowths by replacement in quartz. In the endomorphosed facies this process was carried so far that the quartz was almost entirely eliminated.

Endomorphosed quartz monzonite. - At several places near the contact of the granitoid facies of the quartz monzonite there is the medium to fine-grained dark rock which in the field appears to grade into the monzonite and is believed to be the monzonite endomorphosed. The largest exposure is on the north slope of the 7,106-foot hill. (See pl. 1, 7.) The same rock is found just across the wash valley to the northwest, and a small amount occurs on the south slopes of McCullough Hill.

The hand specimen shows glistening phenocrysts of plagioclase, reaching 2 or 3 millimeters in diameter, in a dark groundmass containing a good deal of biotite. Quartz can be seen in some specimens. Under the microscope the plagioclase phenocrysts, averaging 1 millimeter in length but reaching 3 millimeters, lie in a groundmass composed largely of clear anhedral equidimensional grains of potash feldspar, which has replaced the plagioclase to different degrees. (See pl. 6.) The plagioclase, however, is not replaced by the potash feldspar except where there had been a previous replacement by a glassy andesine. This was not magmatic corrosion, for where the replacement has gone so far that the plagioclase crystals are reduced to small irregular corroded residuals the margin of andesine is invariably found around the edges of the grains and also in the interiors.

Pale-green augite is abundant in small anhedral grains and locally in subspherical crystals from 9.01 to 0.3 millimeter in diameter. The augite occurs throughout the groundmass and accompanies the andesine and the potash feldspar in their penetration of the plagioclase phenocrysts. Larger, irregular grains of hypersthene are found in the moderately metamorphosed facies. A small amount of green hornblende of a late generation occurs in some places. Irregular sievelike biotite grains 1 to 2 millimeters across are common and inclose the other minerals of the groundmass. Biotite is absent, however, from the specimens that show the most intense metamorphism. Quartz is present in some sections, but is absent from the most intensely metamorphosed facies, having been replaced by potash feldspar. In specimens showing partial elimination of the quartz graphic textures showing replacement of the quartz by the potash feldspar are striking. Small grains of magnetite and ilmenite are widespread, and larger irregular grains of these minerals are found inside many of the biotite grains. Finely divided titanite is abundant locally, and many of the ilmenite grains are surrounded by a halo of titanite. Minute crystals of apatite occur by the thousand in most of the sections. Zircon is present in numerous small grains.

The most intense endomorphism resulted in a rock consisting of potash feldspar in anhedral grains, 0.05 millimeter in diameter, in which are some residuals of plagioclase and abundant anhedral grains of green augite and magnetite. Quartz, biotite, and hypersthene are absent, and the apatite is not so abundant as in the less metamorphosed stages.

The black border facies was identified as the metamorphosed quartz monzonite because it contains plagioclase crystals of the same type attacked in the same manner by potash feldspar, with corroded labradorite cores in which occur similar black microlites. The presence of hypersthene in the two rocks corroborates the other evidence, inasmuch as that mineral is not found in any of the other metamorphosed rocks.

Porphyritic facies.-The porphyritic facies described above have phenocrysts of labradorite feldspar (without black microlites) and a groundmass of sodic plagioclase and interstitial quartz and microcline, and they contain also brownish-green hornblende and brown biotite, both as small phenocrysts and in the groundmass. Pyroxene occurs in a few of the hornblende grains as cores, and some pseudomorphs probably were pyroxene. Biotite is less abundant in the narrow dikes of this rock than in the larger masses. The orthoclasization described above as characteristic of the endomorphosed quartz monzonite has affected 
all specimens of the porphyritic rock studied, and graphic structures formed by replacement are abundant. The augite and the hypersthene formed during the endomorphism of the granitoid facies were not seen.

That type of alteration loosely described as "hydrothermal " has been much more intensely developed in the porphyritic rock than in the granitoid. The primary hornblende has been replaced by an actinolitic variety, and the chlorite and epidote are in places so abundant that the rock has a greenish tint in the hand specimen. A carbonate was formed in some of the more intensely altered zones, and a zeolitelike mineral of very low refractive index and strong birefringence was found in many of the altered plagioclase grains.

\section{ASSOCIATED DIKE ROCKS}

North and east of the northern area of quartz monzonite and irregular intrusions and dikes of darker, finer-grained porphyritic rocks which, though varying in structure and mineral composition, have a general likeness among themselves and to the monzonites.

The large intrusion at the north edge of the area is at its west end (pl. 1, 8) a series of dark-gray rocks. The coarsest variety shows in the hand specimen scattred black patches as much as 4 millimeters in diameter in a gray groundmass. The microscope shows (rystals of plagioclase (andesine-labradorite) 3 or 4 millimeters in length and irregular grains of pyroxene and biotite lying in a granitic groundmass consisting of plagioclase, biotite, hornblencle, pyroxene, magnetite, quartz, and orthoclase. Green hornblende commonly rims the pyroxene and occurs in smaller and larger grains without pyroxene. Accessory titanite, apatite, and zircon are present. The plagioclase shows the same zonal structure, corrosion, and penetration by sodic plagioclase and orthoclase as are seen in the monzonite.

This large northern mass is continued southeastward along the east side of the area as a broad dikelike body. Where this crosses the crest of Blind Mountain (pl. 1, 9) it is a dark-gray rock with indistinct feldspar crystals and scattered black patches of chlorite and epidote. The microscope shows plagioclase (labradorite) 2 millimeters or less in diameter, chlorite and granular products secondary after biotite, and green fibrous hornblende (actinolite), probably derived from pyroxene, in a groundmass of plagioclase crystals, chlorite, epidote, magnetite, apatite, and interstitial quartz.

The large mass that crosses the south slope of Blind Mountain (pl. 1, 10) is a gray rock that shows light feldspars and indistinct black crystals lying in a gray, fine-grained groundmass. The microscope shows plagioclase (andesine-labradorite) as much as 4 millimeters in diameter and rare crystals of colorless pyroxene lying in a groundmass composed of plagioclase, biotite, chlorite, magnetite, green hornblende, and quartz, averaging 0.2 millimeter in size of grain. The groundmass has a granitic structure with a tendency to idiomorphic development of the smaller feldspars.

The smaller bodies yield finer-grained varieties. A specimen taken from a small intrusion on the west flank of Blind Mountain was a dark-gray indistinct porphyritic rock. The microscope shows crystals of plagioclase (andesine) 2 millimeters in maximum diameter and of some darker constituents, now wholly altered to an aggregate of calcite, chlorite, green hornblende, and magnetite lying in a very fine-grained granular feldspathic groundmass which contains abundant scattered grains of the other minerals listed.

\section{GRANITE PORPHYRY DIKES}

Granite porphyry dikes occur near Pioche and in other parts of the district. The larger dikes are shown on the general geologic map (pl. 1) and those near Pioche in Plate 7. The best known is the Yuba dike, which can be traced almost continuously in the quartzite south of Pioche from the Alps mine, at the edge of the wash, in a direction $\mathrm{N} .70^{\circ} \mathrm{W}$. to a point just east of the Combined Metals mine. It is found in the shale just west of its contact with the quartzite but does not extend into the limestone. It ranges in width from 10 to 100 feet, averages about 75 feet, and dips steeply south. A series of smaller dikes with a northeasterly trend cut the east face of the limestone hill just west of the old Susan Duster mine. Several small outcrops on the west slope of the hill seem to mark a continuation of this group of dikes. The failure of the dikes to continue in unbroken outcrop is clearly due to intermittent occurrence at the surface rather than to concealment beneath the débris.

Pack ${ }^{25}$ reports that a quartz porphyry dike occurs on the west side of the Ely Range, 2 miles west of Pioche, at the Abe Lincoln mine, in line with the general course of the Yuba dike. Farther west, due north of Highland, a 20-foot porphyry dike crosses the low eastern spur of Arizona peak. Still farther west a similar dike crosses the south end of the Bristol Range and can be traced, with offsets, to a point west of the divide at Stampede Gap. These last-mentioned occurrences are in a general way in alinement with the Yuba dike and suggest a transverse zone of fissuring along which either intrusion took place at widely spaced intervals or for considerable distances the intrusive mass failed to reach the surface.

The petrographic character of the granite porphyry dikes is fairly uniform. A specimen taken at the east end of Arizona Peak is a medium-grained gray rock that weathers brown and shows abundant crystals of

${ }^{25}$ Pack, F. J., Geology of Pioche, Nev., and vicinity : School of Mines Quart., vol. 27, p. 299, 1926. 
GEOLOGY AND ORE DEPOSITS OF THE PIOCHE DISTRICT, NEVADA

quartz and feldspar. The microscope shows rounded quartz crystals as large as 3 millimeters (the hand specimen has one 7 millimeters across) and feldspar, probably originally orthoclase but now completely altered, chiefly to mica. One feldspar grain is plagioclase. The small amount of dark minerals was originally chiefly if not wholly biotite but is now completely altered to aggregates of chlorite, iron oxide, and undetermined granular products. The ground. mass is a fine-grained aggregate of quartz, orthoclase, and mica.

The granite porphyry dikes are believed to have had no active part in forming the ore deposits. Most of the mines of the district are in areas where no dikes are known to occur. The Yuba dike cuts the quartzites almost vertically, and as a structural element it determined the course of some of the ore-bearing solutions as they ascended from great depth; it did not itself furnish those solutions.

\section{MINOR OCCURRENOES OF GRANITIC ROCK}

At several points small exposures of granitic rocks or scattered granitic boulders where there are no outcrops suggest concealed masses. The most noteworthy occur just southwest of the road at Bristol Pass, at the junction of a small east-west spur with the low north-south ledge, where there are scattered boulders but no outcrop; in a pit just north of the Ely mine, where highly sericitized granite is exposed; and 2 miles north of Bristol Pass, on the east side of Fairview Wash, in the west base of the Devonian ridge.

\section{LAMPROPHYRE}

A few narrow dikes of lamprophyre have been found, chiefly in Lyndon Gulch, where they cut the limestones. They consist of blackish, even-grained microgranular rocks made up largely of augite and biotite. The augite occurs in two generations, the first generation being represented by sparse microphenocrysts. The biotite shows the deep-tinted borders so common to the biotite in lamprophyres. The rocks are much altered, and carbonate is the principal product. There is some evidence to suggest that these rocks are minettes, but it appears best to call them biotitic augite lamprophyres.

\section{DIABASE OF THE ELY RANGE}

Two dikes of diabase cut the quartzite of the west base of the Ely Range 3 miles southeast of Pioche. The northern dike runs in a southeasterly direction for a mile and then disappears beneath the wash. It has a maximum width of nearly 700 feet and dips steeply northeast. The other dike is parallel but smaller.

The rock is dark greenish gray and fine grained and weathers rusty brown. The microscope shows irregular crystals of plagioclase, augite, and magnetite lying in a groundmass of the same minerals, with some quartz. The rock is much altered and has large amounts of secondary epidote, chlorite, calcite, and granular material (leucoxene?).

A second specimen is dark gray and finer grained and is spotted with amygdules 1 or 2 millimeters in diameter. The microscope shows plagioclase (andesine) and augite measuring 0.5 millimeter or less scattered through a groundmass consisting of plagioclase laths as much as 0.2 millimeter in diameter lying in a groundmass of augite, magnetite in skeleton crystals, and abundant alteration products, especially chlorite, epidote, and leucoxene. The round amygdules are composed chiefly of chlorite, but one shows calcite and quartz at the center.

The quartzite immediately adjacent to the dike is slightly altered. The original rock consisted mainly of quartz grains, with a few grains of plagioclase and microcline. A very little biotite, which is mostly altered to chlorite and iron oxide and which may have been introduced at the time of intrusion of the dike, lies between the quartz grains and in the cracks in the feldspar. There is nothing in the character of the adjacent rocks to indicate that these dikes may be ore bearers.

\section{CONTACT METAMORPHISM}

By Joseph L. GiLlsoN

The endomorphism of the quartz monzonite previously described may be considered a final stage of the igneous intrusion. Contemporaneous changes were taking place in the surrounding rocks, both sediments and lavas, which are here treated separately under the general head' of contact metamorphism. This metamorphism that accompanied the Blind Mountain intrusions is only a part of the metamorphism in the district, although all is probably connected with a deep-seated intrusive body of which that small mass is simply a cupola. There is an area of intensely contact-metamorphosed rocks farther south near Manhattan Gap, extending eastward into the valley north of the Mendha mine and westward nearly to the base of the Highland Range. At least two other areas of metamorphism are known, but in these the process was carried only so far as to marmarize the limestones. One of these areas is on the west side of the Bristol Range, a mile north of the Bristol mine; the other is on the north side of the Ely Range at and a little west of the Ely Valley mine. Besides these local areas of severe contact metamorphism the Cambrian limestone at certain horizons has been marmarized to a white rock of velvetlike appearance consisting entirely of calcite, although much of the original rock was a dolomite. These velvet beds are widespread, and their whiteness makes them conspicuous even at a distance. 
BLIND MOUNTAIN AREA

\section{SIZE OF AREA AND ROCKS AFFECTED}

The rocks around the intrusive mass of quartz monzonite are intensely metamorphosed through a zone half a mile in width on the south, east, and north. The west side, being for the most part covered by wash, does not well show the altered zone. The rocks in the zone of metamorphism include the Lyndon and Highland Peal limestones and Pioche shale of the Cambrian, and, in the down-faulted overthrust block, Devonian limestones and Tertiary (?) lavas. The basal formation of the Cambrian, the Prospect Mountain quartzite, although exposed near the intrusion, seems to show no effect of metamorphism, nor do small isolated blocks of the Devonian quartzite in the overthrust block.

The most intense metamorphism is confined to a narrow belt near the intrusion; the more distant metamorphism is merely a marmarization of the limestones and slight changes in the shales.

\section{IIMESTONES}

Owing to the lithologic similarity of the Lyndon and Highland Peak limestones and the limestones interbedded in the Pioche shale the metamorphism of the limestones will be described under a single beading.

The marmarization of the limestones requires little comment. Any original dolomite in the limestone was removed and calcite deposited in its place. Locally veins of dolomite were formed at a late stage in the metamorphism. A striking feature of the marble beds is that much of the carbonate is optically biaxial. ${ }^{26}$ Some beds of the marble contain disseminated silicates in amounts too small to be noticed on megascopic examination. Such a bed from limestone in the Pioche shale south of McCullough Hill yielded, on solution in acid, a considerable residue, mostly grossularite with a little diopside. A bed of Highland Peak limestone east of $\mathrm{McCullough} \mathrm{Hill}$ contained disseminated grains of a pale mica.

Garnet is common in the limestone adjacent to the quartz monzonite, though it is not present in large quantities. It occurs in small masses along the east side of the quartz monzonite mass north from McCullough Hill. A small mass was found on the ridge east of the 7,106-foot hill, where a small prospect hole has been opened. The rock is a vuggy mass of small honey-yellow garnets, quartz crystals, a green amphibole, and subordinate epidote, serpentine, chlorite, and magnetite. The garnet is distinctly zoned, and many of the zones are birefracting.

so Gillson, J. L., Blaxlal calcite: Am. Mineralogist, vol. 12, pp. 357360, 1827.
A garnet rock was found at a small copper prospect east of the north end of the igneous area. (See pl. 1, 11.) The garnets are yellow and zoned and have an index of refraction of 1.87 . The rock also contains vesuvianite, a little diopside, quartz, green serpentine, and a fibrous mineral resembling the szaibelyite found at another prospect and described below.

Float in the vicinity of Blind Mountain Spring contains grossularite, pyroxene, green vesuvianite, wollastonite, and a little epidote.

Olivine (forsterite), largely altered to serpentine, is disseminated as minute specks in a coarse marble east of McCullough Hill.

A bed of banded limestone was found near the south contact of the igneous rock on McCullough Hill. It contains quartz, potash feldspar and plagioclase, zircon, titanite, and apatite in the shaly partings and tremolite, diopside, epidote, and garnet in the limestone bands. At a point east of the 7,106-foot hill a banded rock from the Highland Peak limestone consists of dense green limestone layers 1 centimeter thick separated by white shale partings from 1 millimeter to 1 centimeter thick. Quartz, orthoclase, and a mica are the principal constituents of the shaly partings; the green bands are made up of diopside, probably vesuvianite, and calcite. A similar bed on the south slope of Blind Mountain contains quartz and finely divided orthoclase in the shaly partings, and epidote is the principal mineral in the originally calcareous bands.

\section{PIOCHE SHALE}

A gradual transition from unmetamorphosed to intensely metamorphosed shale beds is found by walking north toward McCullough Hill from the road leading down the west side of Stampede Gap. At the road the rock shows no visible metamorphism, but as the ridge north of the road is climbed the shale is found to be harder, to break into larger fragments, and to show small dark-green spots and larger "eyes" of a dark-brown color. Nearer the intrusion the rock is a fine-grained, nearly black flintlike rock that breaks with a conchoidal fracture.

A study of these progressive changes was made with the microscope. The rock at the road, though apparently unmetamorphosed, contains disseminated magnetite, a mineral absent from the unmetamorphosed rock. In the moderately changed rock disseminated minute grains of potash feldspar and biotite are abundant. These have formed at the expense of the quartz and sericite, probably with some addition of material. In some slides the change of the sericite into feldspar is clearly seen in grains in which the process has not been carried to completion. The biotite has a deep-brown color and a refractive index for $\beta$ of 1.680. Scattered grains of tourmaline 
in the moderately metamorphosed rocks might be considered of detrital origin, although the mineral is absent from the slides of unmetamorphosed rock examined. That the tourmaline was formed in the shale by metamorphism, at least in many places, is proved by its abundance in some rocks near the igneous contact. In a bed near Blind Mountain Spring tourmaline makes up 5 per cent of the rock, and some of the grains are three times as large as the original quartz grains.

Muscovite of a second generation is found in the more metamorphosed beds. Sheaf-like aggregates, associated with biotite, form the "spots" or "eyes" sten in the field. Some of these mica aggregates contain a corona of a very finely divided mineral, of high relief. Its identity was not established.

The severely metamorphosed beds of the Pioche shale exhibit at least two mineralogic varieties. The more common variety is made up of cordierite, labradorite, andalusite, and biotite; the other variety contains none of these minerals and consists of corundum and tourmaline. Both contain quartz, potash feldspar, apatite, and magnetite. Both varieties are finely crystalline and made up of interlocking aggregates of anhedral grains. No sequence of mineral formation could be established, owing to the small size and intimate interlocking of the grains.

As an example of the rock produced by the more common type of metamorphism, a bed from the south slope of McCullough Hill may be described. Under the microscope it is seen to consist of poikilitic patches of cordierite, 0.3 to 0.5 millimeter in diameter, holding countless small round blebs, partly of potash feldspar and partly of quartz. Common also are blebs of magnetite 0.015 millimeter in diameter. The biotite contains scattered larger grains of magnetite and also scattered grains of a plagioclase near labradorite. In this cordierite-quartz-feldspar groundmass are metacrysts, many of which are themselves poikilitic, of biotite, muscovite, and andalusite. The andalusite occurs as square prisms, with irregular terminations. Many grains show a beautiful rose pleochroism. Apatite occurs in small quantity; zircon is still less abundant.

A bed on the spur west of Blind Mountain Spring near the contact with the quartz monzonite differs in containing very abundant sillimanite and rare andalusite. Another bed, near by, consists of labradorite, quartz, and cordierite, with potash feldspar not abundant. Rutile needles are widely disseminated. Some grains of this mineral are mere hairs; others are 0.003 millimeter in diameter and 0.1 millimeter long. Zircon is more abundant than in the other beds.

A bed of the corundum-tourmaline hornfels was also found on the west spur of Blind Mountain. It consists of metacrysts of corundum and tourmaline set in a groundmass of quartz, potash feldspar, and white mica. The corundum grains are anhedral, have a blue pleochroism, average 0.3 millimeter in diameter, and are surrounded by a mica-free halo of potash feldspar. Tourmaline makes up 5 per cent of the rock. The grains are predominantly prismatic; many are as long as 0.15 millimeter, and a few even longer. White mica forms 50 per cent of the rock and occurs as a mass of minute foils in random orientation. Tiny grains of magnetite or ilmenite are so abundant that 10 to 15 per cent of the rock is composed of them. A.patite is not rare. A brown serpentine or chloritic mineral, of very weak birefringence, forms disseminated large grains. Patches of minute grains of titanite are disseminated irregularly. Quartz is not abundant.

\section{LAVAS AND TUFFS}

Metamorphosed lavas and tuffs are found in the northern part of the Blind Mountain area. Their distribution is shown on Plate 1 . They range from small masses 50 feet across to the large area, over 1,000 feet long, which caps Blind Mountain; but whether large or small, it is singularly difficult in the field to make out their structural relations. It is not certain on structural evidence alone whether they are intrusive or extrusive. At many points their intimate association with rocks that are apparently dikes suggest that they are intrusive; but their resemblance to lavas and tuffs under the microscope and the common presence of flow structure favor the inference that they are extrusive. They are limited to the downfaulted Devonian block at Blind Mountain and are believed to be infaulted parts of the badly broken overthrust block.

Many of the metamorphosed volcanic rocks have a cream or a brownish brick color on weathered surfaces and a light-greenish color on the fresh fracture. Others are very dark brown to nearly black. On close inspection small feldspar phenocrysts can be recognized in most of them.

The old volcanic breccias are recognized most easily. They contain angular to rounded fragments of dense dark chocolate-brown rock in a mottled greenish groundmass. Closer examination shows abundant small rounded or irregular masses, green or black in color, bordered with white, formed by aggregates of secondary minerals. In places the breccias have small open cavities containing garnet, epidote, magnetite, and amphibole.

In general the process of metamorphism involved the elimination of all the original ferromagnesian minerals and the formation of a new generation of potash feldspar and new ferromagnesian silicates, the latter commonly very finely divided. To illustrate the process a description will be given of the metamorphism 
of some lavas-andesite and basalt-and then of some tuffs and breccias.

East of the 7,106-foot hill (pl. 7, 12) a considerable area is covered with fragments of a nearly black rock, weathering light brown and containing scattered plagioclase crystals reaching 1.5 millimeters in length. When seen under the microscope only the old plagioclase phenocrysts, quartz, apatite, and pseudomorphs of original ferromagnesian minerals indicate the original character of the rock. An intense orthoclasization of the groundmass and an attack on the phenocrysts have nearly eliminated the original minerals. In the orthoclase clouds of minute grains of biotite, pyroxene, and magnetite, with smaller quantities of other minerals, are present, and these have given the dark color to the rock. The plagioclase phenocrysts are zoned and contain labradorite cores. The labradorite has a dark tint due to the presence of inclusions which are almost submicroscopic. All the phenocrysts show to a greater or less degree an attack by the orthoclase. In the first stages the orthoclase has entered the plagioclase as narrow irregular veins, in many places following cleavage cracks. With further attack large portions of the original plagioclase are completely replaced by orthoclase. In the orthoclase replacing the old plagioclase grains the quantity of the finely disseminated biotite, pyroxene, and magnetite is small, except near the edge. In the groundmass these minerals are so generally distributed as to appear under moderate magnification as a cloud of minute specks. Accumulations of nearly solid masses of the minute dark silicates and magnetite represent imperfect pseudomorphs of old ferromagnesian minerals. Many have the form of old augite crystals. Larger grains of magnetite are fairly abundant. Most of these have the form of deuteric magnetite found in igneous rocks and are presumably of a late period of formation. A finely divided deep-brown mineral associated in subordinate amounts with the biotite and pyroxene is probably rutile. In specimens of this rock showing the most intense alteration the plagioclase phenocrysts have been so thoroughly replaced by orthoclase that they almost escape recognition. They are most conspicuous between crossed nicols, where the finely divided nature of the orthoclase makes the remnants of large crystals of plagioclase stand out because of the higher interference colors. Aggregates of pyroxene grains are numerous. The individual grains average about 0.003 millimeter in diameter; the aggregates are as large as 0.25 millimeter. In general the shape of the aggregates is very irregular. Many contain cores of magnetite grains. Biotite also forms aggregates, many of which contain a single large grain of magnetite in or near the center. In such aggregates the projecting fingers of the mag- netite indicate that it was formed later than the biotite. Some grains of the opaque mineral are probably ilmenite, as many are surrounded by a halo of minute titanite grains.

Another lava from the large area near the summit of Blind Mountain shows similar alteration, although, in addition to the finely divided augite, an amphibole of actinolitic habit was formed. Epidote and titanite are also generally distributed, and a few small grains of allanite were found. The rock contains numerous elliptical spots from 1 to 5 millimeters in greatest. diameter. These have a black core and a white rim. The black core in some is an augite but in others is an amphibole $(\beta=1.690)$, with weak birefringence and distinct dispersion $(\rho>v)$ and optically negative. With the amphibole is a brown isotropic garnet, having an index of about 1.87. The white rim is andesine, which shows partial replacement by orthoclase. These spots are peculiar in that they seem to have no relation to the general mineralization of the rock, the individual grain size of which is very much smaller. The spots are so large that only rarely is one seen in thin section, and there it is as a rule sharply set off from the rest of the rock.

The apatite is so abundant in many of the metamorphosed lavas as to suggest that some is a new generation, representing an introduction of material. In a few slides very long needles crosscutting the boundaries of several grains were seen, and it is reasonably certain that this apatite at least is a new generation.

In some of the lavas in which considerable quartz occurred as one of the pyrogenetic minerals graphic textures made by replacement of the introduced potash feldspar with the quartz are numerous.

The metamorphosed volcanic breccias represent a similar process of metamorphism but offer wider variations, inasmuch as the original rock was not uniform. The tuffaceous nature of the groundmass is in general readily apparent under the microscope. The irregular streaks and angular fragments of original glass are preserved as pseudomorphs, although they are now rnade up almost entirely of orthoclase containing abundant grains of dark-colored silicates averaging 0.001 millimeter in diameter. Pseudomorphs of twisted and bent biotite, common to tuffs, and angular fragments of foreign rocks testify to the original character of the rock. Spherical aggregates and druses of secondary minerals are widely distributed in these rocks. Original plagioclase phenocrysts are generally more or less replaced by orthoclase. Several grains of original ferromagnesian minerals remain, but for the most part these minerals have been entirely eliminated. One section of an old hornblende was found, rather generally altered to a carbonate and surrounded by 
a rim of finely divided pyroxene. In another specimen a large augite had begun to break down into small grains of the same mineral. Aggregates of small augite and amphibole grains are widely distributed in these metamorphosed rocks, and many seem to be pseudomorphs having a general shape similar to an original augite or hornblende grain. Many such aggregates contain numerous small grains of magnetite. In another rock a number of the aggregates of augite grains contained cores of small grains of the same mineral, surrounded by larger grains, and all surrounded by a narrow rim of a mineral of higher relief, probably titanite.

The rock fragments in the volcanic breccias show a great variety of mineralogic features. Most of these are similar to the contact-metamorphosed lavas and consist of a groundmass of finely divided potash feldspar, large plagioclase grains severely attacked by the solutions which had formed the potash feldspar, and disseminated ferromagnesian grains of small size, among which epidote and titanite are more abundant than in the lavas themselves. Biotite, which is commonly disseminated widely in the beds of lava, is absent from most of the metamorphosed volcanic breccias.

Green or black spots with a white core are abundant in the volcanic breccias. In a rock from the top of Blind Mountain the green cores consist of aggregates of augite or of an actinolitic hornblende, the $\beta$ index of refraction of which is 1.650. The white rim to the spots in this rock is made up of calcite, many of the grains of which are biaxial.

Garnet is irregularly distributed in the volcanic breccias. Many grains 0.5 centimeter across are seen with the naked eye, and under the microscope scattered crystals were found in many sections. It seems to have been one of the last minerals to form. Where tested, this garnet has a very high index of refraction (near 1.90) and a reddish-brown color.

Druses partly filled with pretty crystals are also widely distributed in the metamorphosed breccias. In one rock these have a lining of minute pyroxene grains, and the druse is partly filled with a nearly isotropic chlorite, an acicular green amphibole, and some magnetite. In another a druse was found inside of a lens, 2 centimeters long, formed of massive acicular grains of an amphibole. The margin of the lens is lined with octahedrons of magnetite on which are perched acicular needles of the same amphibole.

\section{MIXED ROCKS}

On the north slope of the 7,106-foot hill (pl. 1, 13) an inquisitive prospector has opened a cut in a 5-foot veinlike mass of green diopside and spinel. Twenty feet from this trench is the true quartz monzonite, and this rock occurs in place on the right side of the - vein and grades sharply into it. Between the vein and the main mass of the quartz monzonite no outcrops are found, but the surface is littered with float of unusual rock types. The diopside-spinel rock consists of only these two minerals. The pyroxene has a $\beta$ index of 1.692 , and the subhedral crystals, which reach 1 centimeter in diameter, have a grass-green color. The spinel is black, though deep green in color by transmitted light, has a refractive index of 1.740 , and reacts chemically for $\mathrm{Mg}, \mathrm{Al}$, and very little for $\mathrm{Fe}$. Most of the grains have curved surfaces, but they do not appear to have been corroded. A few are octahedrons. The quartz monzonite grades sharply into a nearly white, dense rock consisting of a white pyroxene, the $\beta$ index of which is 1.690 , and an isotropic garnet (grossularite), index 1.75. This rock also grades into another greenish rock with a reddish tint, containing vesuvianite and locally a very considerable amount of wollastonite. In several specimens with the colorless pyroxene is another augite, green in section, that has a $\beta$ index of refraction of 1.705. Calcite occurs more or less abundantly with these silicates. Another variety, not found in place, is an aggregate of pyroxene, vesuvianite, calcite, and a greenish mica, colorless in section. The mica occurs as pseudohexagonal tabular crystals reaching 1 centimeter in diameter. The indices of refraction are $\alpha=1.555, \beta=\gamma=1.588$. The mica is intergrown with or altered to another micaceous mineral, colorless in section, the indices of which are $\alpha=1.530, \beta=\gamma=1.555$. The diopside-spinel rock and the vesuvianite-wollastonite-calcite rock seem to have been the result of the metamorphism of limestone masses in the quartz monzonite. The other varieties may have been derived from the quartz monzonite itself by solutions which had soaked through the limestone.

Another unusual aggregate of minerals was found at a copper prospect on the west base of Blind Mountain. (See pl. 1, 14.) Here borate minerals had formed in considerable quantity. In a zone 20 feet across, bounded by white marble, a peculiar subspherically banded black and white rock occurs, followed successively by a green rock of diopside and spinel similar to that at the other locality, endomorphosed quartz monzonite, and normal quartz monzonite. The peculiarly banded black and white rock contains the borate minerals ludwigite, szaibelyite, and fluoborite, associated with magnetite, serpentine, dolomite, and hydromagnesite. The occurrence has already been described. ${ }^{27}$ At the time this description was published the mineral now considered to be fluoborite was not identified, as the grains were too small to be separated

${ }^{27}$ Gillson, J. L., and Shannon, E. V., Szaibelyite from the Ploche, Nev., district: Am. Mineralogist, vol. 10, pp. 137-139, 1925. 
for analysis and the optical properties did not check with those of any other known mineral. More recently Geijer ${ }^{28}$ found a similar mineral association in a specimen from the Norberg district in Sweden and identified a new mineral which he called fluoborite, having the composition $3 \mathrm{MgO} \cdot \mathrm{B}_{2} \mathrm{O}_{3} \cdot 3 \mathrm{Mg}(\mathrm{F}, \mathrm{OH})_{2}$. The optical properties of this mineral agreed with those previously reported by Gillson and Shannon, and Doctor Geijer ${ }^{20}$ has suggested that this mineral in the Pioche occurrence is the same. Small amounts of bornite and chalcopyrite, now partly oxidized, had attracted the prospector, whose work had opened up a deposit that might easily have passed unnoticed.

\section{MANHATTAN GAP AREA}

An area centering at Manhattan Gap, half a mile north and south by a third of a mile east and west, is underlain by a brown-weathering rock consisting chiefly of garnet. The garnetized area is surrounded by a rather wide zone of marmarized limestone, and the near-by Pioche shale is also somewhat changed. The metamorphism did not extend as far north as Stampede Gap, so that nearly 2 miles of unmetamorphosed rock separates this area from the intrusive rocks of Blind Mountain. No igneous rock is exposed in the Manhattan Gap area other than the west end of the porphyry dike mentioned on page 35 , which is not believed to be the cause of the metamorphism.

At the north end of the metamorphic area the almost unaltered blue limestone is cut by veins along which iron-bearing solutions of surface origin have stained the rock. Nearer the center of the zone the rock is a velvetlike marble that contrasts sharply with the unmetamorphosed blue limestone with which it is locally in contact. The marble is cut by many pink, iron-stained calcite veinlets, and both the marble and the limestone are cut by white veins of sugary dolomite.

The more intensely marmarized limestone is coarsely granular and contains minute disseminated grains of garnet, quartz, a little colorless mica, a chlorite, magretite, and pyrite. The magnetite and pyrite have been altered to hematite at the surface, and where such a rock has weathered and the carbonate has been leached a porous, cellular mass of iron oxide has been formed. It was by such a process, accompanied by some redistribution of the iron, that the surficial bodies of iron ore formerly mined were produced.

The garnet rock is dark brown and consists essentially of coarsely crystalline subhedral brown garnets,

ss Geljer, Per, Some mineral associations from the Norberg district: Sveriges geol. Unđersökning, ser. C, No. 343, pp. 26-27, 1927.

co Personal communication. $89276-32-4$ with disseminated amphibole, quartz, augite, epidote, calcite, magnetite, and pyrite. The composition of the garnet varies from place to place. At one place it is light brown by transmitted light, weakly birefracting, and distinctly zoned and has an index of refraction of about 1.90. In another place it is yellow-green in thin section, anisotropic, and zoned but has an index of only 1.83. At still another place two varieties of garnet were found in the same hand specimen, one having indices of 1.787 and 1.792 , the other an index of 1.815 .

The augite in the garnet rock has a greenish color in section and a $\beta$ index of 1.705 .

The amphibole had several stages of growth. The first one to form had the following properties:

$$
\begin{aligned}
& \gamma=1.679 \quad 2 \mathrm{~V} \text { about } 60^{\circ} \quad \mathrm{X}=\text { yellow-green } \\
& \beta=1.672 \quad \mathrm{Z} \wedge c \quad 25^{\circ} \quad \mathrm{X}=\text { green } \\
& a=1.655 \quad \mathrm{Z}=\text { blue }
\end{aligned}
$$

This amphibole is surrounded by a later one having paler pleochroic tints and lower indices of refraction, $\beta$ being about 1.653. Both varieties have in part been replaced by a yellowish mineral of fibrous habit, lower indices, parallel extinction, and a strong birefringence. It is probably a mineral similar to bowlingite. This in turn is locally replaced by a carbonate of fibrous habit.

The succession of mineral formation appears to have been garnet, pyroxene, epidote, hornblende, calcite, magnetite, and sulphides. Quartz appears to have formed through a long period of time, as scattered through this metamorphic zone are large veins cf massive quartz and jasper rock. These veins were fcrmed later than the silicate zones in the limestone, and much of the jasper was probably formed recently by surface solutions. On the other hand, some of the quartz in the silicified limestones appears to have been earlier even than the garnet.

The Pioche shale occurs within this area, but at no place was it strongly metamorphosed. Except that the beds are more resistant to erosion than the unmetamorphosed beds, the rock shows little megascopic evidence of metamorphism. Under the microscope the grain size is seen to be about the same as in the unmetamorphosed shale, but instead of consisting entirely of quartz and sericite, the rock contains 40 per cent of biotite and in addition finely granular potash feldspar and quartz, scattered long needles of tourmaline, and disseminated minute grains of magnetite.

The Chisholm shale is also slightly metamorphosed in this area. From 25 to 30 per cent of the rock is biotite, and a like amount of muscovite is present; finely divided potash feldspar and quartz make up most of the rest of the rock, but there are scattered grains of tourmaline and of magnetite and ilmenite. 


\section{CONCLUSIONS}

The study of the contact zones described above has led to the conclusion that the main part of the metamorphism followed the solidification of the cupola of igneous rock now exposed. The cupola itself has been changed by solutions that passed up through it during and after consolidation. These caused the greatest recrystallization along the margins of the igneous rock or in its roof.

It is concluded, therefore, that the metamorphism of the sediments and lavas surrounding the igneous rock was not caused by the act of intrusion of this relatively small mass, nor by solutions given off. by it at the time of intrusion, but rather by solutions given off from some igneous body deeper down and still concealed. Similarities in the formation of new minerals in the exomorphic and endomorphic zones, the most significant of which are the occurrence of orthoclasization in both zones and the widespread formation of micas, pyroxene, magnetite, and apatite make it reasonable to connect the exomorphism with the endomorphism and to refer both to a deep-seated body of igneous rock.

It would seem that in the Pioche district the evidence is very convincing that the volatile emanations given off after the magmatic intrusion have been of the greatest importance in determining the final character of the exposed intrusive itself, and that they account also for the contact metamorphism which is so striking.

The possible connection between the intrusive rocks and the mineralization of the region requires comment. The Yuba dike has long been considered the cause of the mineralization of the veins in the quartzite at Pioche. The field facts, however, do not bear out this idea. Certain dikes have caused a little metamorphism in the rocks adjacent to them, especially the limestones, but this metamorphism has consisted chiefly in coarsening the grain of the limestones. The granitic mass at Blind Mountain has produced extensive metamorphism in the adjoining shales, limestones, and igneous rocks. At a few points small amounts of metallic sulphides occur at the contact, but no èconomically important ore bodies were formed in this way. At Manhattan Gap, south of the Blind Mountain area, the limestone is completely replaced by garnet, pyroxene, and iron oxides. No igneous rock shows at this locality, but it would not improbably be found in depth. The iron ore here has been mined. Yet, in general, the statement is true that the presence of igneous rocks is not a specially favorable indication of ore deposits of value. Broadly considered, the ores were probably formed by solutions that came from buried igneous rocks, but these are not to be con- nected with the igneous rocks now exposed at the surface.

\section{STRUCTURE}

The rocks of the Pioche district are tilted and gently folded and at a few places show single sharp folds. They are everywhere faulted, so that the structural problems of the district center in the faulting. Many faults, including most of the major faults, are shown on Plate 1, and the structure of the region is shown in Plate 2. The much greater number of faults that are mapped along outcrops of beds at well-defined horizons, such as the Cambrian shales, the beds at the Highland Peak-Mendha contact, and the quartzite of the Ely Springs Range suggests that many of the faults in areas of thick monotonous formations; like the Highland Peak, Mendha, and Silverhorn, have not been detected. The faulting occurred at different times and included both normal and thrust faulting. The lack of a sufficiently complete sedimentary series renders it difficult to interpret the fault history. The series includes the following members:

1. The Paleozoic sediments, Cambrian to Pennsylvanian, which can be taken as a unit. It probably contains unconformities, though none were certainly recognized; if present, they are disconformities, and the deposition of the Paleozoic formations was not interrupted by folding or faulting. All the faults of the district are post-Pennsylvanian.

2. The Tertiary (?) lavas and associated tuffs, which contain disconformities and probably were a long time in accumulation. Faulting probably preceded and certainly followed the eruption of the lavas, but most of the faults are later than the lavas.

3. The Pliocene (?) sedimentary tuffs. All the faulting of the district was completed before their deposition.

\section{THRUST FAULTING}

Thrust faulting was not the earliest faulting in the Pioche district, but for the sake of clearness of presentation it is considered before the normal faulting, as its recognition makes possible the assignment of the normal faulting to more than one period.

Thrust faulting is best shown at the north end of the Bristol Range and on the east side of the West Range. (See pl. 1.) In the main range the line that separates the dark massive rock of the overthrust block from the well-bedded lighter rocks below is well seen from the road approaching Bristol Pass from the east. The dip of the fault plane here is $8^{\circ}-9^{\circ} \mathrm{W}$. West of the divide streams have cut through the overthrust block into the underlying rock, and south of the Bristol mine the overthrust exists as cappings of c f few isolated hills. The overthrust rock here is Devonian; the underlying rocks are Cambrian and 
Ordovician. The Devonian of the overthrust block is the dark-colored dolomite and capping quartzite of the Silverhorn formation, almost completely unfossiliferous but easily recognizable by its lithologic character. It is greatly brecciated, so that the bedding rarely shows, and no structure can be made out within the block. This is true also where the quartzite masses occur; even with their aid it is impossible to determine the structure. The underlying limestones arc noticeably brecciated. The thorough brecciation of the overthrust block suggests that it was not under: a heav $y^{\circ}$ load at the time of faulting.

The overthrust in the West Range shows the same brecciated Devonian (Silverhorn) dolomites and quartzite that are shown in the Bristol Range: Here, however, the dip of the fault plane is to the east. In the southern two-thirds of its course the overthrust rests on the Devonian, but for over a mile at the north end of the range it rests on the Tertiary (?) lavas and tuffs. A little over a mile south of the north end of the range a lens of Tertiary (?) tuff has been caught between two slabs of the overthrust.

The southern continuation of the overthrust block is found in several areas of badly broken Upper Cambrian (Mendha) limestone which occur west of Stampede Gap, between the Highland and Ely Springs Ranges, and extend south from Simpson Spring for 5 miles. On the east side of these areas the overthrust block is separated from the Cambrian by a low-angle westward-dipping fault. On the west side the block does not come into contact with the other rocks except for about a mile at the south end, where it is in contact with the lavas east of the Ely Springs Range and where its structural relations to the lavas are not clear.

On the east side of the Black Canyon Range, 2 miles north of Black Canyon and just north of the narrow wash-bottomed valley that cuts across this range, Upper Cambrian (Mendha) limestone seems to lie on top of the tuffs, repeating the conditions in the West Range. If so, this is a fragment of the overthrust block. At the extreme west base of the Ely Springs Range, on the point 1 mile N. $30^{\circ} \mathrm{E}$. from bench mark 4754, the structural features strongly suggest but do not definitely prove that the end of the point is an overthrust block, with fault plane dipping west.

The general structural relations of the overthrust are not clear. No exposures of the fault plane were seen, and the overthrust block itself is separated by erosion into several parts and is apparently without roots in the immediate region. In the Bristol Range quadrangle the formation boundaries show that the fault plane dips west in the Bristol Range and east in the West Range. The most probable interpretation of the overthrust between the Highland Range and the Ely Springs Range is that here too the fault plane dips in from each side, though the field evidence for this is not clear along the west side. This synclinal form of the fault plane is due either to downwarping or downfaulting.

It is not certain whether the movement of the overthrust block was toward the east or west. There is no noticeable drag in the underlying rocks. At one or two points there are inconclusive indications in the base of the overthrust block that the movement was toward the west. Longwell, ${ }^{30}$ however, has described thrust faults in the Las Vegas and St. Thomas quadrangles, 75 miles south of Pioche, which occur through a belt 50 miles wide and bear north-northeast, directly toward Pioche, and along which movement was to the east. It is therefore probable that when the intervening area is studied the Pioche thrust faulting will prove to be an extension of that to the south, with a. movement of the overthrust block to the east.

\section{EARLIER NORMAL FAULTING}

The earlier normal faults can be recognized only in the Bristol Range quadrangle, where they occur alongside the thrust faults. In the West Range several approximately east-west faults cut the Devonian limestones of the west side of the range but do not displace the thrust fault. The Ida May fault crosses the north end of the Bristol Range in a northeasterly direction and has itself a large displacement; it meets the thrust fault under the alluvium, but the position of the plane of the thrust fault north and south of the Ida May fault shows little if any displacement.

With these faults, which clearly antedate the thrust faulting, are probably to be associated the series of east-west faults which cut the Bristol Range with upthrow on the north side and which thus have kept the heavy white upper beds of the Highland Peak limestone at the crest of the range, in spite of a general northerly dip. These faults are clearly recognized along the crest, where they cut the heavy white limestone and the Highland Peak-Mendha contact, but they are not traceable across the lower slopes of the range through the monotonous middle and lower beds of the Highland Peak limestone.

Possibly some of the faults in the Silverhorn region belong in this earlier period. The area within which the earliest faults, trending between east and northeast, occur is marked also by a general dip of the rocks to the north and northwest and stands in both respects in contrast to the Highland quadrangle, in which both the trend of the faults and the strike of the rocks are roughly north-south.

so Longwell, C. R., Structural studies in southern Nevada and western Arizona : Geol. Soc. America Bull., vol. 37, p. 561, 1926. 


\section{LATER NORMAL FAULTING}

Most of the normal faults of the district, including the main north-south faults, are later than the thrust faults. Evidence for the later faulting lies in a minor degree in the faulting of the overthrust block at the north end of the Bristol Range, where it is cut by several small faults that average N. $60^{\circ}$ E. and by a larger northwest fault along the east base of the range near the Lucky Star mine, which drops the overthrust plane several hundred feet, to a level below that of the adjacent wash. The synclinal character of the thrust fault between the West Range and the Bristol Range is also due to later disturbance, either folding or faulting, probably the latter.

The chief evidence for later faulting, however, lies in the close relation of these faults to the present topography of the district. The later faults in the southern part of the Bristol Range quadrangle and in the Highland quadrangle trend roughly north and south, and it is the movement that produced these faults which has determined the north-south trend of the topography. Any topographic effects of the earlier normal faulting or of the thrust faulting are lost so far as the present large topographic features are concerned.

Many of the larger faults, those which have produced the main ranges, are concealed beneath the valley wash, but border faults, parallel to them, are found, particularly along the west side of the Highland and Bristol Ranges. Others of the series lie well within the range.

The latest normal faulting was of the typical Basin Range type. On the west side of the Ely Springs Range, in the Monument Canyon region, and at the south end of the West Range the rocks dip west. Elsewhere they dip east. But, as shown on Plate 1, there is in this area of eastward-dipping strata a succession of outcrops of the lower formations of the Cambrian which requires a succession of fault blocks dipping east. Besides the monoclinal blocks of this type there are structural grabens, well shown by the infaulted block of Mendha limestone that makes much of the east side of the Highland Range from Arizona Peak to a point south of Dead Deer Canyon. A small structural horst shows along the west base of the Bristol Range north of Blind Mountain Spring.
The date of this last faulting is probably late Tertiary. It was later than the Tertiary (?) lavas, for they have everywhere been tilted by it. It was earlier than the Panaca water-laid tuffs, for they lie essentially unchanged in their original position. It is possible that the tuffs may have undergone slight warping, but no evidence of faulting was seen in them. Further, it is clear, as shown in the discussion of physiography (p. 3), that the latest faulting antecated the Panaca formation by a sufficient time to permit erosion to reduce the fault blocks to maturity and to essentially the form which the country has to-day. So far as concerns the Pioche district, faulting is not now in progress and has not been in progress in recent geologic time-perhaps not since the beginning of the Pleistocene.

The Ely Range, both topographically and structurally, is out of alinement with the Highland Range to the west. As a range it trends northwest. In general the strike of the rocks is northwest and the dip northeast. The neighboring lavas agree with the sedimentary rocks in dip and strike. The main faults parallel the range or cut across it at a slight angle; other faults cross the main faults nearly at right angles. Taken as a whole, the Ely Range is regarded as having taken its present form under the influence of the same later faulting that shaped the Highland Range.

\section{BRECCIATION}

Brecciation, with later cementation, often accompanying faulting, has commonly occurred in both quartzites and limestones. A good example in the quartzite is seen along the east base of the Ely Range at the Wide Awake mine. Here a fault separates the Pioche shale from the Prospect Mountain quartzite on the west of it, and the quartzite is thoroughly brecciated for perhaps 20 to 40 feet from the fault plane. The breccia was later cemented by quartz to a hard rock which rises as rough ledges above even the unbroken quartzite just to the west.

Brecciation of the limestone, often apparently. without faulting, has in many places caused the replacement of the bedded rock by massive rock. The ledge of massive jasperoid east of Scotty Wash, just south of Silverhorn, which has been unsuccessfully mined, was probably formed by a siliceous replacement of a limestone breccia. 


\section{Part 2. ECONOMIC GEOLOGY}

By Adolpe Knopf

\section{GENERAL FEATURES OF THE ORE DEPOSITS}

The ore bodies of the Pioche and surrounding districts comprise both oxidized and unoxidized deposits. The oxidized deposits predominate in number, but during recent years the unoxidized deposits have yielded the most ore. The distinction between the two classes is natural to make, because the deposits differ greatly in appearance and composition. The unoxidized or primary deposits consist chiefly of silver-lead-zinc ores. As a result of oxidation the primary ores have been much changed, and the changes produced have been influenced by the nature of the country rock in which the ore deposits are inclosed. The oxidized deposits that are inclosed in quartzite are silver-lead ores, for the zinc they originally contained was largely eliminated during oxidation. Copper in commercial amount occurs with the other metals in some of the ores, as at Bristol, and tungsten in the form of wolframite is a minor constituent in others.

Manganese oxides, derived from the oxidation of manganiferous siderite, are common in the ore deposits in limestone. Some ores, in fact, are valuable chiefly as manganese-iron fluxes, and the ore of the Jackrabbit mine contains so much manganese and is so low in silver, lead, and zinc that it is utilized as a manganese ore in iron smelting.

For descriptive purposes the ore deposits fall more conveniently into three groups-fissure veins in quartzite, mineralized granite porphyry, and replacement deposits in carbonate rocks. All of them appear to have been formed at the same time, in the epoch of mineralization that occurred shortly after the granitic rocks and their allied dikes of granite porphyry and lamprophyre were intruded.

First in point of historic interest and total output are the fissure veins that are inclosed in the Lower Cambrian quartzite. They are the veins on which the prosperity of Pioche was based during the boom days of the early seventies. They occur mainly at the town of Pioche. The ore is highly oxidized and consists of silver chloride, argentite, cerusite, and galena in a quartzose gangue, which is chiefly brecciated quartzite. It is comparatively low in lead.

The second group of ore bodies consists of lenses in a highly sericitized granite porphyry of the Yuba dike. The metalliferous minerals are like those in the veins in the quartzite, but the gangue is soft sericitized porphyry. As the fissure veins in quartzite are situated near the Yuba dike, this association of the veins with the ore-bearing porphyry has strongly colored local ideas on the origin of the ores and has influenced prospecting campaigns in search of undiscovered ore.

The third group comprises the replacement deposits in limestone and dolomite. This group can be subdivided into replacement fissure veins and bedded replacement deposits.

The replacement fissure veins dip steeply and cut across the bedding of the carbonate rocks in which they are inclosed. They are thoroughly oxidized so far as disclosed by the workings, none of which have penetrated to water level, and they are highly manganiferous and limonitic and low in silica. Their size in many places was obviously determined by the intensity of brecciation of the limestone which the fissures traverse. At certain horizons bedded replacement deposits extend out as lateral branches from the fissure veins. Deposits of this type occur mainly in the Lyndon limestone, Highland Peak limestone, and Mendha limestone-a stratigraphic range of 5,500 feet.

The bedded replacement deposits that are attracting most attention have been formed by replacement of the limestones that are inclosed in the Pioche shale. Some of the most productive of these ore bodies, such as the Combined Metals ore bed, do not crop out, and were found accidentally during mining; but after the fact was understood that there are ore bodies in the district of a kind radically different from the fissure veins in quartzite, on which the early prosperity of Pioche was based, other bedded replacement deposits were discovered by systematic diamond drilling.

The geologic position of the bedded replacement deposits, or ore beds, as they are locally called, was determined by the intersections of certain steeply dipping fissures with the favorable limestone beds. These fissures themselves may carry some high-grade ore but are commonly poorly mineralized and thin; consequently they are of inconspicuous or insignificant appearance. Bedded deposits may make off from these fissures at the several successive limestone horizons. At the Prince mine there are at least six such horizons of bedded ore one above another-four in the Pioche shale, one in the overlying Lyndon limestone, and another still higher, at the base of the Highland Peak limestone.

The ores of the region show no particular relation to the mass of intrusive granitic rocks (quartz diorite, 
granodiorite, and quartz monzonite) that occurs north of Stampede Gap. A broad belt of contact-metamorphic rock surrounds the mass, but no productive mines have been developed near it. The immense body of andradite garnet rock at the Manhattan mine is manifestly a result of the intrusion. The nearest intrusive granite to Pioche is a small body of white, highly sericitized rock northwest of the Ely Valley mine, 2 miles northwest of Pioche. Dikes of granite porphyry occur but are scarce. The best-known dike is that called the Yuba, which has been highly sericitized and in places rendered ore-bearing. A few lamprophyre dikes also have been found.

The granitic rocks and the dikes of granite porphyry and lamprophyre were intruded during a single epoch of igneous activity, at the end of which the ore deposits of the region were formed. The precise geologic age of the epoch of mineralization is not known, but it may have been Tertiary.

At a much later time dikes of glassy dacite and rhyolite were injected, but this epoch of igneous activity was not followed by an aftermath of ore deposition.

The Pioche region is greatly faulted, and the faulting occurred at several different times. That there were three epochs of faulting has been proved, and probably there were more (pp. 42-44). With reference to the ore deposits, premineral, mineral, and postmineral faults can be recognized. In the search for ore the distinction between these three classes is likely to be of importance.

The displacement along the fissures occupied by the veins is generally small; in few does it exceed some tens of feet, and in others, as in the Mendha vein, no displacement has occurred. As in many other mining districts, the master faults, however, are not mineralized. Postmineral movement has broken the continuity of some of the ore bodies by closely spaced step faults. It is probable that movement has recurred along certain faults during two or even more epochs of faulting.

\section{OXIDATION AND WATER LEVEL}

The water level in the mines is deep. It is shallowest at the Prince mine, being there at a vertical depth of 496 feet, but this relative shallowness is due to the fact that the mine is out on the flat. At the Kaymond \& Ely mine the water level when cut in the early seventies stood at 1,200 feet, but in later years as a result of drifting operations it sank to 1,400 feet, the water having evidently been drained off through a fissure that was cut by the later workings. All the cther mines are dry.

The ores in the fissure veins are oxidized down to water level. The bedded replacement ore bodies in limestone, most of which dip at low angles, have also as a rule been thoroughly oxidized, but some of them, such as the Combined Metals ore bed, have remained intact, although they are hundreds of feet above the water level. This immunity to oxidation is due to their being inclosed in shale, which forms the foot and hanging walls, and their ends and sides are sealed off from percolating water by impervious postmineral gouge.

Other replacement deposits, as those of the Prince mine, are so thoroughly oxidized that no relicts of the primary mineral from which the abundant manganese oxides were derived can be found in them. Only in the analogous replacement deposits that occur below water level in the Prince mine has the primary manganese mineral so far been found-a highly manganiferous siderite, or manganosiderite.

Sphalerite has disappeared from all oxidized ores; in the siliceous ores the zinc that was liberated by the cxidation of the sphalerite has disappeared completely, but in those ores which are in a limestone or dolomite environment the zinc occurs as smithsonite and calamine. Pyrite has altered to limonite and hematite. The galena has in part altered to cerusite and locally to the soft ocherous plumbojarosite, and in part it has remained intact. Copper appears as chrysocolla, carbonate, and copper-pitch ore. The silver, unknown in its primary form, occurs as chloride.

The prevalence of basic sulphates among the oxidation products is noteworthy. The basic ferric lead sulphate, plumbojarosite, has already been mentioned, but jarosite is much more common. Potassium was obviously present in effective concentration in the oxidizing solutions. Probably the general limestone environment kept the acidity of the oxidizing solutions low and so favored the formation of basic sulphates.

The abundant manganese oxides that occur in many of the ore bodies of the area are the result of the oxidation of manganosiderite, as is suggested by the occurrence of that carbonate in the deeper workings of the Prince mine below water level. The iron oxides and hydrates-"limonite," goethite, and hematite-that are associated with the manganese oxides are also in part the result of the oxidation of the manganosiderite and in part of the oxidation of pyrite.

During the oxidation of the ores of the Pioche district the opportunities for enrichment appear to have been small. The siliceous ores were somewhat raised in grade by the removal of zinc and part of the iron, but this appears to be the extent to which the ores were enriched. The silver was altered to cerargyrite, apparently without supergene enrichment. In the ores in limestone the abundance of calcite appears to have prevented any extended migration of metals and hence any enrichment. However, zinc may have migrated into the footwall country rocks of some of the ore 
bodies while they were oxidizing, and therefore the possibility that bodies of zinc carbonate may occur in the limestone that underlies an oxidized lead-silver body should be kept steadily in mind.

\section{MINERALOGY}

Some notes on the minerals that occur in the ore deposits are given below.

Andradite.-A brown garnet of the calcium-ferric variety, andradite, occurs in immense quantity at the Manhattan mine. Microscopically it is seen to inclose some magnetite. Pyrite is commonly associated with the andradite, but most of it has been oxidized to limonite. In the hand specimen the andradite appears to be oxidizing and yielding limonite; under the microscope it is found to be altering to a deep yellowish-red mineral, which is in part isotropic and in part shows aggregate polarization.

Andradite is known to be easily susceptible to attack by a dilute solution of sulphuric acid, and such solutions are likely to occur in an environment of oxidizing pyrite. In the presence of copper-bearing solutions andradite thus attacked yields chrysocolla. ${ }^{31}$ At Morenci, Ariz., the andradite decomposes to quartz and limonite, presumably as the result of oxidizing acid attack. ${ }^{82}$

Arsenopylite.-Arsenopyrite has been found by J. L. Gillson to occur as a minor constituent of the fissure ore of the Prince mine.

Brannite.-The manganese silicate braunite $\left(3 \mathrm{Mn}_{2} \mathrm{O}_{3} \cdot \mathrm{MnSiO}_{3}\right)$ was identified by Gillson as an abundant component in the oxidized ores of the Prince mine. It was not recognized before polished sections of the ore were microscopically studied, as the largest grains are so small as to be entirely overlooked even with the microscope except when high magnification is used. The braunite occurs as minute crystalline masses and stringers in the limonite. Under the reflecting microscope its color is like that of hematite, but its relief is lower. It is slightly harder than the limonite in which it occurs. Ore containing 14 per cent of manganese and consisting only of braunite, limonite, and gangue will give gelatinous silica when treated in a test tube with hydrochloric acid.

Dufreynosite.-According to Gillson, "In one specimen of siliceous ore from the Prince mine dufreynosite probably occurs in very minute amount. When the polished surface of the ore was examined under the reflecting microscope a few grains of a galeng-white mineral were distinguished at points of contact of the blebs of tennantite or the other probable silver-bearing minerals. The contrast in color at such points made the galena-white mineral distinguishable from the galena. FOH is the only one of the usual reagents that reacts with the mineral. It darkens the surface faintly. These chemical tests and the hardness and color are those of the rare mineral dufreynosite $\left(\mathrm{Pb}_{2} \mathrm{As}_{2} \mathrm{~S}_{5}\right)$, but this identification could not be conflrmed because of the small quantity of the mineral available."

Hematite.-Frematite occurs abundantly as a pseudomorph after pyrite in oxidized manganese-iron ore of the Prince and Virginia Louise mines. As a brick-red ocher it is commonly associated with the limonite in the oxidized ores in limestone.

A hard blackish iron oxide forming porous pseudomorphs after a carbonate (calcite, or more probably a manganosiderite) is extremely abundant; its red or red-brown streak sug-

"Knopf, Adolph, Geology and ore deposits of the Yerington district, Nev. : U. S. Geol. Survey Prof, Paper 114, pp. 33, 48, 1918.

Lindgren, Waldemar, The copper deposits of the Clifton-Morenc district, Arlz. : U. S. Geol. Survey Prof. Pnper 43, pp. 109, 177-178, 1905. gests that it is hematite, but as it gives some water in the closed tube it is probably "turgite," or hydrohematite.

Hydrozincite.-A soft dull-white mineral, hydrozincite, $\mathrm{ZnCO}_{3} .2 \mathrm{Zn}(\mathrm{OH})_{2}$, occurs in the oxidized zinc-bearing ores at a number of localities. The tests relied on to establish its identity are its effervescence in hydrochloric acid, yield of water in the closed tube, and zinc content.

Hydrozincite is abundant in ore from the 300-foot level of the Gypsy workings of the Bristol mine. Examined in oils the powder shows fibrous, radial aggregates, giving fan-shaped sectors. The fibers give parallel extinction and positive elongation; the indices exceed $\mathbf{1 . 6 4}$.

At the Fortuna prospect, just north of the Jackrabbit mine, the hydrozincite checks after exposure on the dump. It proves to be isotropic or locally shows faint aggregate polarization; its refractive index is 1.66. Evidently this hydrozincite is just crystallizing from the gel state.

Jarosite.-Jarosite, a basic sulphate of potassium and ferric iron, $\mathrm{K}_{2} \mathrm{Fe}_{0}(\mathrm{OH})_{12}\left(\mathrm{SO}_{4}\right)_{4}$, is common in the oxidized ores of the district. It is generally in the form of a soft yellow ocher of unctuous feel; in places it occurs as hard, compact masses It is most common in the veins that are inclosed in limestone and is particularly abundant in the surface ore of the May Day vein, in the Bristol area.

The prevalence of jarosite as an oxidation product of the ores in limestone is perhaps somewhat surprising, as to form jarosite potassium must necessarily have been present in the oxidizing solutions, and limestones are not particularly prolific sources of potassium. However, as jarosite is a basic salt, and as the formation of basic salts is favored by hydrolysis, which in turn is favored by a neutral or alkaline condition of the solution from which the salt is precipitated, jarosite is likely to be produced in a limestone country, where the sulphuric acid formed during oxidation will necessarily be rapidly neutralized. Neutralization of the acid will facilitate the oxidation of the iron to the ferric condition and its subsequent precipitation in basic compounds. As a matter of observation jarosite is more common in arid than in humid regions and is most abundant in limestone country. ${ }^{33}$

Leverrierite.-A white mineral of exceedingly smooth feel and high waxy luster occurs in considerable abundance in the oxidized copper-lead-zinc ore of the 950-foot stope of the Bristol mine and is locally called talc. Under the microscope it is seen to be a finely felted aggregate that resembles sericite. The fibers give parallel extinction and positive elongation; $\gamma=1.575$ and $a=1.55$. It does not swell in water or become plastic. After being dissolved in hydrofluoric acid it does not give a potassium flame, though it gives a weak copper flame, probably owing to a minute amount of adsorbed copper. It is accordingly identified as leverrierite.

Manganosiderite.-See Siderite.

Phosgenite.-The rare mineral phosgenite (chlorocarbonate of lead, $\mathrm{PbCO}_{3} \mathrm{PbCl}_{2}$ ) was identifled by J. L. Gillson as occurring in the fissure ore of the Prince mine. It forms a coating on massive pyrite, and in this coating are embedded innumerable small crystals of pyromorphite.

Plumbojarosite.-As a yellowish ocher of smooth, talclike feel plumbojarosite in small amounts is common in the oxidized ores of the district. It resembles the much more abundant jarosite, from which it can not be distinguished by visual inspection. The plumbojarosite mentioned in this report has been verified by the blowpipe test of yielding lead beads and by its optical properties. In this way it was found to occur notably at the Comet mine associated with galena, sphalerite,

ss Locke, Augustus, Leached outcrops as guides to copper ore, p. 107, 1926 , 
and wolframite, and in lesser quantities elsewhere in the district.

In recent years plumbojarosite has been shown to occur in many of the mining districts of Nevada-in the Goodsprings district, Clark County, especially at the Boss mine, famous for its platinum-palladium ore; in the Arabia district, Pershing County ; and in the Simon district, Mineral County.

Pyrargyrite.-According to Gillson, two other minerals besides tennantite form minute blebs in the galena of the Prince mine, both in the fissure ore and in the residual galena in the oxidized bedded ore. The only one of these identified is pyrargyrite. Its certain recognition was hindered by the fact that the polished surface of the mineral when tested with KOH under the microscope is not affected, whereas most pyrargyrite is attacked by $\mathrm{KOH}$. It was identified by comparison with standard material by the use of a comparative ocular. The other mineral remains unidentified. When examined under the reflecting microscope it shows a dark grayish-white color and reacts only with $\mathrm{KCN}$, like the pyrargyrite. Also like the pyrargyrite, it is sectile but does not give a red powder when scratched. It is probably a silver-bearing mineral.

Pyrargyrite was also identified as occurring in the highgrade silver-bearing lead ore of the Greenwood fissure in the Combined Metals mine.

Pyrolusite.-Pyrolusite $\left(\mathrm{MnO}_{2}\right)$ is one of the most abundant manganese minerals in the oxidized manganiferous ores. At the Black Metals mine it is well crystallized, commonly occurring as fan-shaped and radial groups, some of which are as much as an inch or two in diameter.

Siderite.-A manganiferous siderite occurs in the primary sulphide ore of the Prince mine on the 835-foot level, which is 300 feet below the top of the water table. It is a white carbonate having moderately curved cleavage surfaces. The index $\epsilon^{\prime}$, measured on the cleavage rhomb, is about 1.72, which indicates a manganiferous siderite. The following carefully made analysis gives the actual composition.

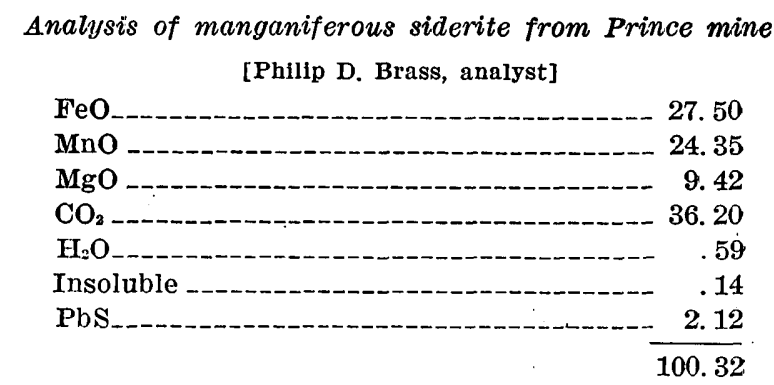

Calcium was proved to be absent. The PbS represents a small amount of galena finely disseminated through the carbonate.

This manganiferous siderite, or manganosiderite, is regarded as typical of the carbonate from which the manganese and part of the iron in the manganiferous iron ores of the Prince and other mines were derived by oxidation.

Tennantite.-Tennantite $\left(\mathrm{Cu}_{3} \mathrm{As}_{2} \mathrm{~S}_{7}\right)$ was detected by Gillson as a microscopic constituent of the fissure ore in the Prince mine. It proved to be a variety that is affected in polished section by KCN, an unusual property for that mineral.

Vanadinite.-Vanadinite occurs very rarely as a yellow coating or bloom on the galena of the Prince mine. It is abundant in minute sharp hexagonal prisms in some manganiferous ore found in a prospect pit near the Combined Metals shaft.

Willemite.-Willemite $\left(\mathrm{Zn}_{2} \mathrm{SiO}_{4}\right)$ was found by Gillson to occur abundantly as a coating of millimeter-sized crystals on oxidized ore in a prospect on the east side of the crest of Arizona Peak.

Wolframite.-The tungsten ore mineral wolframite, $(\mathrm{Fe}, \mathrm{Mn}) \mathrm{WO}_{3}$, occurs in the Comet vein and in the Panaca vein, a few hundred feet north of the Comet. It is embedded in the quartz gangue of the Comet vein as tabular crystals that are half an inch thick and as much as 2 inches in diameter. It is associated with galena and a brilliant black sphalerite which closely resembles it. In the Panaca vein wolframite is the only metalliferous mineral that occurs with the quartz; galena, sphalerite, and pyrite appear never to have been present.

\section{VEINS IN QUARTZITE}

The silver-bearing veins in the Lower Cambrian quartzite were the basis of the astonishing results achieved during the early seventies. Raymond could virite in 1872 that never in the history of the world had such an output been attained. For a brilliant four years Pioche was second only to the Comstock lode. The ores carried from 75 to 150 ounces of silver, or $\$ 100$ to $\$ 200$ to the ton. From 40 to 85 per cent of the silver in the ores occurred as chloride. As a rule the ores were low in lead.

The chief veins that occur in the quartzite are at Pioche and in its immediate neighborhood. The only exception is the Comet vein, 9 miles from Pioche, which is interesting and peculiar in that it contains wolframite in noteworthy amount along with galena, sphalerite, and pyrite.

The most productive vein in the quartzite was the Raymond \& Ely. It was as a rule of moderate width but locally expanded to 9 feet. By 1874 it had already been practically exhausted down to water level at 1,200 feet; subsequently it was worked to an extreme depth of 1,400 feet. It strikes nearly west and dips $75^{\circ} \mathrm{S}$., traversing quartzites that dip $20^{\circ} \mathrm{N}$. East of shaft 3 it splits into two branches, known as the Meadow Valley and Burke veins, the angle of divergence between which is $20^{\circ}$.

The filling of the veins in quartzite consists chiefly of angular fragments of quartzite, and the metalliferous minerals occupy the interspaces between the fragments. In the upper levels the ore is porous owing to leaching, probably in the main. the result of the removal of sphalerite and pyrite; it contains lead carbonate, silver chloride, and other oxidation products in minor quantity. Galena appears in less thoroughly oxidized ore, and black sphalerite occurs in cre below water level.

In recent years the most brilliant result attained by working the fissure veins in quartzite was at the Stindt $\&$ Donohue lease, on the Wide Awake group, 2 miles south of Pioche. In $1919 \$ 120,000$ worth of ore, averaging $\$ 60$ a ton in silver and lead, was shipped from this lease. The ore, although in a fissure vein in quartzite, is unusual in that it dips at angles as low 
as $20^{\circ}$ to $30^{\circ}$. Because of this low dip, the ore has been erroneously called " bedded ore," but it occupies a fault fissure, probably a thrust fault, which cuts through the quartzites, here dipping $45^{\circ} \mathrm{N}$.

Considerable development work is now being done by the Pioche Mines Co. in cleaning out and extending the old workings on some of the quartzite fissure veins that are associated with the $\mathrm{Yuba}$ dike, such as the Mazeppa and Chapman.

\section{ORE BODIES IN GRANITE PORPHYRY}

Shoots of ore occur in a granite porphyry dike known as the Yuba dike, which cuts through the quartzite on Treasure Hill south of the town of Pioche. Il has often been asserted that the Yuba dike is the source of all the ore in the district and that consequently the ore bodies are poorer the farther they are from the dike. Were this assertion strictly believed, it would powerfully deter much legitimate prospecting. One of the results of a broader interpretation of the belief that the Yuba dike is an ore bringer is that much expensive exploration has been done in the vicinity of other dikes that have been mistakenly regarded as similar to the porphyry of the Yuba dike. For example, certain dikes of glassy andesite, dacite, and ihyolite have been thought to be like the granite porphyry of the Yuba dike and hence likely to be ore bringers; but as a matter of fact they were intruded long after the time at which the ore of the district was formed. That these dikes are younger than the ore is best shown at the Hamburg mine, where a glassy dacite (technically a hornblende-biotite dacite vitrophyre) cuts through the ore body.

The Yuba dike contains shoots or pods of ore distributed irregularly through it; they occur sporadically at both contacts or anywhere in the interior of the dike. The dike is 40 feet thick, trends east, and dips $80^{\circ} \mathrm{S}$. It cuts through the quartzite, which dips $25^{\circ} \mathrm{N}$., and it has been traced as far east as the Alps mine. The dike consists of biotite granite porphyry whose most conspicnous feature is its porphyritic quartz. It has been called a "quartz porphyry," which is an excellent noncommittal descriptive name for it, and "rhyolite porphyry," which is less appropriate. It has been highly sericitized, and practically the only original mineral left is the quartz that occurs in the groundmass and as many small porphyritic crystals. Where unoxidized the porphyry contains finely disseminated pyrite, which was manifestly put into the porphyry at the time it was sericitized.

In general the dike is shattered, and at intervals it contains thin lenses of ore lying in its plane and bounded by well-defined walls. The quartzite along the contact of the dike is shattered, and in places "quartzite fissures" extend out into the quartzite from the dike at angles of roughly $45^{\circ}$ with its course. Genetically it is clear that the Yuba dike was shattered after it had solidified and that it then served as a channelway along which hot solutions ascended. These solutions deposited galena, sphalerite, pyrite, and a silver-bearing mineral in the dike and altered all its feldspar and biotite to white silky mica (sericite).

A large amount of work was done on the Yuba dike and its related quartzite fissures by the "old timers" and subsequently by lessees. Most of it was done on small tracts, on many of which deep shafts were sunk, some as deep as 1,200 feet. As a result the ore that was taken out could have been found with one-third of the work that was actually done. At the present time most of the ground is owned by the Amalgamated Pioche Mines \& Smelter Corporation and is under lease to the Pioche Mines Co., which has begun more systematic development than was possible under divided control.

\section{REPLACEMENT DEPOSITS IN CARBONATE ROCKS}

\section{GENERAL FEATURES}

The replacement deposits in carbonate rocks (limestone and dolomite) are of two kinds-replacement fissure veins, formed by replacement along fissures that cut across the bedding; and tabular ore bodies that lie parallel to the bedding and are generally referred to locally as bedded ore bodies, formed by replacement of certain limestone or dolomite beds. In some mines both kinds are associated in a single ore system, for at certain horizons tabular masses of ore extend out from the ore-bearing fissure into the limestone like branches from the main trunk of a tree.

The replacement ore deposits where unoxidized are silver-bearing pyrite-sphalerite-galena bodies. They range from solid sulphide masses to ores that are more or less manganiferous. The manganiferous ores are highly oxidized, consisting of pulverulent oxides of iron and manganese and containing negligible amounts of lead, zinc, and silver. In fact, at the Jackrabbit mine pyrolusite $\left(\mathrm{MnO}_{2}\right)$ is so abundant and lead, zinc, and silver are so nearly absent that the material is shipped to the iron smelter near Provo, Utah, as manganese ore.

Around the periphery of many of the replacement deposits in limestone is a zone of coarse interlocking white calcite, in which the individuals of calcite show cleavage surfaces as much as 6 to 8 inches in diameter. This coarse calcite has resulted from the recrystallization of aphanitic limestone; the explanation seems to be that the spent or depleted ore-forming solutions, though no longer able to replace the limestone that surrounds the ore bodies by ore, were able to recrystallize it. 
The following analyses show the great purity of this calcite :

Analyses of calcite from Pioche district

[J. G. Fairchild, analyst]

\begin{tabular}{|c|c|c|c|}
\hline & 1 & 2 & 3 \\
\hline \multirow[t]{2}{*}{ 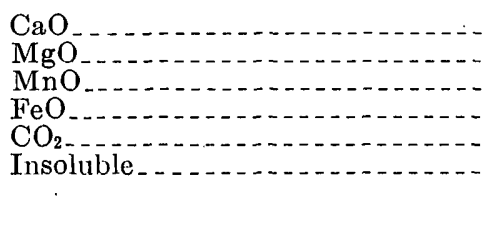 } & $\begin{array}{r}55.77 \\
.20 \\
.07 \\
\text { None. } \\
44.09 \\
.21\end{array}$ & $\begin{array}{r}55.33 \\
.70 \\
\text { Trace. } \\
\text { None. } \\
44.23 \\
.05\end{array}$ & $\begin{array}{r}54.66 \\
.27 \\
1.11 \\
\text { None. } \\
43.92 \\
.16\end{array}$ \\
\hline & 100. 34 & 100. 31 & 100. 12 \\
\hline
\end{tabular}

1. Virginia Louise mine, west drift, 400 -foot level.

2. Jackrabbit mine, 800-foot level.

3. Tempest mine, dump.

FISSURE VEINS

The replacement fissure veins are most notably represented in the Bristol area. The May Day, Gypsy, Tempest, and Hillside veins are among the most prominent. . They yield silver-bearing copper-leadzinc ores, all highly oxidized. Galena in small amounts is the only sulphide found.

The veins occupy steeply inclined fissures that cut through the gently dipping beds of the Highland Peak limestone. The ore occurs in shoots, whose position appears to have been determined, in part at least, by the places at which fault breccia was developed along the fissures. Angular fragments of limestone occur in the ore, and they become larger and more abundant toward the ends of the shoots. That these breccias were not produced by mineralization stoping ${ }^{34}$ is indicated by the fact that breccia also occurs in portions of the faults where there is no ore.

Contrary to an opinion expressed that these ores were deposited from downward-moving solutions, ${ }^{35}$ there is no reason to doubt that the primary ores were deposited from ascending solutions. During oxidation, however, there has been some rearrangement of the metals, but not much, on account of the prevalence of limestone. The copper has tended to move toward the footwall, where it was precipitated as chrysocolla and copper pitch; the iron, manganese, and zinc have also probably moved a little, but the lead, altered from galena to cerusite, has remained in place.

\section{TABULAR REPLACEMENT DEPOSITS ("BEDDED ORES")}

In recent years the bedded ore of the Combined Metals mine at Pioche has been of main interest. During 1926 this mine was producing at the rate of

a Locke, Augustus, The formation of certain ore bodies by mineralization stoping: Econ. Geology, vol. 21, pp. 431-453, 1926.

(s Hill, J. M., Notes on some mining districts in eastern Nevada : U. S. Geol. Survey Bull. 648 , p. $129,191.6$.
4,000 tons a month. The ore is practically a solid sulphide aggregate that consists of an intimate intergrowth of pyrite, sphalerite, and galena. The pyrite predominates, and the zinc content is 14 per cent, lead 7 per cent, silver 7 ounces to the ton, and gold 0.03 ounce to the ton. This ore was worthless until a proper flotation was devised. So intimately are the sulphides intergrown that the ore must be ground to 200-mesh in order that the lead and zinc can be separately concentrated by selective flotation.

The ore body occur's at the intersection of a steep fissure (the Greenwood) and a limestone bed dipping $20^{\circ}$ that occurs in the Pioche shale. It extends out laterally on both sides of the fissure as much as 100 feet. The ore has clearly been formed by replacement, as all the peculiarities of the original rock, such as its distinctive nodular character, are retained and preserved. The ore body is a tabular mass 30 to 40 leet thick, thickest adjacent to the Greenwood fissure and tapering away from it. The downward extension of: the ore body is determined by the angle of intersection that the Greenwood fissure, which strikes $\mathrm{N}$. $65^{\circ} \mathrm{E}$. and $\operatorname{dips} 65^{\circ} \mathrm{N}$., makes with the limestone bed, which dips gently southwest.

The Greenwood fissure has yielded some high-grade silver-bearing lead ore near the replacement ore bed. It is known as a result of recent diamond drilling that the Greenwood fissure has caused replacement by ore in another limestone bed lying 118 feet above the main ore bed, but the amount of this ore is not yet determined. It is an interesting fact that the Greenwood fissure and the Raymond \& Ely fissure are closely adjacent, trend nearly parallel, and dip in opposite directions. Whether the Raymond \& Ely vein has caused the development of replacement ore where it intersects the limestone beds in the Pioche shale appears not to be known.

The bedded replacement ores at the Prince mine, 3 miles southwest of the Combined Metals mine, differ considerably in composition and degree of oxidation from that at the Combined Metals mine. Those above water level are thoroughly oxidized and consist of manganese-iron oxides low in silver, lead, and zinc. About 800,000 tons of ore carrying $2 \frac{1}{2}$ to 3 ounces of silver to the ton, 3 per cent of lead, 35 per cent of iron, and 15 per cent of manganese has been shipped. Ore of this kind contains also 1 per cent of zinc, which vitiates its possible use as a manganiferous iron ore. The bed known as the Twenty-foot bed, which is in the Pioche shale near the top of that formation, has been the most profitable. It was mined for a length of 1,500 feet and for a maximum width of 400 feet. The bed was mined on the contract system, and the ore was delivered at the shaft for 40 cents a ton. Besides the Twenty-foot bed four other beds of manganiferous flux were worked. 
Unoxidized sulphide ore was found by diamond drilling to have replaced one of the lower limestones in the Pioche shale. This bedded ore is 340 feet below water level, which stands at 496 feet below the collar of the Prince shaft. The ore consists of sphalerite, galena, and pyrite in a gangue of manganiferous siderite and minor quartz. Oxidation of such a manganiferous siderite and pyrite would account for the abundant iron and manganese in the bedded ores that are above water level. Another sulphide bed 245 feet below this one is indicated as the result of diamond drilling and appears to be only 10 feet above the Prospect Mountain quartzite (Lower Cambrian).

The mineralizing fissure from which these seven successive horizons of bedded ore were developed appears to be the Great Western fault. Along this fault considerable vertical movement took place, part of which was postmineral; it did not, however, exceed 400 feet, for the Lyndon limestone, which is only 400 feet thick, occurs at the surface on both sides of the fault.

\section{SILVER-BEARING JASPEROID AT SILVERHORN}

Immense outcrops of jasperoid occur near the now abandoned mining camp of Silverhorn, 4 miles north of Bristol Pass. The largest are hundreds of yards long and hundreds of feet wide, forming conspicuous dull-brown masses that make the ridge tops. A coarse gray fossiliferous limestone of Mississippian age is the prevailing country rock.

In places the seams that traverse the jasperoid are splotched with films of horn silver, and the high assays that were obtained from sampling these films lcd to the boom that ran its short-lived course in 1921. Much bona fide prospecting in the form of long tunnels and inclines was done. The longest tunnel cuts a mass of jasperoid at a depth of 200 feet below the outcrop; it shows a body of jasperoid 80 feet thick, which was formed along a fault contact, the hanging wall being shale and the footwall limestone. This jasperoid is the normal fine-grained siliceous rock that is formed as the result of the replacement of limestone by minutely crystalline quartz.

\section{GENESIS OF THE ORE DEPOSITS}

The ore deposits of the region appear to be all of essentially contemporaneous origin: although there are slight differences in age among them they were all formed during one epoch of mineralization. They were formed in the interval between the injection of the dikes of granite porphyry and lamprophyre and the injection of the Tertiary dikes of glassy dacite. That is the positive evidence. Other, less certain evidence indicates that they were formed shortly after the granite porphyry and lamprophyre dikes were in- truded. According to Ferguson, ${ }^{36}$ there were four metallogenetic epochs in Nevada-(1) epi-Jurassic, contemporaneous with that in the Sierra Nevada; (2) Eocene; (3) pre-Esmeralda (before upper Miocene); and (4) post-Esmeralda. It is the writer's belief that the mineralization in the Pioche region was either epi-Jurassic or Eocene.

The pyritic andradite mass at the Manhattan mine is an ore body of high-temperature origin, and consequently the conditions necessary to form it could have been brought about only by the intrusion of the quartz monzonite mass of Blind Mountain. Between the andradite deposits and the productive ore deposits there is a genetic gap, for it is true in general that the minerals that occur in the productive ore deposits are not of particular genetic significance. The quartz in the fissure veins in the quartzite, however, is of the coarse milky-white kind, and this feature, together with the thoroughness with which the ore-forming solutions have sericitized the granite porphyry, indicates that the ores were formed under conditions of moderate temperature and pressure; they are mesothermal deposits.

The main elements carried by the ore-forming solutions were $\mathrm{Ag}, \mathrm{Pb}, \mathrm{Zn}, \mathrm{Cu}, \mathrm{S}, \mathrm{Fe}, \mathrm{Mn}$, Si, and $\mathrm{K}$. This is a conventional generalization, however, and it is unlikely to be true of the solutions that rose along every trunk channel. There were individual differences; at Bristol the solutions probably carried more copper, for they precipitated more copper, and at Comet they carried tungsten. The silica was deposited in the form of quartz in the fissure veins that lie in quartzite, but quartz was rarely deposited in the limestones. The manganese, on the other hand, was not deposited in the veins in the quartzite but was deposited abundantly by replacement of the limestones. Possibly as the ore-depositing solutions became cooler the precipitation of the manganese was accelerated, as appears to be the explanation at Butte, Mont., where the manganiferous ore was precipitated in the outermost, coolest zone of ore deposition; and as the manganosiderite in the primary deposits of the Pioche district is of replacement origin, which implies that the manganese was supplied from the trunk channels by diffusion, the temperature at the frontiers of replacement as the ore body grew laterally from the feeding fissure was considerably lower than in the trunk channels up which the ore-forming solutions rose through the quartzite.

Ore is not known to have been deposited as a result of the Tertiary volcanic activity. The considerable mass of opal that occurs north of the Ely Valley mine

${ }^{30}$ Ferguson, H. G., Regional relations of Nevada ore deposits [abstract] : Washington Acad. Sci. Jour., vol. 17, pp. 121-122, 1927; The mining districts of Nevada: Econ. Geology, vol. 24, pp. 115-148, 1929. 
is the only evidence of any mineralizing activity later than the epoch of ore deposition, and it may have been formed at the vent of a hot spring.

The ore bodies in the limestone and dolomite are essentially replacement deposits. In the fissure veins it was fault breccia that was replaced, with some concomitarit replacement of the wall rocks. In the bedded ores certain limestone and dolomite beds were replaced laterally from mineralizing fissures. The Combined Metals ore bed, so far as yet known, is the most "favorable" bed. What determines the favorableness of a carbonate rock for replacement by ore is one of the profound enigmas of geology. It can not be chemical composition, for dolomite, which differs greatly in composition from' limestone, has also been replaced by ore, as at the Mendha mine. Furthermore, it can not be the thinly bedded nature of the Combined Metals ore bed, for in reality that bed is tripartite, consisting of a lower massive member 3 feet thick, an intermediate barren layer 3 feet thick, and an upper thin-bedded nodular limestone 30 feet thick. In places only a part of the ore bed has been altered to ore, but in some such places it is the lower portion of the thin beds that has been transformed to ore and in others it is the lower massive member. Locally certain thin beds are nearly solid galena; it would be a normal mental reaction to say that these beds "were obviously more favorable to replacement by galena than the adjacent beds," but nothing is really explained by that restatement. 'The "favorableness" of a limestone as a repository of ore is a purely inductive fact, a conclusion based on observation, and can not be foretold.

The Combined Metals bed is stratigraphically the lowest favorable bed. There is a suggestion that this ore bed conforms to one of the generalizations announced by Prescott ${ }^{37}$ for the limestone replacement deposits of Mexico: "The first favorable limestone encountered by the ascending mineralizer is often by far the most productive." The development of the Pioche district, however, has not yet progressed far enough to give much weight to this suggestion. Possibly the "zinc bed" at the Prince mine, so far known only by diamond drilling, which is stratigraphically below the Combined Metals bed-in fact, is only 10 feet above the Lower Cambrian quartzite-may prove to be of economic value. Ore occurs also in the other limestones higher in the Pioche shale, as well as in the overlying Lyndon limestone, Highland Peak limestone, and Mendha limestone-a total stratigraphic range of 5,500 feet. At no one mine, however, do bedded ores occur through such a range. The maxi-

57 Prescott, Basil, The underlying principles of the limestone replacement deposits of the Mexican province: Eng. and Min. Jour., vol. 122, p. $247,1926$. mum range so far demonstrated at any one mine is 1,500 feet at the Prince, where at seven horizons, ranging from near the base of the Pjoche shale to the base of the Highland Peak limestone, rock has been replaced by ore. The deposits at the higher horizons have here been removed by erosion, and the evidence that they might have given as to the maximum possible number of ore beds at any one locality has been destroyed.

The evidence that the ore was formed by replacement is best displayed in the thin-bedded portion of the Combined Metals ore body, where every detail of the nodular beds is faithfully preserved in the ore. Toward the periphery the ore is somewhat higher in pyrite. In the Silver ore bed at the Prince mine, which is undoubtedly the equivalent of the Combined Metals bed, the sequence of minerals is manganosiderite, quartz, and sulphides. 'This order of deposition appears to be the result of the inability of manganosiderite to persist during the process of ore deposition in too hot an environment; at first manganosiderite was deposited near the feeding fissure, but as the temperature gradually increased by conduction it was replaced by quartz and sulphides, moved outward, and was reprecipitated. It thus constituted the vanguard of the replacing minerals. Under appropriate conditions of temperature and concentration of the manganese, however, large bodies of manganiferous ore were deposited.

That many of the ore bodies are surrounded by a thick shell of coarsely crystalline calcite has already been mentioned, and it was suggested that this was the work of the ore-forming solutions after they had been depleted of their metalliferous constituents; possibly such coarsely crystalline calcite was the most advanced member of the vanguard in front of the growing ore body. At any rate this prevalence of coarse spar helps to explain the common poikilitic texture shown by much of the leaner manganiferous ore in such ore bodies as the Twenty-foot bed of the Prince mine. During the oxidation of the primary ore the manganese and iron have migrated somewhat and, coming into contact with the coarse spar, have partly replaced it, sufficiently to blacken and disguise its calcitic nature but not enough to destroy the calcite cleavage; hence the luster-mottled surfaces so common in the ore.

What is the nature of the feeding fissures through which the ore-forming constituents of the tabular replacement were supplied? This is a matter of much practical importance, for the feeding fissures are sure guides in the search for other ore bodies. It is by no means easy to establish whether or not a given vein or fissure was the feeding channel. Some veins are younger than the bedded ores and merely intersect them; and some fissures, on the other hand, are post- 
wiineral faults. A greater difficulty in interpretation arises if the mineralizing fissure has also been the site of severe postmineral movement.

The best-known mineralizing fissure is the Greenwood, up which were brought the substances from which the Combined Metals ore body was formed. The evidence that it was the mineralizing fissure lies in the facts that the downward extension of the ore body is governed by the angle of intersection of the fissure with the ore bed and that ore occurs adjacent to it where it cuts a limestone bed approximately 100 feet above the Combined Metals bed. The Greenwood fissure itself contains some ore, both above and below the ore bed, but in general is a very insignificantlooking fissure. Further details are given in the description of the Combined Metals mine (pp. 55-56).

\section{SUMMARY AND CONCLUSIONS}

The bonanza output of the Pioche district came from the fissure veins in the Lower Cambrian quartzite. In the space of four years the two mines that worked the principal vein-the Raymond \& Ely vein-were able to disburse $\$ 4,981,000$ in dividends, so successful were they despite the great handicaps placed on them by what was then a remote desert mining camp. The known ore was rapidly exhausted, but it was mined skillfully in spite of its richness, and the ground was carefully explored for more ore. ${ }^{38}$ The upper levels were gone over several times. Although the ore then mined was of much higher grade than would now be necessary for profitable working, yet in view of the explicit emphatic statements in Raymond's reports on the skill and thoroughness with which the ore was extracted and of the history of other Nevada camps, in which it has been found that most or all of the ore has been carefully mined out by the "old-timers," it seems overoptimistic to expect to find bodies of bonanza ore or large quantities of moderate-grade ore in the old-time workings.

There is a possibility that some of the fissures that are thin and feebly mineralized in the Pioche shale may become stronger and carry ore where they extend clown into the underlying quartzite. The bonanza ore of the Raymond \& Ely vein did not come to the surface at the Lightner shaft but was cut at a depth of 200 feet, after the shale which there overlies the quartzite had been penetrated. The ore shoot whose top was thus cut yielded several millions. At other localities the distinctly adverse effect of the Pioche shale on the veins is likewise clearly shown. On the other hand, veins like the Greenwood fissure, which carry high-grade ore near their intersections with limestone, are conspicuously barren in the quartzite.

\footnotetext{
Saymond, R. W., Mineral resources of the States and Territories west of the Rocky Mountains for 1872, p. 180, 1873.
}

The recognition in recent years that large replacement ore bodies have formed in the limestones interbedded with Pioche shale where the limestones are cut by certain mineralized fissures has greatly enhanced the possibilities of the district. The limestone (the "Combined Metals ore bed") 250 feet above the base of the shale has so far been found to be the most productive stratum. As demonstrated at the Prince mine, a single fissure can have caused replacement ore bodies to form at six or seven successively higher limestone horizons.

The successive limestone beds thus replaced occur not only in the Pioche shale but also in the overlying Lyndon limestone and the still higher Highland Peak limestone. Accordingly, it may be worth while to explore to considerable depths those mineralized fissures that yield ore in the formations above the Pioche shale on the chance that the lower favorable limestones, especially those in the Pioche shale, have been replaced by ore.

The practicability of prospecting these lower limesione beds depends on several factors, one of which is their depth below the surface or below the deepest workings of the particular mine in which such prospecting is contemplated. The geologic column showing the order of superposition and the thickness of the several formations is therefore of supreme practical importance. Because of the acutely faulted condition of the region, especially in the immediate vicinity of Pioche, the construction of this column became possible. only after the extended areal surveys of the whole region by Professor Westgate, and it is one of the chief objects of this report to make this column available for such exploratory work. It shows that the Combined Metals bed, so far the most favorable bed known, is 870 feet below the top of the Pioche shale and about 1,400 feet below the bottom of the Highland Peak limestone.

That large valuable bodies of bedded replacement ore have formed adjacent to insignificant fissures has already been pointed out; it is beyond doubt one of the impressive features in the geology of the district. It opens the possibility that there may occur many such bedded deposits that do not crop out. To find these ore bodies will be difficult, but their discovery will be facilitated primarily by applying skillfully a knowledge of the geologic column and by determining the faulting that has disturbed or changed the normal sequence of the strata.

\section{THE MINES}

COMBINED METALS MINE

The Combined Metals mine, in recent years the most productive mine in the Pioche district, is at the west edge of the town of Pioche. It is operated on a royalty basis by the Combined Metals Reduction Co., 
under a lease from the owner, the Amalgamated Pioche Mines \& Smelter Corporation. The mine is connected by a narrow-gage railroad with the Union Pacific terminus at Pioche. The ore is shipped to the company's flotation plant at Bauer, Utah, where lead and zinc concentrates are made, which are then sent to the smelter. Experimental work is now going on at this plant to extract the lead and zinc directly from the complex ore by a hydrometallurgical process using newly devised machinery and chemical methods. The power plant of the mine is steam driven and is fired by Utah coal, which costs $\$ 6$ a ton delivered at the mine. Early in September, 1926, the power plant and head frame were destroyed by fire, but they have since been replaced.

The mine is worked through a vertical 2-compart- ment shaft, the No. 1 shaft of the old Raymond \& Ely Co. The collar of the shaft is 6,346 feet above sea level. The shaft is 1,272 feet deep, and from it seven levels have been driven; the bottom level, at a vertical depth of 1,272 feet, is known as the 1,200. Other workings, which, however, are exicluded: from the present lease, extend down by a number of winzes to the 1,400-foot level.

During 1926 ore was being hoisted from the 350 , 420 , and 720 foot levels, and exploratory drifting and crosscutting was being done on the 1,200-foot level. Diamond drilling also was used to locate faulted segments of the main ore body and to discover whether any stratigraphically higher ore beds occur.

Water level was originally struck on the 1,200-foot level, but subsequently it dropped to the 1,400-foot level.

\section{HISTORY}

The ore body worked is a tabular replacement mass consisting of intimately intergrown pyrite, sphalerite, and galena, named in the order of decreasing abundance. It is called bedded ore. Such complex sulphide material was of no value until selective flotation was invented. According to S. F. Whitney, manager of the Amalgamated Pioche Mines \& Smelter Corporation, this ore had been found by the early operators but, being without value at that time, was of no interest to them. Much later it was rediscovered by a Mr. Greenwood in a long crosscut driven from what is now known as the Greenwood shaft. After a celebration in honor of the discovery it was found that the ore was not on the property controlled by Greenwood. The discovery locality is on the present 420 -foot level of the Combined Metals mine.

To E. H. Snyder belongs the credit of demonstrating that the bedded ore is an economic asset. This was done by proving the extent of the deposit by exploring it from the Greenwood workings and then driving back to No. 1 shaft. Furthermore, under his direction proper flotation procedure was devised, without which the material would have remained metallurgically worthless.

Ore was first shipped to the Combined Metals Reduction Co.'s plant at Bauer, 1 mile from Stockton, Utah, on May 19, 1924. During the first seven months of 1926 the output was 4,000 tons a month, but owing to the disastrous fire the rate was seriously curtailed during the remainder of the year. The output to the middle of September, 1926, aggregated 112,000 tons of a gross settlement value of roundly $\$ 1,500,000$. This ore has been remarkably constant in composition, averaging 14 per cent of zinc, 7 per cent of lead, 7 ounces of silver to the ton, and 0.03 ounce of gold to the ton.

Composition of Combined Metals ore

\begin{tabular}{r|r|r|r|r}
\hline Year & $\begin{array}{r}\text { Gold } \\
\text { (ounce } \\
\text { to the ton) }\end{array}$ & $\begin{array}{r}\text { Silver } \\
\text { (ounces } \\
\text { to the ton) }\end{array}$ & $\begin{array}{r}\text { Lead (per } \\
\text { cent) }\end{array}$ & $\begin{array}{r}\text { Zinc (per } \\
\text { cent) }\end{array}$ \\
\hline 1925 & 0.037 & $\begin{array}{r}7.96 \\
6.85\end{array}$ & $\begin{array}{r}6.74 \\
6.27\end{array}$ & $\begin{array}{r}14.41 \\
13.48\end{array}$ \\
\hline
\end{tabular}

a First 5 months.

GENERAL GEOLOGY

The ore bodies are in a belt of Pioche shale that trends northwest and lies between two master faults. On the northeast the shale is bounded by the Prospect Mountain quartzite and on the southwest by the Lyncon limestone. The main ore body is the result of a replacement of a certain limestone member in the Pioche shale, 250 feet above the base of that formation. The replacement, however, occurred only where the limestone member is intersected by a steeply dipping fissure known as the Greenwood. The belt of shale within which the ore bodies occur is dislocated by many transverse faults, which have broken the continuity of the ore body.

The Pioche shale in the vicinity of the mines has the normal character of that formation. The shale is arenaceous-in fact, in places it contains so much quartz that it is a fine-grained sandstone. It is shimmery on the shale fracture surfaces, from the abuncance of detrital flakes of muscovite. The formation contains intercalated limestone members which range in thickness from 1 foot, as near the Greenwood shaft, to 40 feet. This thickest member is of most interest because the portion of it that was replaced by ore constitutes the main ore body ; it is therefore generally known, as the Combined Metals bed. About 118 feet stratigraphically above the Combined Metals bed is a 15-foot member of limestone, which is rather thickly bedded, the thickest bed measuring 3 feet. A few quartzite beds also are intercalated in the Pioche shale. 
The average strike of the formation is $\mathrm{N} .30^{\circ} \mathrm{E}$. and the dip $20^{\circ} \mathrm{NW}$, but the attitude varies considerably in different fault blocks.

The base of the Pioche shale, exposing the underlying Prospect Mountain quartzite, is seen at several places in the mine. It is shown.in a winze level 250 feet below the Greenwood crosscut, which yields the valuable fact that the Combined Metals ore bed is 250 feet above the base of the shale. It is shown also on the 600-foot level, near the powder-house crosscut, und the approximate base appears in the extreme southwest workings on the 1,200-foot level, where it iıs been dropped by a fault trending $\mathrm{N} .20^{\circ} \mathrm{W}$., dipping $65^{\circ} \mathrm{SW}$., and marked by a fault breccia of shattered quartzite 40 feet thick.

The Combined Metals bed is of paramount importance. It consists of three parts-a lower portion consisting of 3 feet of massive limestone; a calcareous sandstone 3 feet thick, which in the ore body is unreplaced and hence is a barren layer that is called the "rib"; and an upper portion consisting of thin-bedded nodular limestones, 30 feet thick. This upper portion is the most distinctive, comprising a series of beds that as a rule are only 2 to 3 inches thick and are commonly so nodular as to suggest that they are made up of layers of more or less flattened potatoes. These nodules are coated with a thin black carbonaceous (?) skin.

Beneath the Combined Metals bed is a quartzite stratum, 6 feet thick, fine grained, vitreous, and obscurely bedded. It has been regarded by some as a limestone silicified by the ore-forming solutions, and the mica flakes in it were thought to have been produced by the same agencies. However, the microscope shows conclusively that it is not a jasperoid but is a quartzite of detrital origin, and the ends of the mica flakes show the contusions characteristic of mica flakes of detrital origin.

Granite porphyry occurs in a small outcrop at the portal of the Zero tunnel, and a steeply dipping dike cf granite porphyry, 60 feet thick and trending N. $70^{\circ} \mathrm{W}$, was cut 300 feet from the portal. It is shattered and hydrothermally altered, and both contacts are fissured and mineralized. It is reported that similar porphyry was found on the 1,200-foot level and deeper workings.

Numerous cross faults have greatly dislocated the continuity of the ore body. Step faulting and trough faulting have occurred, but the resultant effect is to cause the ore body to be at deeper and deeper levels toward the southwest. How much of the faulting was of premineral origin and how much was postmineral has not been determined. The practical effect on the continuity of the ore body from the point of view of the operator would be essentially the same, whether the faulting was premineral or postmineral, because premineral faulting would have sliced the replaceable bed into segments, each of which could have been independently replaced from the mineralizing Greenwood fissure. Postmineral faulting, however, in addition to cutting the ore body into separate segments, would have caused a lateral severance of the Greenwood fissure, and such breaks in the continuity of the fissure by transverse faulting have in fact been recognized. This lateral shifting is therefore clearly the result of postmineral movement, but it may be merely renewal of movement along a premineral fault. Other evidence of postmineral movement is the drag ore that occurs in the cross faults.

The Greenwood fissure is a fault of slight displacement; it is generally of insignificant appearance and js a thin seam of gouge, though locally attaining a maximum thickness of 5 feet. It trends $\mathrm{N} .70^{\circ} \mathrm{E}$. and $\operatorname{dips} 65^{\circ}-70^{\circ} \mathrm{N}$. It strikes nearly parallel to the Raymond \& Ely vein, which, however, dips $75^{\circ} \mathrm{S}$.; according to Mr. A. W. Williams, superintendent, the position of the Raymond \& Ely vein in the Combined Metals mine is not definitely known. The Greenwood fault is reported to be a pivot fault; in the western part of the mine the footwall has been aropped 25 feet relatively to the hanging wall, but this displacement diminishes toward the pivot, and east of the pivot the footwall has gone up relatively to the hanging wall. The Greenwood fissure has been cut off 350 feet below the collar of the shaft and 38 feet east of it by a fault striking N. $30^{\circ} \mathrm{W}$. and dipping $65^{\circ} \mathrm{SW}$. Its eastward extension is probably shown in the Zero tunnel, where it is a normal fault that causes a horizontal displacement of 30 feet as measured along its strike; and adjacent to it 3 to 4 feet of manganiferous silver ore has formed in the Combined Metals bed of limestone.

\section{ORE BODIES}

The main ore body is a tabular mass of sulphides, extending out laterally into the limestone layer. It is thickest, 30 to 40 feet, adjacent to the Greenwood fissure and tapers down away from it. It extends at a. maximum 100 feet on each side of the Greenwood fissure. The greatest horizontal length ("stope iength") of the ore body along the fissure was 500 feet. As the ore body is of replacement origin it can easily be shown that

$$
\begin{aligned}
L & =\frac{40}{\sin \alpha \sin x} \\
\text { where } & \\
L & =\text { horizontal length of the ore body. } \\
\alpha & =\text { angle of dip of limestone. } \\
x & =\text { angle between the strike of the Greenwood } \\
\text { fissure and that of the limestone. } & \\
40 & =\text { thickness of limestone in feet. }
\end{aligned}
$$


As the average angle of dip of the limestone is $15^{\circ}$; the shortest possible stope length is 150 feet where the fissure cuts the bed at right angles; and the closer the strike of the fissure coincides with the strike of the limestone the longer the ore body.

As indicated in the description of the limestone member, the ore body is tripartite; it consists of an "upper bed," 30 feet thick, which is separated by a barren stratum, "the rib," from a lower massive bed, 4 feet thick. The practical problem of mining this ore body has been solved by mining the upper bed first, allowing the ground to cave, and then mining the lower bed.

The ore of the upper bed preserves the nodular character of the limestone for which.it has been substituted. The stopes in it are remarkable examples of replacement, for the ore breaks parallel to the periphery of the nodules, and as the black selvage surrounding the nodules is preserved the ore looks like country rock.

The ore is an intimate intergrowth of pyrite, sphalerite, and galena, named in the order of decreasing abundance. Chalcopyrite is uncommon. The intergrowth is so intimate that it is necessary to grind the ore to 200 mesh in order to obtain clean concentrates from the sulphides by selective flotation. Pyrite makes up roughly 60 per cent of the ore, sphalerite 22 per cent, and galena 8 per cent. Gangue minerals are practically absent.

The ore of the lower bed is massive and not nodular. The bottom of the ore body is not sharp, for the underlying quartzite for a foot or two downward has been irregularly replaced by pyrite and sphalerite. Another peculiarity of the basal portion of the ore body is that in places it has a sort of mock porphyritic texture due to the presence of large well-formed pyrite crystals and irregular, large sphalerite individuals in a fine-grained matrix of sphalerite.

The ore is unoxidized. On fracture surfaces crystals. of cerusite appear sporadically. The ore bodies themselves are dry, although some of the mine levels are fairly wet from downward-seeping water. Manifestly the faulted segments of ore body are impervious, and in spite of being marooned as much as 900 feet above water level they have remained unoxidized.

As already mentioned, the composition of the ore body is remarkably constant. The range is indicated by the following extreme limits as given by settlement assays : Zinc, 10 to 17 per cent; lead, 5.2 to 8 per cent; silver, 6 to 8.5 ounces to the ton; gold, 0.03 to 0.05 ounce to the ton. At the extreme edges of the ore body it becomes somewhat higher in pyrite.

Diamond drilling has recently shown that ore occurs in the Fifteen-foot bed of limestone adjacent to the Greenwood fissure. This bed is reported to be 118 feet stratigraphically above the main ore bed. Some years ago sulphide ore was found in the Fifteen-foot bed on the 300-foot level of the Susan Duster incline. It is of low grade, but it is believed by Mr. E. H. Snyder to be of low grade because it is in a part of the ore body that is distant from the feeding fissure.

Although in general the Greenwood fissure is of unencouraging appearance, being for hundreds of feet in length in the quartzite not more than a thin gougefilled fissure hardly exceeding 6 inches in thickness, yet near the bedded ore body it contains some highgrade ore. It has been stoped as far as 130 feet below and 65 feet above the bedded ore. This ore was much richer in galena than the bedded ore and was high in silver. Both proustite and pyrargyrite occur in this ore and account for its high content of silver.

Former operators discovered on the 1,200-foot level the Black ledge, so called on account of the prevalence of black sphalerite in it. It is in the Lower Cambrian Prospect Mountain quartzite and dips $45^{\circ} \mathrm{S}$. It was worked down to the 1,400-foot level. The ore was quartzose, and as mined it carried from 12 to 20 per cent of zinc, practically no lead, and from 5 to 21 ounces of silver to the ton. During 1914 and 1915 the Amalgamated Pioche Mines \& Smelter Corporation operated a gravity concentration and flotation mill with a daily capacity of 150 tons, using this ore. Operations. were stopped because of the great difference between the assay value of the concentrate produced (about $\$ 100$ a ton) and the smelter settlement value $(\$ 33)$.

\section{PIOCHE MINES CO.}

MINES ON TREASURE HILL

The Pioche Mines Co. owns the Ely Valley mine, West End group, and Wide Awake mine and holds a 15-year lease on all the Amalgamated Pioche Mínes \& Smelter Corporation's ground that lies east of the No. 1 shaft and extends down to the 1,200-foot level, the datum being the collar of No. 3 shaft (the main shaft of the old Meadow Valley Co.). The Ely Valley, No. 10, and Wide Awake mines are described elsewhere in this report; the workings on Treasure Hill are described below.

The leasehold comprises the extensive old workings on the eastward extension of the Raymond \& Ely vein and on the Yuba dike and the fissure veins in quartzite near it, such as the Chapman, Mazeppa, and others on Treasure Hill. The proposed plan of development contemplates putfing electric power at the mouth of the Mazeppa shaft, using that shaft as a central hoisting shaft, hoisting the ore to the level of the Burke tunnel, and hoisting the waste to the surface. The ore is to be trammed to the portal of the Burke tunnel, whence it is to be carried by aerial tram to the reduction plant that has been built at the terminus of the Union Pacific branch line. 
Much of the ground has been worked in small tracts, and an astonishing amount of shafting and drifting has been done by the "old-timers" and lessees. The present operations have so far been devoted chiefly to cleaning out the old workings and putting them into condition for economical working under centralized control. Some new exploratory work has been done, such as drifting eastward on the Yuba dike from the face of the Burke tunnel. In 1926 the old No. 3 shaft on the Raymond \& Ely vein was retimbered for the purpose of examining the deeper workings on the Burke and Meadow Valley branches of the vein.

The Burke tunnel, which is situated on the north slope of Treasure Hill and overlooks the town of Pioche from an altitude of 6,250 feet, trends S. $13^{\circ} \mathrm{E}$. and crosscuts the Lower Cambrian quartzite, which dips $20^{\circ} \mathrm{N}$. It intersects the Burke vein (a "quartzite fissure"), then another vein in the quartzite, and finally the Yuba dike. Extensive lateral workings west of the tunnel have explored several of the fissure veins in quartzite (the Chapman vein, the Mazeppa vein, and others) and also the Yuba dike. The socalled quartzite fissures, of which the Chapman vein is a typical representative, are veins in which the filling ranges from a loose rubble of angular quartzite fragments to a breccia cemented by lead carbonate, limonite, and jarosite. They range in thickness from a few inches to a few feet; the high-grade streak is admittedly narrow. They are obviously of highly siliceous composition, and whether they are of ore grade can be determined in advance of extraction only. by systematic sampling and assaying. It is reported that in the Chapman workings 50,000 tons of ore, of unknown grade, has been put in sight.

Farther east the Yuba dike is cut at a considerably lower altitude by the Pacific tunnel, which is 1,200 feet long. At the intersection the dike was crosscut for 25 feet, and a shoot of ore was found, 4 or 5 feet thick, the remnants of which are said to be milling ore. The east end of the drift on the dike is at the 150-foot station of the shaft of the Mascot Silver Mining Co., the successor of the Boston-Pioche Mining Co. It is reported that in this part of the dike a shoot was found that was 100 feet long and 2 to 3 feet thick and that carried 57 per cent of lead and 157 ounces of silver and $\$ 10$ in gold to the ton. This ore was found by following a "quartzite fissure" into the porphyry, a circumstance that falls well in line with the reasonable belief that the porphyry dike after it had been shattered was a trunk channel along which ore-forming solutions rose. The general features of the Yuba dike, which are remarkably constant over the exposed portion of the dike, are described on page 49 .

89276-31-5

\section{ELY VALLEX MINE}

The Ely Valley mine, owned by the Pioche Mines Co., is 2 miles northwest of Pioche. It is developed by an inclined shaft 515 feet long, sloping $63^{\circ} \mathrm{SW}$., from which three levels have been turned, at vertical depths of 123, 268, and 428 feet. From the 300 -foot level (vertical depth 268 feet) a winze, starting on the vein, was sunk vertically 300 feet, and from the bottom of this winze a crosscut was being driven southwestward in 1926 to intersect the quartzite contact. The power plant consisted of a 40-horsepower gas engine, but during 1926 an additional engine of 100 horsepower was installed.

The Ely Valley vein crops out in the Lyndon limestone, but in depth, just above the 300-foot level, it passes into the underlying Pioche shale. As seen in the old shaft just south of the present shaft the vein is 20 feet thick and consists of a porous cavernous mass of siliceous manganiferous "limonitic" ore, which is reported to carry $\$ 20$ to the ton in silver, lead, and gold. It is clearly shown that the ore was formed by the replacement of a brecciated limestone. Some bodies of sand carbonate were found in the upper workings. The vein is quartzose on the 200 -foot level, the gangue consisting largely of milk-white quartz, and after passing into the underlying Pioche shale, 35 feet above the 300 -foot level, it pinches to a few inchés in thickness, though still quartzose. It trends $\mathrm{N} .75^{\circ}$ $W$. and is nearly vertical.

The west workings of the 300 -foot level show much bedded siliceous manganiferous iron material carrying little or no lead and silver; this material has been formed by the replacement of limestone. Much of the iron oxide is porous hematite, apparently pseudomorphic after a carbonate, probably siderite. A bed of siliceous manganiferous oxide 20 feet thick was cut in the winze, 72 feet below the 300 -foot level.

The Pioche shale encountered in the deeper workings of the mine consists of hard siliceous beds, best ciescribed as shaly sandstones. On bedding surfaces they have a marked silvery shimmer from abundant small flakes of detrital muscovite; hence they are locally called "mica schists." The beds dip $10^{\circ}-30^{\circ} \mathrm{N}$.

The fault that separates the Lyndon limestone from the Prospect Mountain quartzite, 500 feet southwest of the shaft, is a major fault on which the dip slip has been about 1,700 feet. It was cut in depth by the shaft, which disclosed a crushed zone 6 to 30 feet thick. Near the fault contact some copper ore carrying chrysocolla was found.

\section{NO. 10 MINE}

The No. 10 mine, owned by the Pioche Mines Co., is at the foot of the Ely Range, 2 miles northwest of Pioche. 
It is opened by an incline and an adit. About 200 . tons of ore was mined for experimental purposes.

The ore body is a banded vein that conforms in strike and dip to the inclosing rocks; it is a bed vein. It strikes N. $30^{\circ} \mathrm{E}$. and dips $10^{\circ}-20^{\circ} \mathrm{NW}$. It is inclosed in the Pioche shale; the footwall is shale, and the hanging wall is a quartzite bed 5 feet thick that

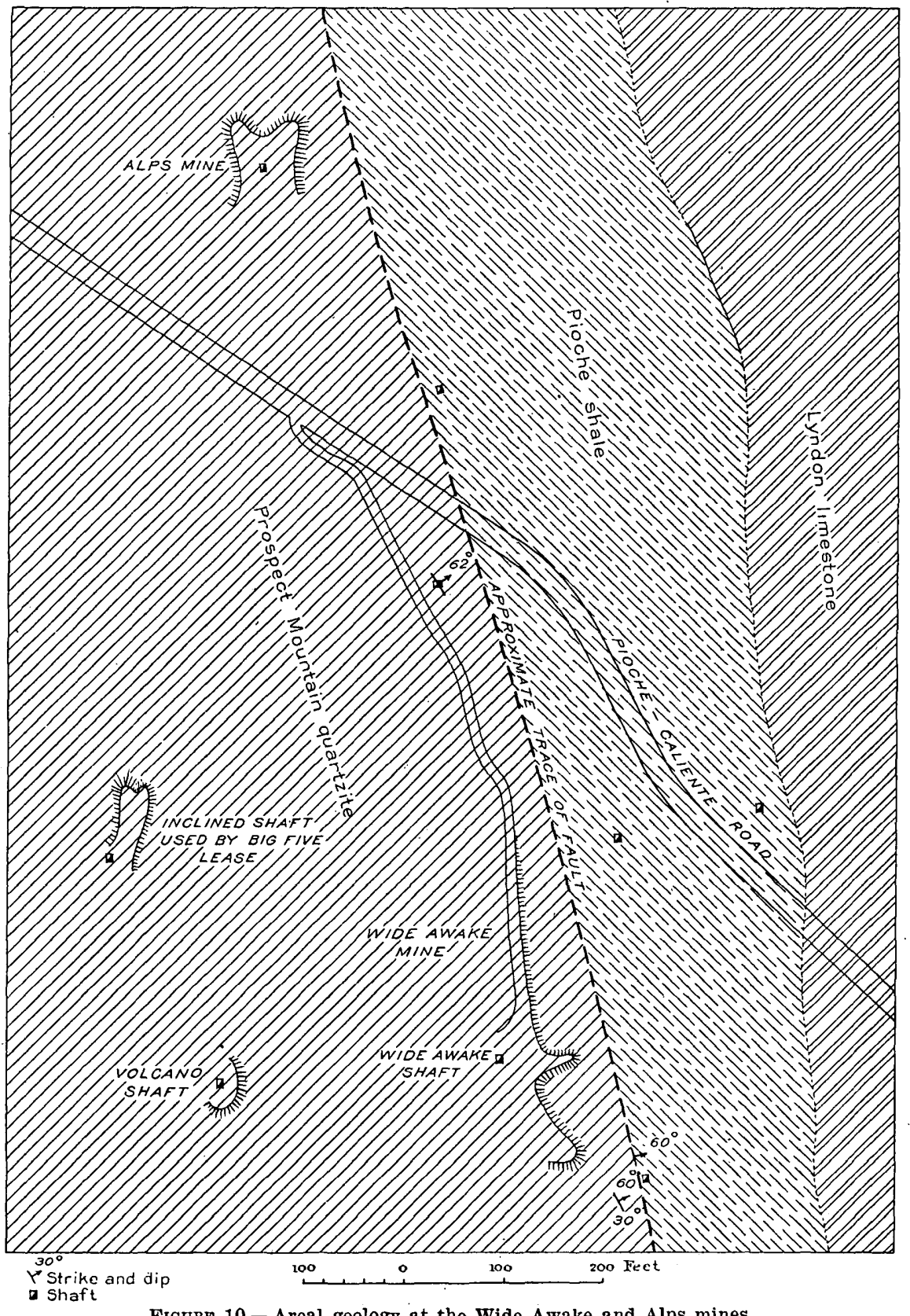

POORMAN MINE

The Poorman mine is 1 mile south of Pioche and is east of the Caliente road. It is owned by the Pioche Mines Co. and is reported to have produced $\$ 300,000$. During 1926 it was idle and its workings were mostly inaccessible.

The country rock at the mine is the Prospect Mountain quartzite. The most notable surface feature is the immense knob of quartzite breccia that occurs west of the main shaft. The chief vein strikes N. $70^{\circ} \mathrm{E}$. and dips $30^{\circ}-45^{\circ} \mathrm{S}$. Besides this vein an irregular series of small veins were worked, which strike N. $40^{\circ}-70^{\circ} \mathrm{W}$. and $\operatorname{dip} 45^{\circ} \mathrm{E}$. The ore is of the siliceous silver-lead variety, in which the lead occurs as carbonate.

WIDE AWAIKE MINE

The Wide Awake mine is $11 / 2$ miles south of Pioche, on the west side of the highway to Caliente. It is owned by the Pioche Mines Co.

The principal development is an inclined shaft (the Wide Awake) sloping $81^{\circ} \mathrm{NW}$., from which five levels have been run, the bottom, or 500-foot level, at a vertical depth of 402 feet. The development below the 500-foot level is accomplished by means of a winze 196 feet deep sunk from this level at a point about under the Dupont shaft. From the bottom of this winze a drift is being run northward to cut the Yuba dike. The chief mechanical equipment is a 40 horsepower gasoline hoist and a 60 horsepower semi-Diesel direct-connected compressor.

The main output has come from the workings generally called the Stindt \& Donohue lease. During 1919 these two lessees took out about 2,000 tons of siliceous lead-silver ore, valued at $\$ 120,000$, or $\$ 60$ a ton. The following smelter returns on 40 -ton lots indicate the character of the ore: underlies one of the limestone layers in the Pioche shale. The vein is like the Abe Lincoln but occurs in a much lower stratigraphic position. The vein averages 6 inches in thickness. The ore is generally oxidized, but galena occurs in places. It is reported to assay $\$ 20$ a ton, carrying $\$ 6$ in gold and 7 ounces of silver to the ton and 6 per cent of lead.
Smelter returns on ore from Wide Awake mine

\begin{tabular}{|c|c|c|c|c|c|c|c|}
\hline $\begin{array}{l}\text { Gold } \\
\text { (ounce } \\
\text { to the } \\
\text { ton) }\end{array}$ & $\begin{array}{l}\text { Silver } \\
\text { (ounces } \\
\text { to the } \\
\text { ton) }\end{array}$ & $\begin{array}{c}\text { Copper } \\
\text { (per } \\
\text { cent) }\end{array}$ & $\begin{array}{l}\text { Lead } \\
\text { (per } \\
\text { cent) }\end{array}$ & $\begin{array}{c}\text { Iron } \\
\text { (per } \\
\text { cent) }\end{array}$ & $\begin{array}{l}\text { Silica } \\
\text { (per } \\
\text { cent) }\end{array}$ & $\begin{array}{l}\text { Zinc } \\
\text { (per } \\
\text { cent) }\end{array}$ & 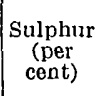 \\
\hline $\begin{array}{l}0.045 \\
.13 \\
.34\end{array}$ & $\begin{array}{r}72.8 \\
151.4 \\
24.1\end{array}$ & $\begin{array}{r}0.18 \\
.30\end{array}$ & $\begin{array}{l}11.55 \\
57.15 \\
10.70\end{array}$ & $\begin{array}{r}14.00 \\
3.05 \\
14.40\end{array}$ & $\begin{array}{l}39.8 \\
15.4 \\
58.1\end{array}$ & $\begin{array}{c}4.15 \\
\end{array}$ & $\begin{array}{r}0.35 \\
4.50 \\
.55\end{array}$ \\
\hline
\end{tabular}


The formation at the mine is the Prospect Mountain quartzite. (See fig. 10.) The quartzite is as a rule of the normal hard glassy variety, but in places it: is feldspathic and sericitic and hence is somewhat soft, even punklike. In the mine workings the quartzite is in general regularly bedded and undisturbed, striking N. $30^{\circ}-40^{\circ}$ W. and dipping $45^{\circ}-65^{\circ}$ E. At the surface, however, there are many large outcrops of recemented quartzite breccia, which, being harder than the formation itself, weather out in relief as bold masses. The explanation of this prevalence of breccias at the surface is probably that the surface locks are a shattered mass that overlies a thrust fault. The superposition of the brecciated quartzite on the underlying bedded quartzite is well shown at the Spring shaft.

A normal fault that lets down the Pioche shale against the quartzite is exposed 120 feet east of the Wide Awake shaft; it trends northwest. It has been crosscut on the 200-foot level; here the workings are already below the base of the shale, and consequently both the footwall and hanging wall of the fault are quartzite. The fault dips $60^{\circ} \mathrm{E}$., and the fault zone is a clay gouge 4 feet thick. This fault has also been cut on the 500-foot level, where the quartzite in the footwall of the fault is regularly bedded and dips $60^{\circ} \mathrm{E}$., whereas that in the hanging wall is highly disturbed and dips $0^{\circ}-20^{\circ} \mathrm{E}$., and this disturbed condition persists as far as the quartzite was penetrated, 300 feet.

The ore body is a vein that dips $20^{\circ} \mathrm{SE}$. Because of its low dip it has been called a bedded vein, but this term is wholly unjustified, for the quartzite beds below the vein dip $25^{\circ}$ more steeply eastward than the vein. The overlying quartzite is so highly disturbed that its dip can not be measured. The low dip of the fault along which the ore occurs suggests that the fault is an overthrust whereby the quartzite beds of the hanging wall were shoved over the footwall beds and severely brecciated.

The ore consists of lead carbonate in a quartzite. gangue. One edge of the Stindt \& Donohue ore shoot approached close to the surface and was thus discovered; the upward extension of the remainder was cut off by a fault that strikes N. $30^{\circ} \mathrm{W}$. and dips $70^{\circ} \mathrm{E}$. This fault is clearly a normal fault, as the vein steepens against it. (See fig. 11.) The ore shoot extended at a maximum 90 feet down the dip (eastward) from the fault. Below this the extension of the vein has not yet been certainly determined.

Some ore of similar kind has been found on the 300 -foot level; it is at most $1 \frac{1}{2}$ feet thick. It appears to be nearly horizontal and is overlain by 3 to 4 feet of brecciated quartzite.

\section{ALPS MINE}

The Alps mine is on the Caliente road $11 / 2$ miles south of Pioche. It is one of the oldest mines in the district; in 1871 the shaft had already been sunk to a depth of 115 feet. ${ }^{39}$ The ore was of high grade and yielded $\$ 80$ a ton in silver and gold. The total output to date is said to be about $\$ 800,000$. The mine is owned by the Alps Mining Co., which is controlled by the Lloyd estate. In recent years it has been idle. It is developed by a 2-compartment vertical shaft, 300 feet deep, from which levels extend at depths of 150 , 200 , and 300 feet.

The general country rock is the Prospect Mountain quartzite, which strikes N. $20^{\circ} \mathrm{W}$. and dips $30^{\circ}-40^{\circ} \mathrm{N}$. The shaft penetrates 30 feet of wash, 20 feet of shale, 25 feet of quartzite, and 15 feet more of shale and then enters quartzite containing no intercalated shale. The upper quartzite layer is severely brecciated, and

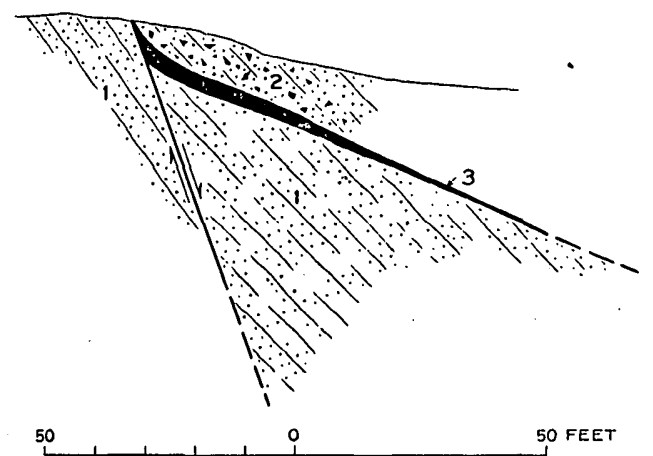

FigưR 11.-Section through Stindt \& Donohue ore shoot. 1, Prospect Mountain quartzite; 2, brecciated quartzite; 3 , vein

the shales are commonly reduced to gouge. A thrust fault dipping $35^{\circ} \mathrm{NE}$. is shown on the 150 -foot level, and all the rocks above it have been reduced to a breccia or gouge. This thrust fault suggests that the damaged condition of the rocks in the shaft is likewise due to thrust faulting.

The mine workings are almost entirely in the quartzite, which as a rule is regularly bedded. In the bottom level the Yuba dike of granite porphyry has been cut 150 feet southwest of the shaft; it is here 40 feet wide, dips $70^{\circ}$ S., and, as everywhere else along its course, is highly sericitized. Another drift on this level fails to show this dike, although it intersects the strike of the dike only 100 feet farther east, so that the dike appears to have been cut off by a fault.

The ore occurs in fissures and brecciated zones in the quartzite and consists of lead carbonate in a quartz gangue. It is unusually white, which indicates that the primary ore did not contain much pyrite.

Raymond, R. W., Statistics of mines and mining in the States and Territories west of the Rocky Mountains for 1871, p. 248, 1872. 
The main vein strikes N. $80^{\circ}$ E. and dips $70^{\circ} \mathrm{S}$. It ranges in general from 1 to 4 feet in thickness, though in places it has been stoped out to a width of 7 feet. The ore has been largely removed from the surface down to the bottom level. Recently some $\$ 200$ ore was found in an east-west vein on the bottom level, but stoping had hardly begun when the workings holed through to the bottom of a stope that extends downward from the level above. On the east the vein is cut off by a fault that strikes $\mathrm{N}$. $55^{\circ} \mathrm{W}$. and dips $55^{\circ} \mathrm{NW}$. In depth the vein terminated against shale. This shale is an intercalated member of the quartzite formation, such as occurs elsewhere in the district, but it is of no great thickness. The contact of the shale with the overlying quartzite is shown in the bottom level; it strikes north and dips $35^{\circ}$ E. A gouge, from which a little water issues, has formed along the contact, which, therefore, has been a plane of movement. This movement has probably dislocated the vein. It appears reasonable to expect that by judicious exploration the downward extension of the vein may be discovered.

\section{PRINCE AND VIRGINIA LOUISE MINES}

The Prince and Virginia Louise are two adjoining mines that are now controlled by the Prince Consolidated Mining Co. More than a million tons of crumbly black material carrying 15 per cent of manganese, 30 per cent of iron, 3 per cent of lead, and 2 or 3 ounces of silver to the ton has been shipped from these mines. The Prince mine was for several years the premier producer of lead in Nevada. The ore so far mined was obtained above water level, and most of it occurred as oxidized replacement deposits in a series of limestone beds that are separated from one another by siliceous low-grade ore or by barren shale. Below water level bedded sulphide ore has been found but has not yet been worked.

\section{LOCATION AND OWNERSHIP}

The mines are on the southwest side of the Ely Range, 21/4 miles southwest of the town of Pioche, in sec. 33, T. 1 N., R. 67 E. The altitude of the Virginia Louise shaft is 5,830 feet, and that of the Prince vertical shaft is 5,855 feet. The mines are connected with the Union Pacific system at Pioche by a standardgage railroad that extends around the northwest end of the Pioche Hills.

The Prince mine consists of 4 patented claims, 1 patented fraction, and 14 unpatented claims, altogether covering 386 acres. The Virginia Louise owns one patented claim and two unpatented claims, 50 acres in all, immediately south and west of the Prince property. The company owns in addition the Pioche
King group of nine claims and 1,000 acres of patented land at Dry Valley and 200 acres of patented land at Bullionville.

\section{OUTPUT}

The output from the Prince mine by the Prince Consolidated Mining \& Smelting Co. up to 1920 amounted to 746,804 dry tons, which yielded 1,806,188 ounces of silver, $43,588,850$ pounds of lead, and $\$ 145,395$ in gold, of a total value of $\$ 7,000 ; 000$ gross. Operations were suspended in August, 1921.

The output of the Virginia Louise Mining Co. from 1915 to 1921 was 65,410 dry tons, which yielded 190,997 cunces of silver and 4,484,000 pounds of lead. The mine was idle in 1922, but in April, 1923, it was leased to the Virginia Louise Development Co., work was renewed and up to September, 1924, about 30,000 tons of ore had been shipped.

\section{HISTORY}

The property was first located in the early sixties and is said to have shipped much fluxing ore to the old Pioche smelters and occasionally some high-grade ore to the Utah plants. An old shaft, open cuts, and trenches were made by the early-day miners in search of the richer pockets of galena in the iron-manganese oxide ore.

The Prince Consolidated Mining \& Smelting Co. was organized in 1907 by James L. Hackett, of Louisville, Ky., and the Godbe Brothers, of Salt Lake City. Ore was hauled by teams to Panaca, on the branch railroad from Pioche to Caliente, which had been built in 1907. The Godbe Brothers also controlled the tailings from the old mills at Bullionville, and in 1911 they built a spur from Bullionville to the CalientePioche track near Panaca. They then shipped a large tonnage of the tailings to Salt Lake City smelters. With the money made by this venture a standard-gage railroad 8.71 miles in length was built from Pioche to the Prince mine and finished on June 30, 1912.

The Virginia Louise Mining Co. was incorporated in 1912 and began work late in that year, sinking a shaft to reach the supposed extension of the Prince cre beds. The shaft and upper levels were completed before the end of 1913, and a large amount of ore was blocked out, but the World War closed the market for this low-grade fluxing ore, and it was not until September, 1918, that shipment began. Earlier in 1918 the property had been entirely reequipped and development work resumed. Litigation between the Virginia Louise Mining Co. and the Prince Consolidated Mining \& Smelting Co. during 1917 and 1918 ended in favor of the Virginia Louise Co., which obtained a judgment of $\$ 27,334$ for trespass. A compromise was then effected whereby the Prince Consoli- 
clated Mining \& Smelting Co. dismissed the apex suit that it had filed against the Virginia Louise Mining Co. and granted to that company the right to ship ore over the Prince private railroad in return for release from the trespass judgment.

The Prince Consolidated Mining \& Smelting Co. was very active in the years from 1912 to 1921. Large ore bins were built in 1912 and the large ore body was developed. The first mining was done by caving methods, but the shrinkage or filling system was later adopted. Some diamond drilling had been clone before 1913 and was continued later. Altogether four cores were obtained in the Prince ground. At a depth of 835 feet from the surface the No. 3 drill cut 5 to 6 feet of silver-zinc-lead ore of good grade. This body was also cut at a like depth by another hole 250 feet distant, indicating that the body is a bedded cieposit. At a depth of 1,113 feet the No. 3 drill cut another body of ore that carries considerable zinc. In order to reach these ore bodies a vertical shaft was begun in 1918. Early in 1920 the water level was reached at a depth of 496 feet and pumping equipment was installed.

Meanwhile the bedded ores above the water level were energetically mined. Most of the ore came from the so-called Big bed and the Twenty-foot bed. In order to obtain all of the ore in the much faulted central section of the ore body, where it was difficult to sustain the roof, the overburden was removed and two large glory holes were made. By the beginning of 1920 these ore beds had been largely exhausted, and the bulk of the output in 1920 came from the Davidson ore body, which had been taken over in July, 1918, and principally from a big stope that was 1,000 feet from the hoisting shaft. Mules were used for tramming.

Dividends of $\$ 124,924$ were paid in $1915, \$ 250,000$ in 1916 , and $\$ 200,000$ in 1917. It was during these years that the mine was the leading producer of lead in the State. At the end of 1920 the company was not strong enough financially to continue development, and, consequently, as the stock was nonassessable and there was no money in the treasury the company increased its share capital and sold 440,000 additional shares of stock to its stockholders. By September 1, 1921, the company was again in financial difficulties and again increased its share capital, at the same time authorizing a $\$ 300,000$ bond issue. In December, 1922, the vertical shaft had attained a depth of 850 feet and some drifting had been done on the 835-foot level, but not enough to reach the silver-zinc-lead ore bed that had been indicated by the drill holes. The pumping equipment was unable to handle the large flow of water, 350 gallons a minute, and all work was sus- pended in 1923. A special stockholders' meeting on August 22, 1923, authorized the appointment of a reorganization committee and a new company, the Prince Consolidated Mining Co., was organized.

The Virginia Louise mine had been active during 1919, 1920, and 1921 but was shut down in 1922. Early in 1923 it was leased to a new concern, the Virginia Louise Development Co., which began very active mining. In 1924 the owners of the Virginia Louise Development Co. acquired control of the new Prince Consolidated Mining Co. As by this time the Virginia Louise mine had been nearly worked out above water level, elaborate preparations were made to unwater both mines. The workings on the 835-foot level of the Prince mine were extended, and the Sulphide ore body and the Silver bed, as they are called, were developed. A flotation plant with a daily capacity of 250 tons and a power plant costing $\$ 300$,000 were projected. In March, 1926, pumping ceased pending the raising of the necessary capital to build the flotation and power plants. Mining of the manganiferous flux continued on a very reduced scale during the early part of 1926 and finally ceased, as the demand for flux of that kind by the Utah smelters had fallen off, because of the abundant supply of pyrite as a by-product from the flotation treatment of mixed sulphide ores.

\section{DEVELOPMENT}

The Prince mine was originally developed by a $65^{\circ}$ incline, 550 feet long, from which six levels were driven. The present working shaft is a 2-compartment vertical shaft, 850 feet deep. From it five levels have been driven, at vertical depths of $168,245,343,477$, and 835 feet, and the drifts aggregate several miles in length.

The Virginia Louise mine was worked through a vertical 2-compartment shaft 475 feet deep, from which five levels extend. The fifth or bottom level is 450 feet below the collar. From it an incline sloping $17^{\circ}$ was sunk and a sublevel was driven.

The Prince and Virginia Louise workings are connected on only one level. The third level of the Prince connects with the second level (vertical depth 268 feet) of the Virginia Louise.

\section{GENERAL GEOLOGIC FEATURES}

The formations exposed in the immediate vicinity of the principal shafts are the Lyndon limestone at the Prince mine and the Highland Peak limestone at the Virginia Louise mine. The Chisholm shale and the Pioche shale also occur near by. The distribution of these formations in the area surrounding the mines is shown in Figure 12. 


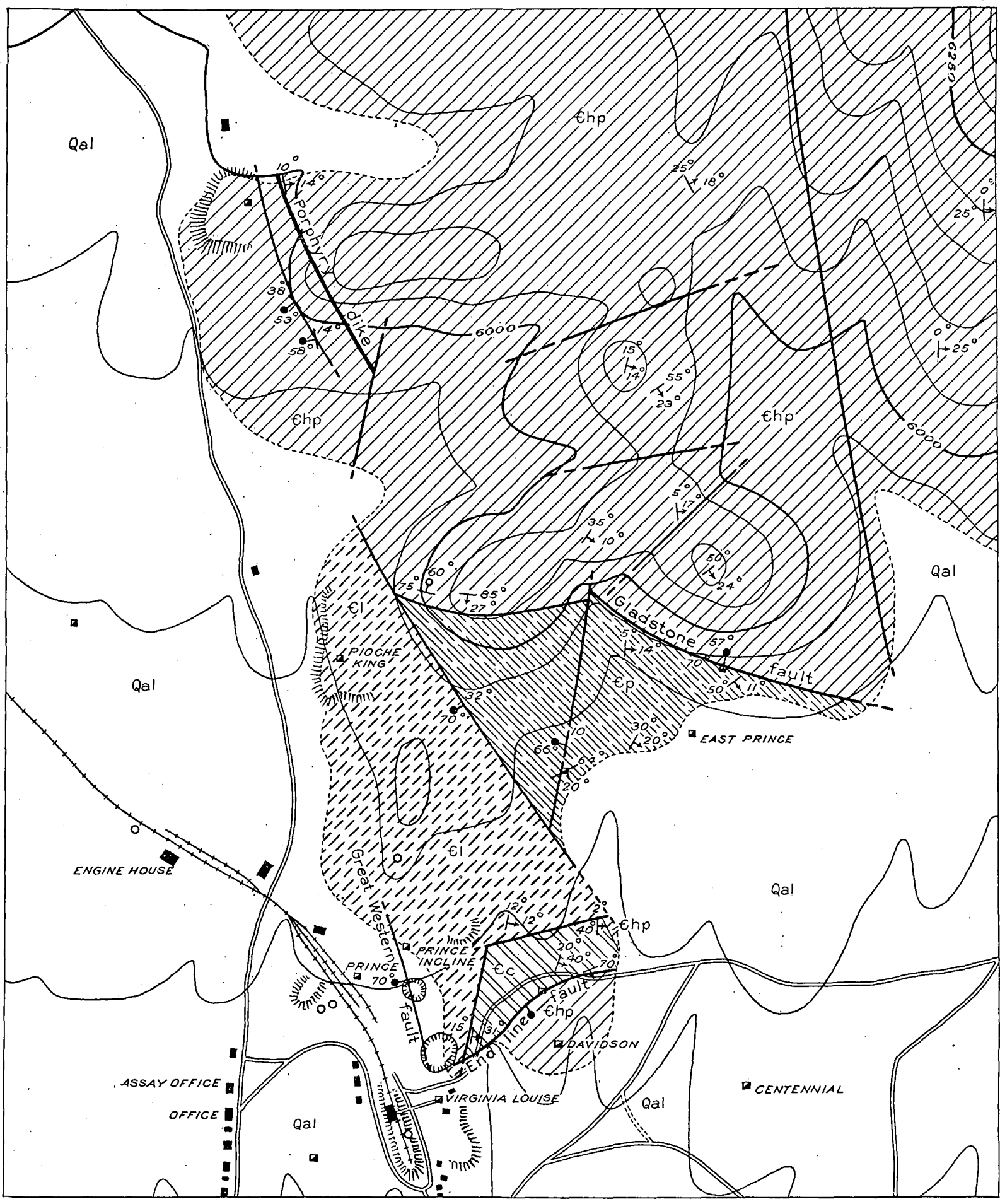

EXPLANATION

QUATERNARY
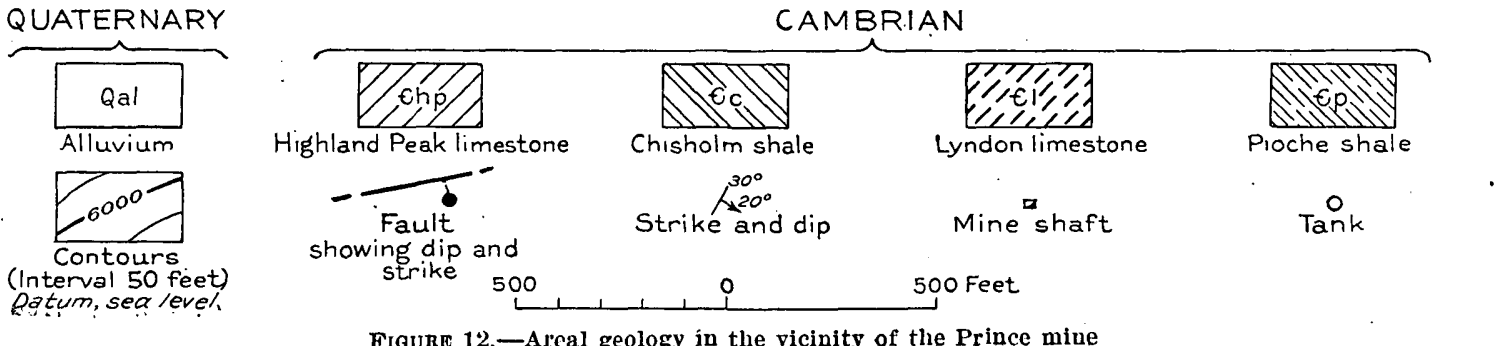
The rocks as a rule dip at low angles. Faults are n!umerous and are of practical consequence. The End Line fault, so termed because it corresponds approximately in position with the end line separating the Prince ground from the Virginia Louise, separates the Lyndon limestone in the ore zone from the Highland Peak limestone. North of the fault, in the Prince ground, the strata dip $5^{\circ}-20^{\circ} \mathrm{E}$; ; south of the fault they dip much more steeply, as much as $45^{\circ}$. The Great Western fault is prominently shown in the glory holes; it trends N. $18^{\circ} \mathrm{W}$. and dips $65^{\circ}-70^{\circ} \mathrm{W}$. It can be traced a short distance north of the Prince incline but not much farther, although exposures of bedrock are excellent. The vertical displacement on this normal fault is not accurately known, but it is certainly less than 400 feet (the thickness of the Lyndon limestone) and appears to be 200 or 300 feet. In general it marks the westward limit of manganiferous ore on the surface, except north of the Prince incline, where manganiferous ore borders the west side of: the fault. Underground many other faults have been found, which break the continuity of the ore bodies.

\section{geNERAL FEATURES OF THE ORE BODIES}

The ore zone is 1,500 feet long and 500 feet wide in its widest portion, although no one of the ore beds was workable or was continuous over these maximum limits. The ore zone trends N. $20^{\circ} \mathrm{W}$.

The ore bodies above the water level consist of five beds of soft black oxidized material, which grades into material that is nearly similar in appearance but is too siliceous to be' a fluxing ore. The ore bodies occur successively one below another; the highestthe Davidson ore body-is at the base of the Highland Peak limestone. Between the Davidson ore body and the next ore bed below it, which is in the Lyndon limestone, there intervenes the barren Chisholm shale, and the remaining stratigraphically lower ore beds have replaced limestone beds in the underlying Pioche shale. In the bulk of the ore no silver, lead, or zinc mineral can be recognized, and the grade can be determined only by analysis. The insoluble portion, essentially silica, is a vital factor in determining the grade of the ore as a flux, as the ore is sold on the basis of the excess units of total lime; iron, and manganese over the units of insoluble matter. Residual bits of galena occur locally in the oxidized ore, and lenses of cerusite and anglesite are occasionally found. Horses of unreplaced limestone occur in the cre and are especially large in the marginal parts of the ore bodies.

Besides the beds of black oxidized ore two veins of siliceous ore occur in the Prince mine and a body of similar ore was found in the Virginia Louise mine in the large stope in the Big bed on the 500-foot level. It is considered by some that the fissures occupied by these veins were the feeding channels of the bedded ore, but the evidence is not strong. The general coincidence of the best ore with proximity to the Great Western fault and the parallelism of the ore belt and the fault suggest that this fault was the main mineralizing fissure.

\section{DETAILS OF THE ORE BEDS AND VEINS}

Davidson bed.-The Davidson bed, the uppermost of the several ore beds, occurs only south of the End Line fault, for it has been removed by erosion from the block of ground that lies north of the fault. It comprises the bottom 50 feet of the Highland Peak limestone and therefore rests directly on the Chisholm shale. Its average dip where mined is $40^{\circ}-45^{\circ} \mathrm{ESE}$. Its position was such that this dip brought the bed against the End Line fault, which limited the ore approximately on the 300 -foot level, and consequently the Davidson bed was mined only on the upper levels of the two mines. The hanging wall of the ore bed is a limestone that was not acted upon by the oreforming solutions and remained unmineralized.

The ore in the Davidson bed was the most desirable bedded ore in the two mines, as it was lower in silica and carried a proportionately greater excess of iron and manganese oxides. Averiages of samples taken by W. H. Weed on the 200-foot level of the Virginia Louise mine gave the following contents:

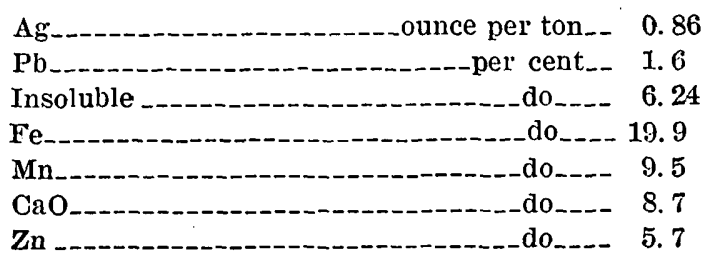

Big bed.-The Big bed is the mineralized portion of the upper part of the Lyndon limestone-that portion which immediately underlies the Chisholm shale. Its thickness shows a wide range, and an average is difficult to give. The hanging wall is usually the Chisholm shale. The ore body has no definite footwall, as the portion of the Lyndon limestone that underlies the minable ore was mineralized to material much like the ore and differs from the ore only in containing more insoluble matter than the maximum that is profitable to mine. The boundary separating the ore from this lower siliceous material is not sharp nor readily recognized.

In the portion of the ore body in the Prince mine the Big bed was much faulted and was therefore found on several levels. Some of the ore occurred on the first level and was called the "100-level bed." The main portion of the Big bed accurred through 
the central part of the Prince mine and was worked from the 200-foot level. In the southern part of the Prince mine a large stope 70 to 80 feet high was opened above and below the 400-foot level: The main production of the Prince mine from 1915 to 1918 came from the Big bed.

In the Virginia Louise mine the Big bed was found on the 200-foot and 300-foot levels; on the 300-foot level a large body of ore was mined out from a stope 75 feet southeast of the shaft. South of this body of ore the Big bed was only very slightly mineralized, and no other ore was found on that level. From the 400-foot level a large mass of good.ore in the Big bed was worked down to the water level below the 500-foot level. In this part of the mine the bed dips steeply south. From this body came the principal output of the Virginia Louise mine during the years 1921-1924. The Big bed carried more insoluble matter than the Davidson bed, and hence the ore did not bring so high a return per ton. The ore on the lower levels of the Virginia Louise mine, however, was lower in insoluble matter and carried more silver, some carrying as high as 6 ounces to the ton. Average samples of the Big bed on the 300-foot level of the Virginia Louise mine taken by Weed show the following contents:

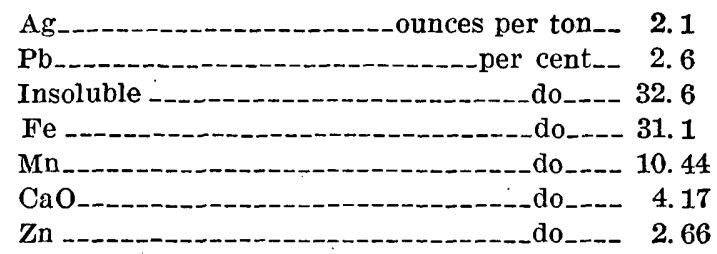

On the 400-foot level Weed found:

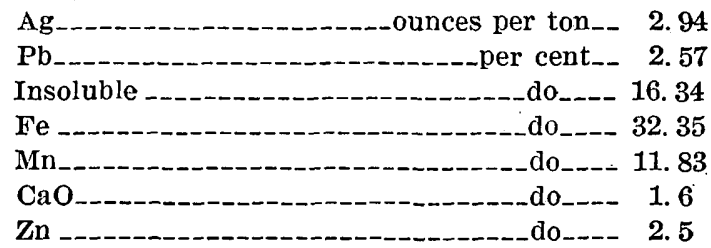

Twenty-foot bed.-The Twenty-foot bed is near the top of the Pioche shale and is separated from the Big bed by a variable thickness of mineralized Lyndon limestone too siliceous to mine and the uppermost part of the Pioche shale.

In the Prince mine the Twenty-foot bed was found on several levels, owing to its faulted condition. It was mined on the 200 and 300 foot levels in the center of the mine, but in the southern and western parts of the mine it occurred at great depths and was worked on the 400 and 500 foot levels. It was mined on the 400 -foot level in a block of ground that extended farther northeast than any other ore bed. The Twentyfoot ore bed is overlain by shale and underlain by a thick bed of micaceous sandstone or quartzite, as is well shown west of the shaft at the station of the 200foot level. It has been mined for a length of 1,500 feet, with a maximum width of 400 feet and an average thickness of 14 feet. The upward extension of the ore is limited by a fault called on the company's map the Great Western. This bed yielded the best grade of manganiferous iron flux ore that was found in the Prince mine. Pillars of leaner material have been left to support the hanging wall of the ore body, and such leaner material shows a coarse luster mottling, which is produced by innumerable oxide inclusions that interrupt the rhombohedral cleavage surfaces of the coarse blackish calcite in which they are inclosed.

Five-foot bed.-The Five-foot bed represents a limestone layer in the Pioche shale about 150 feet below the top of that formation. It is underlain by a layer of quartzitic sandstone. It occurs in the Prince mine north of the inclined shaft on the fourth level, where it was stoped to a moderate extent. The ore carries as high as 6 per cent of lead and 8 ounces of silver and $\$ 1$ in gold to the ton.

Fourteen-foot bed.-The Fourteen-foot bed (also called the Twelve-foot bed) is another bed of manganiferous flux in the Pioche shale and is about 100 feet below the Five-foot bed. It is underlain by shale, instead of massive quartzite, and is thus readily distinguishable from the Twenty-foot bed, an important matter in such highly faulted territory. It occurs in the Prince mine north of the vertical shaft on the 300-foot level. It is considered a poor bed; locally the bottom portion is richer, as shown by the fact that lessees have stoped out the basal 2 feet.

Silver, Sulphide, and Zinc beds.-By diamond drilling a bedded sulphide ore body was found below the Iowest oxide bed. The vertical shaft was deepened and the ore body was explored by means of the 835 foot level. It is reported that the ore replaces a limestone member in the Pioche shale "about 42 feet thick." The upper 12 feet has been oxidized, although submerged more than 300 feet below water level, and as silver is the main valuable constituent this portion of the ore body is called the Silver bed. The lower 30 feet is unoxidized, and this part of the ore body is lnnown as the Sulphide bed. It is estimated by the company that 235,000 tons of ore carrying 5 ounces of silver to the ton, 4 per cent of lead, and 12 per cent of zinc is indicated by the work so far done.

At the time of examination in 1926 the workings on the 835 -foot level were under water. There is little doubt that the ore body here disclosed (the Silver bed plus the Sulphide bed) corresponds to the Combined Metals ore bed, for the two agree in stratigraphic position within the Pioche shale and they are of the same thickness. The ore consists of pyrite, sphalerite, and galena, named in the order of decreas- 
ing abundance, and contains a white carbonate with curved cleavage surfaces, which the chemical analysis given on page 48 shows to be a magnesian manganosiderite containing nearly as much manganese as iron.

By deeper diamond drilling another ore bed is indicated as occurring about 250 feet below the Sulphide bed. It is 8 feet thick and carries 11 per cent of zinc and traces of silver and lead; hence it is known as the Zinc bed. Below the Zinc bed 10 feet of shale was drilled through and then the Prospect Mountain quartzite was reached, as shown by the diamond-drill cores of white vitreous quartzite, and was penetrated for 36 feet.

Fissure veins.-Two fissure veins containing siliceous ore have been found underground in the Prince mine. They are known as No. 1 and No. 2 fissures. They occur in the Lyndon limestone below the Big bed, but when traced up into the Big bed their identity becomes lost. Downward they extend into the Pioche shale, and most of the workings on them are in that formation. The two veins are roughly parallel, stand nearly vertical, and trend on the average $N .25^{\circ} \mathrm{W}$. On the third level they come within 30 feet of each other. No. 1 fissure or vein, which is from 1 to 5 feet thick between walls, has been traced for a horizontal distance of nearly 600 feet. Its northeast or hangingwall side has been dropped only 2 or 3 feet; consequently the vein does not lie along a notable fault. The ore in No. 1 vein is completely oxidized, whereas that in No. 2 vein on and below the 300-foot level carries some sulphide ore. No. 2 vein has been traced for a vertical distance of 232 feet. It dips $80^{\circ}-85^{\circ} \mathrm{E}$. and has been opened for a horizontal distance of 400 feet. Like No. 1 it occupies a fissure formed by a normal fault. The displacement along the fissure was inconsiderable, however, for the fissure has faulted the Fourteen-foot bed only 5 feet, as measured by the dip slip.

The ore in the fissure veins is erratic in distribution. In places it occupies the whole vein, elsewhere it is limited to one or the other wall, and in still other places it occurs only in the center of the vein. The sulphide ore in No. 2 vein carries between 10 and 25 per cent of lead, and the better ore carries 35 ounces of silver and $\$ 2.50$ in gold to the ton. Another small fissure vein was found on the 300 -foot level of the Prince mine. It contained oxidized ore of low grade.

The deepest workings on the fissure veins are on the fourth level (vertical depth 476 feet). Here vein No. 2 has been drifted on for 300 feet; its course is N. $45^{\circ} \mathrm{W}$.-considerably more westerly than on the upper levels. It consists of 2.5 feet of red oxidized material; the gangue contains a little quartz, but is mainly altered shale. The metal content is spotty; in places, according to report, it runs as high as 100 onces of silver to the ton.
'The fissure veins have not yet been prospected on the 835-foot level. It would be interesting to see how they behave in the underlying Prospect Mountain quartzite below the Pioche shale, which as a rule has been unfavorable to the formation of veins within it.

In the Virginia Louise mine no distinct fissure veins were ever found. However, a mass of siliceous ore stoped in the Big bed at the top of the incline on the 500 -foot level assayed 89 ounces of silver and $\$ 8$ in gold to the ton and 23 per cent of lead and certainly represented fissure ore.

MINERAL COMPOSITION OF THE OXIDIZIDD BEDDED ORES

$$
\text { By J. L. GrLLson }
$$

'The earthy black oxidized material that makes the bulk of the bedded ore is an aggregate of minerals difficult to identify owing to the fineness of the individual grains. Such ores were studied in two waysfirst, by studying polished sections of the material that had been previously cooked in Canada balsam and bakelite to prevent crumbling; second, by grinding the rock to powder, separating the constituents in heavy solutions, and examining with the petrographic microscope the fractions so separated.

The several beds of oxidized ore are so similar in mineralogy that no separate discussion of the individual beds is thought necessary. The Davidson bed is lower in quartz than the others, possibly because it is the highest bed in the sedimentary series and was consequently less affected by silicification.

The principal minerals of the oxidized bedded ore in the Prince and Virginia Louise mines are goethite, limonite, hematite, braunite, pyrolusite, quartz, several carbonates of the alkaline earths, cerusite, calamine, and plumbojarosite. Certain other minerals occur locally or are disseminated in the ore in small quantities. Vanadinite, pyromorphite, and phosgenite were found on a few specimens. A mineral analysis of the rarer constituents in the ore disclosed several minerals, the presence of which is only of scientific interest. Two that were identified are apatite and amphibole. They make less than 0.5 per cent of the ore.

The more abundant of these minerals are considered individually below in the order of the time of their formation so far as this is known.

In the oxidized ore hematite forms crystalline masses that are pseudomorphs after pyrite. The hematite was the first mineral to form by the process of oxidation. In some ore its general dissemination gives the black ore a reddish tint.

Goethite is the crystalline form of limonite and is probably the principal form in which the hydrated iron oxide occurs in the mines. As small grains of goethite can be distinguished from limonite only by optical examination, it is not feasible to differentiate the two minerals quantitatively. Together they form the most abundant minerals in the ore. They are invariably soft and crumbly, never hard, and in solid masses. 
Braunite (a manganese silicate) appears to be the most abundant manganese mineral. It is disseminated in such minute form that it can be shown to be present only by the use of high magnification.

Pyrolusite occurs in nearly all of the ore examined. The grains are usually so small that they can be distinguished only with the microscope. Examination of fragments of the powdered rock under the petrographic microscope reveals very minute needles of a mineral that are so nearly opaque that the only light visibly transmitted through them is that of the so-called Becke line. These needles are pyrolusite. In polished sections of the ore examined with the reflecting microscope aggregates of grains of pyrolusite were recognized in some specimens with high magnification. The softness of the mineral hindered its recognition in polished sections, as minute grains were difficult to polish when surrounded by hard minerals.

No other manganese mineral was identified. The grains of all the minerals are so small that the criteria for distinguishing them are but few. Manganite grains when examined by the petrographic microscope are perceptibly transparent and have a high index of refraction. Grains of psilomelane are about as opaque as the pyrolusite, but their index of refraction is lower than 1.73. No grains of manganite or psilomelane were found, although many samples of the powdered ore immersed in a liquid of the index 1.73 were examined with the petrographic microscope.

Quartz is present in all the bedded ore to a greater or less amount. Three generations occur. The first was formed by the ascending solutions that brought in the primary ore, the second was caused by precipitation from surface waters that had leached the silica from overlying beds exposed to weathering, and the third is represented by a superficial drusy coating along seams that had formed at a late time by surface waters. The hypogene quartz is characterized by containing minute inclusions of high-index minerals, among which apatite is the only one that can be readily recognized. The second generation can be distinguished with certainty from the first, however, only when quartz is found inside of pseudomorphs of hematite after pyrite: Ore in which the second generation of quartz is abundant is usually reddish from included hematite, and this color and the fine grain of the quartz give it the appearance of jasper.

Carbonate minerals form at least three generations in the bedded ore. ${ }^{40}$ The most conspicuous example of these minerals in these two mines, as in other mines in the Pioche district, is a coarsely crystalline white "spar" that occurs both in the ore and in the unoxidized country rock surrounding the ore bodies. This spar is a hypogene mineral (see $\mathrm{p}$. 49 ), as it occurs in unoxidized ore and is commonly replaced by the products of oxidation. It is shown by chemical analysis and by optical examination to be nearly pure calcite. An analysis of a spar of this kind from the Virginia Louise mine is given on page 50 .

Dolomite and another generation of calcite are two very late minerals that were formed during the oxidation of the ore. The dolomite occurs as white drusy aggregates along seams. These are coated by later and larger calcite crystals of a flat or tabular habit.

Cerusite is probably the principal oxidized iead mineral, although its presence could not always be proved in the crumbly ore known to carry 2 to 4 per cent of lead. In a few places in the Prince mine masses of oxidized ore were

"At the time of examination by Mr. Gillson the occurrence of the genetically important carbonate, the manganosiderite described on $\mathbf{p}$. 48 , appears not to have been known.-A. K. found that were richer in lead and lower in manganese. Such material consisted chiefly of hematite, quartz, and cerusite.

Calamine is probably the principal zinc mineral and was readily identified, but like the cerusite it could not always be found in the finely crystalline black crumbly ore, although analyses of such ore have shown a zinc content of as much as 5 per cent. Two 20-gram samples of this kind of ore-one from the Davidson bed and one from the Big bed-were ground and sized, and the powder was floated in Clerici's solutions adjusted to a density to float calamine, but not a single grain of calamine was collected. The calamine, if present, must therefore be in a very finely divided form. The zinc may occur, however, as smithsonite and hydrozincite.

Plumbojarosite was found in many of the specimens of oxidized siliceous ore. In the earthy fluxing ore it was not found but is very probably present.

- Vanadinite and pyromorphite occur as crystalline druses along seams in the oxidized ore. The minerals may be disseminated through the ore but were not observed there.

Apatite and an amphibole were recognized by optical methods in the powder of oxidized ore. Repeated tests were made to insure that the grains so found had not come into the powder through accidental contamination in the laboratory. In age these minerals probably belong with the primary quartz and with the sulphides that have been destroyed by oxidation.

Silver is very low in the oxidized bedded ore, and the silver mineral or minerals have not been identified. The silver is probably present as the chloride.

Gold is known only from assays. It probably is present in the native state.

\section{MINERALOGY OF THE FISSURE ORE}

As the good ore in the fissures was largely mined out by 1923 , the unoxidized fissure ore of the mines could not be studied in place. Specimens of such ore were supplied by officials of the company. Oxidized fissure ore was seen underground. A small fissure on the 300-foot level of the Prince mine consists of leached silicified limestone with cavernous quartz, in the cavities of which plumbojarosite occurs. The ore in No. 2 fissure was seen on the 250 -foot level and is a soft reddish material consisting of quartz, sericite, hematite, cerusite, and plumbojarosite.

Specimens of unoxidized fissure ore supplied by the company consist of banded quartz with a moderate amount of sericite. Pyrite, a black variety of sphalerite, and galena are the most abundant metallic minerals. Arsenopyrite occurs but is more rare. Several other metallic minerals occur, but the grains are too small to be distinguished without the microscope. They occur as a rule as minute blebs in the galena, and the grains are so small that their positive identification is difficult.

The minerals in the fissure ore above described are all primary or hypogene minerals, formed by hot ascending solutions. Other minerals that are the result of surface oxidation and downward sulphide enrichment occur in some or all of this ore. They are 
pearceite, anglesite, quartz, cerusite, covellite, chalcocite, hematite, jarosite, several manganese minerals, pyromorphite, and vanadinite. Among these minerals the pearceite and the oxidized lead minerals are the only ones of economic value. The pearceite represents enrichment by silver, and ore containing it assays from 80 to 100 ounces of silver to the ton. The pearceite replaced the galena along the margins and in cleavage cracks. It is nowhere found in disconnected blebs distributed throughout the galena like the pyrargyrite and associated minerals.

\section{HALF MOON AND ABE IINCOLN MINES}

The Half Moon and Abe Lincoln mines are 11/2 miles west of Pioche, on the west side of the Ely Range. The property consists of 42 claims aggregating about 600 acres; 29 claims are patented. The company owns 125 acres outright, and the remainder is held under options.

Ore was found here in the late sixties. About 1880 ore was hauled to Milford, Utah. It is reported that 23,758 tons of ore carrying $\$ 9$ in gold and 18 ounces of silver to the ton and 17 per cent of lead has been shipped, but this ore obviously was sorted before it was shipped.

The ore body, a flat-lying bed vein, is opened by adit tunnels. One group of workings on the vein is known as the Half Moon, and the other, which opens on the next gulch south, as the Abe Lincoln. The area stoped is reported to measure 1,000 by 300 feet.

The vein is in the Chisholm shale at the contact of the shale and a 3-foot bed of limestone that occurs 20 feet below the top of the Chisholm. It is parallel to the bedding, and the limestone bed forms its hanging wall. The vein dips at a gentle angle in the Half Moon workings and is nearly flat in the Abe Lincoln. It is cut off on the east by a fault trending N. $30^{\circ} \mathrm{W}$. and dipping $65^{\circ} \mathrm{E}$.; along the fault is a gouge of shale 5 feet thick. As the Highland Peak limestone makes the hangin' wall of the fault and the relatively downthrown block is thus on the east side, the fault is a normal fault. It is regarded by some as having been the mineralizing fissure up which the ore-forming solutions ascended, but there is no conclusive evidence to prove this; it is certain that there has been strong postmineral movement along the fault. This fault is itself cut by a northeastward-trending fault which has dropped the Half Moon portion of the vein relatively to the Abe Lincoln portion.

The vein averages about a foot in thickness; in places it attains a maximum thickness of 2 feet. The gangue is a millk-white quartz, which has a welldefined banded structure. The bands are from half an inch to 3 inches thick; they have a comb structure, and the quartz crystals extend inward from the boundaries of each band to its center.
The principal sulphide is galena, which is fairly common in blebs and locally occurs in veinlets that cut across a number of the quartz bands. A little pyrite was seen, but most of it has been oxidized to limonite.

The vein because of its stratiform character has heretofore been considered to be the result of the replacement of the lower part of the limestone bed that overlies it. The coarse comby nature of the quartz, in contrast to the minutely crystalline "jasperoid" habit of quartz that has formed by the replacement of limestone, makes this idea improbable, and the presence of shale fragments in the quartz and slabs of shale locally between the bands proves it to be erroneous. The most probable explanation is that the successive bands of comby quartz were formed by the filling of cavities that were opened as a result of successive movements parallel to the bedding.

\section{FAIRVIEW MINE}

The Fairview or Nevada Lead mine is 25 miles northwest of Pioche, a short distance west of the ElyPioche road. The vein was discovered 50 years ago, but until 1922 nothing but assessment work was done. Since then it has been developed by D. C. Robinson under a lease and option from the Ellis estate, of Salt Lake City.

The mine is opened by an incline averaging $52^{\circ} \mathrm{E}$. Levels have been driven at 193 and 420 feet, and the incline was being deepened in 1926 . The equipment includes a 10-horsepower hoist and a 30-horsepower semi-Diesel engine to operate a compressor.

The country rock comprises Devonian limestone and quartzite, the limestone predominating; it strikes north and dips $25^{\circ} \mathrm{W}$. The vein strikes north and dips eastward slightly more steeply than the slope of the incline, which at the surface was sunk on it. The vein, which is highly quartzose, is reported to have carried 20 per cent of lead through a thickness of 14 feet. In the deeper workings the vein so far as yet disclosed is lean.

\section{BRISTOL SILVER MINES CO.}

GENERAL FEATURES

The claims of the Bristol Silver Mines Co., covering 324 acres of patented land; are chiefly on the west slope of the Bristol Range, 16 miles north of Pioche. They are 25 miles by road from Pioche, as the road in order to reach the west side of the range crosses through Bristol Pass, at the north end of the range. The camp and main workings are at an altitude of 7,250 feet. The mine is connected by an aerial tram 2 miles long with the terminus of the Pioche Pacific Railroad at Jackrabbit, on the east side of the range. Over this tram are brought the mine supplies and the water necessary for domestic use and for the compressor 
plant. A transmission line supplies electricity from the power plant at Jackrabbit.

The chief mines are the May Day, Gypsy, Hillside, Tempest, and Iron. The May Day and Gypsy mines are connected; and their deeper workings are generally known as the Bristol mine. The ore deposits were discovered in the late sixties, and they supplied ore to the smelter that was built in the seventies at Bristol Well, 5 miles west of the camp. Ore has been mined more or less continuously since the early days. ${ }^{41}$ In the course of time consolidations have been effected, and most of the more productive mines are now owned or controlled by the Bristol Silver Mines Co., incorporated in 1919 in Nevada. Through ownership of a major part of the issued stock the company controls the Black Metal Mines (Inc.), whose ground adjoins the Bristol property on the east and extends down the east slope of the Bristol Range to Jackrabbit. The recent installation of the power plant at Jackrabbit and of new machinery at the Bristol mine has greatly improved operating conditions.

The Bristol mine is worked through the Snyder shaft, an incline sloping $69^{\circ} \mathrm{S}$. Ore was being extracted during 1926 chiefly from the 950 and 1,050 foot sublevels. The shaft was being deepened and had attained a depth of 1,300 feet. In addition to the work being done by the company itself a lessee was crosscutting from the May Day tunnel to intersect the Tempest fissure at a point below the workings of the Inman mine.

The monthly output was increased from 343 tons in January, 1926, to 800 tons in July. The value of the ore fluctuated between $\$ 10$ and $\$ 16$ a ton in silver, copper, lead, and zinc. Average figures of composition are of little significance, as the proportion of metals fluctuates widely according to what veins are supplying the ore.

The total output to 1926 is reported to be $\$ 3,000,000$. Of this, the Hillside mine is said to have produced $\$ 2,000,000$, and the May Day and Gypsy most of the remainder. The Tempest, Vesuvius, National, and Great Eastern have not produced much ore.

The May Day vein was opened by an incline 500 feet long, sloping $40^{\circ} \mathrm{SE}$. The bottom or 500-foot level of the May Day mine corresponds to the 200foot level of the Gypsy mine. The Gypsy vein was developed by a vertical shaft 600 feet deep. The Gypsy and May Day workings are now. abandoned, except that some exploratory work is being done on the May Day tunnel, or 100-foot level. The total

$\$ 1$ Hill, J. M., Notes on some mining districts in eastern Nevada: U. S. Geol. Survey Bull. 648, pp. 127-128, 1916. workings on the May Day and Gypsy veins exceed 2 miles of drifts, crosscuts, and raises. (See pl. 8.)

\section{AREAL GEOLOGY}

The rocks in the vicinity of the May Day and Gypsy workings consist of limestones of the Highland Peak formation. They strike east and dip on the average $20^{\circ} \mathrm{N}$. Two key beds, 150 feet stratigraphically apart, are easily distinguishable and serve as valuable guides to determine the displacement on the faults that have dislocated the strata. The lower of these key beds, which is readily found at the Snyder shaft, is a cherty layer 3 feet thick and contains peculiar concentric thinly banded structures, nany of which have been partly or wholly replaced by chert. The upper key bed consists of 6 inches of conglomerate (?), probably an edgewise conglomerate, and a few feet of cherty limestone, in which the chert occurs as more or less discontinuous layers.

The exact stratigraphic position of the collar of the Snyder shaft is a matter of considerable practical importance, as the shaft is being deepened in order to intersect the favorable limestones in the underlying Pioche shale. When the bottom of the Highland Peak limestone is reached-it had not been reached at 1,300 feet, and its position can not be accurately predictedthere remain 150 feet of Chisholm shale and 400 feet of: Lyndon limestone to be penetrated before the top of the Pioche shale will be cut.

The limestones are cut by numerous steep faults, prevailingly of north-south strike. The vertical displacement of these faults ranges from less than a foot in the smallest to 90 feet in the fault that is well exposed 400 feet east of the Snyder shaft. The fault fissures range from tight fractures to breccia zones several feet thick. The extent and intensity of brecciation, as measured by the degree to which the limestone was crushed to a breccia composed of small-sized fragments, were evidently, as will be shown later, important factors in determining the position of shoots of ore.

At the base of the range west of the Bristol mine Devonian rocks have been thrust over the older Paleozoic rocks (Mendha limestone and Ordovician limestone). The Ordovician limestone includes some shaly beds, which before this survey were thought to be part of the Pioche shale but which are now known from the fossils that have been found in them to be of Ordovician age. All these rocks, including the overthrust Devonian beds, are separated from the Highland Peak limestone at the mine by a normal fault, which has dropped them. 


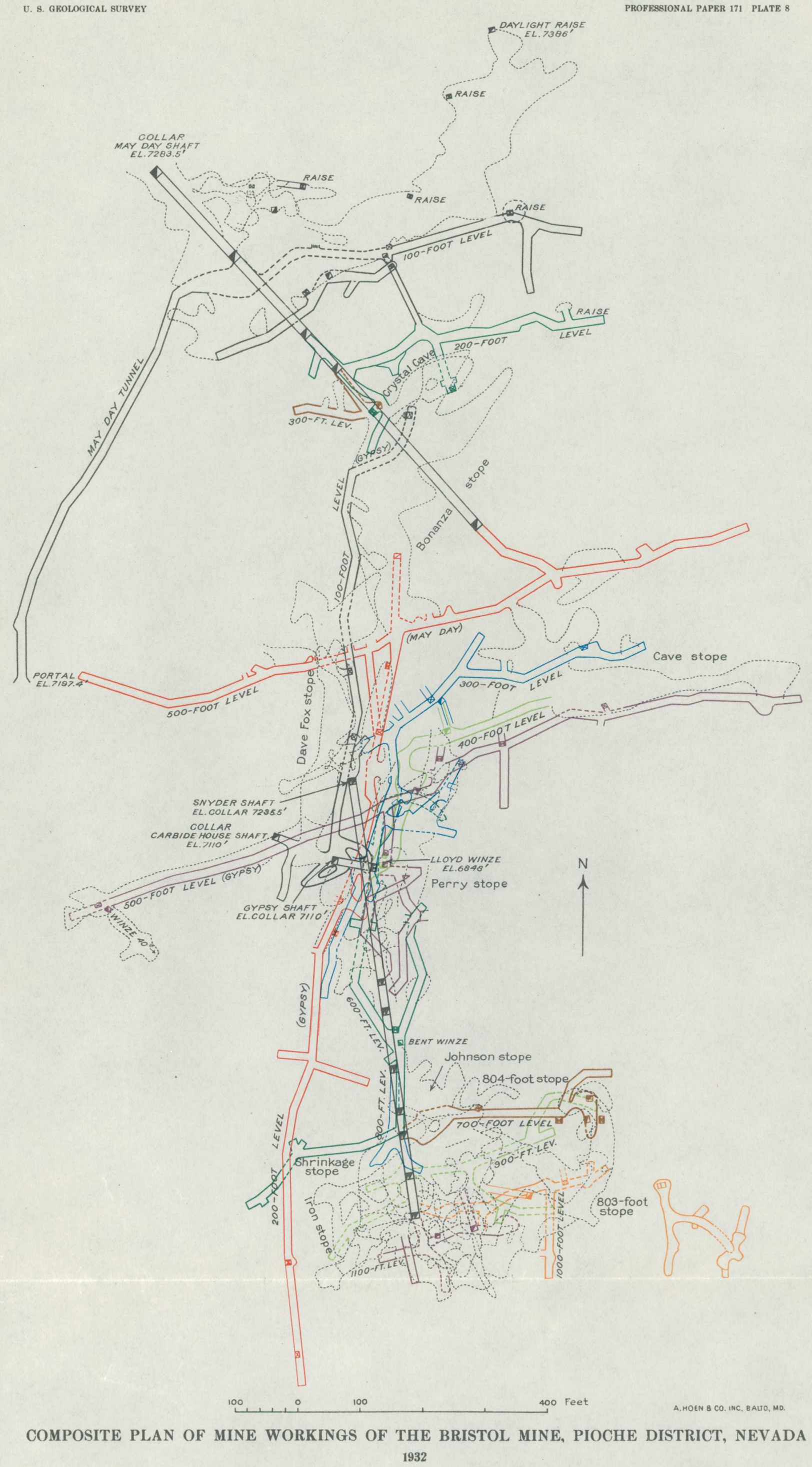


ORE BODIES OF THE BRISTOL MINE GENERAL CHARACTER

The ore bodies were formed by the replacement of limestone and brecciated limestone in or adjacent to fissures. The ore bodies that were mined in the May Day and Gypsy mines and are now being mined in the deeper workings through the Snyder shaft constitute an evidently related system, the relationship being determined in part by intersecting or contemporaneous fissures. At the mine several series of fissures are recognized-the May. Day, striking N. $80^{\circ} \mathrm{E}$. and dipping $45^{\circ} \mathrm{S}$; ; the Tempest, striking N. $80^{\circ} \mathrm{E}$. and dipping $70^{\circ}-80^{\circ} \mathrm{S}$; ; the Gypsy-National, striking north to N. $25^{\circ}$ E. and dipping $70^{\circ}-80^{\circ}$ E.; and the Lead-Zinc, striking north to N. $20^{\circ} \mathrm{W}$. and dipping from vertical to $85^{\circ} \mathrm{E}$. or $\mathrm{W}$. These series of veins are thought to be characterized by containing ores of different kinds. "Mixed ores" occur at intersections or junctions. The different ores are believed to have been formed during different epochs of mineralization, but the evidence available in 1926 was not absolutely conclusive, for the ores are all thoroughly oxidized, and there was bound to be some rearrangement of the copper, zinc, and iron during the time the primary (sulphide) ore was being oxidized. This redistribution is most plainly shown by the tendency of the copper to occur in the form of chrysocolla and copper pitch in the footwall portions of the ore bodies. The general limestone environment of the ore bodies would prevent, however, any long-distance migration of the metals during oxidation.

\section{MAY DAY VEIN}

The general features of the May Day vein are well shown at the discovery outcrop. The vein here strikes N. $70^{\circ}$ E. and dips $45^{\circ}$ S. Both hanging-wall and footwall rocks are massive fine-grained (aphanitic) limestones. In the footwall is a fault trending N. $70^{\circ}$ E. and dipping $55^{\circ} \mathrm{S}$.; the fault zone contains 4 feet of brecciated limestone under a well-defined hanging wall. It appears to be a fault of some magnitude, as the two key beds can not be traced across it; but it has no known bearing on the occurrence of the ore bodies.

At the outcrop the May Day ore body was about 40 feet long and 6 feet in greatest thickness, tapering abruptly at both ends along the strike. The ore was thoroughly oxidized; jarosite is visible, and more or less chrysocolla occurs in films and veinlets in the footwall. The outcrop proved to be the top of a large irregular ore body; it was opened by the May Day incline, which was sunk on the dip of the vein.

The tunnel level, which cuts the vein 86 feet below the outcrop, is particularly instructive. The ore shoot, which has here lengthened to 250 feet and thickened to a maximum of 30 feet, is clearly the result of the replacement of a breccia, for in places angular blocks as much as 2 feet in diameter are sharply outlined by the oxidized ore that surrounds them. The May Day fissure has been followed by a cirift (not shown in pl. 8) for 600 feet east of this great shoot of ore in the hope of finding another shoot, and in most of this distance it is not thicker than a knife blade.

On the 300-foot level of the May Day shaft the May Day shoot lies just east of the junction or intersection of the vein with the Gypsy vein; it has formed as the result of the replacement of a brecciated massive limestone.

The May Day vein intersects or joins a steep vein of the Tempest series below the 700-foot level of the Snyder shaft, and the ore has continued downward along this steep vein. It was held by some that the Tempest fracture had faulted the May Day vein, dropping it 200 feet, but the failure of the Tempest vein to displace the key beds on the surface definitely disproves this idea. A huge shrinkage stope was extracted on the 800-foot level of the Snyder shaft, from which $\$ 600,000$ in ore was taken out. Notable is the abrupt way in which the ore body ends on the east; 5 feet beyond the margin of the ore body the Tempest fissure is only 2 inches thick and a few feet farther along it apparently dies out. The factors that determined the formation of this great body of ore are enigmatic. Along the Tempest fissure on the level above this one the thick-bedded limestone that forms both the footwall and hanging-wall rock has been brecciated, and the larger fragments of the resultant breccia have remained unaltered. Around the edges of the ore body the breccia is cemented by coarse carbonate spar, and the limestone fragments inclosed in this cement are partly recrystallized. If the volume of brecciation and the degree to which the limestone was reduced to an angular rubble were the controlling factors that determined the position of a great ore shoot in the Bristol mine, then the cause for the abrupt or localized development of the brecciation is still obscure. The occurrence of such great podlike masses of cre is a powerful incentive to explore the fissure systems thoroughly.

The ore that was being mined in 1926 on the 950 foot sublevel was a mixed ore-that is, it contained silver, copper, zinc, and lead. It was highly oxidized, but in places it contained a little galena. It was somewhat manganiferous. It showed relics of breccia structure, for angular fragments of limestone could be found in the ore. Galena-bearing ore occurred in a transverse vein at its intersection with the Tempest vein. Calamine and zinc carbonate made white coat- 
ings on the fracture surfaces of the ore. When "boulders" of limestone (unreplaced blocks of limestone) begin to appear in the face, they presage the end of the ore shoot.

Large bodies of limonitic iron oxide containing considerable jarosite occur in the Tempest vein on the $1,000,1,050$, and 1,100 foot levels. Much of the iron oxide on the 1,100-foot level has the structure of carbonate. These barren masses presented this problem to the operators: Do they represent a leached zone from which the copper and lead have been carried away? On account of the well-known immobility of lead in oxidized ores and the presence of an abundant precipitant in the form of calcite, it is improbable that the metals were carried away. The probable answer is that the iron-oxide bodies represent a zone in which the primary ore had been abnormally high in iron minerals, chiefly pyrite, and low in galena and copperbearing sulphide. Some of the iron in the oxidized mass may have come from a zone higher up, as indicated by the prevalence of jarosite.

\section{GYPSY VEIN}

The Gypsy fissure strikes north and dips $80^{\circ} \mathrm{E}$. Little or no displacement has occurred on it. On the north it ends against the May Day fissure, being either cut off by that fissure or of contemporaneous origin. According to Hill, ${ }^{42}$

from the 250-foot level to the greatest depth attained at the time of visit [1913] there was a nearly continuous shoot of ore 20 to 40 feet wide and averaging about 150 feet long which pitched $45^{\circ} \mathrm{S}$. on the vein. This ore body occurs above the May Day-Gypsy intersection and has been mined in the Perry and Green stopes and the Lloyd winze. In the stopes in this ore shoot nearly pure lead carbonate ore was found near the hanging wall and copper ores next the footwall.

The Gypsy ore shoot was probably formed by mineralizing solutions that were flowing upward along the May Day fissure and that escaped into a hanging-wall fracture (the Gypsy fissure) and there produced an ore body. The greatest lateral exploration on the Gypsy fissure was undertaken on the 200 -foot level, where the fissure was followed by a drift for 500 feet south of the ore shoot, which occurred near the intersection or junction with the May Day vein. Throughout this distance the fissure is marked by a well-defined hanging wall, but shows little or no mineralization. This drift, like the long drift on the May Day fissure on the 100-foot level, emphasizes the fact that large ore shoots may occur in this district along seemingly inconsequential fissures.

\section{NATIONAL MINE}

The National mine is 450 feet east of the Snyder shaft. The workings consist of a large open cut and a shallow winze. The mine is reported to have produced 5,000 tons of ore before 1906. Since then only one shipment has been made, in 1914, which assayed 15.9 ounces of silver and 0.025 ounce of gold to the ton and carried 6.5 per cent of lead, 10 per cent of copper, 7.3 per cent of zinc, 16.4 per cent of lime, 9.5 per cent of iron, and 9.8 per cent of insoluble matter.

The National workings are on the south side of the gulch that extends eastward from the Snyder shaft. The ore body strikes north and dips $60^{\circ} \mathrm{E}$. The wall rocks have been recrystallized to a coarse calcite that shows cleavage rhombs an inch in size. Locally the ore extends short distances out from the fissure vein into the limestones parallel to their bedding. The ore is completely oxidized, chrysocolla being the only obviously recognizable constituent, but the general character of the ore is indicated by the analysis just quoted.

\section{VESUVIUS MINE}

The Vesuvius mine is a short distance northeast of the National mine and higher on the mountain. The openings are on what are essentially bedded replacement deposits dipping $5^{\circ} \mathrm{N}$. The main ore body was about 2 feet thick; chrysocolla and malachite are now the chief metalliferous minerals to be seen. The replacement affected a group of thin beds, individually 2 inches or so thick, that are intercalated between thick beds. Coarse calcite in grains as much as 2 inches in diameter is common as the result of the recrystallization of the limestone adjacent to the ore. No work appears to have been done on the mine since it was described by Hill. ${ }^{43}$

\section{INMAN MINE}

The Inman workings are about 1,200 feet east of the Snyder shaft. The portal is at the intersection of a vein striking $\mathrm{N} .85^{\circ}$ E. and dipping $75^{\circ} \mathrm{S}$., which is regarded as being the westward extension of the Tempest vein, and a narrow vein striking N. $20^{\circ} \mathrm{E}$. and dipping $80^{\circ} \mathrm{E}$. There is another cross vein 30 feet west of the first, and still another 50 feet west of the second.

The Tempest vein, or, as it may perhaps be more safely called, the vein of the Tempest series, for the actual continuity between it and the Tempest vein has not been established, has been followed by a short tunnel. It is highly oxidized and ranges from 2 to 4 feet in thickness. Copper pitch and chrysocolla are the main metalliferous constituents of the ore. Curved calcite and jarosite are also present. The transverse veins average only a few inches in thickness, and though filled mainly with a banded radial calcite resembling aragonite they contain some chrysocolla and copper pitch.

«s Hill, J. M., op. cit., p. 132.

$\checkmark$ Bill, J. M., op. cit., p. 131. 


\section{TEMPEST MINE}

The Tempest mine is higher on the mountain than the Inman, being at an altitude of 7,850 feet. It wa: developed by an inclined shaft 300 feet long, from which four levels were turned. The vein strikes $\mathrm{N}$. $85^{\circ} \mathrm{E}$. and dips $70^{\circ} \mathrm{S}$. The ore is an oxidized silvercopper material in which chrysocolla is recognizable, especially as a lining on the footwall. Notable mineralogically is the abundance on the dump of large pieces of radially fibrous mineral, which because of its delicate tints of green and yellow suggests aragonite or smithsonite but proves to be merely calcite.

The Tempest shaft is situated at the intersection or junction of the Tempest vein with a 4-foot fracture zone trending $\mathrm{N} .20^{\circ} \mathrm{W}$. and standing about vertical. The fracture zone, which is a normal fault of 1 -foot drop, carries some chrysocolla 75 feet north of the shaft.

It is reported that the face of ore left on the 300foot level assays 40 ounces of silver to the ton and 5 per cent of copper; and under this belief a tunnel is now being driven from the May Day tunnel level to cut the downward extension of that ore.

\section{HILLSIDE MINE}

The Hillside mine is near the summit of the Bristol Range, at an altitude of 8,000 feet. It was one of the pioneer producers in the district and was worked mainly between 1870 and 1885 . It is reported to have yiclded $\$ 2,000,000$. It was developed by an incline 900 feet long, with levels at intervals of 100 feet, but is now inaccessible.

The country rock at the incline consists of limestones of the Highland Peak formation, 6 feet or more in thickness, which are sufficiently coarse grained to be called marbles. The vein strikes $\mathrm{N}$. $75^{\circ} \mathrm{E}$. and dips $70^{\circ} \mathrm{S}$. at the incline, but 150 feet below the collar it flattens to an average of $40^{\circ}$. The ore is an oxidized silver-copper ore like that of the May Day. Chrysocolla and malachite are the most conspicuous constituents.

According to Hill, ${ }^{44}$ who was able to examine the mine while it was still partly accessible,

It is said that the main ore shoot was 120 feet long and that the shaft was near the center of the shoot. Between the second and fifth levels the ore zone is said to have averaged about 16 feet wide. At a few places near the shaft between these levels pillars of ore showed two and some of them three slips cutting the ore about parallel to the footwall. At the seventh level, about 400 feet below the collar of the incline, the ore body averages about 14 feet wide. It is divided into two distinct classes of ore. Next the hanging wall a fairly continuous narrow belt of lead carbonate is separated from the lower ore body by a horse of limestone 2 to 6 feet thick. The lower ore body varies from 6 to 10

is EIII, J. M., op. cit., pp. 134-135. feet thick and consists of a mixture of limonite, copper carbonates, and copper pitch ore. This ore body continues to the eighth level and has been stoped for some distance southwest of the shaft. On the eighth level, 300 feet southwest of the shaft, the Hillside fissure is cut off by a vertical fracture that strikes N. $15^{\circ}$ E., along which there has been some mineralization. The ore body at this intersection has been stoped and it was impossible to determine the nature of the fault movement. In the copper ore body on this level some masses of sulphide have been found. A specimen of this material, said to assay 54.05 per cent copper, 72.5 ounces silver, 4 per cent lead, and 0.04 ounce gold a ton, proves to be a mixture of chalcocite, galena, and malachite. The carbonate occurs as veinlets cutting and coating the sulphide, which on first inspection seemed to be entirely chalcocite.

\section{IRON MINE}

The Iron mine is near the west base of the Bristol Range, a mile northwest of the Bristol camp. It is opened by three shafts. In 1913 about 55 tons of ore was being shipped monthly. ${ }^{45}$ During 1926 the mine was being reopened by lessees. Electric equipment was installed at the main workings, and a transmission line from the Bristol camp was built, to be paid for by the lessees by a charge of 50 cents on each ton of ore mined.

The vein occupies a fault fissure; the hanging-wall rock is Highland Peak limestone, and the footwall rock is marble. It is about 4 feet thick and dips $50^{\circ}$ $\mathrm{SE}$. at the main incline, which is reported to be 300 feet deep. High-grade silver-lead ore is said to have been obtained here. The visible material is a siliceous iron-manganese oxide in which some calamine and chrysocolla are recognizable.

\section{JACKRABBIT MINE}

The Jackrabbit mine is at the foot of the east slope of the Bristol Range. It has been known also as the Black Metals mine and as the Day mine. It is 15 miles north of Pioche, with which it is connected by a narrow-gage line, the Pioche Pacific, over which the ore from the Jackrabbit and Bristol mines is carried to the Union Pacific at Pioche. The mine is controlled by the Bristol Silver Mines Co. through ownership of a major part of the outstanding stock of the Black Metals Mines (Inc.). An aerial tram extends from the railroad terminus to the Bristol mine, on the west slope of the range. The power plant, which furnishes power to both the Jackrabbit and Bristol mines, is also located here; it is equipped with two Fairbanks-Morse Diesel engines of 240 horsepower each and supplies electricity at an operating cost of 4 cents a kilowatthour-that is, this cost omits charges of interest on investment and depreciation. The oil used (1926) was of $27^{\circ}$ Baumé gravity and cost at the plant 7 cents a gallon. 
The mine is operated through the Jackrabbit in(line, approximately 1,200 feet long. This incline trends southwest; at the surface it slopes $30^{\circ}$, but in depth it flattens to $20^{\circ}$ or less. The bottom of the incline is connected by a crosscut 2,000 feet long with the Day shaft at the 900 -foot level. The Day shaft has opened up the ehief ore bodies of the mine; it is nearly vertical and has 12 levels turned from it. A short distance below the portal of the Jackrabbit incline are the workings of the Onondaga vein. As shown by Hill's report, ${ }^{46}$ these workings had already been abandoned in 1913. The vein strikes N. $25^{\circ} \mathrm{E}$. and dips $40^{\circ} \mathrm{W}$. or less. Brecciated limestone more or less altered to a curved spar that weathers brown is the main filling. The vein was stoped in a small way cver a thickness of 1 to 3 feet, and some irregular chambers of ore in the hanging wall were mined. The ore was silver-bearing lead carbonate.

During the later part of 1926, when the Jackrabbit mine was again under operation by the company, shipments were being made at the rate of 1,900 tons of manganese ore a month.

The Jackrabbit ore body, or more accurately the Jackrabbit system of ore bodies, can best be described as consisting of a vertical pipe from which "ore beds" extend out laterally at three horizons into the gently dipping limestones that inclose the pipe. Silver-lead ore occurred in the center of the pipe, according to E. H. Snyder, and the successive companies that have worked the mine have taken out successive exterior zones, which were progressively higher in manganese and lower in silver and lead. The ore mined in 1926 was valuable only for its manganese and was shipped to the Columbia Steel Co., at Provo, Utah. It carried between 15 and 20 per cent of manganese, 3 ounces of silver to the ton, and 0.8 per cent of lead.

The Highland Peak limestone is the country rock at the mine. It strikes east and $\operatorname{dips} 15^{\circ}-35^{\circ} \mathrm{N}$. It is greatly shattered and brecciated over a large area extending from the foot of the mountain up to the upper workings. Much of the breccia is shattered white dolomite marble. The footwall of the breccia, striking N. $30^{\circ} \mathrm{W}$. and dipping $45^{\circ} \mathrm{NE}$., is shown 260 feet from the portal of the adit of the 300-foot level. Although the brecciation is impressive because of its intensity and wide extent it is without knowr bearing on the occurrence of the ore.

The ore pipe, or chimney, occurs along a vein that trends N. $25^{\circ} \mathrm{E}$., and therefore its cross section on certain levels is lens shaped rather than circular. The general features of the vein are well shown in the large pit, 100 feet long and 50 feet deep, at the entrance of the 100-foot level. The vein represents a belt of brecciated rock 25 feet thick, in which angular

${ }^{40}$ Hill, J. M., op. cit., p. 135. blocks of the limestone country rock are inclosed in coarse white spar. The vein is irregular in thickness, for it bulges out where it crosses certain beds. Extremely curved carbonate and white spar with plane cleavage are common. From this pit the adit extends along the vein S. $25^{\circ} \mathrm{W}$.; it is lined with coarse white spar as far as the old stopes, where brown curved spar appears. Some typical jasperoid occurs here also, but it was seen nowhere else in the mine.

The ore shoot has been explored down to the 1,200foot level, over a vertical range of nearly 900 feet. Below the 900 -foot level no ore was found. During 1926 the manganese ore that was being shipped to the iron smelter was being mined from the 700-foot level. Huge chambers have resulted from the removal of the ore. The ore body stands nearly vertical, and its general trend is northeast, but its boundaries are irregular in detail. Everywhere lean portions of the ore body, as shown on the walls of the chambers or in pillars left because too low in grade to mine, are seen to consist of curved spar or of very coarse white spar.

The ore consists largely of soft black oxide (wad) and pyrolusite admixed with considerable carbonate gangue; hence its low tenor of manganese. Highgrade ore is distinguished by its steely luster, which is due to the prevalence of crystallized pyrolusite in fan-shaped and radiating groups.

On the 800-foot level, just below the immense manganese stopes on the 700 -foot level, instead of large bodies of manganese ore there were only small bodies in the midst of great masses of coarse calcite showing cleavage surfaces as much as 6 inches in diameter.

The replacement bedded ore that makes off from the chimney at three horizons is known as the $\mathrm{A}, \mathrm{B}$, and $\mathrm{C}$ beds. The $\mathbf{A}$ bed, which extends upward from the pipe at the 300-foot level, is impressive because of its size and its irregularity. Its footwall appears to be a fairly constant surface striking N. $65^{\circ} \mathrm{W}$. and dipping $15^{\circ} \mathrm{N}$. The thickness stoped ranges from 1 foot to 20 feet. The ore ends abruptly against barren rock, for in places barren rock marks the limit of the ore as a wall 20 feet high or constitutes the face of a pillar. Everywhere curved carbonate lines the walls of the stopes. In this ore bed can be seen countless angular fragments of limestone cemented by brownstained curved carbonate, particularly in lean portions and along the edges of the ore body.

\section{PIOCHE-BRISTOL MINE}

The Pioche-Bristol mine, formerly known as the Cutt property, after Edward Cutt, the original owner, is on the east side of the Bristol Range about 3,000 feet north of the terminus of the Pioche Pacific Railroad at the Jackrabbit mine. It is now owned by the 
Pioche-Bristol Mining Co., incorporated in 1916 in Utah. It comprises six claims.

A vertical shaft, the collar of which is 100 feet south of the outcrop of the vein, has been sunk by the owners in doing their annual assessment work and is now 250 fect deep, but it has not reached the vein. A small gas engine is used for the hoist. There is no compressor. In recent years the mine has been worked occasionally by lessees; in 1926 it was idle.

The country rock at the mine is the Highland Peak limestone. The vein strikes N. $55^{\circ}$ E., dips $70^{\circ}$ S., and is traceable 750 feet. It is the result of a replacement of crushed limestone between fairly well-defined walls. It ranges from 6 to 15 inches in thickness and carries some galena and anglesite but chiefly massive cerusite, with a good content of silver. Just enough copper occurs in the ore to color the vein greenish. There is very little manganese in the ore. The vein is offset about 15 feet at the point where it is now being worked. East of this offset the ore pinched within 10 feet of the surface, and all the workings along that portion of the vein are shallow open pits. Immediately west of the offset the vein is holding its width so far as it has been opened, some 15 feet in depth.

\section{IUCKY STAR MINE}

The Lucky Star group of claims, or Giant group, as it is now named, is 13/4 miles northwest of Jackrabbit. It consists of eight unpatented claims. The r.hief development is a tunnel about 570 feet long, which was driven S. $20^{\circ}$ E. to undercut at a depth of 150 feet a body of manganese ore that is exposed in a small open cut on the hillside. It had not yet reached the ore in 1926. Two shallow inclines 60 feet apart were sunk at the outcrop of a lead-ore vein occurring 150 feet south of the open cut on the manganese ore.

The lead-ore vein strikes $\mathrm{N}$. $50^{\circ} \mathrm{W}$. and dips $50^{\circ}$ $\mathrm{SW}$. It occupies a normal fault in Cambrian limestone. The limestone forming the hanging-wall country rock is the Mendha limestone; it strikes N. $10^{\circ} \mathrm{W}$. and $\operatorname{dips} 25^{\circ} \mathrm{W}$. The ore is lead carbonate in a manganiferous gangue. Locally, as at the north shaft, manganese ore makes out into the country rock as far as 20 fect from the footwall of the vein. At the open cut 150 feet north of the shafts high-grade manganese ore is exposed; it is roughly 50 feet in the footwall country rock of the lead-ore vein. The ore is in part of steely appearance, owing to the abundant pyrolusite in it. In places the ore extends out into the footwall along the bedding of thinly stratified limestone which $\operatorname{dips} 5^{\circ} \mathrm{E}$.

\section{FORTUNA MINE}

The Fortuna mine is 1 mile northwest of Jackrabbit. An inclined shaft sloping $58^{\circ} \mathrm{W}$. has been sunk 40 feet on the vein, and a drift turned off at the bottom. $89276-32-6$
The country rock is a dolomite dipping $20^{\circ} \mathrm{N}$., a member of the Highland Peak limestone. The vein trends $\mathrm{N} .75^{\circ} \mathrm{W}$. It is marked by a well-defined footvall, which is polished and scored with grooves that $\operatorname{dip} 40^{\circ} \mathrm{W}$. Above the footwall the dolomite has been crushed to a breccia 6 feet or more thick, but the mineralization is lean. The country rock under the footwall is shattered through a thickness of several feet, and there appears to be no reason why ore should not make in places under the footwall. The main sulphide is galena, in places altered to cerusite. Locally a little copper stain shows. Ore on the dump contains considerable white chalky hydrozincite and a little calamine.

\section{MANHATTAN MINE}

The Manhattan mine is on the summit of the Highland Range a short distance south of Stampede Gap. In early days, when the smelter was operating at Bristol Well, the mine supplied the necessary iron flux. It is now owned by the Amalgamated Pioche Mines \& Smelter Corporation.

Company maps show an elliptical area whose axes are 2,700 feet and 3,900 feet, which is termed the iron ore body. Within this area considerable work has been done on thick gossans that have formed from the oxidation of pyritic garnet rock. The garnet rock consists largely of a coarse brown aggregate of the iron-bearing variety termed andradite. It occurs as large masses and as thick irregular veinlike bodies traversing a coarse white marble. In places there is much limonite which borders the garnet rock, having replaced the adjacent marble. It appears to have formed in part at least by the precipitation of iron derived from the oxidation of the pyrite in the garnet rock. The garnet also shows signs of alteration and has yielded some limonite or allied product.

The garnet rock is cut by a number of large quartz veins, some of which are as much as 10 feet thick. They crop out boldly and are traceable for several hundred feet.

\section{MENDHA MINE}

The Mendha mine is in the Highland Range 8 miles by road northwest of Pioche; it is at an altitude of 7,150 feet on the west flank of Arizona Peak. The mine has been worked intermittently since the seventies and is reported to have produced several thousand tons of ore. Recently a concentration plant of 50 tons daily capacity using gravity and flotation was erected at a cost of $\$ 30,000$. The mine was operated by the Union Mines Co. for about nine months during 1925 but has since been idle. It is developed chiefly by an incline 900 feet long, which descends in the plane of the vein at an angle of $30^{\circ} \mathrm{W}$. The hoist was operated by a Fairbanks-Morse single-cylinder 40-horsepower gasoline engine. 
The Mendha ore body is a replacement fissure vein striking $\mathrm{N}$. $85^{\circ} \mathrm{W}$. and dipping $75^{\circ} \mathrm{N}$. The main ore shoot pitched northward at a very low angle, steepening, however, in its lower portion to $30^{\circ} \mathrm{N}$., as measured in the plane of the vein. (See fig. 13.) On the lower levels some bedded ore that branched off from the fissure vein was found.

Light-gray dolomite beds of the Mendha limestone form the country rock that incloses the Mendha vein. They strike N. $20^{\circ} \mathrm{W}$. and dip $30^{\circ} \mathrm{N}$. The gray dolo-
In places the Mendha fissure is very insignificantfor example, the vein as seen in the roof of the incline near the 500-foot station is the merest iron-stained fissure ranging from a quarter to half an inch in thickness. Nevertheless a large body of ore was stoped upward from a point immediately above the 500-foot station. The Mendha vein is cut off on the east, 120 feet east of the incline, by a cross fault dipping $60^{\circ} \mathrm{S}$.

Considerable bedded siliceous ore has been mined on the lower levels. This ore has resulted from the

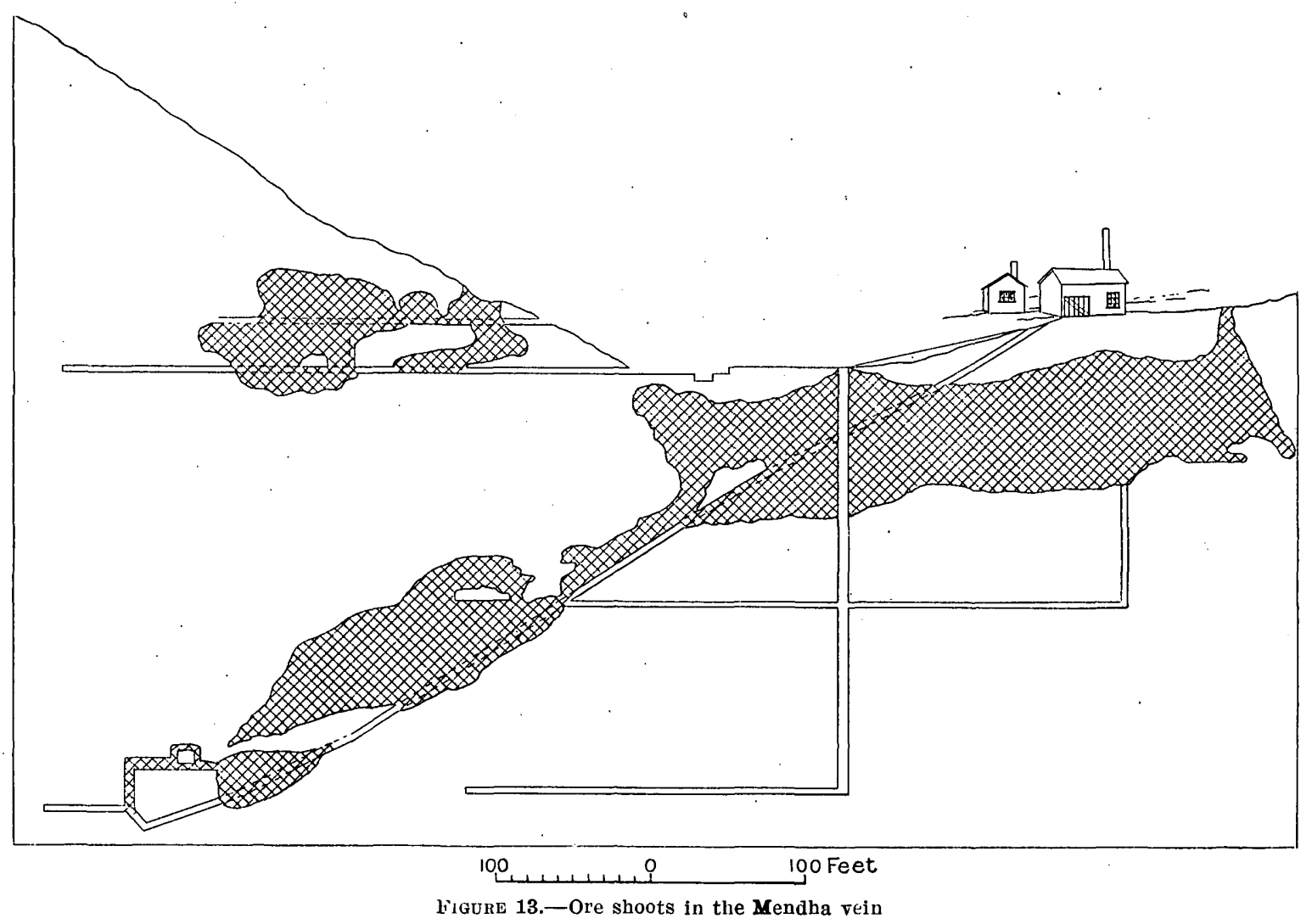

mites are overlain by blackish banded carbonate rocks, also members of the Mendha limestone, but the vein does not appear to enter these, or at any rate the fissure has been found to be unproductive in them.

There was no displacement on the Mendha fissure, as shown by the fact that the dolomite beds have not been dislocated on opposite sides of the fissure. The Mendha vein is well shown on the west side of the valley, where it has been stoped out for a thickness of 1 to 4 feet, averaging about 3 feet. There is a wellmarked sheeting in the dolomite parallel to the vein. The vein filling still remaining consists of jasperoid and red jasper carrying lead carbonate. The red jasper on oxidation yields reddish-yellow iron ocher. Ore from the deeper workings consists of coarse galena, partly oxidized to cerusite, a minor quantity of pyrite almost completely changed to limonite, and a little glassy quartz:

silicification of brecciated dolomite beds, for in places angular fragments of unreplaced dolomite can be seen in the ore beds. It was stoped out from the 700 -foot to the 900 -foot level; the stopes were mainly from 5 to 10 feet high, but the Bonanza stope, on the 700foot level, was as much as 15 feet high. Bedded ore was limited on the north by the Mendha vein, on the southeast by broken and faulted ground, and on the west by a fault.

The following assay of a lot of 24 tons of crude ore indicates the composition of the ore recently mined: Gold, 0.49 ounce to the ton; silver, 7.1 ounces to the ton; lead, 9.4 per cent; iron, 18.7 per cent; lime, 2.9 per cent; insoluble matter, 46.1 per cent.

\section{HAMBURG MINE}

The Hamburg mine is just east of the Mendha mine in the Highland Range. The surface workings con- 
sist of a trench on the vein 50 feet long and of irregular depth but nowhere exceeding 20 feet; they are about 300 feet east of the portal of the tunnel through which the mine was mainly worked. The tunnel is driven on the vein, and the ore zone was explored above and below the tunnel level by raises and winzes. Recently the mine was bought by William Franklin for delinquent taxes.

The country rock consists of light-gray and white beds of dolomite of the Mendha limestone. A glassy dike (dacite vitrophyre) rich in biotite, hornblende, and andesine crystals is shown 100 feet from the portal of the tunnel; it is about 5 feet thick and cuts transversely through the vein, though the intersection can not be seen at the present time because the workings here are inaccessible. The fresh, unaltered condition of the dike points to its postmineral origin, which was first recognized by Anderson. ${ }^{47}$

The vein strikes east and dips steeply north. 'It is narrow, probably less than a foot in thickness. The filling is chiefly limonite or red jasper and.carries lead carbonate. In places the vein matter spread laterally from the main fissure along joints, small fissures, or bedding planes, forming bunches of ore.

\section{COMET MINE}

The Comet mine is at the west base of the Highland Range, at an altitude of 6,450 feet, about 20 miles by road from Comet siding on the Pioche branch line of the Union Pacific system. It is owned by the Comet Mines Co. The property consists of nine claims and a mill site.

The mine is opened by three shafts. The main shaft (No. 3), which is 480 feet east of No. 1 , is a new vertical shaft, attaining a depth of 160 feet. From the level thus reached an incline extends down to the 480-foot or bottom level. Most of the development work and stoping has been done from the main shaft, between the 168-foot level and the surface. The power plant consists of a 60-horsepower distillate engine, which operated a compressor. The hoist is an old steam hoist which was run by compressed air. A mill was built, which was run by an 80 -horsepower gasoline engine. In addition to the usual machinery for making a lead concentrate the mill is equipped with an electromagnetic separator in order to make a tungsten concentrate. Some tungsten concentrate was made during the World War, but it was not sold. During 1926 the mine was idle, having been shut since November, 1925.

The ore body is a steeply dipping quartz vein inclosed in the Prospect Mountain quartzite. The ore is reported to assay $\$ 4$ in gold and 5.8 ounces in silver

4 Anderson, J. C., Ore deposits of the Pioche district, Nev. : Eng. anc Min. Jour., vol. 113, pp. 281-282, 1922. to the ton, 2.8 per cent of lead, and 0.32 per cent of tungsten (presumably $\mathrm{WO}_{3}$ ); its total assay value is therefore about $\$ 10$ a ton. The Prospect Mountain quartzite, which is here a thick-bedded vitreous quartzite, locally cross-bedded, dips $10^{\circ}-15^{\circ} \mathrm{E}$. and 150 feet east of the main shaft is overlain by the Pioche shale.

The vein is intermittently exposed along the surface for 500 feet; it trends N. $60^{\circ}$ E. and dips steeply rorthwest. It swells and pinches and appears not to exceed 4 feet in thickness. After it enters the Pioche shale east of the main shaft it soon pinches out completely. The ore is a porous iron-stained coarse quartz. It contains, where not too thoroughly oxidized, galena, black sphalerite, wolframite, and pyrite. A soft, unctuous yellowish ocher (plumbojarosite) is fairly common. The wolframite, which is mineralogically the most noteworthy constituent, is very unequally distributed, in places occurring as heavy aggregates of coarse tabular crystals.

\section{IYNDON MINE}

The Lyndon mine is in Lyndon Gulch, on the west side of the Highland Range. It is owned by Charles $H$. Schodde. The developments consist of openings on the outcrop of the ore, a winze 103 feet deep on the main fissure, drifts 100 feet each way on the 50 -foot level, and a tunnel that is being driven in the Pioche shale just below the Lyndon limestone is expected to cut other yet undiscovered fissures. It is reported that about 1,000 tons of ore has been shipped from this mine, most of it during the World War.

The ore bodies are bedding deposits in the Lyndon limestone, the position of which is determined by the intersection of certain beds with steep or vertical fissures striking N. $70^{\circ} \mathrm{E}$. Associated with the ore are several small, irregularly distributed black dikes of lamprophyre.

The main workings are in bedded blue Lyndon limestone 6 to 8 feet thick, which is just below the upper shale formation (Chisholm shale). The ore extends along the bedding for 25 feet on each side of the feeding fissure; very little ore occurs in the fissure. On the east the ore is limited by a fault trending N. $20^{\circ} \mathrm{E}$., with the downthrown block on the west side. The ore consists of galena occurring in pockets with more or less brownish earthy gangue. In places horn silver is found. Geologically interesting is the fact that galena occurs in the lamprophyre dikes. Some ore is also associated with the same fissure in a bed 50 feet below. Other fissures showing more or less ore can be seen to extend down into the underlying Pioche shale. Some small workings have also been opened on a limestone layer inclosed in the overlying Chisholm shale. 


\section{INDEX}

A be Lincoln mine, description of

Acknowledgments for aid.

Alpium, occurronce and churncter of

(n)

(20 58

description of .......................................................... $59-60$

Amalgnmatod Piocho Mines \& Smelter Co., properties of . ........... 49, 53-54, 56, 73

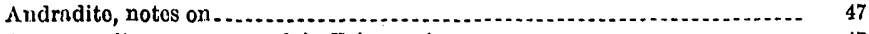

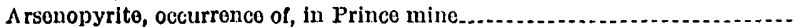

Bniloy Spring limestone, age and fossils of ...................................... 22-23 occurrence and character of thiakness of.

(30-51

Benches developed on limestone and lava ...................................

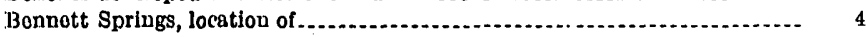

Bibliography

Big bed, description of .................. 63-64

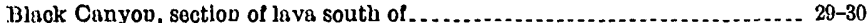
section of Mondha limestone in ...........................................

Black Motals mine. See Jackrabbit mine.

Blind Mountain aroa, contact metamorphism in............................ 37-41

intrusive rocks in

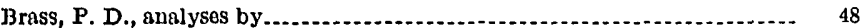

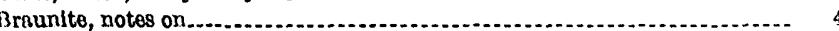

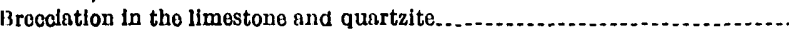

Bristol district, operations in

Bristol-Highland Range, physiography of $1-4$

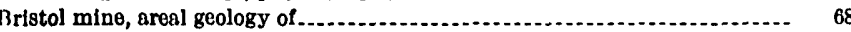

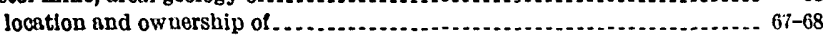

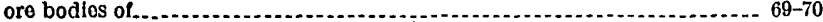

output of....................... 68

worklngs of, description of ............................................ $70-72$

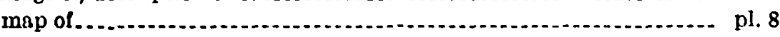

Bristol Pass limestono, occurrence, charicter, and fossils of................. 20

thickness of ................................................................ 20

Bristol Silver Mines Co., operations by ................................ 67-72

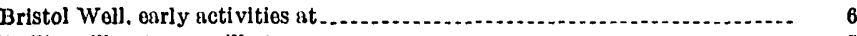

Bullionvillo, stamp mill at..

Burke mine, operations at............................................ 5, 56-57

Cambrian rocks, occurrence and character of ............................ 6-14

Camol, fossil romains of . . . .

Carboniferous rocks, occurronco and character of . . . . .

Chæpman veln, workings on ............................................... 57

Chisholm shale; ago and fossils of motnmorphism of ......................................................... oocurronce and character of............................................ 10-11

viow showing

Climnte of the district.

Columnar section of sedimontary rocks in the district................................ 7

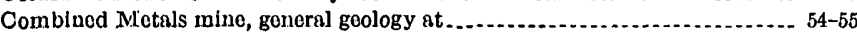

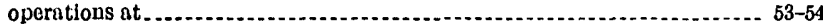
ore bodies at. ............................................... 50-51, 52,55-56

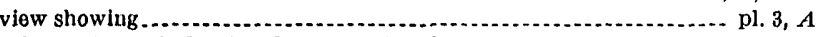

Combined Motals Reduction Co., operations by . . . . . .

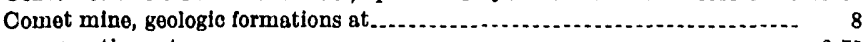
operations at . .

Condor Canyon, features of ................................................. 3-4

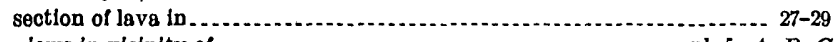
viows in vicinity of ................. pl, $A, B, C$

Contact metamorphism in the district..................................... 36-42

$\mathrm{D}$

Davldson bed, description of

Day mino. See Jackrabbit mine.

Joad Deer Canyon, section of Mendha limestone in........................

Dolmues Woll, section of lava near

Dovonian Rocks, occurrence and character of............................. 16-19
Page

Diabse, dikes of, in the Ely Range

Distomaceous tuff, occurrence of ............................................ 24-25

Dike rocks. . . ................

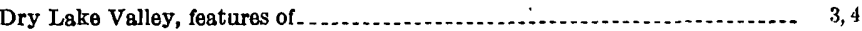

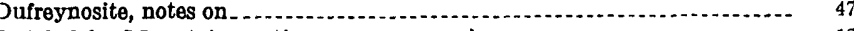

Dutch John Mountain, section on

Ely Springs, location and use of .

Ely Springs dolomite, age and fossils of..................................... 16

occurrence and character of

Springs Range, sections of lava east of

Ely Valley mine, description of ........................................... 57

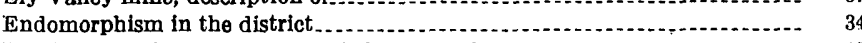

Eureka quartzite, occurrence and character of ............................ 15

Fairchild, J. G., analyses by

F

Foirview mine, description of

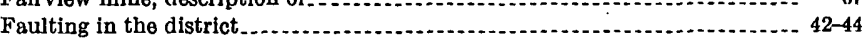

Field work

Fissure veins, features of .

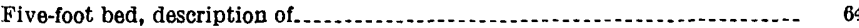

Floral spring, location and use of

Fluoborite, identification of, in the Blind Mountain area....................... 40

Fortuna mine, description of ..................................................... 73

Fourteen-foot bed, description of . . . . .

Geologic history of the district, summary of .............................. vII-vII Geologic map of the district.

Giant group of claims. See Lucky Star mine.

Girty, G. H., fossils identifled by .................................. 20, 21, 22-23

1 (in pocket)

Granite porphyry dikes, occurrence and character of $\ldots \ldots \ldots \ldots . . \ldots \ldots$

Granitic rocks, occurrence of .

Greenwood fissure, features of .......... $50,55,56$

Gypsy vein, description of .

H

Hall Moon mine, description of

Hamburg mine, description of

Hamlight Canyon, location and features of ...........

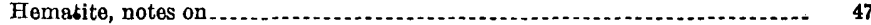

Highland district, operations in

Highland Peak, altitude of ........... 3

Highland Peak limestone, age of ............ 12-13

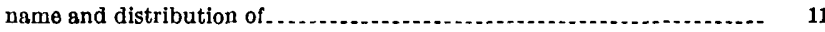

petrography of . ............... 11-12

thickness and sections of

views showing.................... $3,4, A$

Highland Range, physiography of

views of west face of........................................... $B, 4, A$

Hill, J. M., quoted......................................................... 70, 7

Hillside mine, description of

Fistory of mining in the district. .

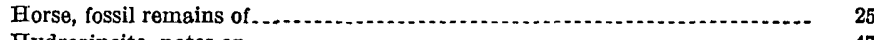

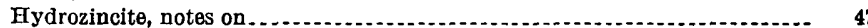

Igneous rocks, occurrence and character of

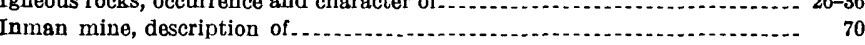

Intrusive rocks, character and occurrence of .

Iron mine, description of .................................................... 71

Iron ore in the district, origin of .

Jackrabbit district, early operations in

Jackrabbit mine, description of .............. 71-72

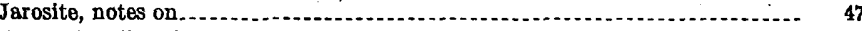

Jasperold, silver in 
Kirk, Edwin,'fossils identified by ...

Klondike Gap, section of Chisholm shale north of

Page $14,15,16,19$

Lamprophyre dikes, occurrence of

Lava, east of Ely Springs Range, sections of erosion surface on, north of Condor Canyon in Condor Canyon, section of

in northwestern part of the district

metamorphism of

of section of.

Leverrierite, notes on.

imestone, metamorphism of

Iocation of

map showing.

Lucky Star mine, description of

Lyndon Gulch, section of Pioche shale in

Lyndon limestone, occurrence and character of views showing.

Lyndon mine, description of

Mammals, fossil remains of

Manganese ore, shipments of, from Jackrabbit mine

Manhattan Gap area, contact metamorphism in

Manhattan mine, description of.

ore body at.

Mann, Albert, quoted

Msy Day vein, description of . . . .

Mazeppa vein, workings on .

Meadow Valley, fossils in .

geologic bistory of

physical features of ................................................... 3,4

view across ................ $5, D$

Meadow Valley Mining Co., operations by

Mendha limestone, age and fossils of

name and distribution of

petrographic character and thickness of ............. 13-14

Mendha mine, description of ........... early operations at

Metamorphism in the district............................................ 34, 36-42

Minerals in the ore deposits . ................. .

Mississippian and Pennsylvanian rocks, occurrence and character of . ........ 21-23

Mississippian rocks, occurrence and character of ............................ 19-21

$\mathrm{N}$

National mine, description of

Nevada Lead mine. See Fairview mine.

No. 10 mine, description of

70

0

Onondaga vein, workings on

Ordovician rocks, occurrence and character of 14

Ore deposits, general features of

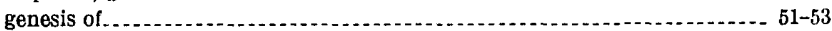

in granite prophyry

Ore produced in the district, value of.......

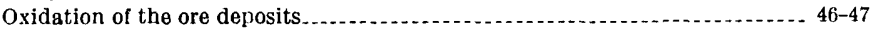

Paleozoic rocks, occurrence and character of .

Panaca, physiography of area near............... sections of rocks east of ............... 12 water supply of

Panaca formation, age and fossils of occurrence and character of views showing.

pl. $5, C, D$

Patterson Wash, features of

Peaseley Canyon, section of Fighland Peak limestone south of ............... 12 section of Lyndon limestone south of .............................. 10

Peers Spring formation, occurrence, character, and fossils of ................ 20-21

Phosgenite, occurrence of, in Prince mine .................................. 47

Physiography of the district.................................................

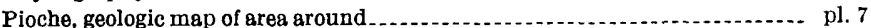
rainfall at. view of.

pl. $4, B$

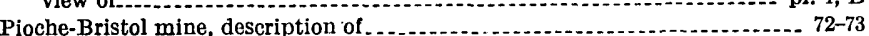

Pioche Ellls, section of Highland Peak limestone in
Pioche Mines Co., operations by ............................. 56

Pioche shale, age and fossils of

character and distribution of . . . . . .

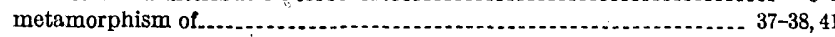
views showing.................................................. pls. $3, B, 4, A$

Pliocene (?) rocks, occurrence and character of .......................... 23-26

Plumbojarosite, notes on ...

Poorman mine, description of

Prince Consolidated Mining Co., operations by . .

Prince mine, areal geology of, map showing

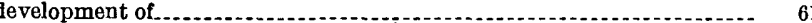

general geologic features of

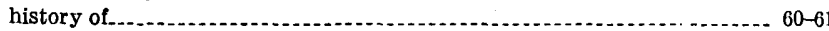

location and ow sership of

mineralogy of ore deposits of

ore beds and veins of .

output of

Prospect Mountain quartzite, age of

name and distribution of .............. $6-7$

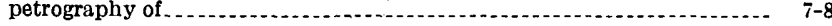

thickness of ............

Prospecting for new deposits, practicability of

Pyrargyrite, notes on

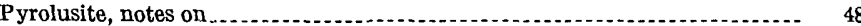

Q

Quartz monzonite, at Blind Mountain

photomicrographs of

Quartzite, silver-bearing veins in

Quaternary deposits, occurrence and character of .......................... 26

$\mathrm{R}$

Raymond \& Ely vein, geologic relations of .

workings on

Replacement ore deposits in carbonate rocks

Resser, C. E., cited .............. 14

Rhinoceros, fossil remains of ..................... 25

Rock benches :

S

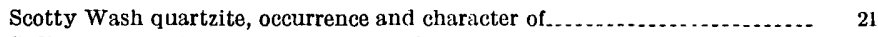

Sedimentary rocks, columnar section of ....................

description of

Siderite from Prince mine, analysis of $\ldots$

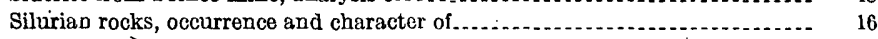

Silver-bearing ores, mode of occurrence of

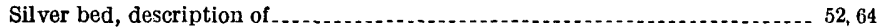

Silverhorn dolomite, age and fossils of . . character and distribution of

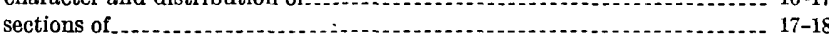

"Spaghetti" dolomite, occurrence and character of . . .................... 16-19

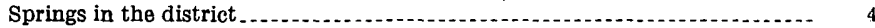
Stindt \& Donohue ore shoot, description of Structure of the district . . . .

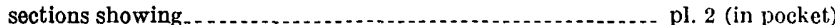

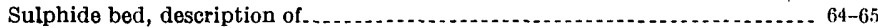

\section{$\mathbf{T}$}

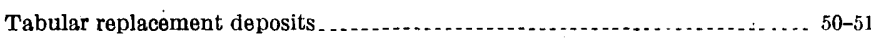

Tank Hill limestone, age and fossils of ......... occurrence and character of

Tempest mine, description of . . . . . . . . . .

Tempest vein, workings on . .

Tennantite, occurrence of, in Prince mine .

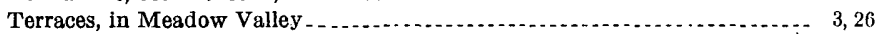

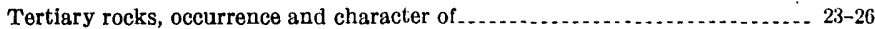

Tertiary (?) lavas, age of ............................................... 20 character and distribution of . sections of

Transportation in the district ...................................... 5,6

Treasure Hill, mines on

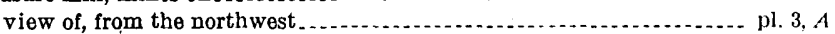

Tuff, metamorphism of occurrence and character of ................................................... 24-25

Tungsten concentrate from Comet mine............................... 75

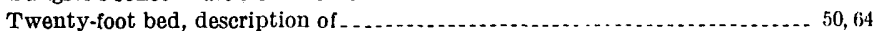

\section{$\mathrm{U}$}

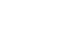

(1)




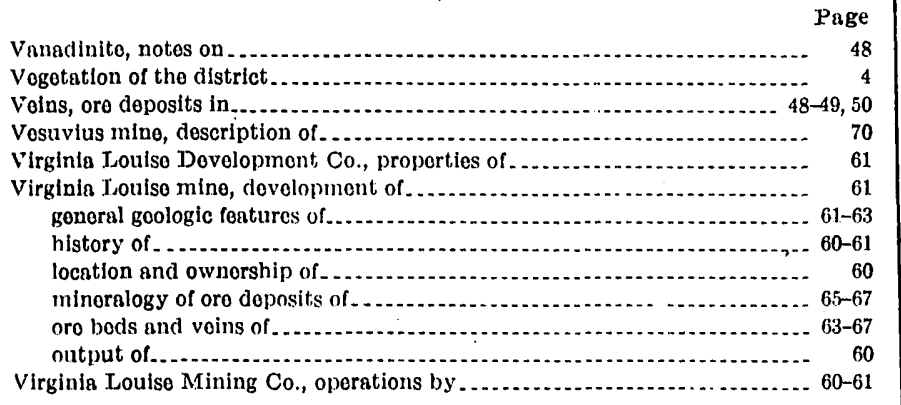

W

Walcott, C. D., cited.........................

Warm Owl Spring, location and use of $10,1_{4}^{1}$
I':ig'

Water level in the mines. ......................................... 40

Water supply of the district......................... 4

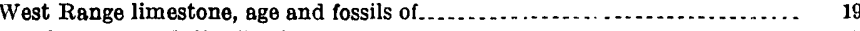

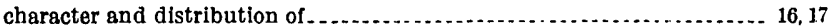

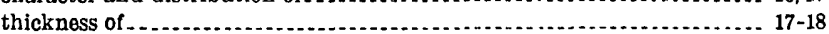

Wide Awake mine, description of

Willemite, occurrence of, on Arizona Peak ............................. 48

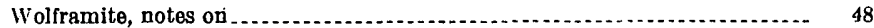

Y

Yellow Hill limestone, age and fossils of . ................................. 14

occurrence and character of ........................................ 14

Yubr dike, geology and ore deposits of . . .

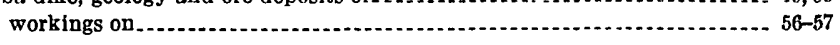

Z

Zinc bed, description of 